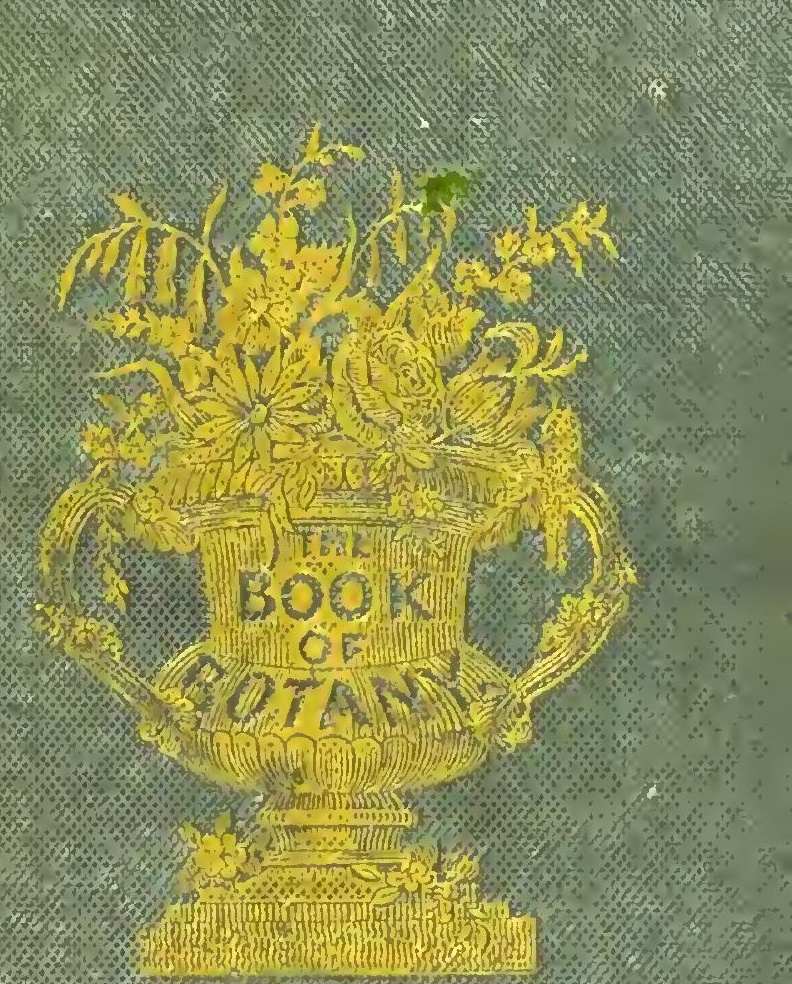

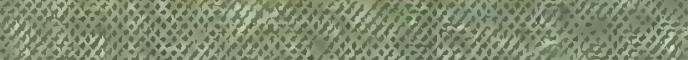




\section{The University Library}

\section{Leeds}

\section{LEEDS UNIVERSITY L}

\section{Classmark:}
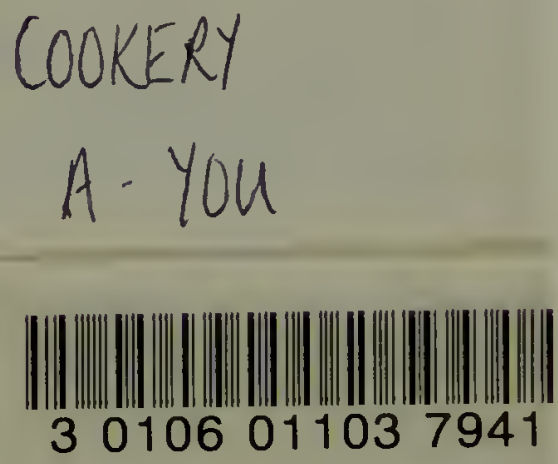



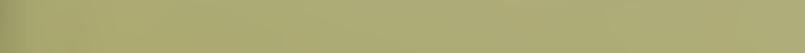




000\%er: 


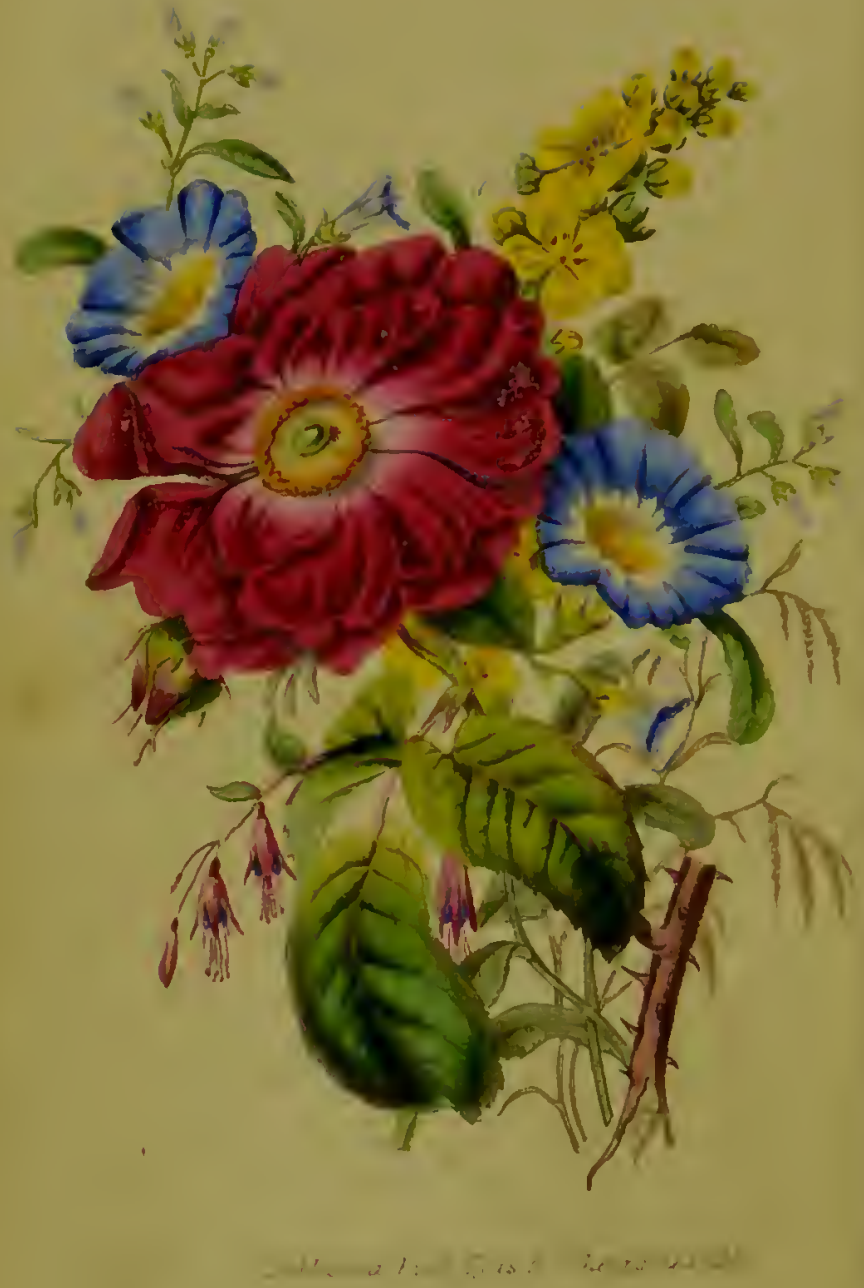


TII F

\section{Young 手adu's}

\section{BOOK OF BOTANY;}

HI $5 \mathrm{Na}$

a topUlar intTODUCTION to that

DELIGHTPUL SCIENCE.

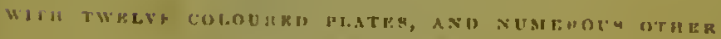

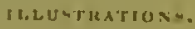

1.ONDON :

RORERT TIAS, 50, CHEAPSIDE;

J. MENZIES, FDINBURGI.

succex 
1. $98628:$

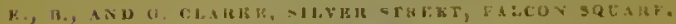

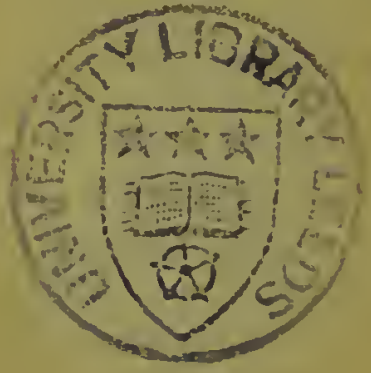

5. 15263 


\section{ADVERTISEMENT.}

Trat the mental constitution of the fair sex is sucli as to render them peculiarly susceptible of whaterer is delicate, lovely, and beautiful in nature and in art cannot, we think, be controverted; we are not therefore surprised that Botany receires more of their attention and study than any other science. The delicate forms which plants and flowers assume, the ricl liues of surpassing beauty which are so softly pencilled there by $\mathrm{Na}$. ture's hand, the odoriferous fragrance which the lowly violet, the sweet-briar, the little darling," and many otlier of Flora's favoured train, scatter around, all conspire to rencler

* Mignonette. 
is.

the science attractive and delightful. Nearly all others yield no pleasure, no gratification, until many a rugged path has been trod, until many a disheartening obstacle lias been removed,-but the votaries of Flora are met at the very threshold with every thing that can charm the eye, and gratify the sense, and at every step they meet with fiesh charms, and such an accumulation of beauty, as renders it difficult to believe that they are on other than enchanted ground; and if external forms of loveliness be so attractive, how mucl more so must those hilden processes be by which those forms "live, and grow, and have their being." The intemal structure of plants, their germination, their roots, stems, branclies, leaves, flowers, fruit, or seed, and their functions in the economy of regetable life, are some of those wonders which, while the discovery of them gratifies our thirst for knowledge, cannot fail to excite our admiration of that GrEAT 
First Cause- of that Omnipotent God whose goodness and wisdom designed, wliose power created, and whose providence directs and controls their existence for the promotion of his creatures' happiness, fitting them for those uses for which he has permitted us to discover that they are most especially adapted.

The Author has endeavoured to render this little volume as entertaining as it will be found instructive. He las sought to compress within the space allowed the most valuable portion of the immense mass of Botanical knowledge. He has described the various parts of plants, their respective func tions, and the uses to which they are applied. He has sketched an outline of the history of the science-a brief synopsis of the system of Tournefort, a full introduction of the classification of Linnacus, the "inmortal " Swede, and comprehensive yet concise accounts of the various orders of the Natural System, which seems destined 
vi. ADVERTISEMENT.

to supersede all the previous labours of scientific Botanists. T'o assist the Author's descriptions there are given nearly one hundred engravings on wood; coloured illustrations of each of the Limnaan classes, and of twenty-two Natural orders. 


\section{ISIT OF PIATES.}

FRONTISPLKCE.

Group, composed of the Damask Rose (Rosit cenli. foliu); Convolvolus minor: Fuehsia globosa; and Shepherd's Club (Verbascum).

ILUUSTATIONS OF THE LINNTSAN SYSTEN.

PL $\triangle T K \bar{F}$,

PAGE.

2 Monandria IInnogynia ........ Mare's tail

3 Diundriu Mnongynice .......... Speedwell

4 Trinnarin Monogyniu............ Croeus

148

5 Telrandiu Monngyuir................ Plantain

6 Penlandria Digynia ... ... Dwarf Gentian

7 Merandrin Monogynia ........ Wild Tulip

8 Heptundrin Monugyniu .... Winter-green

9 Octundria Ifonogynia .......... Gaurea

10 Enneandria Herugynia.... Flowering Rush

11 Decundria Digyniu ...... Carthusian Pink

12 Dorlecundriu Dodecagynin ....... Honseleck

13 Icosandric Polygyniu .......... Dog Rose

14 Polycundriu Monogynia .... ..... Rockrose

15 Didiynamin Gymnospermire ....... Foxglove

if Tritradynnmiu .............. Wallitower

17 Iunudelphia Polyandria ..... Field Mallow

is Diudelphin Octundria .. Common Milkwort

19 Polyndelphiu Polyandrin .......... Tutsan

211 Syngenesiu Superflnu... Heneh Marygold $\} 182$

21 Gynandria He.randria ......... Snake koot 
22 Monacia Pentaudria .. Love-lies-blecding 23 Diociu Tetrundria............. Mistletoe 24 Polygamin Monacin......... Wall Pellitory 193

25 Cryptogamia Heputica.... Jungermannia

ILLUSTRATIONS OF TIIE NATURAL SYSTEM.

26 Fı́.1-Alga........... Oscillatoria Urbica 2.-Fungi .............. Mushronm 3.-Lichenes........... Stereocuulon 4.-Filices....... Polypody of the Oak

27 Aroidea................ Wake Robin

28 Gruminec............ Sweet seented grass

29 Commelinacea .............. Spiderwort

30 Orchidace ............... Epiclandrum

31 Suntulace $. . . . \ldots \ldots \ldots \ldots . .$. Sandalwood 235

32 Thymelea................... Mezereon

33 Chenopodacea........... Water Starwort 34 Nyctaginere................. Marvel of Peru

35 Convolvalucea........... Field Conrolvules 269

36 Ericucea ................ (Irish) Menzi

37 Campanulacea.............. Throatwort

38 Composita ............... Mudiu Ëleguns

39 Cuprifolincea .......... Linnea borealis

40 Aruliucea ..................... Ginseng

41 Berberiducea.......... Common Barberry

4y Leguminosd ................ Field Pea

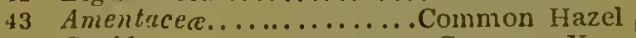

44 Conifere ............... Common Yew 


\section{THE BOOK OF BOTANY.}

DElINITION OF TIIE SCIENCE.

Asoxs the rarious branches of human knowledge, or among the sciences which clevate and enlighten the mind, and which administer to the wants and wishes of mankind, not one is more interesting, or productive of more rationil amusement ind gratification, than the science of Botiny. Its pursuit is one of innocence and unalloyed pleasure, combined with healthful exercise.

While the Astronomer must prosecute his studies under the reil of night, and the Geologist and Minerilogist ure liboriously exploring the bowels and caverns of the earth-while the Conchologist is searching the shores, or dredging the depths of the ocein, and the Entrinologist is capturing and impaling his victims in 
lengthened ranks in his culvinets-while the Cheinist is experimenting amid vapours, and dinst and ashes; and when the more useful pursuits of the Physician and Anatomist are studied among the fadted forms and defunct remains of frail mortality-the Botanist is ranging in the open salubrious air, inhaling fragrance from living beauties, which are ever rising around in the garden, as well as in every field, and in every forest.

His field of action is not confined to any spot dedicated to Flora; he may perumbulate the face of the whole earth, and take cognition of the whole vegetable kingdom. Whether he traverses the luxuriant valley, or climbs the mountain's brow; whether exploring the secluded dell,-tracing the river's side, or even searching the lake or ocean's depths-he still finds objects to arrest his attention, and claim his admiration. Should ambition and an ardent love of the science prompt him to visit distant climes, to dive into the depths of intertropical forests, or wander o'er the extensive savannahs of the western world, there he will experience renewed lelight at every step, and find new objects of beauty in every scene. When he has visited all those localities, or has stored his mind with written descriptions of them when he has examined every grade of tree, shrub, and herh, and also the lower tribes which come not under these designations- 
when he can call them by names-has learnt low they are cultivated, and can tell what regions of the earth they inhabit, -can place them in divisions according to their constitutional structure, into classes nccording to the mode of their seminal development, into subdivisions and sub-classes by the position, the presence, or absence of their floral members, and into tribes and orders by their natural affinitiesthen, but not till then, will the student acquire the title of Botanist; because all the above particulars ure comprehended in and constitute the science called ВотАNY.

While pursuing the study of plants, one cannot fail to observe that they hold a middle station between minerals and animals. Superior to the first, becnuse they are endowed witl life ; but inferior to the last as being destitute of sensation.

OF THE MeMBRaxes AxD thein structure.

The regetable frame, consisting of the various member's necessary in the economy of the plant, when reduced to $\mathrm{its}$ first elements, is found to be a combination of natural fluids, detectable by chemistry, namely, oxygen, hydrogen, and carbon, with occasionally a suall 
portion of azote; besides sonie other bodies which are commonly called foreign, such as silex, lime, dec. 'These, together, form the organized structure of the vegetable; and according as one or other predominates so are the consistence of the organs more or less woody or succulent.

OF CELLULAR TISSLE.

Every different member of the plant, from the firmest wood to the delicate curolla of the flower, is formed of cellular matter. It is the universal material of which all the parts of plants are composed, but it is subject to many modifications. The individual cells are distinct hollow spheres, when fully inflated and separated from the tissue to which they may belong; but when connected, as they usually are, with numberless others, they assume many different shapes, uccording as they are pressed on by each other. Sometimes they are adpressed against others, or depressed, compressed, or elongated, as may be determined by the direction of the growth, or as may be required to complete the member of which they are a part. This cellular material is capable of being spread into thin plates, into the integuments 
of sap-ressels or air-tubes, or drawn out into lengthened fibres which constitute the strength, tenacity, and durability of the various members. These fibres are formed by a long series of cells, united by their ends, overlapping earch other at the junction. 'They are usually ranged in bundles, the interstices being filled up by cells of another order, and whicl generally lic across the parallelism of the fibres, and during the growth are extended laterally, or transversely; to the axis of the stem.

Cellular tissue is enlarged in a very curious, and, to many observers, in a most unaccountable minner. It is visibly amplified and extended more or less in one, or, it uay be, in every direction, from day to day, or from year to year. 'Tle first risible cell is furnisleed by its own proper integument, to the outside of which are attiched an infinite number of others, so closely connected that this rast number collectively only appears as a cuticle to the first opening cell. When the first, however, is partly inflated, the next in contact, and in the direction of the growth, begins to open also, and gradually assumes the shape and size of the first. The third succeeds the second, the forrth the third, and so on, froin dily to diy, till the summer growtl is over; or from year to year, in respect of permanent members, duriug the life of the tree. Thus the cellular membranes are enlarged; the increase of their frames being 
supplied by the elemental food imbibed from the earth, or inhaled from the air, during the growth; not, however, by forming new cells, or vessels, or fibres, but only to amplify those already in existence.

The above described forms and processes can only be olsserved by powerful miscroscopes; and with the sume assistunce intercellular spaces have been observed, which either serve for the conduction of the sap, or for receptacles thereof when concreted.

OF VASCULAR TISSUE, OR MIMBRAXE.

When the cellular tissue is dirersified with longitudinal tubes, spiral vessels, intercellular openings, and woody fibres, it is said to be rascular; and this is always the state in which it is found in the stems of dicotyledonous and monocotyledonous plants, and, according to its station in or upon the stem, it is called by the different names of pith, wood, alburuun, liber, a combination of which last forms the cortical layers, or bark.

The tubes are either nir or sap vessels, and are always larger and more numerous in the inner side of each year's alburoum than in the outer side; acting apparently as a kind of pith 
to each layer of alburnum. Spiral vessels are discoverable in young shoots, but as they disappear in perfect wood, they may be only coin. inon tubes obliquely disrupted by the upward swelling and prolongation of the rigorous growth.

\section{OV THE PITH.}

This is the central menber of the stem, when present, and diflers from the others in being of a much more soft and loose texture, proportionably large when young, but annually shrivelling and becouning dry and supless as it acquires nge. It is only useful in the early stages of the growth, for it soon becomes useless in the generulity of trees, and is always the first member that decays. Hollow-stemmed plants have no pith except at the joints, or as an inside lining to the fibrous cylinder.

Or THE FIBROUS Axis, OR WOOD.

The first concentric layer of wood is called the medullary sheath, and becomes visible in the stem of the seedling tree. It is elongated 
with the pith which it surrounds, and the first thin liyer of parenchymous bark and cuticls which covers it; all three at the sume time gaining lateral expansion. At the end of the summer season the growth is arrested-the plant remaius dormant until the spring of the next year, when a second growth commences, und progresses during summer, till again arrested by the cold of antumn, or becalise the paroxysm of the seasonal growth is over; which happens to some kinds of trees long before the cold of autumn is felt.

Now, if we examine a transwerse section of the first year's growth, after the growth of the second ceases, we shall see that the pith remains nearly as at first; but that a new con. centric layer of wood, called in this stage of its existence alburnum, has been added on the outside of the medullary sheath : and, further, we may observe that a new and distinct member has, during the second year, been formed on the outside of the alburnum, and within the first parencliymous bark, which is designated by the name of liber, or second cortical lisyer.

The.like process, and additions of alburnum and liber, take place in every subsequent year as long as the tree stands; every year's growth being visibly marked both externally and internally. On the outsicte a ring is left, and remains visible, where the first reur's growth ended, and where the second cour- 
menced; but this mark is only temporary, except on jointed stems. The internal marks of the growth of every year are the layers ol wood and layers of birk, their number respectively always indicating the age of the stell.

There is, howerer, this remarkable difference, that, whereas the longitudinal components appear to be continuous in jointless stens from year to year, those of the lateral expansions, namely, the additions of wond and bark, are unconnected, and remain distinctly separate, without the interjunction of their fibrous tissues, and only united by delicate cellular matter, acting like a cement. rut in order that the layers of wood nay be bound logether, convergent partitions of dense cellular tissues (the silver grain of authors, so visible on oak panels) extend from the inner side of the birk to or towards the pitl, appearing, on a cross section of the stem, like rinys from the centre.

The longitudinal growth is a visible process, and easily understood. The different unembers which compose the shoot, to whatever length it may grow, are already formed, and lie, cluring winter, abbreviated in the bud, and are only developed by the summer growth. But the internal growth of the new alburnum and liber, being invisible processes, have perplexed many a learned head to account 
for their creation. We say creation, because many eminent men consider these members to be so; and we know that as both the alburnum and liber have ceased to live, that is, have lost all capability of being further enlarged, no dilatation of either of these can be the rndiment of the alburnum and liber of the following year; and y'et we know that these last-mentioned members must arise from between the alburnum and liber which have just lost vitality. If, therefore, we examine this narrow space, to see whether there be any separate membrane whence the next year's accretion can arise, we find nothing but in thin layer of lymph coating the outside of the alburnum. Now, in this thin jelly-like strutum, neither colour or sign of organization appears; but, notwithstanding, from what we can afterwards discover, this transparent matter is pregnant with vegetable life. For, in the grafting season (February), we find in it the matter which unites the graft with the stock; soon after this we see it protruding over to heal a wound. In May it acquires the consistence of gum, and is then called cambium; in July, evident signs of organization appear; and at the end of $\mathrm{Au}$ gust (sooner or later, according to the kind of tree), we find it perfect alburnum, replete with all the cellular, vascular, and fibrous tissues of perfect wood.

For the information of the young botanical 
student, whose attention will be naturully turned to this part of regetable physiology, it is but candid to add that this phenomenon of internal growth is accounted for in uvery different way ; namely, by usserting thit the sap itself is "organizable;" and that all the membranes of the vegetable fubric are formed of certain accumulations of the proper juices.

Both opinions are submitted to the free unbiussed judgment of the young Botanist; and as a guide to the right understanding of this particular, an estublished rule in natural history may be propounded, namely; no animal can acquire existence without parental agency; nor can any plant or part of a plant acquire its being, unless derived from a seed, or from sonie pre-existing organized part of itself.

Every recently imposed layer of wood continues to be called alburnum or sap-wood, as long us it remiins of a pale colour ; for after a certain number of years the first layers, neur the pith, become hurder and of a deeper brown hue, when it receives the name of perfect, or
heart-wood.

OF THE BAHE.

The bark is the exterior covering of the stems of plants; it is either a thin trinsparent 
film or cuticle of cellular tissue, as it appears ou the stems of herbs, or it is a thick corky case, interspersed with longitndinal fibres irregularly arranged. In some instances it is thrown off in shreds or irregular shaped pieccs, in the third or fourth year; in others it is permanent, and becornes at last of considerable thickness. It becomes thicker every year, because of the annual additions of liber imposed on its inner surface; a few of which layers act as sap conductors for some years before they become united to the old outer layers, which are dead, and no longer useful to the system.

As the new growths of wood, and liber within, are constintly pressing the previously imposed layers of bark outwards, the latter must be distencled in one way or other. In some trees it is stretched horizontally, without any external fracture; but in the generality of trees, the outside layers of bark are rent in to fissures, which increase with the age of the tree, and, opening, give room for the accretion within.

The bark, loowever, is only an excrementitious part of the plant, beciuse it is only a very few of the recently deposited lnyers of liber that are really useful. All the hard ouier layers may le stripped off without injury to the tree, and, indeed, so well is this fact ascertained, that there is no readier way of renovating the vigour of a weakly tree than by relieving it of its hard scabrous bark. 
Whaterer may be the qualities which are predominant in the juices of the tree, they are nlways found concentrated in the bark, and this appenrs to be a consecjuence of the atmospheric influences acting in unison with the vital cliemistry of the plant.

\section{OF STEMS.}

The stems of herbaceous plants are somewhat similar in their general structure to those of trees. They have an external cuticle answering to the cortical lityers, within which there is a fibrous cylinder of greater or less thickness; when very thin, the centre is hollow, when thick, the central opening is much reduced, and scarcely perceptible; or if not hollow, it is filled with a soft parenchymous pulp.

The stems of monocotyledonous trees, as the Palms for instance, have a very different structure compared with the dicotyledonous stems already described; for in these there are three distinct members, namely, pith, wood, and bark; the two last increasing outwirdly, hence they are said to be exogenous. But in inonocotyledonous stems, these three members are all mixed together, there being no distinct bark or woody cylinder, or central pith, the increase of the stem arising from the centre; hence 
such stems are called endogenous; the whole body of the stem being formed of coarse cel. lular matter connected by strong woody fibres, which extend from the crown of the roots to the exterior of the stem in an oblique direction, higher and higher according to the time of their production-the youngest reaching to the very summit of the stem, and connected with the last developed fronds, or foliar expansions. Neither in cross or longitudinal sections of these stems are there any marks in the structure to indicate annual or periodical growths, such us are so visible in the trunks of dicotyledonous trees.

The stems, aud their structure, already de. scribed, are those parts which connect the roots with the branched head. The structure of both roots and branches is similar to that of the stem, except that in the roots there is little or no pith. Between the root and the stem there is a point called the collet, which is peculiarly organized. It is the crown of the loot and the base of the tmink. In the generality of plants, ull productions below the collet are roots, and descend into the soil; and all produced abore the collet are shoots, and rise in the air. Shoots produced from the sides, whether above or nnder the surface of the ground, are called runners. 'There are, however, Inany striking exceptions to this as a rule. The roots of some trees appear to be constituted exactly like stems, being studded 
with buds, whence shoots arise through the soil, and take the nane of suckers.

OF THE TUNCYSONS OF THE DITFERENT P.IRTS OF STEMS.

The pith, from its comparative bulk, central station, and open structure, seems to be of essential service to the young stem, and every shoot subsequently produced. It is probable that its chief function is us a duct for the transmission of air and water; for if a slender shoot had not a full supply of moisture during the heats of summer it would be very likely to suffer in that warm season. The pith, therefore, having a strong attractive power for moisture, retains it like a reservoir for supplying the surronnding members.

It does not appear to be otherwise necessary to the system; because we often meet with stems which are completely deprived of pith by the depredations of insects, and yet the stem or shool exhibits no sign of weakness in consequence of the loss. It is the first member which is deserted by the vivifying principle, and, as already observed, it is certainly the first which becomes a prey to decomposition and rottenness.

Every bud which originates on the medullary sheath receives 1 small brancl of the pith into 
its centre; ind if afterwarts the bud be resolved into a shoot or branch, the pith maintains its identity and station through the whole length thereof.

OF THE TUNCTIONS OY TIL AXIS OR WOOD.

As this is chiefly formed of cellular and fibrous tissues, and constitutes by far the principal bulk of the trunk, it serves to elerate and support the branched head, and collectively is that part of the tree called timber.

It is composed not only of numerous fibres, but also of numerous tubes and vessels, ranging with the fibres, and by which the sap of the tree is conveyed from the roots to the top boughs, to all the foliage, and to every flower and fruit. The sap is always more copions in the new layers than in the older ones, forming the heart of the stem; most of all in the alburnum, and gradually less in quantity as the layers approach the centre. In the list, indeed, the sap becomes coagulated and stationary, and forms what is called perfect timber. This is the reason why the timber at the heart of a sound tree is harder, heavier, and more durable than the outside layers, which have been but recently deposited. 
OP THE SPJCIAJ USES OF THF BARK.

The bark, like the wood, is formed of distinct layers of cellular and fibrous tissues, but of a far more porous and less compact texture than wood. When it first appears on a seedling stem, it consists of a double layer; the outer one or cuticle is a very thin transparent film or web of cellular matter enclosing another layer of parenchyma of a green colour and soft consistence. It hardens by exposure to the air, and is every year thickened by additions of liber imposed on its inner surface. Each year's liber is composed of a beautiful tissue of fibres, resembling lace, the ineshes being rery imperfectly filled up with cellular matter. 'The liber' grows with the alburnum, and is separated therefiom about the month of August in every year. Several of the most recent layers of liber, like those of the wood, act organically in the system as sip conductors, until they are superseded by new luyers within, and the outer ones lcse all vitality, and are dischurged entirely, or, as has been alleady noticed, are rent into pieces by the interual growth.

The bark alppears to be the natural covering of the tree, ind, as such, it is certainly useful; because the new growths of alburnum and liber would never be so gross, nor so soon completed, if exposed to light and air, as when they grow 
in the dark. And yet it is found by practical experience that bark may become too thick, too compact and indurated; and this to such it degree, that the health of the tree is impaired, and the growth entirely stopped. Nature, however, has made provision against this species of malidy in many cases by discharging such encumbrance altogether, or by rending the entirety of the bark, als has already been adverted to.

OF THI APPENDAGES OF STEMS.

Hitherto we have been directing the student's attention to the elementary constituents of the vegetable fabric, and how these constituents are arranged, and increased, together with the purposes they answer, in the stems of plants; we come now to treat of the alppendages to the steins or trunks of trees and shrubs, to show how and whence they derive nourishment, and how they are developed in order to answer the grand purpose of their being - the prodnction of flow:ers and fruit, and the reproduction of their kind.

The most striking and necessary appendage to a plant is its roots. These fix it to the earth, and driw from thence the chief portion of the 
plant's nourishment. When a seed is laid in the soil, it swells under the mnited influences of heat, moisture, and air, mntil it bursts its integuments, and protrudes a spur-like body, which descends into the ground. This soon ejects slender fibrils from its point and sides, each of which is furnished with a kind of mouth called is spongiole, by which it imbibes from the soil either aqueons or gaseous nutriment, which passes upwards into the ascending plumula or infant stem, which at the sime time begins to rear its head in the open air.

'There is something truly wonderful in the corisideration of the opposite ends of the sime body so readlily laking opposite directions. The one aspires to full air ind light, the other flies from these and dives into the earth in quest of moistare and darkness. Not that roots dislike a moderate jortion of air, for it is absolntely necessary to their existence; citte fibrils, and inore especially their tender and sensitive spongioles, would be instantly withered by the contact of dry air. Nor are they hurt lyy the action of light upon their tender points, if these be innerged in watel.

As roots are exceedingly varied in their forms and manner of growth, botanists have assigned to them jarticular nomes descriptive of their character; hence there are fibrous, bundled, irand-like or palmated, tuberous. beaded, bul- 
bous and, aeriul roots, each of which are different in form, though all are clestined to perform the same office, namely, fixing the plant in the soil and extracting from it the food necessary for the plant's subsistence.

OF THE FIBROUS ROOT.

This is the most common of all roots; it is universally that description of root with which trees and shrubs, and a great majority of herbs

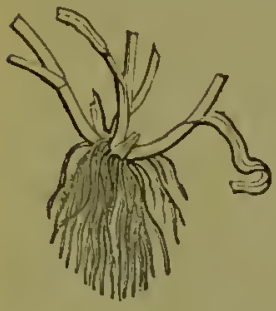

1. are furnished. It is remarkable for the number of its divisions and subdivisions, $f .1$ : the first acquire a large size, and extend to a considerible listance from the place where the tree stands; the second are only ramifications of the first, and both are invariably fringed nlong their sides, and particularly near the ends, with a multiplicity of fibrils, which ure the chief agents in the collection of the palulum of the system. The structure of the larger divisions is exactly similur to that of the trunk, except that they are nearly desti- 
tute of pith; and are increased in diumeter in the same way, that is, by annual additions of alburnum and liber. 'The bark, however, is aggregately thinner, and less compact, and from its spongy consistence, it has probably greater absorbent powers than if it were exposed to full air and light. It is observed that with every year's growth of the head a corresponding and simultuneous production of new fibrils takes place, these organs being reciprocally dependent on each other, the tubular structure of the axis forming the bond of connexion between the moving extremities. In some plants the fibrils are deciduous like the leaves, growing and fulling olf together.

The directions tatien by the latger divisions of the root diller according to their age : the first, and especially the main one, inclines directly downward; but those which are subsequently ejected take a nearly horizontal direction, ranging every year further and further from the first station, and, in many cases, keep at a very uniform depth from the surfice.

Roots appear to be attracted by moisture, or heat, or minure; and they will change their first accidentul direction to reach any of those substances or soils which are most livourable to their development. 'Their course is usually froul light to darkness; and, to approach the latter, they will take an horizontal, or even an upright clirection in a suituble medium. 
The fibrille of herbacenus perennials nre mostly annual, for though many of the fibrous processes remain from year to year, it is their active points which are renewable in the spring or at the commencement of the growing season, at whatever time of the year that may happen. For whenever there is any expansion of new foliage or stems, new fibrils must be exserted to collect the new demand of nutriment.

The main roots of atree are more permanent than the branched head; and this because they are less subject to the vicissitudes of weather, and, moleover, less liable to dnmage from wind, and accidents from cattle, insects, dec.

It lıs long been a custom among writers on Botany to consider and to call every part of a plant produced within the surface of the soil the root. Hence we have tuberous, as the po-
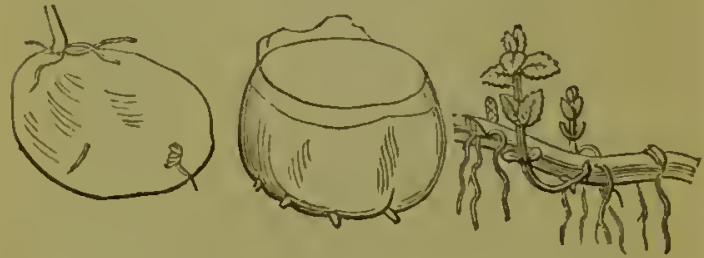

2.

3.

4.

taloe, $f .2$; and bulbons, as in scilla, $f .3$; jointed and creeping, as in mint, $f .4$; but these terms are not strictly correct; for ull 
these are, in fact, not roots, bat modified stems. In whalever form they are found, howeser, they are always accompanied and furnished with roots, which perform their proper functions of nutritive organs. The bulb of a tulip is only a large underground bud containing the proper leaves and fructification. It is a receptacle of aliment, but uttricts nothing of the kind for itself: this uflice is performed by the radical fibrils which issue from its base or radical plate, muswering to the collet of trees, and the tuberous crown of lerbaceous plants. So the tuber of the potatoe is not a root, but the thickened point of an underground stem or runner; und is nou. rished by the tult of fibrous roots at the base of the stem. So the carrot, parsnip, and beet are called rools, though, in fict, their structure shows decidedly that these are all underground steins; and their roots are the numerous fibres with which their points and sides are fringed.

In all modifications of stems, whetler they be in much-divided ramitications, as in trees and shrubs, or in the shape of bulbs, as in the onion; or in pulpy protuberances as the turnip; or in jointed lumucrs, as the water-lily (Nelumbium); or in (hose of the common concli-giass; -all ure accompanied by fibrils, which act the pitet of roots.

These working fibrils, it may be observel, 
difter considerably in size and ontward uppearance. 'Those of the tulip form a thick tuft of hair-like processes, while those of the lyacinth are thick and substantial. And though both answer the sime end, their orgatnization may be somewhat difierent. The latter, having but few fibrils, may have numerous valves or inlets along their sides for the reception of nutriment; and, this from their spongy and bibulous texture, appears the more reasonable.

The thick gouty fibrils of the hyacintli, and many liliaceous plants, are not very unlike the same class of organs produced in the open uir. We need not look among the tropical orchidacea or air plants, for examples of this description of rudical fibres; for they may be fregliently seen protruded from the branches of the grape vine, from the fig-tree, and even from those of the common May Duke cherry, if growing on a north aspect, and on a dainp border. These aerial roots are stifl and substantial, destitute of fibrous processes, and without visible inlets, and yet they inhale aliment of some kind necessary to the system.

And should we extend our view to Indian groves, where the palma and pandanacea luxuriate, or walk uuder the Banyan tig, forming

"A pillared shade with echoing walks between," 
there we should witnes's roots descending from the highest branclies and fixing themselves in the ground.

'These are the diffierent forms in which the principal food-seeking organs of plants are presented to us ; and though it be lighly probable, that plants are furnished with other organs for the induction of their elemental food, yet on the fibrils and ralies of their proper roots do they mostly depend for the necessary supplies.

OF THE BRANCHES.

The next appendages of a sten which require notice are the brunches. These originate in buds, which first appear on the last year's shoots in the axils of the leares. These buds are connected with the pith, or, at least, are seated on the medullary sheath or alburnum of the first year of the shoot's growth. This conriexion they ever mantuin, if they continue to live; and if they die, their place is always visible in the timber when cnt up for use. Some kinds of trees, especially among the conitera, are very regularly branched; every year's growth consisting of one perpendicular leader, and several lateral shoots which diverge in every 
direction from the axis. This position of branches is said to be rotate or verticillate, that is, resembling the spokes of at wheel. Sometimes branches stand in pairs, opposite to eaclı other, and alternately crossing ; in which state they are said to be decussate. The same terms are used in speaking of the position of leaves or flowers.

In general, branches are irregularly produced from the bottom to the top of the trunk; but is their number increases, they become nore and more subdivided into a multiplicity of twigs; when the growth languishes, and the tree assumes its natural stature and outline. As the branches are only divisions of the trunk, they are composed of similar members, namely, pith, wood, and bark; and the magnitude of the stem is always in proportion to the nuinber of branches it is producing, or has produced.

The mamner of branching alwaye gives a striking character to a tree. Sometimes all take an erect position as the Lombirdy poplar; or extend obliquely upward, or shoot out hor. rizontally, or hang gracefully downward; and sometimes the branches of the same tree assume all these positions; the higher aspiring, and the lower drooping. 
The stems and branches of all dicotyledonous trees and shrubs are studled with visible or incipient buds. They are of an oral figure, nore or less elonguted; and, when visible, are generally seated in the axil, or angle formed by the loot-stalk of the leaf and the stem. 13uds are lefended during winter by a series of membraneous scales, which closely cover them from the weather; which scules collectively are called the hybernaculum. Buds are the rndiments of shoots and flowers, or of both; and on dissection, all the parts which will be developed by them in the following summer may be detected in the bud before expansion.

On fruit-benring and flowering plants the fertile buds are easily distinguished from those that produce leaves only. The former are inuch larger, rounder, and begin swelling sooner than the leaf buds; and this diflerence is observable six months before their developinent.

Besides the membraneous :cales, some plants have their buds covered with a thick pubescence, or with liair; others are protected by a cout of gum or resin, secreted from anong or by the scales. These coverings are mostly deciduous when the buds burst and commence 
growing. It is said that intertropical trees have no buds, but this is only partly true.

\section{OF THE FOLIAGE.}

The next accompaniments of the stem and branches are the leives. These constitute their chief ornament and beauty. To these we owe the shady coolness and grateful shelter of trees; and the tender freshness of the newborn leaves in spriug is only equalled by the rich variety of their fading colours in autumn. The late respectable Agricultural Botanist, Mr. George Sinclair, F.L.S., called the bark of trees a "universal leaf," with a good deal of propriety, because the actual leaves appear to be only exfoliations of the cuticle and parenchymous components of the bark, notwithstanding they are articulated with it in dicotyledonous plints. The structure of leaves is very curious und beautiful; they are usually of a thin and flat figure, and are composed of (commonly) green parenchymous pulp, enclosed by upper and under cuticular webs of thin colourless cellular membrane; and connected by fibrous trachæ regularly disposed, and which have been compared to arteries and reins. The foot-stalk or petiole, when present, is continued 
to the apex directly through the middle of the leuf, und is called the costa or midrib. From this, the veins or nerves proceed towards the margin, and inosculating with each other at or near it, connect the whole leaf together in a beautifnl frame-work. 'This is the character of dicotyledonous

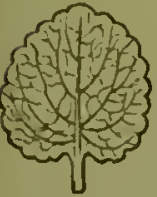

5

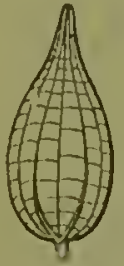

6 leaves, $f .5$; those of monocolyledonous plants are diflerently nerved; the midrib is divided at the base, and the divisions run nearly parallel with ench other to the opposite end or point of the leaf, $f .6$.

Leares are not ulways flat; those of aloes are thick and fleshy; and their green colour is, in soine instances, changed to red ol purple. Their forms itre almost infinite; Linnacus described above ninety, but that number rloes not comprise a tenth of the forms which identify or characterise the diflerent species and varieties of plants.

From the numbers, forms, ittacliments, and positions of leaves, they appear destined to act some important function in the economy of vegetable life. They have been called the lings of plants; and from their love of light, by invariably presenting their disks to the sun, the effect upon their surfaces must be productive 
of very great changes upon the fluids they con. tain. They are said to be inspiratory as well as perspiratory organs; and in their latter agency, are supposed to permit the escape of the watery purts of the sap, leaving only the richer portion to he employed in the enlargement of the plant. It appears necessary indeed that the foliage should possess a perspiratory action, to give accelerated motion to the rising current of the sap; und this may not be unreasonably assigned as their principal use in the econoing of the plant.

Other functions have been attributed to the leaves, as not only elahorating the sap into an organizable fluid, of which erery other mentber is formed, but also of preparing the qualities, and incrensing the number of fruit.

The leares of all dicotyledonous plants are deciduous either in the first, or in the second or third year. These last are called erergreens; and some of the pines and firs retain their narrow leaves for ten years or more.

The leaves of monocotyledonous herbs spring directly from the collet or radical plate; and the fronds of the trees belonging to the same class have a similar origin; their bases being permanent and collectively forming the stem of the plant, when the extremities of the fronds are witlered and fallell.

Among the numberless forms assumed by 
leares, some are exceedingly curious, of which may be particularised the pitcher plant (Nepenthes), $f .7$, the leaves of which

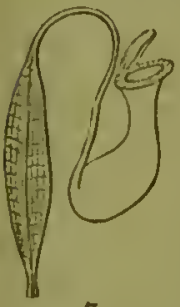

7 are lanccolate, but the point is narrow and prolonged to a consideralle distance, and at its apex bearing a hollow oblong bladder, like a pitcher, which has a neatly formed lid opening at one side by a hinge. A liquor is secreted within the pitcher of a sweetish taste; but neither the special use of the pitcher, or of its liquor, has as yet been satisfuctorily accounted for by Botanists. The leaves of the Venus' fly'-trap' (Dionaa) are also remarkablc for their form and action. The leaves are ralical, that is, they spring immcdiately from the crown of the roots, and in shape somcwhat obcordate. The midrib is prolonged beyond the blunt apex of the lenf, and bears on each side two semicircular leaflets attached to the costa by hinges. These leaflets are fringed with bristles like the teetl of a rat-trap, and when the hinge is touched by a straw or a fly, the leaflets sudicnly colapse face to face, and catch the disturbing cause in their enbrace, and, if a fly, squeeze it to death. There is another plant which has leares of a most singular contormation, namely, the $C_{e} e$ phalotus. The leaves bear cups, closed with a 
lid, which is sometimes open, and at other times shut. These cups are partly filled with a fluid; but whether condensed from the air, or secreted from the plant, is not established. It is worthy of remark that these pitcherleaved plants are inhabitants of marshy ground, where it might be supposed they would have no need of constitutional reservoirs of water in the midst of which they grow.

There is another provisional modification of leaves which nay just be noticed. 'The foliage of the Limnocharis requires to be sometimes submerged in the water in which it grows; at other times they require to be exposed to the air; when the latter exigence presses, the footstalks of the leaves become inflated like bladders, and buoy up the leaves till they float on the surface.

The sizes of leares are exceedingly rarions, differing from the breadth of a needle, to an expanse of sereral feet. The heaths are examples of very small leares; and the rhubarb, the Tussilago Pelasites, and the plaintain (Musa paradisaica) are examples of some of the largest. But the largest foliar expansion which has yet been described, is a single frond of the talipot palm of Ceylon. This enormous leaf, if leaf it can be called, measures eleven feet from the base to the apex, 
and sixteen feet across the middle; a most useful production in so warm a conntry.

Leares are variously placed with respect to each other: when placed in pairs ou the same plane, they are said to be opposite, as in the French marygold, Pl. 20; if several stand on the same plane surrounding the stem, they are sail to be verticillate, as in the common mare's tuil (hippuris vnlyaris), Pl.2; but if they stand at regular distances and consecutively on all sicles of the stem, they are then called alternate, as in birthwort (aristolochia), $P l .21$. Leaves which spring immediately from the crown of the root are culled root or radical leares, to distinguish them from those produced by the stem and branches.

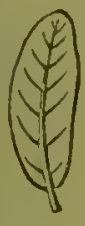

9

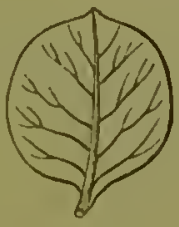

10

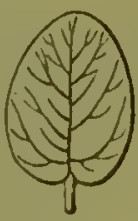

11

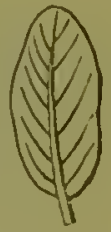

12

Leaves are either simple or compound. The most remarkable forms of simple leares are as follow:-Circular, or orbicular (orbiculutum), when equal in length and breadth, and the cir- 
cumference an even circular line; Oblong (oblongum), three or four times longer than broad-a term nsed with great latitude, f. 9; Roundish (subrotundum), approaching the orbicular form, as in the common hazel, $f .10$; Oval (ovatum), of the shape of an egg cut length wise, a very common form of leaves, $f .11$; Elliptical (ellipticum), of a similar form to the last, but of equal breadth at each end, $f .12$;

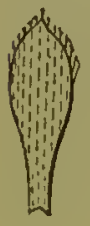

13

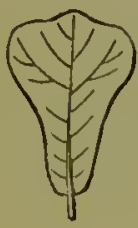

14

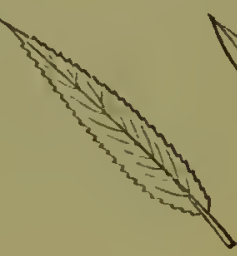

15

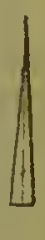

16

Spatulate (spatulatum), of a roundish figure, tapering into an oblong base $f .13$; Wedgeshaped (cuneiforme), broad and abrupt at the summit, and tapering down to the base, $f .14$; Lanceolate (lanceolatum), of a narrow oblong form, tapering towards each end, as in tulipa sylvestris, $f$. 15 ; Linear (lineare), narrow, with parullel sides, as in most grasses, $f$. 16 ; Needlesliaped (acerosum), linear, and evergreen, generally acute and rigid, as in the Fir, \&.c., $f .17$; Triangular (triangularis), having three pro- 
FOLIAGE.

minent angles, without any referenoe to their

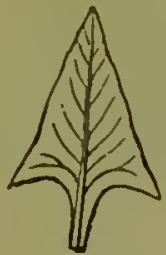

18

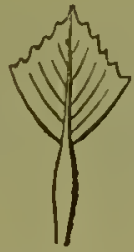

19

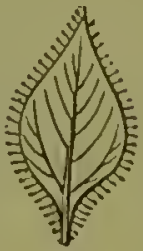

20

measurement or direction, $f .18$; Quadrangular (quadrangulare), with four angles, $f$. 19 ; Rhomboid (rhombeum), or diamond-shaped, approaching to n square, $f .20$; Kidney-shaped

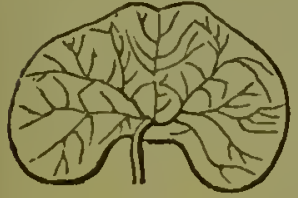

21

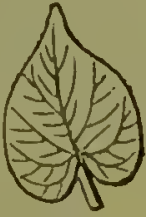

22

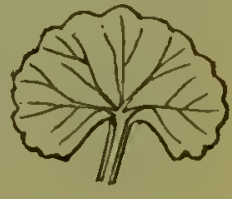

23

(reniforme), a short, broad, roundish leaf, whose base is hollowed out, $f$. 21 ; Heart-shaped (cordutum), according to the common idea of a heart-that is, ovate, hollowed out at the base, f. 22; Crescent-shaped (lunulatum), like a half-moon, whether the points are directed toก 2 
ward the stulk or from it, f. 23 ; Arrowshaped (sugittatum), triangular, very much

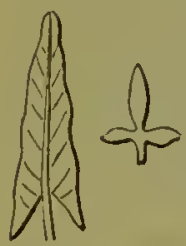

$24 \quad 25$

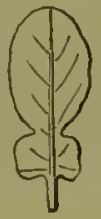

26

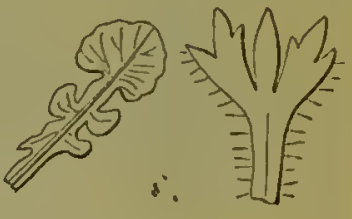

27

28

hollowed out at the base, $f .24$; Halberdshaped (hastatum), triangular, hollowed out at the base and sides, but with spreading lobes, f. 25 ; Fiddle-shaped (panduriforme), oblong, broad at the two extremities, and contracted in the centre, $f .26$; Lyrate (Iyratum), or lyreshaped, cut into several transverse segments,

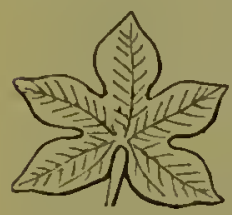

29

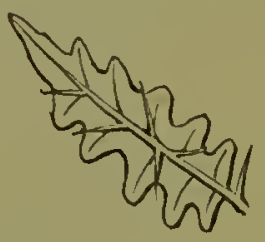

30

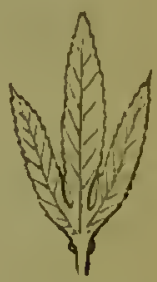

31

gradually larger towards the extremity of the leuf, which is rounded, $f .27$; Cloren (fissum), 
when the margins of the fissures and segments ure straight, $f .28$; Lobed (lobatum), when the margins of the segments are rounded, $f .29-$ they are said to be Bilobed, Trilobed, Quadrilobed, according to the number of lobes; Sinuated (sinuatum), cut into rounded or wide openings, f. 30; Partite (partitum), deeply

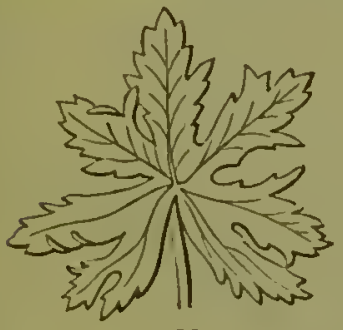

32

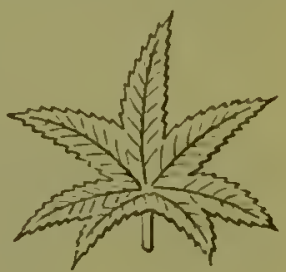

33

divided, nearly to the base-they are Bipartite, Tripartite, $f .31$, fec., according to the number of divisions; Laciniated (laciniatum), cut

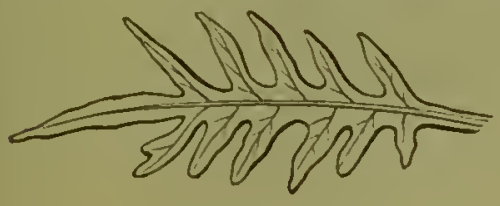

34

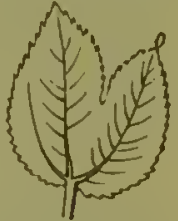

35

into numerous irregular portions, $f .32$; Palmated (palmatum), cut into several oblong 
nearly equal segments, ubout halfway, or rather more towards the base, leaving an entire space like the palm of the hand, $f$. 33 ; Pinnatifid (pinnatifidum), cut transversely into several oblong parallel segments and Pinnatipartite, $f .34$; Unequal (incquale), when the halves of the lcaf are of unequal dimensions, and their bases not parallel, $f$. 35 .

The terminations of leaves are various: they are $\Lambda$ brupt (truncatum), when the extremity is

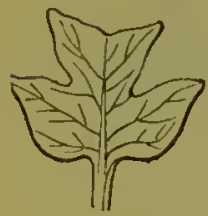

30

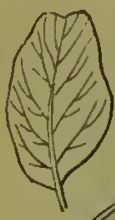

37

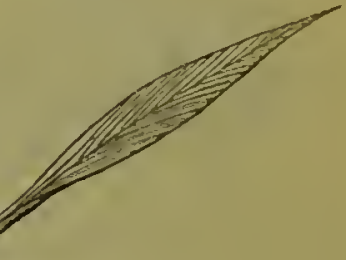

38

cut off as it were by a transwerse line, $f .36$; Retuse (retusum), ending in a broad shallow notch, f. 37 ; Blunt (obtusum), terminating in a segment of a circle, $f$. 11 ; Sharp (acutum), ending in an acute angle, which is common to a great variety of plants, as ladies' slipper, dc. $f .38$; Pointed (accuminatum), having an open or awl-shaped point, $f .22$.

The margins of leaves are described as follow: -Entire (integerrinum), as in the Orchis and 


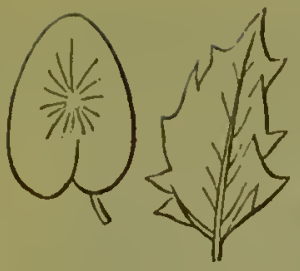

39

40

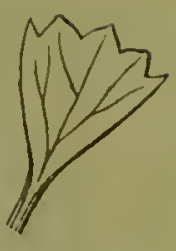

11

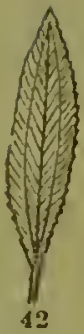

Lily tribe, $f .39$; this term cannot be applied if there be the least notch or incision; Spinous (spinosum), beset with prickles, $f .40$; Unarmed (inerme), opposed to spinous; Fringed (ciliatnm), hordered with soft parallel hairs, f. 28 ; 'loothed (dentatum), beset with projecting, horizontal, rather distant teeth of its own substance f. 41 ; Serrated (serratum), when the teeth are sharp, and resemble those of a saw, pointing towards the extremity, $f .42$; Crenate (crenatum), or notched, when the teeth are rounded and not directed towards either end of the leaf, $f .23$, as in ground ivy ; Jaged (erosum), irregularly cut or notched, especially when otherwise divided besides, f. 43 .

Compound leares consist of two or any greater number of leaflets, connected by a common foot stalk; there is the jointed leaf (folium articulatum), when one leaflet, or pair of leaflets 
grows out of the summit of unother, with $\mathrm{n}$ sort of joint. Digitate (digitatum), or fingered, when several leaflets proceed from the summit of a common footstalk. Binate (Jinalum), is a fin-
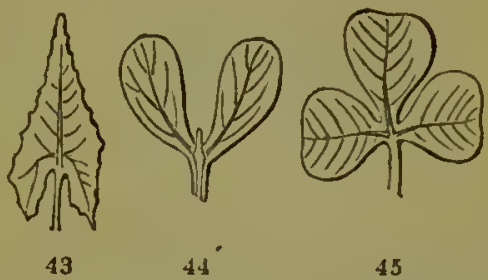

gered leaf, consisting of only two leaflets, $f .44$; Ternate (ternatum), consists of three leaflets, f. 45; Conjugate (conjugatum), or yoked, con-

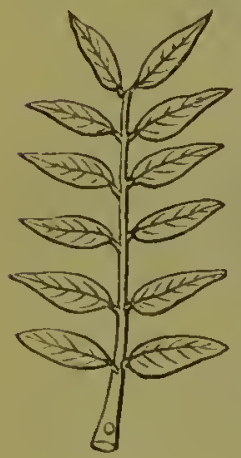

46 sists of only a pair of pinna or leaflets, und is much the same as binalum, f. 46 .

The surfice of leares is either dotted, rugged, jagged, blistery, plaited, undulated, curled, hollow, reiny, \&c.

Many of the terms used in describing leaves are occrisionally combined to express a character between the two, as ovato lanceolatum, lunceolate, inclining to orul, frc. When shape, 
or any other character, cannot be precisely defined, sub is prefixed to the term used, as subrotundum, roundish, dec., \&c. By the judicious use of these means all necessury perspicuity and precision are obtained.

Before leaving the subject of leaves it may be proper to mention a distinction made by Botanists, between what are considered real lenves, and other foliar expansions, which man be mistaken for then. The minutely elegant green expansions of ferns, and the stupendous leaflike productions of palus, not being articulated with the stems, and therefore in this respect decidedly different from dicotyledonous leaves, ure called fronds, $P l .26, f .4$. Linn xus applied this term to the leares of palms and ferns ; but it is also employed in describing the proper expillsions of stemless and leafless plants, as the algee, fungi, and some of the hepatica. It is, lowever, considered that it wonld be more correct to call the fronds of palms and ferns radical leaves, which, in fuct, they really are, and alply the term frond to those fanilies which chmot be said to have any leaves.

The insertion of leaves is another circum. stince noticed in describing plunts : they are radicil or caulinar. In either case, they are said to be petiolute, $f .47$, supported on footstilks; or sessile, that is, setting close to the crown of the roots, or stem, $f .49$; or vaginunt, $f .48$, that is, sheathing the stem, as in grasses; or amplexicaule, $f .49$, stem-clasping, as in many 


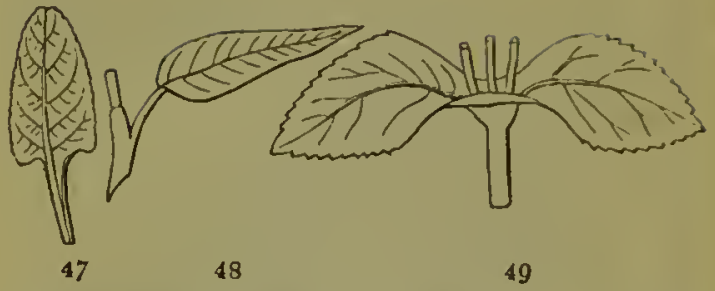

umbelliferous plants; or connate, that is, situate opposite each other, and united at the base, as in the leaves of the common honeysuckle. In clothier's l,rush (dipsacus), the leaves are so united as to form a deep cup retentive of rain, for the supply of the plant ; or leaves are decurrent, that is, running down the stem to a point considerably below the place where they diverge from the stem.

\section{OF THE STIPULA.}

Next to the proper leares, another order of what may be called leaflets is to be noticed. In a very great number of plants, the proper leaves are nccompanied by two very thin and pointed expansions, called stipules, $f$. 50, one on each 
side of the petiole, and are either united or distinct from it. In some of the grasses the

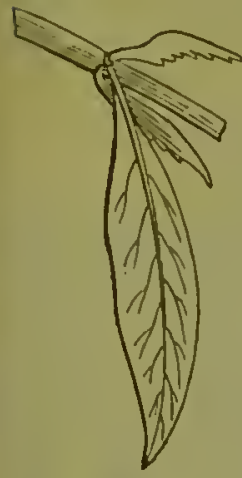

50 stipula is single, und invests the stulk above the diverging limb of the leaf. This description of stipulx is exemplified in some of the grasses, and in the bistort, or buck-wheat (polygonum). In the fig-tree it invests the point of the shoot, and is burst off by the swelling of the bud within. In many plants, the stipula drop almost as soon as the leares begin to expand; but in many cases they full with the leaf. In pinnated, that is, winged leaves, there are often two stipulie at the base of each leaffet as well as at the base of the common petiole: "stipula under such circumstances are called stipellæ." - Linne.

Stipules are, (especially those which are cotemporary with the leaves) a kind of accessary leaves, and probably are endowed with similur functions. They are sometimes not eilsily dis. tinguished from certain membranous expansions or cilic (eye lashes), or glandular appendages of the margin of the base of the petiole, such as are found in umbellifera, and many other plants. When stipule are attached to, or ac- 
company, the petiole of opposite leaves, their adjacent inargins unite and form a cup round the stem. In this state they become what is called an ochreu.

OF BIACTEA.

The bractea are a leaf-like production usually placed between the proper leares of the plant and the flower.

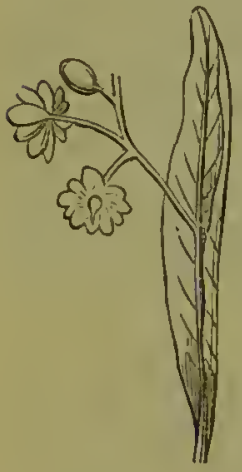

51

They are often very diflerent from the common leaves, as well in shape as in consistence and colour; when very small, they ure called bracteola; but sometimes they are of considerable size and also numerous. They are particularly conspicuous and persisting on the peduncles of the common lime tree, f. 5l, (Tilia). The cups of the acorn are endurated bractex; and the leafy envelope of the common hazel-nut is an appendage of the same character.

Plants which present their flowers in spikes have almost always bractex accompanying each flower, as in some of the hardy orchiducea ; in the primrose and medlur they resemble the 
common leaves, and in eucomis the bractex are on the top of the stem above the flowers.

On umbelliferous plants the bracter, which surround the general umbel, are called an universal involucrum, $a$, and those which sur-

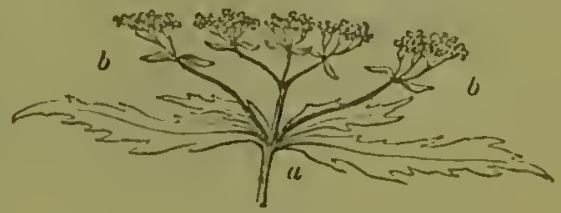

round the divisions of the umbel are called involucellum, $f .52, b . b$.

It sometimes happens that the common leares at the bottom of a stem are gradually diminished as they approach the terminal flowers on the summit. In this case the leaves are ultimately resolved into bractere; nor is it easy to point out where the leaves end and the bracter begin. Their relationship to leaves is particularly manifest in the circumstance of buds being sometimes found in their axils; and, however they may be riewed, their character as accessury leaves becomes perfectly obvious. - Lind.

Another and very conspicuous member always attending the flowers is denominated a spathe; it is that membrunous envelope which involves the flowers of nurcissus, snow-drop, nrum, $P l .27 \cdot a$, and the spadix of palms. This, 
though different in texture, and in its special oflice, is notwithstanding considered by many Botaniste as only a modification of bractea.

We are now rapidly approaching the floral members of the plant, but before entering upon the description of them, it may be proper at this stage of our investigation, to notice some other appendages of the stems, or of other parts already mentioned, and which cannot escape the observation of every lover of plants. The first of these to be noticed is-

\section{THE TENDRIL.}

This member in the language of Botany is called the cirrhus, $f .53$; or, in common language, a clasper. It is a tough string, produced by some plants which are naturally climbers, but whose stens are so feeble that they require support from any other bodies within their reach. Tendrils are produced by, and proceed from, different parts of plants ; from the points of the leaves as in the superb lily (Gloriosa), and the common pea and retch (Pisum et Vicia). In the grape-vine and Virginian creeper (Ampelopsis), the tendrils are produced from the shoot opposite the leaves; in the passion flower they are axillary; in the cucumber, from the slioot by the side of the petiole of the leares. Iendril-like processes 


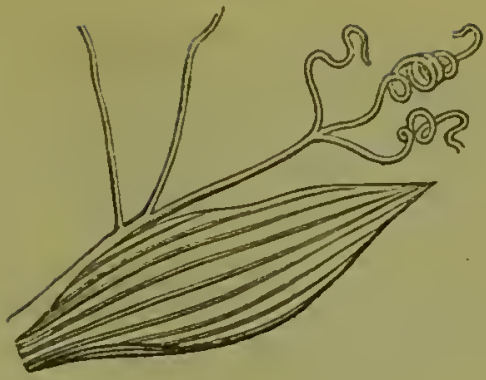

53

are produced from the bark of the ivy and of the trumpet flower(Bignonia), and though these have no convolving power, they have little flattened points by which they firmly attach themselves to the bark of trees, or to the surface of walls. The virgin's bower (clematis) has no proper tendrils; but the footstalks of the leaves have a convolving power, by which they twist round any other slender body for snpport.

Many tendrils have a most unaccountable mode of convolution; they turn towards the right for about half their length, and if they get loold, continue in that direction; but if they miss a hold, the tendril hegins turning backwards the contrary way to make a second trial for sipport. In the evolutions of vegetation, we may have some satisfuctory ideas as to the ascent of a plant in the open air, or of the de- 
scent of its roots into the earth; but of the fibrous structure of a tendril which has such contrary tendencies we can have no collception; and therefore can only attribute the phenomenon to a law of nature impressed upon this slender member by the Almighty Designer himself.

'Tendrils are generally simple, but therc are several instances of their being compound and branched; the petiole of the pea is prolonged bcyond the pinnx of the compound leares, and branched at the point. The tendrils of the grape-vine bear the flowers, which if fertile, no convolution of the stalk of the bunch takes place; but if barren, it soon begins to curl and assume the office of a clasper. It is only a fcw of the tendrils at the bottom of each sirong well-ripened shoot of a vine that arc fertile, all the rest above are naked and barren.

Other processes are called the armature, because they serve to defend the plants from browsing animals. Those are spines, prickles, and stings.

\section{OF THE SPINES.}

The spines (spince), f.54, or thorns of plants, are sharp pointed woody processes issuing from the alburnum of the stem and other pirts of 
the plant. They are produced on the shoots of

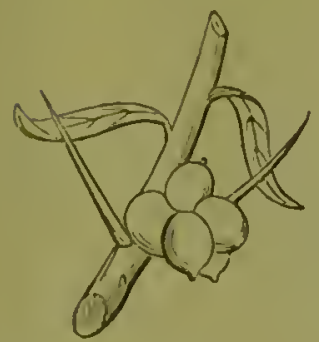

54 the hawthorn ; from the lenves, as in holly; from the petiole of some compound leaves, as in astragalus; from the anthodium, us in the thistle (Carduns); from the seed ressel, as in stramonium; or fronl the seed, as in spinach.

Many plants which are spiney in a wild state lose their spines when cultivnted; and many which are well armed, when young and low, lose their armature when aged, or when out of reach of cattle. The crab-apple and hawthorn are striking instances of this loss of armature ; and is accounted for by suying that, when the rigorons growth of youth is subdued, the system is unahle to produce any kind of superfluous
member.

or Priclilis. Prickles (aculii) $f .5 i$, differ from spines, in
being produced from the bark and not from the
E 


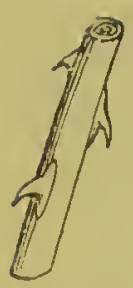

55

wood. They are exemplified in the rose and gooseberry; und in these plants they are articulated with the bark, and frequently deciduous. In sume instances, the bractere become prickles, as is observable in the berberry; a change which appears to be a consequence of luxuriant growth.

\section{OF STINGS.}

Stings (stimuli) inay be considered as only a minor order of prickles; there is this difference lowerer, that besides puncturing the skin, they emit at the same time an irritating juice into the wound, causing inflamation and pain. The common nettle (Urtica) is the most familiar example; and there are many other plants which are furnished with a similar defence.

There are many tropical plants, especially among the cactea, which are profusely covered with horrid spines and prickles; these plants being mostly destitute of foliage, it is probable thit these numerons keen-pointed processes act tlee part of leaves, either in discharging super- 
ftuous fluids, or attracting necessary gaseous aliment for the use of the plant.

OF PUBESCLXCE.

Under this head Botanists include all descriptions of hairiness found on plants; but as such coverings difler from the rigidity of bristles to the smooth softness of relvet, many terms are employed to describe the character of each.

We are apt to adnire the fine fur, the beautiful fenthers, and curious scales of animals ; but none of these can be compared with the delicacy, the softness, smoothness, and exquisite structure and arrangement of this clothing of plants. On some leares, or other parts of plants, it is like a soft down (pubescens), or hairy (hirsutus), or like pile (pilosus). Sometimes it is long and soft (villosus); or it is short and close, like velvet (velutinus); again in other instances, it is close and entangled (tomentosus), or standing ont like eye-lashes (ciliatus), or like bristles (setosus), or as hooks (rostella), or bearded, if split at the point (glochidatus), or if the pubescence resembles cobwebs, it is said to be arachnoid.

'The structure of these various slender bodies can only be detected by the assistance of the 
microscope: they appear to be formed of one or more cells of cellular tissue placed end to end arranged in runks or dispersedly disposed. They are mostly conical; but they are also jointed, and sometimes they are fixed by the middle, their points standing out in opposite directions. In many cases the hairs grow in clusters; and this disposition is also observable in the case of both spines and prickles.

But it would be a long and laborious task to describe all the different forms in which this curious clothing of the surfaces of plants may be seen; and if the investigation of the forms only be difficult, how much more difficult is it for us to assign to these minute and slender organs their special use in the economy of the plant? That they answer some specific purpose connected with the vital chemistry of the system; or are protective, or nutritive appendicates of the same, may be safely aflirmed; but this is only specious guessing; as their agency, whatever it may be, is too attenuated and inconceivable to our keenest perceptions.

OF SCALES.

There are many distinct members of plants, which because they resemble the scules of fishes 
aro also called soales; and as they are often disposed in the same manner, the name is the more appropriate. They are usually thin and membrinaceous, and appearing to spring from the cuticle. Where tliey exist in considerable numbers, they give a white leprous hue to the stems or leaves on which they are seated. The leaves of the pine-ilpple (Ananusea), prisent this appearance, and which is solely owing to the great number of mintite scales which invest their surface. These scales are supposed to be hairs unler anotlier form, and to liave agencies of a similar nature. Leaves so covered are said to be lepidotus.

Scales of another character and much larger size are frequently seen on the stems of plants. Those composing the hybernaclum, or bractea of buds itready inentioned, may be considered as one description of them; and the thin brown scales, sometimes in great ubundance on young sliouts of the Frencli taniarix, and on the backs of the leaves of ferns, are another example of those scales called by Botanists ramenta. Scales of another character are seen on the stems of the bird's-nest orclis (Neottia), and of the broomrape (Orobanche); but these are supposed to be only modifications of leares. 
OT OLANDS.

Vegetable glands arc little prominent bodies, appearing on diflerent parts. Sometimes they are raised on footstalks, and secrete a juice or fluid, the quality or nature of which has not been ascertained. Glands have been minutely described and classified by specific terms: among which the following are of most frequent occurrence, namely, the miliary; the vesicular; the scaly; the globular; the lenticulur; and the cupshape; the last very conspicuous on the petiole of the peach-tree and passion-flower. The vesicular glands are frequent on the young shoots of the vine; and the surface of the iceplant is covered with those called papilla, and give it a crystalline appearance. The satiny surface of the petals of many flowers, is caused by the presence of numerous papilla. The lenticular glands are the brown spots found on the bark of willows and other plants; and it is the opinion of M. De Candolle that, they not only indicate where roots would be produced if the brauch were placed in the soil, but that they bear the same relation to roots that buds bear to young shoots.

An inferior order of glands are called warts (veruca), and are common on the leaves of the tongue aloes, and on the stems of some plants, as in euonymus verrucosus. They are 
not very well distinguished from glands; but when they occur on the surface of leaves, the latter are said to be scabrous.

\section{OF STOMATA.}

A name given by Botanists to small apertures which they have, by optical assistance seen, or thought they have seen, in the cuticle of the leaves and other parts of plants. There is great difference of opinion concerning these stoniata; some aflirming thit they are really open, and are connected with the respiration of the plant, while others maintain that they are imperlorate, and consequently are not passages for any fluid. All, however, admit that they are depressions, and surrounded by a raised rion of one shape or other; and if they have any organic nction, they appear to be only useful in air, as they are never seen on submersed plants, nor on the roots. 'They are only objects of microscopic research, as they are too small to be seen by the naked eye. But at the same time, they evince the wonderfnl complication of parts required in the fabric of the humblest weed, and consummate skill employed in their creation. 
OP SCARS.

There are no natural scars upon a plant, except those from which leaves or fruit have fallen; the former are called cicatricula, ind the latter may not be improperly named, if called the cicatricula of the fruit.

In the preceding sections we have noticed all the appendages and fentures of stems, from the branches up to the scars left by fallen leares and fruit; we come now to the more interesting organs of the vegetable being, and to which all the before-described parts are, in one way or another, subservient; namely, the flowers and fruit. The flowers an'e composed of various distinct parts, each having proper functions and stations, and which may be treated of in the order of their development, - but first-

OF THE STATIONS OF FLOWERS.

Flowers are variously placed on plants ; sometimes they occupy the very centre of the plant, ex. pine-apple, or of the division of the plantor of the stem or shoot producing them, ex. pear. Such flowers are suid to be terminal; not only because they stand on the point of a 
braneh, but because this braneh or shoot is at this point arrested in its upward eareer of growth, and its lurther elongation terminated. In other cases, the flowers are produced laterally, that is, produced from the axils of the leaves, as in the eaper-tree and inyrtle; from the nodes or joints of the young shoots, as the grape-vine; or from the bark, as in the Judas tree (Cercis), and the metrosideros floribunda.

\section{OP THE ARRANGEMENT OF TLOWCHS.}

The arrangement of flowers upon a braneh or stem is either solitary, as in the diosma uniflora and tulip; or aggregated, as in the plintain and grape-hyaeinth. Eneh flower is either sessile, that is, selting elose upon the branch, or borne on a footstalk ealled a peduncle. These peduncles differ from the other parts of the branch hy being destitute of leaves; or, if they are furnished with any foliur expansion, it is a braetea not a leif. The perluncle is eitler simple, as that of a cherry, or divided, as that of the laurestine: its smaller ramifieations are ealled pedicels.

In plants which have no branched stem, sueh as the narcissus or aurieula, the pedunele rises directly from the bulb or erown of the root, 
bearing the flower or flowers on the top. Such a peduncle is called a scape; but if it proceeds from a lateral division of the crown, it is called n rudical peduncle.

When a peduncle is lengthened out in at straight or slightly zigzag line, as in the flowers of grasses, it is called Arachis or axis of the inflorescence. But when this is depressed into a flattened body, and bearing the flowers or florets on its upper surface, it is culled the receytacle, and this is differently named, according as it is or is not fleshy, or surrounded by an involucrum.

Every different mode of arrangement of the inflorescence has receired characteristic titles, and which are particularly useful in descriptive Botany. Hence there is the spike f. 56, ex-

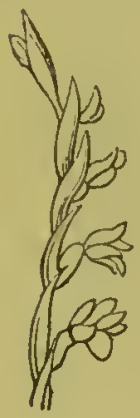

56

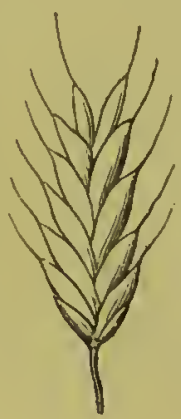

57 emplified in the flowers of the common ladies' tresses (Neottia), and its distinction is, that the flowers sit close upon the axis without pedicels; whereas, if the flowers were on pedicels, the inflorescence would then be a raceme.

When the flowers of a spike have neither calyx nor corolla, and when the whole is de- 
ciduous after flowering, it is called a catkin (amentum), as exemplified in the male flowers of the willow and hazel, $P l$. 43 ; hut if a spike consists of flowers destitute of calyx and corolla, and their place is occupied by bractex, and which does not full off with the flowers, then in such case the spike is called spicula, $f .57$, and is constantly exhibited in the grasses.

When the flowers are closely set round a fleshy rachis, and inclosed in the kind of bracterc called a spatha, the whole is called a spadix, $P l .27$, and is exemplified in the common aruns und palms.

When the raceme is composed of flowers having pedicels of unequal length, the lower flowers rising as high as the upper ones, and with then forming an horizontal pline, a style of flowering called a corymbus, $f .58$, is then formed.

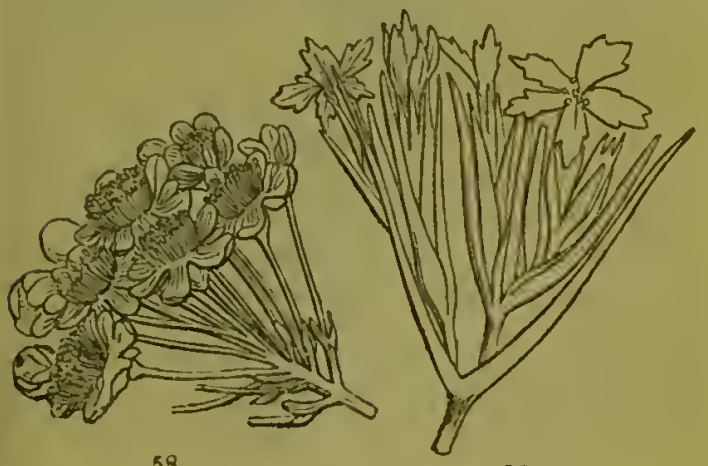

58 
If in the expansion of a corymbus, the central flowers are highest, those on the outside being lower, a form called a fasiculus, $f$. 59, or bundle, is the result, this obtains in the Carthusian pink, and is sometimes described as a compound corymbus.

When the pedicels all proceed from a single point and are of equal length, or corymbose, in umbel, $f .60$, is the character. If each pedicel bears a single flower, it is called simple; but if they divide, and bear other umbels, it is said to be compound.

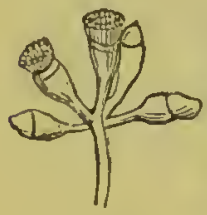

60

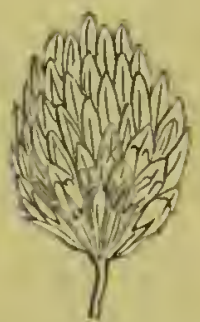

61

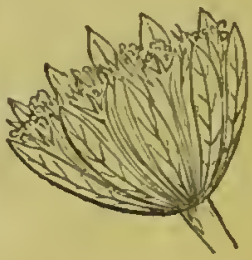

62

If the pedicels of a simple umbel be wanting, and the flowers be seated on a receptacle or enlarged axis, they collectively form a head capitulum, $f .61$. If this be depressed in form, and surrounded by an involucrum, the coinposite flower is produced and styled an anthodium, f. 62. Florets cover the disk of the anthodium; those in the circumference are legulate, 
that is, a principal part of the corolla is formed like a strap, and project outwardly like rays; and are called fiorets of the ray ; the others, which occupy the central space of the anthodium, are called florets of the disk.

Another form of the inflorescence is what is called a panicle, $f .63$; this diflers from the

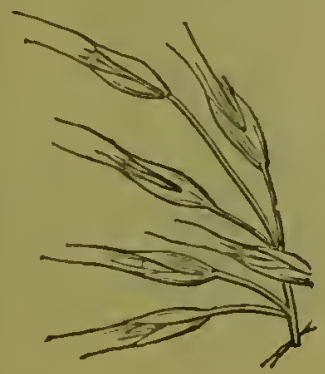

63

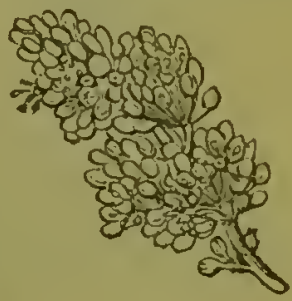

64

raceme in that the latter bears single flowers on its pedicels, whereas the former bears branches of flowers, and is exemplified in many of the grasses. But if the panicle be very dense, and the lower and highest pedicels be shorter than those of the middle, then the assemblage of flowers is called a thyrsus, $f .64$. Another modifical tion of such aggregations of flowers is called a cyme, $f .65$, of which good examples are afiorded by the heads of flowers of the elder, and the dogwood. And when clusters of labiate flowers 

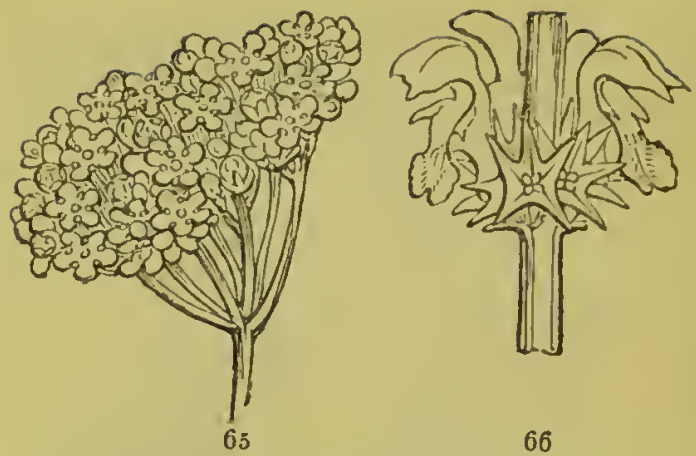

are produced from the axils of opposite leaves, and almost embracing the stem, they are said to stand in a verticillus, $f$. 66 , or whirl.

Having noticed the parts of the plant, from which the flowers are produced, and the manner in which they are borne by their peduncles, pedicels, scapes, \&c., together with their modes of appearance, dispersedly or associated, we now come to the floral members, which may be noticed seriatim; and first-

\section{OF THE CALYX.}

The calyx, or outer cup of the flower, is the most exterior integument, consisting of 
several leares in "whirl, either united wholly, or partly by their margins, or distinct; usually of a green colour, and more substantial and rigid than the corolla. These two organs, however, are in some instances so indistinct, and slide so gradually into each other, that their. positive identity becomes a matter of uncertainty. This occurs when both the calyx and corolla consist of "great many parts resembling each other, and when both partake of the same colour where they meet. The flowers of calycanthus and the mymphrea aflord instances of gridual change in the sepals of the calyx, to a resemblance of the petals of the corolla.

The best rule, as luid down in the modern schools of Botany, is to consider the first outer whirl of integuments within the bruclea to be the culyx; and whether that be deciduons, or highly coloured, or membrunous, or fleshy. Upon this principle, says Professor Lindley, whenever there is only one series of floral integuments, that series is the calyx. A calyx, therefore, can exist without a corolla; but a coro!la cannot exist without a calyx.

The calyx is therefore almost always visible, even although reduced to the dimensions of " membraneous ring. Jussieu has sild that the calyx is in all cases easily detected, because it is a continuation of the onter bark or cuticle of the peduncle. This definition is useful us a general rule; but there are some exceptions; 
as, when it is deciduous, this continuity is broken, and therefore Jussien's definition is objectionable. T'o common observers, the ca. lyx is always sufficiently manifest, as being the outer green member, enveloping the flower before expansion. But there are cases in which the knowledge of the practical and scientific Botanist is required to identify the calyx, because it is sometimes united with, or takes the exact resemblance and colouring of the corolla. One of the most simple of all flowers in its conformation is the tulip; many former Botanists hare considered it as being destitute of a calyx; but by the above rule, the three outer floral leaves must be considered calyx, and the three inner ones corolla. The flowers of the common mezerion appear, to the untaught eye, to be also destitute of calyx; but the fact is, that this plant, together with all others belonging to the same subdivision, have the calyx and corolla united.

The divisions of a calyx are called its sepals; they are generally longer than the corolla in ostivation, that is, while the flower bud is unopened, but inuch shorter afterward. If the calyx be deciduons it separates at the base; sometimes the sepals drop individually, but at other times they cohere together, and, parting at the base, are thrown off by the growth of the stamens like a cap; in such cases the calyx is sajd to be operculate. 
The calyx of composite flowers, such as the daisy, dandelion, and dahlia, is so very diflerent from the calyx of other plants, that it is known by the name of pappus or doun. It is sessile or pedicled, simple or branched; and belongs to the individual florets of the composite flowers, although, from its very situation in the centre of the disk, it is not easy for a tyro to account for such a change of place. It is, however, a conventional rule to consider the hair-like processes borne on the apex of the ovarium of these florets a calyx.

If the calyx be distinct from the orarium or seed ressel, it is snid to be inferior or lree; but if it be firmly attached to the sides of the ovarium, it is then culled superior.

When the sepals are united into a kind of cup, the calyx is said to be monophyllus, that is, consisting of one leaf; but such a state of a calyx has never yet been seen, although the sepals are often found united by their contiguous edges. Sometimes the calyx is ornamented with glands, or hair, or other lescription of pubescence, and azain hy dilatations of its cuticle. These are called appendages; and when such a culyx is described, it is said to be ap. pendiculute.

The calyx is divided into seven kinds; - the calyx, properly so called (perianthum), f.67, when it is contignous to and makes part of the flower. The involucre (involucrum), f.52, 


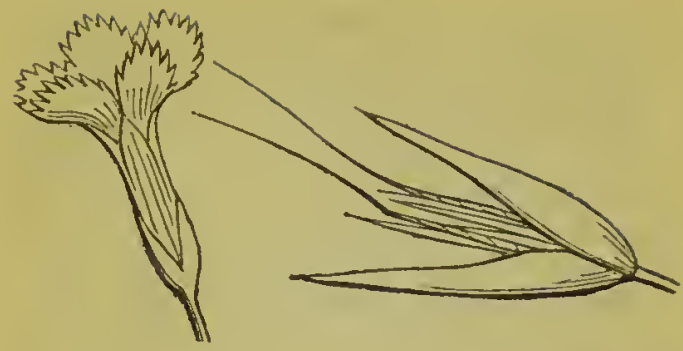

67

68

of Professor Martyn; this is remote from the flower, and can scarcely be distinguished clearly from a bractea.

The catkin (amentum), as in the hazel, $P l .43, b$, which consists of a conmon receptacle, of a cylindrical form, beset with numerous scales, each of which is accompanied by one or more stamens or pistils, so that the whole forms an aggregate flower.

The sheuth (spatha), a corering which bursts longitudinally, and is more or less remote from the flower; as in the arum, $\mathrm{Pl.} 27$. The husk (gluma), $f .68$, the popular calyx of grasses, and grass-like plants, of a chaffy texture; they are usually compressed, embracing each other at the base. The scaly sheath (perichotium), $f$. 69, investing the fertile flower, and consequently the base of the fruit stalk, in some mosses. The wrapper (volva), 


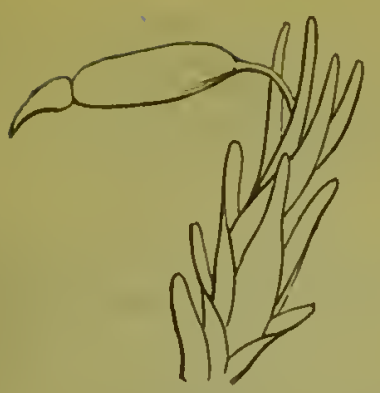

69

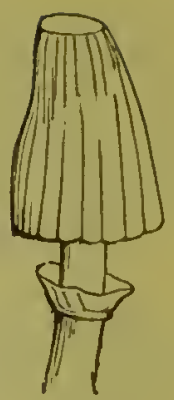

70

$f$. 70 , or corering of the fungus tribe; of a membranons texture, concealing their parts of fructificition, and, in due time, bursting all round, forming a ring upon the stalk.

\section{OF THE COROLLA.}

In examining the parts of flowers in general, we find, immedialely within the calyx, another whirl or rank of delicate, and often highly coloured leaves, and which are significantly called the flower, because of their gaudy colour and elegant expansion. This Botanists call the corolla; and it is either entire, or composed of separute parts; its divisions are called petals,

$$
\text { s } 2
$$


and consequently it is either monopetalous, thit is, one petaled, or polypetalous, that is, of niany petals. There is no such thing, however, as a corolla of one petal; as it is only apparently so by the union of the edges of the petals with each other.

$\Lambda$ petal is described as consisting of two

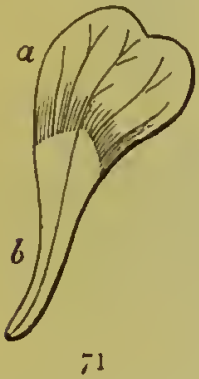
parts; namely, the lamina, $f$. $71, a$, or limb, and the unguis, $f .71, b$, or claw. The lutter is the narrow part at the base ; and is inserted into different members, or into different parts of members, as will be noticed hereafter.

When the petals are united below, and form what is called a tube, the orifice of which is the faux or throat, and the liubs are disposed in various forms and positions, they have received different significant titles, by which they are easily and briefly described.

If the limbs extend like rays from a centre, they are said to be rotate; if spread out like a platter, hypocratiform, $f$. 72 ; if like a funnel, infundibuliform, $f .73$; if like a bell, campanulate, $f .74$; and if like lips, labiate. When the divisions of a monopetalous corolla do not spread regularly round the centre, but take different directions upwurds and downwards, as in the order labiatx, the upper form what is called 


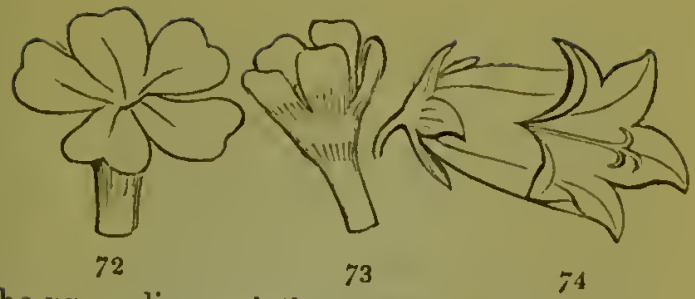

the upper lip, and the lower, the lower lip, or labellum. If the upper lip be arched, it is termed the galea, or helmet. When the two lips stand widely apart, the corolla is said to be ringent, $f .75$, or gaping; and if closely pressed together, as in frog's-month (Antirrhinum), it is said to be personate, $f .76$; because it has some resemblance to a face.

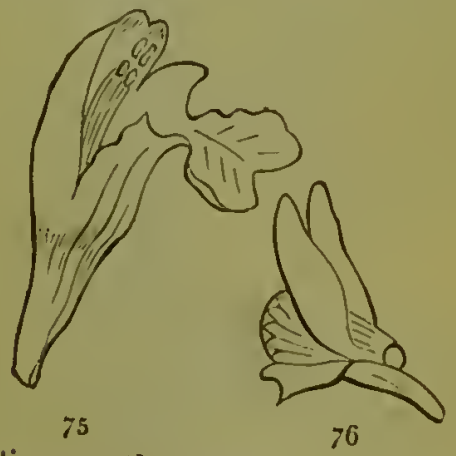

According as the petals of a polypetalons corolla are arranged the flowers have received 
different names from Botanists; hence we have rosaceous, liliaceous, caryphyllaceous, and cruciaceous flowers, so named, becanse of their similitude to a rose, a lily, a pink, or to the cross-formed flowers of the single garden stock. If the corolla be very irregular, with one petal very large, and standing orer the others like a hood or helmet, as is exemplified in the common monkshood (Aconitum), it is called cassideous. The corolla of the pea, because of its peculiar butterfly-shape, is called papilionaceous, $f .77$, and consists of five petals;

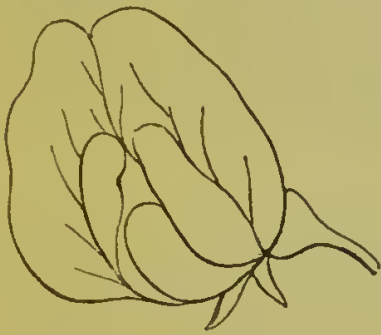

77 of which the upper one is called the vexillum, $f$. 78 , or standard; the two side ones are called ala, $f$. 79 , the wings; and the two lower ones being united by their lower margins, form the carina, f. 80 , or keel.

When the flower has no corolla, it is said to be apetalous; and when it is very small and forms part of a composite flower, it is termed a corollula; and whell, as it sometimes is, lengthened at the base into a hollow tube as in ol'chis and many other plants, this 
tube is called the spur, or in botanical language calcar.
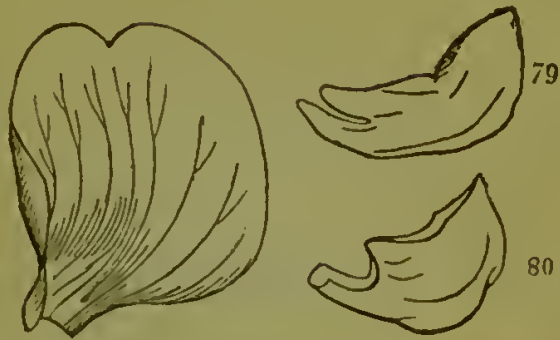

78

Those plants which present their flowers in umbels have corollas of very irregular form ; the exterior petals being much larger than the inner ones. Such are called irregular ; and all corollas are, in description, said to be regnlar or irregular, equal or unequal.

The petals are deciduons after flowering; some remain expanded only for a few hours; others are more permanent, continning in vigour for several days, opening in the diy, and closing again at night.

There are a few plants which are furnished with two or three whirls of petils, one within the other, in their natural state; of these the magnolia and nymphar are instances. These are very different from the double flowers of 
our gardens, which are inonstrous, not nornial productions.

Of the use of the corolla in the economy of the plant very little is known. It can hardly be regarded as a member for defence, seeing that in many cases, they depart from the only position in which they could serve either as a shade or as a shelter. But the corolla is certainly connected in some way or other with the grand purpose of the plint; namely, the production of seed; for as soon as that is accomplished, and not till then, the petals wither away.

This is a subject on which a little speculation may be allowed:- It is well known that many plants, and particularly exotics kept in glazed houses or frames, are barren, and never ripen seed, unless assisted by manual interposition; and the reason given for this is, because they are deprived of those currents of air, and visits of honey-seeking insects to which they would be exposed in the open air. Everyhody has heard of the caprification of figs, by means of an insect; and there is an equally well known fact in the business of gardening; namely, that the seeds of no particular species or variety of the genus brassica can be produced pure, if the flowers are expanded in the near neighbourhood of other flowering species of the same genus. This proves that the pollen or fecundifying dust of the anthers, is transmissible from 
flower to flower, and also that the dispersion of the pollen within the same flower requires some disturbing cause, either of wind or insects.

And how is the instrumentality of insecls to be secured, to effect this purpose of the plant? We answer, either by sight or scent. The honey secreted by flowers is attructive to the one sense, and the splendid colours of the corolla are equally so to the other. 'Thus, besides the embellishineut of the vegetable creation, so productive of delight to the senses of man, the fragrance and beauty of flowers may answer another purpose, no less necessary in the economy of the plant itself than the results are to those beings for whom they were created.

"The colours of the corolla arise from the deposition of refleclive atoms of matter in the cellulas of the perenchyma ; even white petals are so in consequence of the depnsit of a dull white substance, and not because of the absence of colouring." - Lind.

OF THE CORONA.

The corolla is often furnished with various appendiges, which, in the school of Linnieus, were considered as distinct inembers of the 
flower, and as they were supposed to be instrumental in the secretion of honey, they were called the nectarium. But by subsequent and more accurate investigation, this member was seen to occupy so many different situations, and in which the agency assigned to it could not be fulfilled, the title has been dropped; and distinct characters have been substituted, which are considered as more consistent with the inproved state of the science.

The place of the nectarium was either upon, or immediately within the petals of the corolla. Sometimes it was described as a nectariferous cavity or claw, at the inner base of the petal ; or as a circle or tuft of hairs in the throat of, or in the shape of a cup or long tube, within the corolla, so conspicuous in the narcissus, $f .81$. In this last state it is now

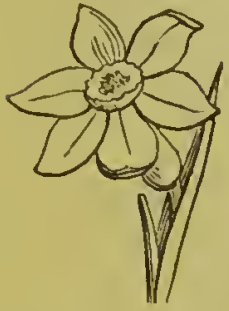

81 described as the corona. In some flowers, instead of being entire, like the edge of a cup, it is split into segments which stand erect above the limbs of the petals, as in Silene. In Stapelia it forms a thick fleshy mass corering the ovarium, and adhering to the stamens, in which state it takes the name of orbiculus; and this lias again certain nppendages which have also distinguishing epithets.

Some flowers are furnished with most benu- 
tiful coronas ; such are the parti-coloured rays which rise within the petals of the passion flower; or which cover the stamens of the iris; or the spurs which are elerated on stalks, us in aconitum; or as the nectariferous spurs attachcd to the petals of the larkspur (delphinium); or to the much more inflated one, called a slipper, belonging to the C'ypripedium, or ladies' slipper. Such indeed are the great variety of forms assumed by those members of the flower, and which are clearly neither petals nor sta. mens, that it is matter of difliculty witl many Botanists to describe them otherwise than by asserting that they are metamorphosed petals, or abortive stamens.

OF THE STAMENS.

The next rank of members within the corolla and its appendnges are the stanens. In number they vary from n single one

3 to a hundred or more; they are the consists of three parts-namely, the filument, $f .82 a . ;$ but which is not always present-the anther, $f .82 \mathrm{~b}$.; and the pollen therein contrined. The stamens are variously seated; sometimes on a body in the centre of the flower called a receptacle, to be des82 cribed hereafter; sometimes on the 
petals, or at least attuched to them for the greater part of the length of the filament; sometimes they are said to be seated on the inner surface of the calyx; and, in some plants, the anthers deprived of filaments are fixed to the pistillum. In most cases the stamens stand singly; but are sometimes united, either by a brotherhood of the filaments, or by a union of the anthers joined side to side round the style, in which case they are said to be syngenesious. The filaments are linear, or flattened like a leaf, and support one anther usually, but sometimes several. The anther consists of one or severil cells, generally bursting lengthwise to discharge the pollen. They ure of rarious forms and colours, though for the most part yellow. The pollen is a fine impalpable powder; but when viewed with a microscope the grains appear of very diflerent and curious forms. Some anthers have the power of discharging the pollen in clouds by a peculiar mechanism of the cells.

The stamens of some plints possess a very interesting kind of irritability. Those of the common berberry, when undisturbed, lie upon the petals; but if the inner side of the filament be touched near the base, by a straw or any slender body, the stamen immediately bends itself upward, till the anther touches the stigma, the female organ of the flower.

The number, and siturtion, and comparative 
length of the stamens, are particulars on which some of the rules of systematic Botany hare been, and still are founded; such as when the filanents are combined in one mass, this ussocintion is said to be a brotherhoorl, or an adelphia; hence we have monodelploous, diadelphous, triadelphous, and polydelphous associations; signifying that the brotherhoods are one, two, three, ni many fold. And there are also other general terms applied to the stamens, as whether they are exserted, that is, stinding out beyond the petals; or included, kept within, or shorter thin the corolla; if all bend to one side, they are sind to be declinate; if two out of four be shorter, they are didydamous; and if two out of six be longest, they ure tetradynamous.

The manner in which the an thers are attached to the filament is particularly marked by Botanists; when they are fixed by the base, they are said to be innate; when by the bach, they are adnate; when by a single point near the iniddle, they are said to be versatile; because they swing as if on a pivot; exemplified in all the grisses.

The bursting of the anther is called its dehiscence, and when this takes place, the female parts of the flower are usunlly ready for the reception of the pollen discharged from the anther. Without the influence of the pollen conresed to the enbryo seeds already lormed in 
the ovarium, they would be itbortive and useless.

This consumination is therefore the principal function of the stamens, and when that is completed they wither away.

OF THE DISI.

In Linnæan Botany, this term was used to identify that flat body on which the florets of composite flowers were fixed. In the modern schools of Botany, the term is used to denote it distinct member which is usually found between the base of the anthers and that of the pistillum. It appears in most cases as an entire or broken fleshy ring, sometimes adhering to the calyx, in which case it is said to be perigynous; or it is found surmounting the summit of the ovariun, in which case it is epigynous.

The disk is never a very conspicuous member of the flower; it is only detectable by the scrutinising Botanist, who is constantly using the glass and dissecting knife; and in drawing up descriptions, it is necessary to be particularly noticed. The use of it, as an organ of the inflorescence, has never yet been appreciated; for it is ruther regarded as a superfluous abortion, than the natural form of a necessary organ. 
There seems, however, to be no absolute necessity for arriving at such a conclusion, merely beciluse its use in the systent is unknown. Our knowledge of vegetable action is as yet by fur too limited, to enable us to say with certainty what is, or what is not, useful in the economy of the plant.

\section{OF: THE PISTILLUN.}

The pistillum is the columnar body, which occupies the centre of the flower. From its station and importance, it may be considered as the principal compound organ of the system. It is surrounded by the calyx and corolla; and as it is that memher whence the fruit and seeds are produced, it maly be properly; as it hitherto has been, called the female part of the flower.

The pistillum consists of three parts, numely, the ovarium, occupying the base; the style, and the stigma.

The ovarium, $f .83, a$, is a hollow case enclosing the embryo seeds, and often divided into two or more cells or cavities. It ultimately becomes the fruit; and consequently, whatever may be the structure of the ovarium, such nust necessarily be that of the fruit. It is sometimes sumk within the cillyx, whicl continues to be 


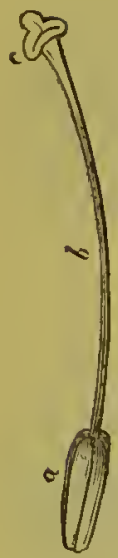

83

the outer integument of the fruit, as is instanced in the pomaceo, or common pear and apple. When so placed, it is said to be inferior. But when the ovarium becomes free from the embrace of the calyx, and swells entirely above the sepals, it is then said to be superior.

In many cases the ovarium sits closely upon the twig producing it ; in otliers it is seated on a long stalk, as in the passion flower: this stalk is called the thecaphore. The interior of the ovarium, as already observed, consists of one, or is variously divided into cavities or locuments. In eacli locument there is a member, either central, or proceeding from the partitions, angles, or walls of the ovarium, to which the seeds are attached by their umbilical cords called the placenta. The seeds, after fertilization, are increased in size, as well as their integuments; and the whole swelling together is cilled grossification. This enlargement of the ovarium ends in the full maturity of the seeds, and in the full maturity of the fruit, to be adverted to here. after.

The next part of the pistillum is the style, $f .83, b$, and which, when present, connects the orarium and stigma. When not present, the 
stigma is seated immedintely on the ovarium, as instanced in the poppy. It is usually taper, or thiliform, or thick, and sometimes angular; but rarely flat and coloured, as it appears in iris and in canna.

'The style is nsually smooth; but in some plants it is thickly beset with hairs. Sometimes these hairs stand in a whirl, or form a cup below the stigma. Many styles are not single, as they uppear to be, but composed of several united together; each belonging to a cell in the ovarium, and surmounted by a lobe of the stigma at top.

The stigma, $f .83, c$, is the uppermost part or summit of the pistillum, and is the only member of the whole plant that has no cuticle. It is, therefore, naked, but is alwa's very moist, or covered with soft down or papilla. 'This state of the stigma is a provision of nature, in order that the discharged pollen may the more certainly be caught and retained for the purpose of lecundifying the ovula. In shape the stigmi is either round with a notch on one sicle, or consists of several lobes, or of rays forming a verticellus as exemplified in gerunium.

Both style and stigma appearing in many different forms, leads careless observers to suppose that some of their appendages are stigmatic, which they really are not ; nothing is stigma but the secreting surface, before alluded to, for it is this secreting power which characterises 
the true stigma, whether it be moist, or papil. lose, or fungous.

The stigmata are distinct from surrounding bodies, and freely exposed to the contact of pollen, in the great majority of flowers; but in the curious ovder asclepiadacea, they are united with the anthers in a solid mass, of which the angles only that are in contuct with the cells of the anther are free and susceptible of fertilisation.-Lind.

Although there are no very risible tubes, leading from the stigma to the ovarium, to ficilitate the passage of the pollen to its destination; yet the central tissue of the style is of a very loose and porous texture, which seems to transmit the pollen, or its influence, as efficiently.

As the ovirium is a rery complicated organ, and particularly in some genera, Botanists have paid inuch attention to its rudimental, as well ns to its mature state; including all its translormations during its progress to perfect ripeness. Such inquiry, says Dr. Lindley, would, perhaps, be of less importance, if none but structure of a rery regular and uniform kind were to exist; but considering the numberless anomalies that the pistillum exhibits, it becomes at once one of the most difficult and most essential parts of a student's investigation.

$\mathrm{We}$ shall here deem it necessary to gire only the most common and simple forms, and distinguishing characters of the different kinds of 
seed-vessels; in order that the student may not be perplexed by a multitude of names and distinctions, which are fitter for those who have already made considerable progress in the study of the science.

And here we turn with pleasure to that smooth heaten path laid down for us by the immortil Linnæus, and whose system, although departed from by the inodern schools of Botany", their teachers still allow, is an excellent introduction to the more recondite sy'stem of Jussieu.

Agreeing in this opinion, we shall, therefore, in the first place, proceed to quote what Lin. naus wrote as to the titles of the different forms of seed-vessels.

Every different description of seed-vessels was comprehended under one or other of the following characters; namely, pomum, $f .84$, an apple, that is, a pulpy pericarp, or fruit without

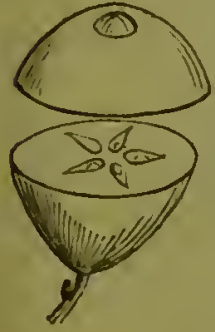

81

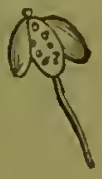
opening or valves, and generally enclosing a membranaceous cipsule, consisting of several cells : - example, the orchard apple. When this membranaceous seedressel is uncovered by pulp, it is called a capsula, sig8.5 nifying a little chest, 
and which, when ripe, opens spontaneously, either by valves or in sume other determinate manner. Sometines the capsula is without valves, as in the ash; many-valved, as in the woodsorrel (oxalis), or only one-valved, as in the primrose. A pod, $P l .42$, was called siliqua, which is a dry pericarp or two-valved fruit, with opposite seams to which the seeds are altached. A silicula, $f .85$, is also a pod, but short and roundish, or heart-shaped, as in

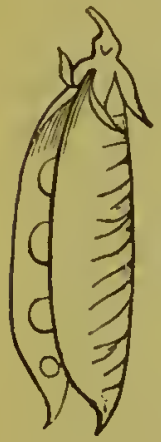

86 shepherd's purse (thlaspi). Legume, $f .86$, is also a pod, which, when ripe, is dry and long, having two valves and seams, to one of which the seeds are fixed, as in the common pea ; it is onecelled, and contains one or many seeds, is rough or smooth, fleshy or membranaceous. When the seed-vessel resembles a bag, it is called a folliculus. When it is a pulpy pericarp surrounding a stone or nut, as in the peach, it is called a drupe, f. 87 ; and when the pericurp is soft and pulpy, containing one or several seeds, but without valves or capsule, it is called bacca, $f .88$, or berry, of which the currant is an example. Another kind of seed-vessel is the cone borne on fir-trees, and this was by Linnæus designuted u strobile, $f .89$; and which is a 

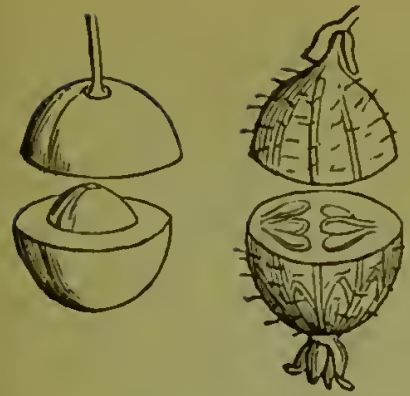

88

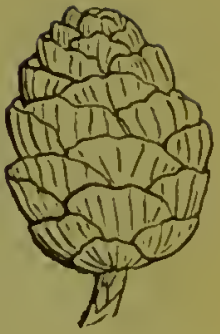

89

woody amentum, the separate carpills of which are covered with scales enclosing the seeds.

These terms are still useful in descriptive Botany, though several of then are no longer used. The particular description of the manner in which the leares of the plant are metamorphosed into seed-ressels is called carpology. When a single leaf is rolled together to form it seed-cell, it is called a carpellum; and when there are more pistils than one in a flower, they spring from a whirl of leares, and are carpella. This branch of botanical science belongs to what is called morphology, and will be noticed in the sequel. But it appears that this part of the plant has been more closely studied than any other part, by a great number of the first Botunists of the present time; and they seem to have vied with ench 
other who should fix the glossology of this organ and its parts. 'That terms as significant and comprehensive as possible should be chosen, there can be no doubt; but there is a difficulty in getting those of any one author universally adopted. Dr. Lindley has arranged fruits, or seed-vessels, in four classes, viz.,

1. Apocarpi, containing six divisions: Utriculus, one-celled ; Achenium, one-seeded ; Drupa, one-celled, one or-two-seeded: Folliculus, one-celled, many seeded; Legumen, a pod; Lomentum, a jointed pod.

2. AgGREGati, fruit aggregate : viz., Elaris, ovaries distinct; Syncarpium, ovaries cohering into a solid mass; Cynarrhodum, ovaries distinct, pericarpia hard.

3. Syncarpi, fruit compound: viz., Caryopsis, one-celled, one-seeded ; Regma, three or more celled; Carcerulus, many seeded, superior ; Samara, a key, two or more celled, superior; Pyxidium, one-celled, many seeded; Conceptaculum, two-celled, many seeded; Siliqua, one or two-celled; Silicula, one or two-celled, pod rounded; Ceratium, one-celled, many seeded; Capsula, one or many seeded; Amphisarca, many celled, many seeded, pericarpium fleshy; Tryma, by abortion, one-celled; Nuculanum, two or more seeded; Hesperidium, many celled, few seeded; Glans, onecelled, one or few seeded; Cypsilla, one- 
seeded, one-celled; Cremocarpum, two to five-celled, inferior; Deplotegia, one or many celled-difiers from the capsule only in being adherent to the calyx; Pomum, two or more celled; Pepo, one-celled, many seeded; Bacca, a berry, many celled, many seeded; Balausta, many celled.

4. AxтнослирI, collective firuits: viz., Diclesium, one-seeded, endehiscent; Sphalerocarpum, one-seeded, enclosed in a fleshy perianthium ; Syconus, it fleshy rachis, having the form of a hollow receptacle; Strobilus, a cone, the cupilla scale-like; Sorosis, a spike, converted into tleshy fruit by the cohesion of the ovaria with its envelopes, cx. mulberry.

These are the titles used in the language of Botany, for identifying the dillerent forms of seed-ressels and fruits, and the nse of which, either in conversation or in writings, very much abritges descriptions.

Botanists make it good distinction between fruits and seeds, by saying that whenever there are any remains of a style or stygma upon the production, it is, whatever may be its size, it fruit; and when no such mark is risible, it is a seed. 'Thus, the capsule of the poppy', the luscious and inviting forms of the peach, pear, and cherry, are fruits; while the largest nut is only a seed when stripped of its outer investments. The parts composing u fruit are thus 
denoininated: the outer skin is the epicarpium, the intermediate pulp is the sarcocarpium, and the shell of the stone which contains the ovula or kernel is the endocarpium.

As there are several parts of flowers which are either entirely wanting or undeveloped, so we often see fruits, which we call ripe and usefnl, imperfect in what we would say are the most essential parts of their organization. In flowers the calyx and corolla are united; or if a calyx be present, the corolla is absent: sometimes the anthers have no filaments, and sometimes the stigma has no style. So we fund in fruits kernels which have no endocarpium, and berries which have no seeds.

OF THE RECEPTACLE.

The receptacle, $f .90$, is the point of the peduncle, or branch,

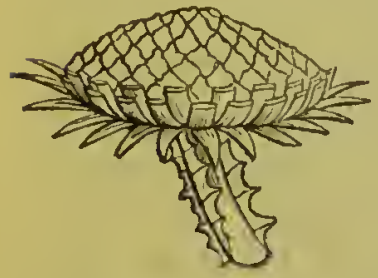

90 on which all the other parts of the fructification are seated. Sometimes it is entirely flat, or a little prominent in the middle, or dritwn out into a cone, either solid 
or hollow. In another remarkable case its conical form is reversed, and it becomes a deep and hollow cavity, having the flowers, either male or female, seated on its interior surface. 'This form occurs in the common fig, the receptacle becoming the pulpy eatable part of the fructification.

In many ordinary cases the calyx, corolla, stamens, corona, and disk, are all seated on the receptacle; and in describing uny of these members it is always noted whether or not they are seated on the receptacle; this circumstance often constituting a generic distinction.

\section{OF THE OVULUM.}

The production of the orula or seeds is the last and most important effort of a plant, whether that result happens in the course of one summer, as is the case with annuals; or in two summers, as occurs in biemninls; or in severul summers, as shown in perennials. In the lust case it is necessary to expluin that, though the flowers and fruit of both trees and shrubs are developed and matured in one summer, yet it is obvious that these are in a state of preparation for several years previous; some perfecting their flowers in two, others in three, 
and others again requiring a period of several years to advance a leaf-bud to that of a flowerbud.

In all cases, however, the production of ripe seed is the ultimate effort of a plant, or distinct. division of a perennial plant; and by which the kind is reproduced and perpetuated.

Those Botanists who have amused themselves by prying into the hidden processes of incipient vegetation, affirm that the ovulum is a sinall, semipellucid, pulpy body, borne by the placentu (a member in the centre, or attached to the sutores or walls of the ovarium) and gradually acquiring the perfect form of a seed.

'The internal structure of the ovulum is exceedingly difficult to determine, either in consequence of its minuteness or of the extreme delicacy of its parts. But it has been minutely examined; and the main object is, probably, to discover whether any, or what change takes place after impregnation; for assuredly, whatever envelopes, or purts, are visible in the mature seed, inust be present in its immature state. This notion is even sanctioned by $\mathbf{M}$. Mirbel, one of the most accurate of observers, when speaking of some reins or bundles of tubes, which though very visible in some plants, are invisible in others, although he deems their non-appearance as no prool of their absence. Were this belief more general among those who investigate and describe the immatur" 
parts of plants, there would be much less attributed to what are called spurions or accidental developments.

The results of these microscopic observations are, the discovery that the orulum is, at first, apparently lomogeneous, but us it advances in growtl it is gradually enclosed in two sacs or integnments, which are open only ut their apex, - where, in both these sacs, a pitsage exists, called the foramen. The central part is "Heshy, pointed inass, called the nuclens. The exterior sac is called the primine, the next within is called secondine, and within both these is the nucleus. Besides the two external integuments M. Mirbel has remarked the occusional presence of three others peculiar to the nucleus, which he calls the tercine, quartine, and quintine. The fluid matter contained within the nucleus is called the liquor amnios, and is supposed to be that which nourishes the embryo during its growtls.

This embryo, when ripe, is the rudiment of the future plant, and contains a basis, whence all the future members of the infant plant are developed. It is a regetable egg, which has certain characters belonging to itself: the base of a seed is always that point by which it is attuched to the placenta, and which is called the hilum: the opposite point to this may naturally be supposed the apex; but this is but seldom the case, as the true apex is sometimes 
very near the hilum, and, according to $\mathrm{Dr}$. Lindley, the place of the true apex is indicated by lines concentrated over it, - which lines are visible on the testa or outer covering of the seed. If such lines are undistingnishable, another indication of the apex resides in a little brown spot, which, when visible, is called the chalaza.

The integuments of a seed are the testa: the embryo occupies the centre, between which and the testa lies the albumen, a substance so called because it often resembles the white of an egg when boiled. The testa is of very various texture; it is horny or leathery, spongy or woody. The surface is smooth or rough, highly polished or beset with hairs.

The embryo occupies the centre of the seed, and, as before observed, is the rudiment of $a$ future plant : it is usually single, rarely double : and divided into three parts: namely, the radicle, cotyledons, and plumula. Some Botanists make a fourth division: namely, the cauliculus, or origin of the stem, occupying a line between the radicle and the plumula. If the seed of a dicotyledonous plant be placed in favourable circumstances, the following plienomena occur: the radicle descends and becomes a little root; the cauliculus rises upward, bearing the two cotyledons, which expand above the surface of the soil; and the plumula rising from between exhibits a slender stem and leares. 
This is the usual process of the germination of a dicotyledonous plant; but there are some exceptions to this law: first, in the cohesion of the cotyledons within the surface, instead of uufolding in the air; second, in an increase of their number; third, in their occasional absence; and fourthly, in their inequality. 'The cohesion of the cotyledons occurs in the horsecliesnut : an increase in their number (or perhaps it may be called a sub-division of the two) is seen in the genus pinus: their occasional absence occurs in the cuscuta: inequality of the cotyledons is rare, but is observable in the genus cycas.

Havivg thus far reviewed and briefly described the various tissues and nembers forming the organic structure of flowering plants, we come now to the consideration of certain phenomena and particulars of a more general character, exhibited by, or which allect every grade of the vegetable kindom.

OF THE RE-PRODUCTION OF PLANTS.

To "multiply and replenish the earth" was the high behest of the Almighty Anthor of nature to all his living creatures-vegetalles as well as animals. Nor were the latter gifted 
with higher powers to obey the mandate than were the former - the innumerable plants which clothed the face of the green earth, ind which sprung up after the work of the third day. Then it was that "the earth brought fortlı grass, and the herb yielding seed, and the fruit-tree yielding fruit, whose seed was in itself, each after his kind." All these new creations continued to yield their seed spontaneously to perpetuate the species, and to fulfil the first omnipotent command.

But though dissemination was the most effectual and most general way of distributing the primitive plants, yet, as there were many birds and beasts which subsisted entirely on seeds and fruits, it appeared necessary that plants should be endowed with other tendencies or powers to re-produce themselves independently of seed.

'I'o show the different processes by which plants re-produce themselves is the ohject of this section; and having already described how the ovulum or seed originates and becomes mature, we have here, in the first place, to state how seeds are dispersed and self-sown; and next, proceed to show how plants increase themselves otherwise than by seed.

When seeds are thoroughly ripe they, in most cases, drop. from the tree to the earth, and there remain to be covered with leares which soon fall after them. This is the only 
covering they are naturally destined to receive. Some seeds ure furnished with alce or wings, by which they are transportcd in the wind to considerable distances from the place where they grew. Others are furnished with a pappus, which, from its curious parasol appenclage, is exceedingly buoynt, and are by this wafted far away from the mother plant. Some seeds are beset with looked hair's, by which they cling to the fur of animals, and consequently are carried far and wide. Others again have long awns, the bise of which is spirally twisted, and which, relaxing in dry, and slurinking in wet weather, remores them, hy these alternate motions, to a distance from where they fall upon the ground.

In some instances seeds are scattered around by an elastic action of the valres of their capsules. Under the influence of a hot sun, the valres of some seed-ressels, and the scales of others, are suddenly separated with a snapping noise, discharging the seeds witl considerable force.

Sometimes birds are the agents appointed to disseminate plants to distant places. The mistletoe is trumsported by the mistle-thrush, which derour the berries; and cherry stones are planted by both rooks and jays. Aquatic plants ure removed from place to place by ducks and other water-fowl, they conveying the seeds not in, but upon their broad bills by accident. 
It is hardly worth alluding to the action of winds and running streams in the dispersion of seeds $_{3}$ as these are mere accidents, not the results of design.

Besides the reproduction of plants hy seeds, there are other means by which they are increased. Many of them, instead of seeds which may be buried in the ground, or kept in the granary for ages, produce living progeny even in the seed-ressel. This viviparous tendency is exhibited in the onion tribe (allium), as well as by several of the grasses. Even the common winter wheat, in wet seasons, too readily presents this premature germination amid the humid chaff of the ear. In this case we have living plants discharged from the parent instead of seeds; and other plants have not only the power of producing seed in their proper seedvessel, but also the power of forming and discharging buds from the axils of their peduncles, and their leaves, which have all the prerequisites of perfect seeds. These deciduous buds are curiously constituted, being of a character between a bulb and a seed; and from which as perfect plants are obtained as from either bulbs or seeds.

The complicated power of reproduction is exemplified in several species of the genus Lili$\mathrm{um}$, as the bulb-bearing, and tiger lilies for instance; which shows how carefully nature hits guarded these plants from extinction. 
Most other bulbous stemmed plunts are prorided with double powers of repraduction. They ripen seeds, and increase themselves by what are commonly culled off-sets. And it is remurkable, that as the one or other of these organs is increatsed, in like proportion is the other diminished. If many seeds be ripened, few or no oll-sets will be produced, and vice versí. And moreover, if the cultivator would rithel have a litrge increase of oft-sets than have both, he has only to leprive the plant of both its tlowers and leaves.

A great majority of herbaceous plants have similar powers of reproduction, for while perfecting seeds they are also extending themselves hy subdivisions at the root, and sone of them lave at triple inode of increasing themselves. For instance the strawberry; this fruitbeiring herb not only ripens seed, and cxtends the crown of its roots by lateral branches or divisions, but it also ejects from its crown another description of progeny, called muners, sent off in all directions; so that whit with the runners, and secondary runners produced from the first, a strawberry plant, if allowed, would quickly usurp the whole surfice of in border, or eren that of it whole gatrden to itself. berry plant; and inother useful ind well-knowculiniry vegetable may also be instanced ass pos:sessing a power of reproduction in it three-finli 
way, not much inferior to that of the strawberry. 'The potatoe bears its bunches of apples well filled with seed; it selds out numerous rumners under the surface, to each of which a tuber, greater or less in size, and studded all over with many germs, each of which in the following year forns, or may forn, independent plants; and to these tubers and seeds may be udded another set of tubers, occasionally produced on the principal stem in the axils of the leaves; and which last, though never used, are equally cipible of perpetuating the species as either the seeds or the underground tubers.

Almost all the perennial grasses increase themselves hoth by seeds and by divisions at the root, as well as by runners both above and beneath the surface of the ground, in which character they are called couchyrass, and are a great plague to the cultivator of arable land.

Other herbaceous plants inherit wonderful powers of reproduction; their underground stems are so thickly studded with vital germs or buds, that every the smallest portion of these stems will form new independent plants. These are denounced as weeds, and among others the dock, dandelion, and bindweed (convolvulus arvensis), are some of the worst.

Many trees and shrubs extend and multiply themselves by suckers as well as by seeds. The suckers are produced from roots which are beset with buds, like the stems and 
branches; and which buds are dereloped, rise through the surface, and become wavers round the parent stem. T'rees which produce no perfect seeds are most liable to produce numerous suckers:-instance the English elm, and several of the poplars.

These are the various ways in which the different descriptions of plants increase or extend their species; and from which it appears, that they are constituted very like aninals in respect of reproduction. Are birds oviparous? so are plants in the production of seeds. Are the beasts (mammalia) viviparous? so are plants in producing living progeny, from their seed-ressels, from their stems, and from their roots; and some of the most beautiful adaptations of nature, are exhibited in the arringement of surrounding circunstances, inposing, as it were, on the insentient plant the best menns by which the safety and welfare of their young may be acconiplished. A most impressive instance of sucl adaptation occurs in the habits of the mangrove (Rhizophora mangle), a tropical tree growing on the banks of large rivers, and on the sea coist, and even within the bounds of the ocean, as far as low-water mark. Their mode of rooting is peculiar; it consists, not like that of ordinary trees, of divisions of the stem helow the ground, but as it were of arches of roots above it, so that a more extended base is formed and a firmer hold es- 
tablished in the loose und swampy soil. From the summit of these bending roots the trunk of the mangrove springs, like a steeple from converging arches on which it is built.

Thus growing within the dry shore of the sea, or within the currents of mighty rivers, the final cause of the peculiar economy described in the germination of the seeds within the pericarp, and before the fruit has dropped from the parent bough, is evident ; for, were they to be shed as seeds usually are, they would fall into the water, and be carried far from any place that is fitted for their growth. But by the long rudicle first perforating the seed-vessel and descending into the mud, it actslike an anchor to the seedling when at last dropped from the tree. Thus forests of mangroves are formed of vist extent, unsafe to be trodden by huinan foot, but over which the savage natives pass, leaping or climbing from root to root for many miles, without once during to trust their weight upon the treacherous marshy ground. (Bur. Bot.) There are many shrubs, and a few of our forest trees, which extend themselves by accident, and which may be set down as another mode of reproduction. When a willow tree is blown down, and lies prostrate on moist ground, it immediately ejects fibrous roots into the soil; and from these new estahlished roots numerous young stems ascend and become trees. Other trees, as the spruce fir for instance, 
when its lower brunches are so extended us to lic on the ground, there take root, and thence send up new stems in every respect like the first.

It was, without doubt, from these accidental circumstances that cultivutors were at first taught the ant of manual propagation by layers and cuttings, so useful now in the business of the nurseryman. These manipulations, however, will be noticed in another section.

\section{OF VEGETABLF LITE.}

This is a most abstruse subject; it has puzzled many a philosophic mind; hardly two of the wisest enquirers are agreed in their opinions concerning vegetable life. One philosopher has snid, "life is the tolality of the functions which resist death;" another thinks that "life is a collection of phenomena that occur during a limited period in organized structures;" one lays down what he considers as an aphorisn, that "life is the active state of the animal [and vegetable] structure;" another, still nore laconic, avers that "life is inherent activity."

The above we gise as a kind of preface to the introduction of another and more comprehensive definition lately published, namely, that 
"life is that energy, or attribute, of organized structures which renders them capable of receiving and of obeying the impulse of stimuli. It is real, or it is potential: real, if the susceptibilities are in operation, as in the case of an animal in motion, or of a plant protruding its buds or blossoms; potentinl, if the susceptibilities are dormant, as in the case of an egg not hatched, or of a seed not sown; or as in the case of the hybernation, whether of plants or animals. Life originates in precedent life, and terminates in subsequent death, which is an extinction of all vital functions, and of all possibility of vital functions. Taking this definition with its illustration as our text, we pro. ceed to remark that life, in the exhibition of its phenomena, always presupposes the existence of certain peculiar conditions, previous, or concomitent, or consequent, without which it never has been known to manifest itself, and of which the most essential are the following,parentage, organization, aliment, aeration, temperature, death.'"-(Keith's Bot. Lex., p. 224.)

This definition we think is as complete as any other ever given of the phenomena of regetable life, there being only one idea which to us appears obscure, namely that the potential susceptibility can possibly be dormant; for surely it is not so, either in the egg not hatched, or the seed not sown; for both these bodies retain their susceptibilities, though from the 
absence of stimuli they are dormint. The allusion to the hybermation of animals is good, but we have doubts whether it be strictly applicable to plants.

If we study regetation with a view to discorer what regetable life really is, we can only mark its effects: that which is small becomes auplified; that which is closed becomes unfolded; and that which at one time is invisible is soon afterwards exposed to riew. We see the shoots lengthened, the leaves dereloped, and the flowers expinded; and whether these rise from a seed, or from a previously existing plint, for, from one or other, all accretion must proceed, there is no such thing as the brginning of life in a plant. 'The seed, or hulb, or tuber, or root, or branch, whence it sprung, gave it at once both ritulity and lorm.

We may also inark the circumstances under which such phenomena take place: we shall find that the temperature of the air must be above thirty-two degrees of Fahrenheit's thermometer; that the plant enjoys full air and light; and that a due degree of moisture is in the earth, in which the seed is sown or plant placed.

We may ulso notice which parts of the plant are undergoing transformation. We see both its height and diametric butk gradually increasing; we see its additional number of leares, and Howers, and fruit; and we know for a certainty 
thit all this is a consequence of, and is brought about by the life.

But if, for further satisfaction, we have it wish to know what is going on in the interior of the tree, as well as that which is so visible without, we shall certainly find that the whole frame and bulk of the tree remains exactly as it did twelve months before. Of this there is no increase or diminution whatever, if it be a young dicotyledonous tree. And it will be found that all the new additions of the present year, mentioned above, have been added to the exterior of the last year's frame. This fact, although already stated in a former page, is repeated to show the inquirer that the life has only "a local habitation", in the system, and that it is not resident, or at least not active, in every member of the plant.

The only proof we can possibly have of the seat, or the existence of regetable life, is in its progressive action. And als it is a well authenticated fact, that neither the alburnum nor liber are ever increased or diminished after they are once imposed, the life must desert them and reside elsewhere.

Where then is its resting place during winter, or in those seasons when it or its susceptibilities are said to be dormant? We must not jump) at an answer to this question; we must bring practical facts to bear upon it, and deduce our convictions accordingly. 
In the operation of grafting we can easily unite "s scion witl a stock. 'Tlue latter has u system of roots; its head is cut off, and replaced by the scion from another tree. $\Lambda$ union very soon takes place, not by any inosculation of the fibrous tissues of the two alburnums, or by those of the two barks, but by in umalgumation of a certuin viscous matter, which is always present between the alburnum and bark of the scion and stock, und which appenrs to act like a mutual cement to form the union.

l'ropagating certain kinds of plants by cuttings is a common practice. $A$ part of a young shoot is selected to be rooted, because it is found that the more active the life is in any part, that part is the most suitable for making cuttiugs. Watcling the process of their taking root when put in the gronnd, we observe that the rooting takes place in two ways. Sometimes root fibres are put forth at once, und invariably from the space between the alburnum and the inner bark; showing that neither the alburnum nor bark inherit uny vital power to eject nutritive organs. At other times the cutting, instead of fibres, presents il callosity, issuing out from between the bark and alburnum, and after a period of a week or two, often longer, also issue rootlets, which descend
into tlie ground.

Now, as neither bark nor wood are ever altered in their form after the summer growth is 
over, and as these members are incapable of showing any signs of possessing vitility so as to enlarge or extend their first forms, we must conclude that they are, is already said, deserted by the life as soon as they cease to grow.

So, in the case of layers, it is always the custom to twist or muke some incision in the part laid in the soil, to facilitate their rooting; and, on examining the rooting part, it is seen that all the new fibres proceed from between the wood and bark, and this, together with what has been observed of cutting, shows decidedly that the lile resides between the bark and alburntum in winter; and in this rery space all the accretion of new wood and liber during the next summer is deposited.

In this way we can trace the life to its principal station, both in winter and summer. But other queries remain to be put, namely, -Is the life a thing which can be seen or felt? Is there no membrane or otlier body, whence the fibres spoken of proceed? No dilatation of either the alburnum or liber into the space between them?

To the first question we answer, No; the life is not a sulstantial member of a plant; it is only an "attribute" of certain parts of a regetable hody, which is capable of "obeying the impulse of stimuli," namely, heat, air, light and humidity united in due degrees.

To the second and third questions the reply 
is - No membrane is apparent, nor is there any visible dilatation of eitler the alburnum or liber. The only thing risible is a thin layer of viscous matter, which serves to unite the bark with the wood.

But thin and almost imperceptible though it be, this viscid layer is certuinly the seat of the life during winter; and it is that which is swelled and fully formed into both wood and bark, in the course of the following suinmer.

We have stated that heat, air, light and water, are the stimulants of vegetation; but heat, air, and light have no stimnlating effect, either individually or collectively, unless inoisture be also present; this may be proved by sowing seed in a pan of dry sand. Heat and moisture cannot stimulate unless assisted by air: this is evident from the sound state of seeds which are deeply buried in the earth. Seed or plants may he excited into action by air and moisture; but if light be witlheld, they will neither acquire colour, flavour, nor substantiality.

It is the effects of those four elements which collectively operate on the vital principle of plants, and induce development of their expansible meinbranes by excitement, perhaps, of tlie fermentive qualities of the juices.

We have said that the life in a tree is only local; this requires explanation. Why, when we look at a fine healthy tree, should we suppose that it is not allogether a living individual 
being? Can it be possible that one portion of such a stately object should be alive and another portion dead? Yes, quite possible; and if the tree be very old, quite and obviously true also. But let us consider a tree which is young and vigorous-say an oak of twenty year's growth; surely, this must be all alive throughout. We answer, No, it is not; and the explanation follows:-In whatever portion or member of a tree the actual life resides, that member is increasing, or may be increased in volume; but all members that are not increasing, and cannot possibly be increased in hulk, are virtually dead; and though not actually decayed, they are verging to decay. All the previously deposed liyers of wood and bark, up to the present year, are in the latter predicament; active life lus left them, so that all future growth is over.

But though this be fact, yet it must be admitted that botl the wood and bark of a healthy tree continue to partake of the infuence of life long after their first formation. The timber of a young tree just felled is very different from that which has long been converted to use, certainly ; because the one is full of aqueous sap, and the other is sapless; and therefore, there is an appearance of fresliness and life in the one which is not in the other.

That this inust be the case is evident from the consideration, that the organs containing the actual life clothe the whole exterior surface 
of the tree; and, as the annual expansion of these orguns are the principal, if not the sole cruse of the ascent of the sap, as long as there is any connexion between the actire members on the exterior and the organization within, so long will the latter show signs of freshness and life, ulthough the actual life has long deserted them. The most recently imposed layers of both bark and alburnum are intimately connected with the living principle, and are chiefly employed in the conduction of sap; and it is obvious that, as long as any portion of the axis of timber is einployed as conduits for the sap, it may be said to be a live inember of the systein; but when the central layers of wood and outermost liyjers of bark cease to be so einployed, they are merely excrementitious, and soon fall to decily.

\section{OF TII: SAP.}

The sap is the juice found in plants: Botanists describe two kinds or conditions of it, namely, simple and elaborated. The simple
sap is that which is first taken into the system
by the roots, and before it hen by the roots, and before it has become assinilated with the essential juices. Elaborited sap is that which las passed through the organic 
upparatus, and becoine fully impregnated with the essential qualities of the system: hence, it is called the purfect sap.

'This knowledge of it is obtained by experiment; for as there are several kinds of trees whose juices are capable of being manufactured into sugar, and diflerent descriptions of low wine; if, in withdrawing the sap by plugging, the orifice be made too low on the trunk, the quility is inferior: but the higher the outlet is made, the richer the flowing liquid is found.

The sip ascends from the roots to the topmost parts, and gives rigidity to the shoots and leares, which they have not if in want of it. Much has been said and written to explain the phenomena of the sap, to common understandings a very simple allair. But simple as it appears to be, all the powers of nature hare been assembled, and their various forces united, to account for this simple process. We know that there are many natural sj phons of rascular or fibrous matter; such as it piece of porous cane, a strip of sponge, or a piece of list. All these readily absorb and convey water to any moderate height: and if these lifeless bodies act as conductors to such a fluid, surely the cellulur, rascular, and fibrous tissues of the vegetable fabric, energetic with life, must also do the same with redoubled activity und eflect. If, by the force of the life, vacuums are formed in the higher parts of the system, and ut the 
sane tine the spongiola of the roots are absorbing the moisture of the earth; gravitation is a ready agent to cause the ascent of any lower fluid to a ligher vacuum. Heat and moisture are usually combined at the surfuce of the eurth; and so much so, that a notuble vapour is constintly arising therefrom : and as the spongiolar are pervious to both heat and water, why should the erect tubes, and ressels of vegetable stems be not ready conduits to the received fluids?

'The sup, in its morements througli the system of the plant, is said to be freed from its aqueous portion through the transpiring anency of the leaves, the residue being the elaborated portion, destined for the solidification of the nobler or inore permaneist parts of the structure.

Sip extracted from plants by uny chemical or ofluer mechanical neans, or as it issues spontaneously from them, is found of very diflerent qualities, both us to consistence and essential properties. Resins, gums, oils, doc. ure common; and the materia medica is beholden to the juices of plants for many drugs, both sanutive und poisonous. Those different qualities are compounded by the vital chemistry of the plant, bectuse vegetable food in general is all very uuch the same.

Although the course of the sap is usually from the roots to the extremities of the 
branches, it is also transfusible in all directions; and always tends towards any outlet, whether to supply expanding shoots and foliage, or to escape at a wound. During winter it is coagulated by the cold, and nearly stagnant; but becomes liquified on the return of spring, and flows copiously from wounds. It becomes exhausted by the growth, as well as by: the heat of summer, and then scarcely flows from wounds. In autumn its motion becounes languid, and at last is again nearly arrested by the increasing cold.

The greater number of vegetable physiologists attribute to the sap the property of being "organizable," that is, its tendency to form itself into the organic fabric of the plant: but this being an invisible process, it is entirely. hidden from practical observation, and therefore cannot be practically explained.

When sap flows from wounds it assumes different appearances. In pruning it follows the knife like pure water; in some of the stonefruit trees it oozes out in the state of gum ; and among the cone-bearing tribes it comes out in drops of pure resin. From accidental bruises or wind-shakes, discharges of like qualities continue to pour out, for uonths and even for years together. The elm tree is very subject to be damaged by the flow of sap from wounds formed by the bases of rotten branches. 'This discliarge is unlike any of the above-mentioned: 
it is neither gum, resin, or pure water; but a thick turbid lintter, and which contains u con. siderable portion of sugar, as flies, wasps, and even bees appear fond of it in the summer and autumnal months.

Many methods of extracting the juices of trees for economical uses might be quoted: as the birch wine of the Scotch Ilighlands; the inaple sugar of North America; the gains fron Arabia; the asafotida of Persia (which however is the juice of an lierb); the croutchouc. und numerous other gums from India, are all obtuined by tapping, or making other incisions in the bark.

These various products show the wonderful powers with which the vegetable apparitus is endowed. Plants of very diflerent kinds, and though grown on the very same description of snil, produce very diflerent and opposite qualities in their membranaceous structure. It therefore appears, that the essential qualities are not conpounded by the selecting or attric. tive energies of the roots, but by the elaborating powers of the cellular and vilscular structure, under the united influences of lieat, air, and light. For it is well known that in all cises where there is not a sufficiency of air and light, the vegetable products, whitever they may be, are colourless and insipicl.

This circunstance shows that, although the quantity of nutritive matter may be absorbed by 
the roots, its qualities are matured by the influences of various fluids imbibed from the air.

That the juices of trees become concreted, or concentrated, in the first formed layers of both the wood and the bark, is very evident from the greater hardness, compactness, and ponderosity of the heart-wood, and which is easily proved by the process of maceration in a proper menstruum. By this means, colour, virtues, and the pulpy and cellular constitnents of the hardest woods are completely banished, learing only the fibrous skeleton to indicate the original form. This art of extracting colour is well known to the manufacturers of ornamental articles of household furniture, who, by the use of mordicants, can easily give variety to the graining of their polished goods.

In treating of the sap of trees it should not be forgotten to mention one circumstance relative to its spring morement, which is unknown, or, if known, is incomprehensible to many observers. The root is the grand inlet of the sap; and it is natural to suppose that its spring movement would commence at that source of supply; but the contrary is the case. The sap is first liquified, and in motion at the topmost branches of the tree, and long before any motion at all is perceivable at the botton of the trunk. And indeed when duly considered it cannot be otherwise. 'T'he whole superior parts of the system may easily be con- 
ceived to be replete with sap, congulated there by the cold of winter; every ressel and intercellular passige is clogged up, und therefore the fluds in the roots caunot ascend. But soon as the increasing warmth of spring liquifies the sap) ubove, and the bursting buds begin to crave supplies, a movement in the proximate vessels begins, and a flow is generated downuards, until the whole, that in the roots ulso, is in full
flow.

But it may be said, as this is an invisible process, how is the true movement known? We answer, by a very common and well known practice of the woodman, called bark-peeling. This business is performed in the spring of the year, and is commenced as soun as the bark parts easily from the wood. But it often happens that the top is partly clothed in green before the bark at the bottom of the trunk will run; and neither felling nor peeling can be performed till the butt can be stripped, because that is the most valuable portion.

This fact of the motion of the sap beginning at the top of the tree, is an unanswerable argument against those who believe that the whole body of silp in the liead sinks down into the roots in winter. For if this were really the case, the flow of sap would commence at the root, and not at the top.

This autumnal descent of the sap into the roots is somewhil akin to the "circulation of 
the sap," maintained as a fact by fo many phylologists, both ancient and modern. Soon is the circulation of the blood in animals was discovered, the circulation of the sap in vegetables was supposed to be carried on by a similar law. But as no circulating apparatus could be observed in the interior of plants, the notion was soon abandoned, though there are still a few modern philosophers who strive hurd to bolster up the old doctrine, but without success. They yield the idea of a regular circulation; but they cling to the supposition that there is a regular descent of the sap as well as a constant ascent. It must be admitted that there are a few prac. tical facts which support, if not the circulation, at least the probability of a descent of this fluid. These facts are, that if a rariegated jasmine be budded upon a common green one, the suckers which afterwards rise from the root of the latter will be variegated also; a result which could not happen unless some connexion existed between the variegated graft and the green root. The same circumstance sometimes occur's among the cultivated tribe of hollies.

But if it be allowed that there is a diffision of the sap in all directions; and if we admit the general opinion that the variegation of foliage is only a disease, we may easily conceive that a cisual intermixture of the sap would be sufficient to convey the disease to the suckers. For thongh the sap be in itself incapable of 
generating organs in the vegetuble system, it inay reasonably be deemed capable of transmitting colour.

\section{OF THE ACCLIMATATION OF PLANTS.}

Exotic plants, natives of the tropics or the warm parts of the temperate zones, are naturally impatient of cold, and particularly of frost ; but as we wisl to enrich our collections by the introduction of every ornamental plant that will live in our northern climate, we endearour to inure the tender beauties of the south by degrees to withstand the cold of our long winter nights, which management is called acclimatation.

'The first steps are, exposing them as early in the spring, and as late in the autumn, as may be done witl perfect safety; or covering them when necessary in winter, and decreasing the covering year after year, until they gain sufficient hardihood to bear all the rigours of our winter. These precautions are always taken in proving whether valuable plants be constitutionally hardy enougl to bear a greater. degree of cold than they were exposed to in their native habitation; for it is a doubtful matter whether a change of place will so affect a plant as to render its sap and membranes 
less susceptible of injury from cold merely by gradually exposing it to greater degrees of it. It is true that many plants formerly kept in the greenhouse and even in the stove are now planted in the open air. For instance, the Aucuba was treated as a hot-house plant in 1790 , bnt is now one of our hardiest evergreens; and, no doubt, was equally hardy from the first day of its introduction into Europe. For, on the other hand, we have several exotics which have been in our gardens for neurly two centuries, and are still as tender as they were at first: the potatoe and scarlet-runnerbean are examples.

We may however observe, that inuring a plant to a cold open situation renders it less liable to be hurt by frost than if it had a warmer sheltered place. Plants, even exotics, standing in a northern aspect are always hardier than those exposed to the sonth. But this is not altogether because the plant becomes more hardy, but because having received less excitement from the sun, it is in a better condition to bear a severe trial. It seems, therefore, that, in the practice of acclimatising plants, placing them in at north aspect during summer is better than placing them, as is usual, in a south exposure in the first year of triall. A north aspect induces a more moderate, or what may be called a more stunted habit; and, consequently the growth, whatever it may be, is 
of a firmer and more robust texture than if it had been cherished under wirmer skies.

The eflects of frost too, are locally more or less severe. It always fitls with more severity on the plants in the warm sheltered valley, than on those on the bleak hill. Not only because the latter are more hardy, but because they are assiled by frost of less intensity than that which attacks the luxuriant inuates of the humid valley.

All plants are more or less seasonal: that is, they grow in one season and rest in nnother; not, however, accorling to the calendar, but to their constitutional habits. Between the tropics the warmest season is that in which the native plants take their rest; the herbaceous sorts retire within the surface of the parched earth, and sulely repose in the centre of their bulbs, or tubers, or seeds; the shrubs and trees ripen and shed their seeds; all vegetation is in a state ol linguor, until the monsoon, or ruiny season sets in. In those torrid climes there ire a few exceptions to this rule: their indigenous palns seem to be ener-growing plants; as it is observable of them and other congenerous genera, that they are ever progressing in erolving their fronds, and yielding their fruit.

In the temperate latitudes the sensons of summer and winter are more distinctly marked, not ouly by the change of temperature, but by 
the appearance and habits of plants. The hatter are for the most part all alive in the one season and dormant in the other. And yet in our collections we have many plants which do not obey the impalse of summer, nor the repressions of winter. On the contrary, they are summer sleeping plants; retiring, like their tropical congeners, under ground, until the antumnal rains awake thein again to life. These are cliefly bulbs and tubers; and which, resting in summer, are prepared for expansion during winter and the following spring.

With respect to the seasonal habits of plants, and which differ so much from each other under the same atmospheric influences, no good reason can be assigned; and yet, we are fully persuaded that none of these obscure circumstances are exhibited in their erolutions, but are somehow or other necessary to their wellbeing and reproduction.

It is well known that flowers of rery attenuated structure are liable to injury, and even destruction from bright sunshine, even more, perhaps, than from keen frost. Some flowers expand only in the twilight, or during night, or early in the morning. 'The erening primrose (Eonothera), the great-flowering cereus, and the convolvulus major, are instances of these peculiarities. And in thus obeying a law of nature, we must conclude that this regetable instinct is a preservative phenomenon. Mlany 
of our choicest fruit trees present their flowers early in the season; and probubly becuuse a moderate temperature is most suitable for their perfect development.

OF THE COLOUR OY PLANTS.

To nccount for the various colours of the different members of plants has very much engaged the attention of natural philosophers. It is found that the membranes of plants are invuriubly colourless, and thut it is the qualities of their juices which acquire colour, from the action of the rays of light from the sun. This contitined coloured juice is called the chromule; and if this be small in quantity, the
leaves are pale, or if absent in patches, they are
variegated. varieguted.

There is a double series of the colours of flowers, and which are said to be oxidated and de-oxidated: the first is yellow, which passes into red and white, but never into blue; the second blue, which passes into red and white, but never into yellow. It is this law of the transmutation of colours of flowers which in. duced M. De Cundolle to declare, that we should never have a blue dahlia. In the process, says the snme authority, of oxidution, 
we have yellow-green, yellow, orange-yellow, orange, orangc-led, red. And in the process of de-oxidation, we have green-blue, blue, violet-blue, violet, violet-red, and red. All these, and other modifications of the chromule, occasioned by the degree of its oxidation, are the cause of the great diversity of colour in the diflerent members of plants.

The colours of flowers are subject to changes, and sometimes so suddenly as to show three diflerent tints in the course of one day; the Hibiscus mutabilis is an instance. The natural colours may be changed by the qualities of certaiu soils or manures laid to their roots; and is an art particularly studied by florists. Indeed to the highly manured composts used for bed and stage flowers, and to their being cultivated in snch close order, are to be attributed the vast variety of colours exhibited in the beds of ranunculus, tulips, \&c.

The varying tints of the foliage, from light to tark green, and to yellow, brown, and red, in the autumn, is remarkuble, and owing, it is supposed, to a change in the composition of their primary principles, accompanied with loss of water. 
OF THE DISFASES AYD FIXAL DECAY OH PLANTS.

$V$ Vegetables of every description are liable to disease, to wounds, and eventually death itself. Some diseanes is the canker, which destroys the hark and deranges the organization of the shoots, is usually attributed to the imbibition of noxious fluids by the roots in unsuitable soils. The oxides of metals, such as iron, so frequent in soine sorts of clay, are known to be exceedingly deleterious to many sorts of plants. But the inost common diseases of herbs, shrubs, and trees, nre cuused by parasitic fungi or insects. The parasites are inildew, rust, and numerous other fungi, lichens, and mosses. They ure ulso preyed on by a numerous host of insects, which destroy leaves, flowers, and linuit; blighting the hopes of the husbindman, and blasting the fairest prospect of the garlener. Nor are bolanical collections free from the annoyunce of some of the smallest, though nost pernicious of the insect tribes.

Plants are also subject to the inclemencies of the weather; the sun scorches, and the frosts lacerate; droughts wither, and imnooderate rain
sacllells.

The existence of plints includes very different portions of time. Some spring up and die in at 
few weeks or months: others survive for nearly two years, and many exist for centuries. The first are herbaceous annuals; the second are biennials; and the last are perennials.

There seems, however, to be no limit to the life of any perennial plant, did not other causes assist in their destruction. Natural decay begins at the centre of the trunk; and the defect extends year after year towards the circumference, and at a quicker rate than new layers of wood and bark are deposited on the outside, where the vitality is still in action. At last the massive trunk is reduced to a mere shell; and then the ruthless storm assails the hollow tree and lays it prostrate. All the aged trees which we see and read of, are hollow ; and those which hare been shreded as pollards, remain longer entire, because they have no lofty branches which the wind has power to disrupt and tear off.

But there is another description of plants, which may be described. They are those which although ranked among perennials, and continuing to grow for many yeurs, have only a li. mited period of existence; and, unlike other plants, do not increase themselves by any other mode than by seed. In fact they are individuals in the strictest sense of the term. They hare no suckers, no buds, no branches; but consist of a stem and fronds only, and a central or terminal fructification; which when developed, 
and the seeds are ripened, the roots, stem, and fronds, together with the fructifying members, die. This character of regetables is exemplified in few instances; we see divisions of plants, as the house leek (sempervivium), Anerican aloe (agave), and several others (which are not annuals) perish as soon as their fructing is complete: the maturation of seed being the final effort of the plant, or of one of its divisions. We say of one of its divisions; because compound plants, consist of several parts or branches; these are all consecutively approaching to the flowering state. The first or strongest flowers and dies; followed by the second and third in order; while a succession of young buds or branches are produced from the collet or crown of the root. But this compound structure is very different from the structure of those which we call individual plants, such as the talipot palin (corypha umbraculifera), which flowers but once. This has no progeny except seeds; but these are produced in such great quantity, that, at the death of the lofty parent, thousands of seminal progeny strew the ground far around the spot where the parent grew.

This is an admirable provision of nature, which gives to a plant but one way of reproducing itself, and that way so wonderfully prolific. Those plants which are constantly increasing theniselves by off-sets and runners, or by 
branches leaning upon the ground, are seldom burdened with seed; hut in the case of the palm alluded to, which has neither suckers nor other division, from which art or accident can rear another, it produces at once seed enough to establish an extensive forest of seedlings around. It is reported of this palm, that the scent of its numerons flowers is so orerpowering, that the Cingalese inhabitants, living near the talipot palms, cut them down before flowering to prevent the annoyance of their rank aroma.

A BIBEF HISTORY OF THE SCIENCE OF BO'TANY.

The preceding sections comprise the more prominent parts of phytological knowledge, which have been collected by the experience, and recorded by the assiduous care of former Botanists. And on taking a retrospective glance over those early times, when the science had as yet no place in the schools, it is interesting to see from what small beginnings the love, and study, and classification of plants, first took their rise.

'The first writer of note who treated of vegetation, of the origin and propagation of plants, 
of their anatomy and structure, and of regetable life was Theophristus the I,esbian, who was the disciple of $\Lambda$ ristotle, and flonrished in the third century before the Christian era. He describes only about five hundred plants; these he has arranged by a method which, howerer unsystematical, was well suited to the then state of knowledge. He distributes regetables into seven primary divisions, which are charncterised by their place of growth; their size, as trees or shrubs ; their use, as potherbs and escuent grain, and their lactescence. This was the short and rery imperfect alrungeunent of Theophrastus, who however is called the father of Botany.

The next botanical writer of repute was the indefatigable Dioscorides, a Grecian by birth, but under the Roman empire. He inade a catalogue of all the plants known in Greece, and the adjacent countries; together with their known virtnes and economical uses. Although Dinscorides lired four hundred years after the time at which Theophrastus wrote, it is remarkuble that he has not added more than about oue hundred plants to the former list. Dioscorides arranged his six hundred plants into four classes, namely, alimentary, aromatic, medicinal, and vimous.

This methol of clissification could not be useful, because the characters were not impressed on their exterior, neither does every 
part of a plant contain the same qualities; those of the root being often rery different from the qualities of the leares, and these not being objects of sight would prevent the identifi. cation of the species.

Nearly cotemporary with Dioscorides flourished the still well known authors Antonius Musa, Cato, Varro, Virgil, and Columella. The two last eminent us agricultural writers; and whose works even on such subjecls are still valuable.

Pliny the elder in his natural history, transcribes the lists of plants of both Theophrastus and Dioscorides, together with the names of several new plants which his industry had enabled him to glean from those who were probably not authors. His arrangement is the most ancient one of trees, slurubs, and herbs; and although no botanist, is notwithstanding a useful writer. His catalogue of plants contaius above a thousand names; being double the number of those described by Theophrastus.

Galen, so celebrated in medicine, with several other minor writers on the medical virtues of plants, comes next on the stage of botanical history. Galen's plants are more interesting to the student of pharmacy than to the Botanist; and indeed from the time of Pliny, the knowledge, the very limited knowledge of the ancients on this science seemed to lave declined, rather than adranced. Systematic botany is 
rational principles had not yet occurred to any one; and all that was done in those barbarous times were only a few translations; and though the names of De Dondis, Bosco, and Cresentius, figure as botanical writers in the fourteen th and fifteenth centuries, they made butlittle progress in the science. They wrote of plants indeed, but without method, and withont knowledige. All was one great chaos; and that man would have undertaken an Herculean task who would have tried to put such materials into order.

In the beginning of the sixteenth century, the Botany of the ancients was restored by some excellent translations, enriched by the commen. turies of Fuchsius, Rnellius, Gesner, and Matthiolus. Soon after followed Hieronymus Bock, better known by the name of Trigus, the first of the moderns who attempted a methodical distribution of regetables. In his history of plants, published in 1532, he divides the eight hundred species there described in to three classes only, "founded on the qualities of vegetables, their habits, figure, and size." At this period Lonicer, Dodonaus, L'Obel, Clussius, Brunsfelsius, Monardus, and some others were botanical writers; hut their distinctions were not superior to those of Tragus. And were it not that their names are handed down to their posterity, by the plants named in honour of them by succeeding Botanists, their memory would have at this time been quite forgotten. 
Botany was in this unsettled and unsystema. tic state, when Conrad Gesner suggested the first idea of a systematic arrangement of plants. He was a Swiss by birth, and his mind partook of the varied and lofty features of his country. He was soon sensible of the imperfections of every plan of arrangement which had been previously adopted. He saw (what had been overlooked before), that the flower and fruit were the most noble parts of the plant, as well for ornament, as for their functions of reproduction; and he also saw that there was generally a similarity of the several members of flowers, and a general purpose indicated by the seed-vessel, whatever might be its external form or internal arrangement.

It was in 1560 that Gesner, fully convinced of the sufficiency of the permanent characters of the flower and fruit, submitted his idea of an arrangement founded on these organs. He sketched no plan himself; but his idea was not lost, for in 1583, Dr. Andrew Casalpinus, a physician of Pisa, and afterwards Professor of Botany at Padua, embracing the idea of Gesner, proposed a scheme of arrangement which has the fruit for its basis. This was the first attempt at systematic botany, and from which all other systems may be said to have taken their rise.

But it was soon discovered that the plan of Cresalpinus was inconvenient in botanical re- 
search. Much precious time was lost in waiting for the maturity of this organ; and all barren plants, especially exotics, which seldom ripen their fruit, would have to remain as nondescripts. "In summer, when plants are in their highest perfection, and the blooming face of nature invites to these innocent and pleasing enquiries, the student who would attain a knowledge of vegetables must not think of deriving it from a method founded on the fruit. Such a method will prove an insurmountable obstacle in his way; the season invites in vain ; in vain does inclination lend her powerful assistance; he cannot advance a single step; he becomes chagrined, and probably abandons it in disgust." (Bot. Lect.)

In methods founded on the flower, no inconvenience of this kind can exist. The class is mostly determined by that part of the flower which furnishes the leuding character; and it often happens that the fruit, though invisible, may be determined from some of the other parts of the flower already developed.

It was upwards of a century after the days of Cxsalpinus, the father of system, that Rivinus, of Leipsic, produced another revolution in the science, by proposing a method founded on the regularity and number of the petals. Thus, it appears that systematic Botany did notall at once attain that degree of purity and
perfection to which it has at this day arrived ร 2 
for many systems perished soon after they were projected: with Crsalpinus died his plan of arrangement; and about a century afterwards Dr. Robert Morison, of Aberdeen, availing himself of the ideas of Cresalpinus and the learned Rivinus, re-established scientific arrangements on a more solid foundation; and, instead of restorer, has been honoured as the founder of their systems.

Between Casalpinus and Morison many celebrated writers assisted to improve the science, and extend the knowledge of Botany. Among these we find Dalechamp, Tabernamontanus, Porta, Prosper Alpinus, Fabius Columna, two Bauhins, Gerrard, Parkinson, Marcgrave, Hernandez, Passæus, Aldrovandus, and Rheede, author of the Hortus Malabaricus.

Morison's Botany was not long in repute, and was only adopted by one subsequent Botanist, namely, Bobart, who in 1699 completed Morison's History of Plants, assisted by Dr. Blair, who wrote some botanical essays. Imperfect as his system was, it furnished many useful hints to Ray and Tournefort as well as to Linnæus. Ray published his first work in 1682, and a much improved edition in 1700 . He adopted Tournefort's characters of the genera, wherever his plan would permit. His general history of plants contains descriptions of 18,655 species and varieties. He wrs fol- 
lowed by Sir Hans Sloane, in his Natural History of Jamacia; by Petiver, in his British Herbal; by Dillenius, in his Synopsis of British plants ; and by Martyn, in his Cambridge catalogue.

A cotemporary of Ray, a German of the nane of Knaut, endeavoured to improve Ray's system, as Linnaus said, by inverting it; but without much success: he made many alterations but few improvements.

Another cotemporary, Dr. Hermann, Professor of Botany at Leyden, was more successful than Knaut. As at traveller in India, and at his station in Leyden, he not only added a great many new plants to the Leyden garden, but aware of the difficulties and inconsistencies of existing systems, made many valuable corrections and real improvements in systematic botany. He was followed by Rubbeckius the younger: and he(Hermann), seeing imperfections still lurking in his own scheme, set about revising it, when death put an end to his labours. He was succeeded by the celebrated Boerhave, who was no less solicitous for the enrichment of the Leyden garden, and the interests and advancement of Botany, than his predecessor Hermann had been. He arranged near 6,000 plants, cultivated in the Leyden garden, which he superintended for twenty years, and left it in the highest order to his successor, Dr. Adrien
Royen. 
From the foregoing brief notices of the progress of Botany, and of the authors who treated of it as a science, it is evident that every writer had the ambition of sketching a new system for himself: and certainly from the time of Crsalpinus to that of Linmæus many systems were projected which are now forgotten. And being no longer considered as legitimate science we have abstained from noticing many, or indeed any of them in detail. But as we are approaching a brighter era, and as Tournefort was one of these systematists who compressed into his own system several of the excellencies of his cotemporaries and predecessors, we may take a brief view of his system as an anticipation of that far more popular one which will be detailed in the sequel. 


\section{SYSTEMATIC BOTANY.}

Tив vegetable kingdom comprises such a vast number of plants, that it is alssolutely necessary that some plan of arrangement should be invented to collect into masses the many different tribes, in order to facilitate its study, ledge of the nature and virtues of the various products of the earth, which are proved to be, for the most part, so serviceable to man.

Plants appear to be naturally divided into three apparently distinct classes, namely, trees, shrubs, and herbs. We say apparently distinct, because there is really no well marked boundary betwixt trees and shrubs. A thriring shrub, growing in a luxuriant soil, is only al
small tree, and vice versâ. And moreorer there 
are many shrubs aud even herbs, which by their enflorescence and also by their inherent qualities, rank with the largest trees. These classes are therefore reducible to two only, namely, trees and herbs; and these are sufficiently distinct, not only from the texture of their stems, but also by the difference in their magnitude and durability.

Plants, however, are naturally dirided into genera and species. The first are families; the second are the individuals of the families. Again, there are affinities among the families, which when associated together are called groups. And, on the other hand, the species leave their specific character and degenerate into varieties.

The great dirersity of structure, of outward port, and constitutional peculiarities exhibited by plants, have been the cause of so many systems of classification having been propounded, to give the science something like a fixed character. But as neither the laws for identifying generic nor specific characters were previously fixed or universally understood, scarcely two systematists have hit upon or adopted the same marks of distiuction. The greater or more striking features of vegetation were admitted by all ; but in the details of classification much difference of opinion prevailed, which will appear by a compurison of the three systems about to be adrerted to. 


\section{SYSTEM OF TOURNEFORT.}

This was invented by Joseph Pitton de Tournefort, a French Botanist, and was studied along with that of our countryman Ray, until both were superseded by the Linnann system. 'Tournefort's system had a good deal of originality about it; and was at least ingenious. His method is founded on the presence, situation, figure, proportion, or absence of the corolla. This being the most imposing member of the flower, though no other is more liable to incidental variations, led almost all the earlier Botanists, as well as 'Tournefort himself, to give it an undue preference in the classification. On this score, therefore, it was to be regretted that he fixed on the corolla as a busis for his system. But still the plan was valuable, as it very much assisted succeeding
authors in the formation of their systems.

Ho divided the regetable kingdom into two 
grand divisions, namely, first, all such plants as are herbs; and, second, all those which are denominated shrubs and trees. These togethcr are divided into twenty-two classes: the first seventeen of which are herbs, and the other five contain trees and shrubs: these are again subdivided into one hundred and nineteen orders, but without proper names being applied to them. The characters of the orders are not always correct, as the distinguishing parts are not always present at the same time.

These anomalies rendered his system by no means convenient for the ready identification of new plants: but, notwithstanding this defect, it enabled him to bring together several of the natural orders, a result which was duly appreciated by his great successor, Linnæus, as well as by the equally great Jussieu, in his arrangement of the natural orders. In this light, Tournefort will always be respected as a Botanist who began a reformation which was reserved for Jussieu and his followers to complete.

As the greater part of his system is now almost exploded, it will be unnecessary to occupy our pages with obsolete matter : and, therefore, we shall confine ourselves to the numbers and names of his classes, to show his scheme, and to prove that it was really the origin of the Jussieuan system. 


\section{DIVISION I.-HERBS.}

CLASS I.-CANPANIFORMES.

Herbs having a simple, regular, bell-shaped monopetalous corolla. This class contains nine sections. We omit giving the genera, because some of them are doubtfully or mistakingly placed.

CLASS II.-INFUNDIBULIFORMES.

Herbs having a simple regular funnel, salver, or cup-shaped monopetalous corolla. This class contains eight sections.

\section{CLASS III.-PERSONATA.}

Herbs having masked flowcrs, simple, monopetalous, and irregular: the seeds contained in a pericarpium. This class contains five sections.

\section{CLASS IV.LLARITA.}

Herbs having lipped flowers, simple, monopetalous, and irregular: the seeds four, attached to the botiom of the persisting calyx. The sections of this class are four.

\section{CLASS V.-CRUCIFORMES.}

Herbs with cross-shaped flowcrs, simple, tetrapetalous, and mostly regular: the fruit a siliqua or a silicula. This clnss has ninc sections. 


\section{CLABS VI.-ROSACEI.}

Herbs having flowers resembling the rose, simple and regular, with from five to an indeterminate number of petals. This class contains ten sections.

\section{CLASS VII.-UMBELLATA.}

Herbs having their flowers disposed in an umbel, simple, pentapetalous, regular, and having two naked seeds attached to each other. The sections of this class are nine.

\section{CLASS VIII.-CARYOPHYLLEI.}

Herbs having flowers resembling the pink, simple, pentapetalous, regular: the claws of the petals long, and attached to the bottom of a monophyllus calyx. - The sections of this class are two.

\section{CLASS IX.-LILIACEI.}

Herbs having flowers resembling the lily, simple, regular, monopetalous, with the limb deeply divided into six segments, tripetalous or hexapetalous: the seeds contained in a capsule of three loculaments. This class contains five sections.

\section{CLASS X.-PAPILIONACEI.}

Herbs with butterfly-shaped flowers, simple, polypetalous, the fruit a legumen.-This class contains five sections. 


\section{CLASB XI.-ANOMALAE.}

Herbs having simple, polypetalous, irregular flowers, which do not conveniently arrange themselves in any of the other of these classes. The sections of these classes are three.

\section{CLASS XII.-FLOSCULOSI.}

Herbs with composite flowers, consisting of many tubulose, monopetalous florets, placed on a common receptacle: the stamens united by the anthers in the second, third, and fourth sections. This class contains five sections.

\section{CLASS XII.-SEMIFLOSCULOSI.}

Herbs having composite flowers, consisting of many nonopetalous, ligulate corollets, placed on a common receptacle, the stumens united by the antliers. The sections of this class are
two. CLASS XIV.-RADIATI.
Herbs having compound flowers, consisting
many monopetalous corrollets placed on a common receptacle: the florets of the disk tubulose, of the margin ligulate. The sections of this class are five.

CLASS XV.-APETALE. Herbs having stamens and pistils but no
corolla, the calyx being tle only part thut en- 
velopes these organs. The sections of this class are six.

CLASS XVI.-APETALE ET AFLORES.

Herbs having neither stamens nor pistils but only seeds on the backs of their leaves. This class contains two sections.

CLASS XVII. -APETALE ET AFLORES ET ACARPII.

Herbs having neither flowers nor apparent seeds. This class contains only two sections, and includes the mosses and fungi, as well as the algæ, and polypi, which the author believed to be vegetables.

\section{DIVISION II.-TREES AND SHRUBS.}

CLASS XVIII.-APETALA.

Trees and shrubs having stamens and pistils, but no corolla. This class contains three sections.

\section{CLASS XIX.-AMENTACE.E.}

Trees and shrubs having their male flowers, and some of their female flowers also, disposed in an amentum. 'This class contains six sections. 


\section{CLASS XX.- MUNAPETALE.}

Trees and shrubs having monopetalous, campanulate, or infundibuliform flowers. This class contains seven sections.

\section{CLASS XXI.-ROSACEI.}

Trees and slirubs having rosacious polypetalous flowers. The sections of this class are nine.

CLASS XXI1.-PAPILIONACEI.

Trees and slirubs having papilionaceous flowers, and legumenous fruits. This class con-
tains three sections. 


\section{LINNÆAN CLASSIFICATION.}

From the above faintly traced outline of the classification of Tournefort, it may be observed, that it was, in fact, the embryo of the natural system, sketched afterwards by the profound genius of its author. Tournefort was more fortunate in fixing the character of lis classes than in arranging his orders under them ; and seems to have been guided more by the ontward semblance of plants than by their internal and structural affinities.

But a day was approaching when the ingenious system of Tournefort, with all those of his predecessors and cotemporaries, were to be discarded and forgotten; and all the accumulated systematic knowledge of Botany-the results of ages of study, were to pass away like a morning cloud. A rising genius was then appearing on the horizon, who was destined to shed a brighter and more interesting light on 

the regetuble kingdom thun had before illu-
mined it.

$A$ belief in the sexuality of plants had been gaining ground from a very remote period; and about the birth of Linnæus was very partially credited, and soon after demonstruted as a certain fuct, by the experiments of that great naturalist himself.

As sexual distinction was most striking and definite umong animals; and as his own experience showed that the sexes were even exsepurately on the same plant, it occurred to his rivid inagination, whether or not these sexual distinctions would form a basis for a new systenı of Botany. was expanding in his mind: and when the prospect opened to him of how easily by the simple enumeration or position of the male and female parts of a flower, plants could be arranged into
classes and orders, he must hare enjoyed much
mental pleasure and gratificution. mental pleasure and gratificntion. And besides,
Linnaus could perceive that when he could.
mature and publish lis new mature and publish his new system, it would be received with eagerness, not only among prac-
tical, but umong amateur Botanists; beciluse quired, nor any irksome labour enjoined. His classes and orders, being for the most part 
numerlcal, were easily acquired; and their signification readily comprehended.

Whether or not he felt such impressions-it must hare been a source of the utmost satisfaction to him to witness how readily his new system was embraced in almost every part of the civilized world. The very circumstance (the sexuality of plants) not being everywhere known at the time gave an additional motive and impulse to inquiring minds, especially when the acquisition of scientific Botany was to be attained with so little mental fatigue.

The sexual sy'stem, as that now under consideration is sometimes called, was certainly the most siniple artificial method that could be invented for gaining an adequate knowledge of plants. For artificial it decidedly is, as was acknowledged by its author, Linnæus, himself. For before his death he had made some progress in forming a natural arrangement, which has been completed, as far as possible, by his successors. But, as his sexual system is still valued, and considered by many eminent men as an inviting and pleasing threshold to the science, "it

* "The experience" of nearly an hundred years has proved to cvery unprejudiced mind, that no systcm has appeared, which can be compared to that of the immortal Swede, for the facility witl which it enables any one, hitherto unpractised in Botany, to arrive at a knowledge of the genus and species of a plant."Sir W. J. Hooker. 
would be a serious defect in this our little work did we not present a faithful outline of the system of Linnæus.

Excellence is only apprecinted by conıparison, and the value of any ulterior scheme of clissification ulready made, or to be made, will only be esteemed by comparing it with what has passed, or is passing away. ber, proportion, and situation of the stamens, the male parts of the flower, and the pistils, consists of twenty-four classes, of which twentythree are flowering plants, and the twenty-fourth is flowerless, or at least has no conspicuous flowers. To each of these classes an indeterminate number of orders belong, and are
irranged as follow:-

\section{DIVISION I.-FLOWERING PLANTS.}

\section{CLASS 1. -MONANDRIA."}

Bissexual flowers having one stamen, aul containing two orders.

Order I.-Monogyniu.-Flowers having one style or pistil. Examples of Generu herein in-

* The termination andria and gynia (gyne), the female. 
cluded, Canna, Hedychium, Alpinia, Hippuris, or Mare's-tail, \&c. This order contains many beautiful, and several useful exotic plants; of the Genera, four are indigenous to Britain, namely-Centranthus, salicornia (glasswort), tostera (wrackgrass), and hippuris (mare'stail. We have chosen the mare's-tail for an illustration of this class, $P l .2$; $a$, flower magnified; $b$, rooting portion of the stem. This is one of the most simple among perfect plants. It is believed that it renders great service as a purifier of the putrid air of marshes, hy absorbing great quantities of inflammable air.

Periantheum inconspicuous; Stamen, a simple filament placed close to the germen, bearing a roundish anther of two lobes. Style filiform, simple; Fruit an achenium with a fleshy albumen.

Order II.-Digynia.-Flowers having two styles. This order contains seven genera already described in books; among which the callitriche (water starwort) is common in British ditches.

\section{CLASS II.-DIANDRIA.}

Bisexual flowers having two stamens, and containing three orders.

Order I.-Monogynia.-Flowers having one tyle. This order contains a great many genera, some of which have numerous species. Among 


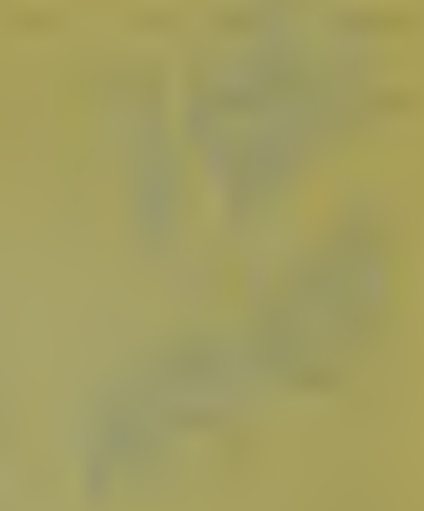




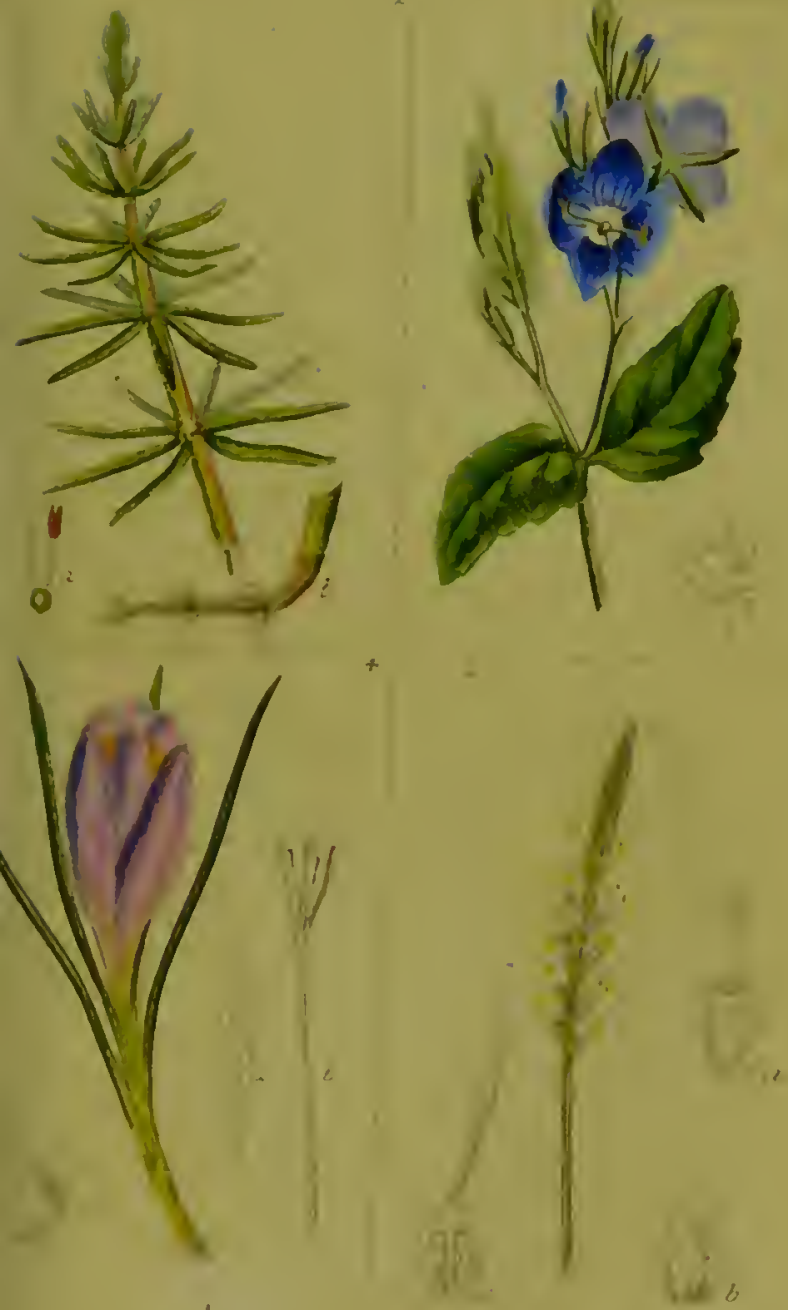

the genera we find the olive, the privet, lilac, and well known jasmine; and of one of the species of the genus veronica, we have given an illustration, (v. chamadrys), which was formerly used by physicians, in disorders of the lungs, $P l .3 ; \alpha$, ripe ovary and calyx. The extensive genus silvia belongs to this order, but it is thought improperly, because it is diandrous by abortion, the lower pair of the stamens being
absent.

Generic character. - Calyx, four to five parted; Corolla, somewhat rotate of four lobes, the fourth narrow (rarely tubular or gaping); Stamens, two inserted into the throat of the corolla ; Style, tliread-sliape; Stigma, round; Capsula, two-celled, inversely heart-shaped, many-
seeded.

Order II.-Digynia.-Flowers having two styles. This order comprises only three genera of grasses, chiefly natives of Europe. Among them, one is the sweet scented spring grass (anthoxanthum odoratum), which is supposed to impart the delightful aroma to new hay. OrDER III.- Trigynia.-Diandrous flowers,
but furnished with three styles. This order
contains only. two contains only two genera very nearly allied in qualities, namely, the pepper (piper), and pepperomia. They are both natives of the East and West Indies. The first being one of our most important articles of commerce, and universally used as a spice. 


\section{CLASG III. - TIIANDRIA.}

Flowers having three stamens, and divided into three orders.

Order I.--Monogynia.-Bisexual flowers having one style. This is a very large order, and contains a vast number of beautiful species. Almost all the splendidflowering Cape of Gond Hope bulbs are included here. The ixias, trichonemas, tritonias, gladeolusis, iriscis, \&c., are a few of the most esteemed. Our more familiar, and no less engaging crocus is worthily ranked in this order; an examination of the flower of which will convey a good idea of the general structure of the others. This class we have illustrated by the spring crocus (c. vernus), $P l .4 ; a$, anther; $b$, pistil ; $c$, roots and tuber.

This pretty flower is one of the first to make its appearance in the spring, and is a great enlivener of the parterre from February to April, and may indeed be said to be the herald of Flora's richly garnished train.

Say, what impels, amidst surrounding snow Congealed, the crocus yellow bud to blow? Say, what retards, amidst the summer blaze, The autumnal bulb, till pale, declining days ? The God of scasons-whose pervading power Controls the sun, or sheds the fleecy shower; He bids each flower his quickening word obey, Or to cach lingering bloom enjoins delay.

WHITE.

There are many varieties of the spring crocus, of which the purple is the most beautiful, 
though the yellow have a more showy ap. pearance in the gurden. It is a native of Ituly and Spain, and is found growing wild, with petals slightly tinged with purple at the buse, in some parts of Switzerland.

Generic characters. - C. Spatha of one lenf; Corolla, tube very long, limb regularly six-cleft; Stamens, inserted into the corolla, bearing erect arrow-shaped anthers; Style, filiforn, bearing a three-parted dilated stiginn; Capsula, three-celled, many-seeded; Seeds, somewhat globular.

Order JI.-Digynia.-Triandrous flowers having two styles. This is also a large order, and contains a principal part of the useful family of the grasses, from the invaluuble wheat, down to the puny hair-grass; and from the nutritious sugar-cane, down to the no less wholesome millet. It is, perhaps, the most important order of plants to be found in the vegetuble kingdom.

Order IIT.-Trigynia.-Triandrous flowers having three styles. This order contains above twelve genera, consisting of annuals, severul of which are aquatics, and perennials; all of which are small, and, except to the Botanist, worthless plants.

\section{CLASS IY.-TETRANDRIA.}

Flowers having four stamens of equal length, 
Order 1.-Monogynia.-'Jetrandrous flowcr's having one style. This order is notable for containing at great number of highly ornamental shrubs, chieffy from New Holland and the Cape of Good Hope. Among these, the banksias, proteas, and warratah (telopea), are pre-eminent. There are also many fine herbaceous genera. From among these last, we have figured one of the most common British plants to give an idea of a tetrandrous flower, $P l .5$, the greater plantain ( $p$. major), $a$, is a flower magnified; $b$, ovary when fully ripe; $c$, ovary cut perpendicularly with the pistil attached, showing the seels upon the centre receptacle.

This is a very common plant in England, and its seeds are favourite food for linnets, finches, and many other of our smaller birds, and its leaves are much esteemed for their virtiles when applied to wounds.

Generic characters.- Plantago.-Flowers in spikes or heads; Calyx, four-cleft ; Corolla, superior, rotate, in four parts, persisting; Stamens, elongated; Style, simple ; Capsula, cut round, two-celled, from two to four seended.

OrDER II.-Digynia.-Tetrandrous flowers lhaving tuo styles. This order contains only four genera as appears by the latest published lists. The witch-hazel (hamamelis), a North American deciltuous tree, belongs to this order: the others are inconspicuous plants.

ORDER III.- Tetragynia.-This order con- 
tains tetrandrous flowers having four styles. It appearing that Linnacus discovered no tetrandrous flower having three stylet.

The principal genera of this order are the well known lolly (ilex), a British tree, and the equally common pond-weed (potamageton), also a native of this country. $\Lambda$ few other British annuals, as the pearlwort (sagina), and the allseed (radioln), also belong to this order.

\section{CLASS V.-PENTANDRIA.}

This extensive class associates all flowers having five stamens, and is divided into six orders.

Order I.-Monogynia.-Contains pentandrons flowers having one style. This is one of the largest orders in the sexual system, and consists of every description of tree, shrub, and herb, natives of every yuarter of the glohe. Here are lofty timber trees, useful fruits and drugs, and flowering plants of matchless benuty. We may name a few of the genera to show the importince of this class and order to Botanists, and to mankind in general. Mirabilis, heliotropium, primula, cyclamen, dodecatheon, phlox, brugmansia, ipomaa, convolvulus, epacris, azalia, plumieria, solandra, solnnum, portlandia, campanula, lobelia, caprifolium, gardenia, vitis, riola, ribes, heliconia, strelitzia, musa, dzc.

ORDER II.-Digynia.-Pentandrous flowers 
having two styles. This is also a large order, and contains many useful herbaceous plants as well as handsome flowers. We have figured one of the species of a very interesting genus; namely, dwarf gentian, (gacaulis), $P l .6 ; a$, a portion of the corolla with the five stamens; $b$, pistil.

This is termed gentiana acaulis, that is, stemless gentian, because in its natural state, it has no stalk; by cultivation, however, it is made to throw up its corolla on a kind of stem. "This is the species best known and most admired in the garden, on account of the brilliancy of its blue, which is equal to the finest of the metallic blues. The corolla is very large for the size of the plant, therefore it has a fine effect when planted in large clusters; and it demands adniration when viewed singly, as the lower part of the interior of the campanula of the flower forms a fine spotted yellowish star on the rich azure blue ground of the five expanding segments of the corolla, whilst the exterior of the bell is of reddish purple, or deep lilac." - PHiLuips.

Generic characters.-Gentiana.-Calyx, bellshaped, four or five cleft ; Corolla, somewhat bell-shaped, four to five cleft, the throat naked or bearded; Stamens, inserted into the tube of the corolla; Styles, at first connate, afterward separate, bearing obtuse stigmas; Capsula, one-celled, with two valves at the npex; Seeds, emarginate. 



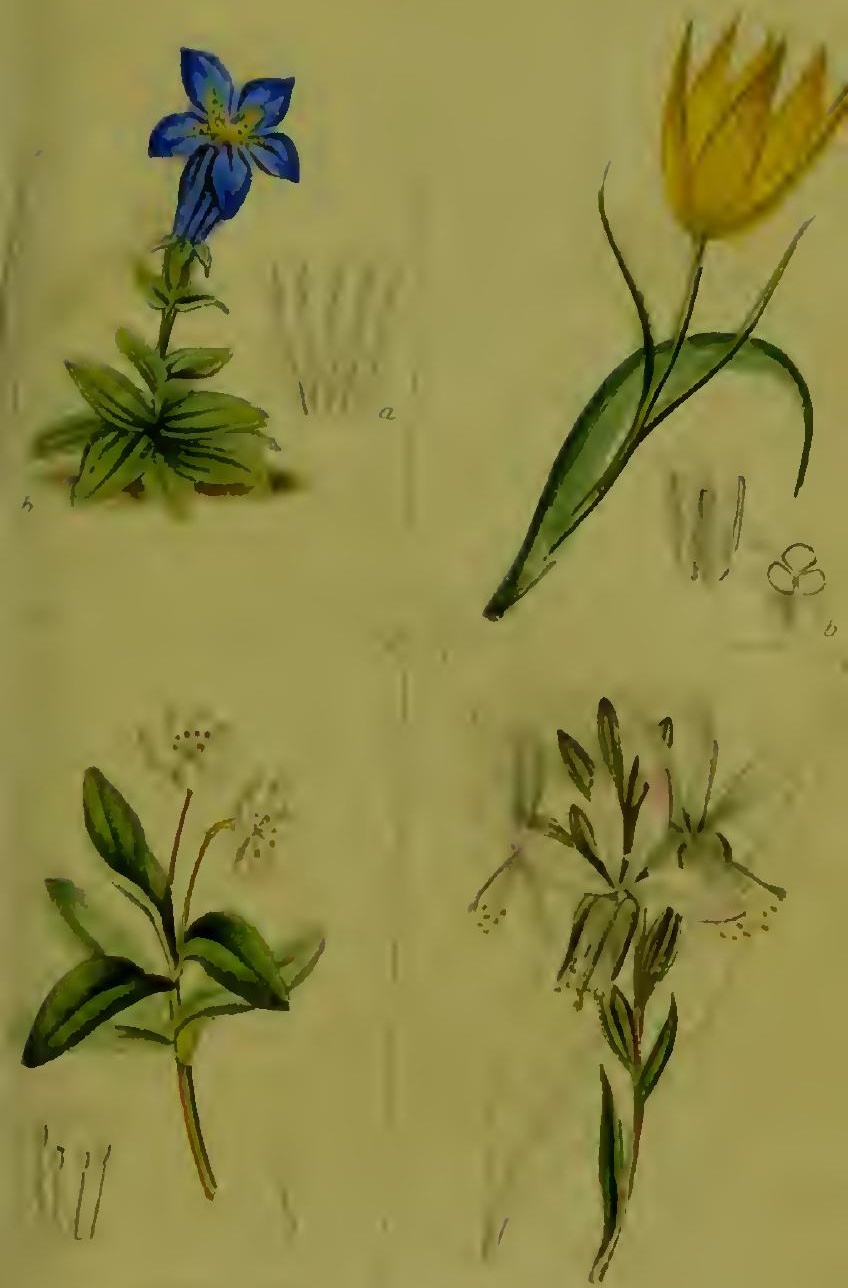

Order III.-Trigynia.-Contains all pentandrous flowers having three pistils. Here are brought together some fine ornamental and useful shrubs, as the viburnum, rhees, dec., as some economical and medical herbs.

Orner IV.- Tetragynia.-Pentandrous flowers having four pistils. Linnæus, it seens, could find but one genus to be placed here: the type of which is a small bog plant, called in England grass of Parnassus (Parnassia palustris).

Order V.-Pentagynia.-This order contains pentandrous flowers laving five styles or pistils; and in which are arranged some very beautiful and showy exotics; such as the larochea, kalosanthes, and crassula, three very nearly allied genera. Here is also the economical flax (linum), and the curious sundew (drosera), \&c.

Order VI.-Polygynia. - Pentandrous flowers having many pistils. This is a small order, three genera only being associated in it, numely, migosurus, mousetail, ceratocephalus, and Xanthorhiza, yellow-root. The last is a low North American shrub, the two first diminutive
annuals.

CLASS VI.-HEXANDRIA.

Flowers distinguished by having six stamens orders.

Onder I. - Monogynia.-Hexandrous flowers 
having one pistil or style. This, though chiefly' consisting of tuberous and bulbous herbs, may be truly called a splendid order. It comprises most of "the lilies of the field," namely, narcissus, amaryllis, pancratium, crinum, dec. It also contains that king of fruits, the pineapple (ananassa), together with the aloes, tretillarias, dc. As a type of these interesting and elegant blossoms, we give a figure, $P l .7$, of the wild tulip (t.sylvestris), to convey an idea of the general structure of the flowers of this class and order; $a$, stamens and pistil; $b$, ovary, cut transversely to show the ovules.

Generic characters.-I Iulipa.-Calyx, of three coloured sepals, bell-shaped, deciduous ; Petals, three, close within the sepals, and, like them, coloured, naked below; style, none; Stigma, three-lobed ; Capsula, three-sided, three-celled, three-valved; Seed, compressed.

Order II.-Digynia.-Hexandrous flowers having two pistils. This order contains only three genera, one of which is the invaluable rice, the bread-corn of India, and one of the grasses. The others, though curious, are worthless plants.

ORDER III. - Trigynia.-Hexandrous flowers having three pistils ; except one genus of palm (sabal), and a few bulbs and tubers belonging to melanthace, the plants in this order are not of importance. The genus rumex, the dock, constitutes a principal part of the order. 
Ornen IV.-Polygynia.-Hexandrous flowers having many pistils. This is a small order, comprising only four genera, most of then aquatics. The most beautiful of all British plants, as the opinion is, belongs to this order, namely, the water plantain (alisma plantago), conmon in every secluded pool.

\section{CLASS VII.-HEPTANDRIA.}

Consisting of flowers having seven stamens. Divided into four orders.

OrDER I.-Monogynia.-This order contains all flowers having seven stamens and one pistil. The most conspicuous plants are the horse-chesnut (Esculus), and the red flowering ditto (Pavia). Some of the latter are slirnbs; and the other trees of the order are African fruits, called by the African name Parinarium. One of the British herbs belonging to the natural order Primulacea, we liave figured on $\mathrm{Pl} .8$ : it is commonly called the oval-leared winter-green (Trientalis Europoea), and is found in moist woods.

Generic character.-Trientalis.-Caly.x, seren cleft ; Corolla, in seven parts, spreading, segments oval-lance-shaped; Stamens (a), filaments awl-shaped, inserted into the base of the corolla, anthers oval; Style (b), simple, stigma headed; Berry, like a capsule, dry; Placenta, central und free; Seed, angular, several.

Order II.-Digynia.-Consist of heptan- 
drous flowers, having two pistils. This order contains a single genus, namely, the Limeun Africanum, a herbaceous perennial found at the Cape of Good Hope.

Order III. - Tetragynia. - Heptandrous flowers having four pistils. This order contains only two genera. The first is an American aquatic, called Lizard's-tail (Saururus); and the other is a Chinese shrub called Astran. thus.

Order IV. - Heptagynia. - Heptandrous flowers having seven pistils. This order contains only one genus, namely Septas, of which there are three species, natives of Southern Africa. This genus is appropriately named, as all the members of the flower are divided in to seven.

\section{CLASS VIII.-OCTANDRIA.}

Flowers having eight stamens. This class consists of four orders, namely,

Order I.-Monogynia.-Octandrous flowers having one pistil. An order comprising a numerous tribe of ornamental trees and shrubs. Among many others it contains the almost endless genus of Erica, or heaths. Of this single genus there are above six hundred species described, besides many varieties. Here are also the Ænothera, Fuschia Daphne, Combretum, Vaccinium, dec. We lave given a 
fignre of that curions flowering genus Gaura, as a type of the class and order. See Pl.9, which represents the Gaura biennis.

Generic character.-Gaura.-Calyx, tubular, four-cleft, and deciduous; Petals, generally four; Stamens, inserted into the calyx, filaments awl-shaped, anthers incumbent and oval; Style, simple, stigma four-cleft; Nut, four-sided, one to two-seeded.

Order II. - Digynia. - Containing octandrous flowers having two pistils. This is a small order, comprising only five genera, and, except the Weinmannias, which are West Indin shrubs, no others require notice.

ORDER III. - Trigynia. - Octandrous flowers having three pistils. This order is ellriched by the genera Coccoloba and Sapiradus; some of the species of which yield good fruits. The genus Polygonum occupies a large space in the order: but except the P. Figopyrum, which is agricultural, and two or three species which are used by the dyer, a great miljority are only weeds.

ORDER IV.-Tetragynia.-Octandrous flowers having four pistils. This order contains only six generu, and are all much more curious than either beautiful or useful. The Bryophyllum is curious in bearing its flowers on the edges of the leaves. Paris and Adoxa are neat little British herbs, found under damp woods or hedges, and the Kalanchoc tropical underhrubs are no less curious. 
CLASS IX.-ENNEANDRIA.

Flowers having nine stamens. This class contains three orders.

Order 1.-Monogynia.-Enneandrous flowers having one pistil. Here we find some of the most ormamental as well as the most useful trees of the torrid zone. The delightfully aromatic cinnamomum, whose young bark is so valuable a spice, with its congenerous species yielding cainphor and cassia, and from which many useful condiments and drugs are prepared. The genus cinnamomum was established by Dr. R. Brown, and separated from the old genus Laurus, of Linnzeus ; a separation sanctioned as much by superior qualities, as by a difference of structure of the flower. Some of the genus Lanrus yield useful timber; and another genus, formerly united with the Laurina, yields the fine West India fruit called the Alligator pear. The major part of the order are lofty trees or shrubs: but two of the genera are herbaceous.

Order II.-Trigynia. - In this order all flowers having nine staminas and three pistils are arranged. But Linnæus, it seems, could find only two genera which belonged to it, namely, the well known Rhubarb (Rheum), and a Carolinian plant called Pleea, a rushlooking plant. The rhubarb is now no less valued as a culinary, as it was formerly as a 


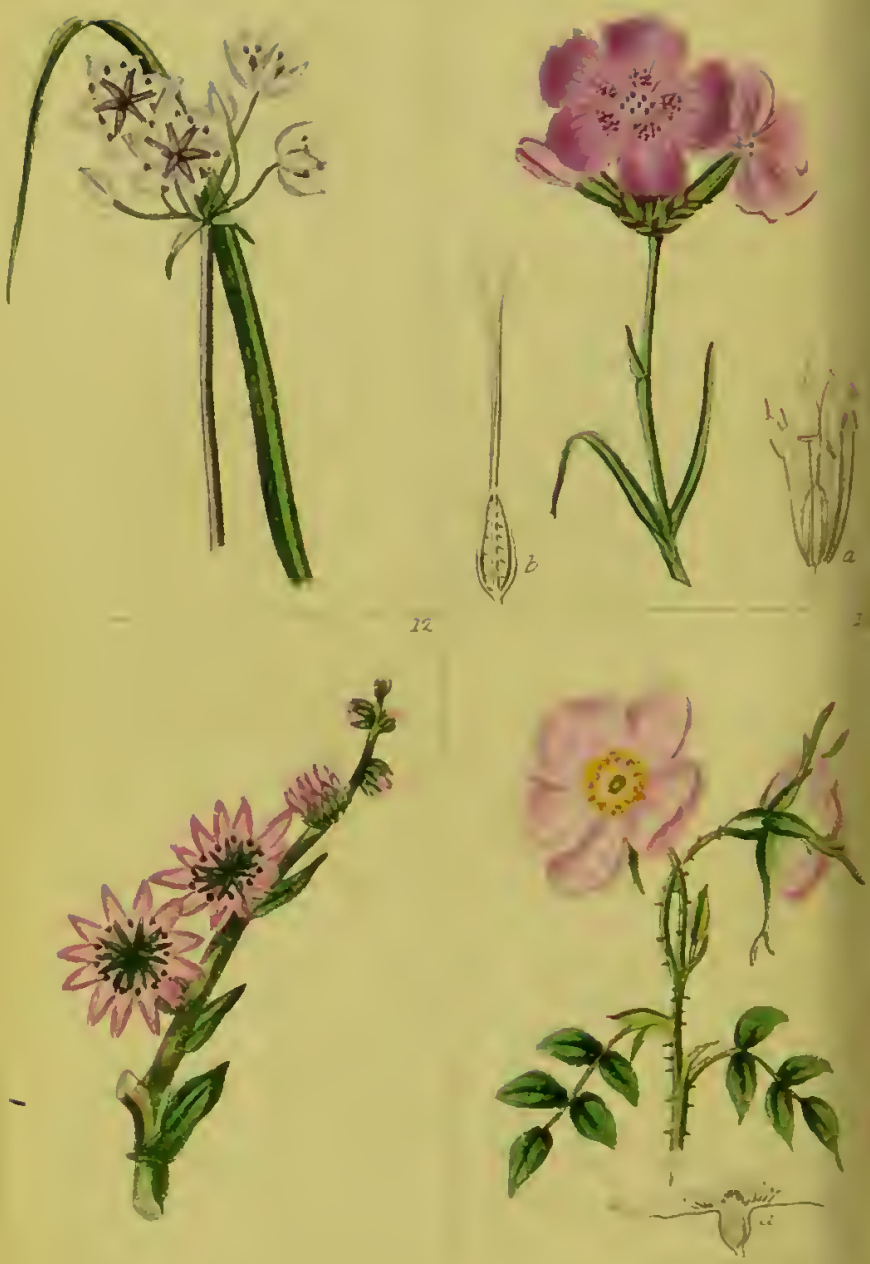


medical plant. In the shape of pies and tarts it is on every table, from the palace to the cottinge. Few regetables unite the two excellencies of nutritious food and mild medicine so intimately as is found in well-cooked rhuburb: and few appear to be so susceptible of improvement in gaining varieties of larger growih and milder qualities.

OrDER III.-Hexagyniu. - Flowers laving enneandrous flower's, with six pistils. And of this character there happens to be but one solitary genus, and with only one other congener in the vegetable creation. Of this lone genus, Butomus, there ure two species; one Nepalese, and the other (B.umbellutus) is a British plant, called the flowering Rush, ind of which we have given at figure, $P l$. 10 . It is not uncommon ; and nsually found growing in ditches cut across low meadows near rivers. It is one of the most beutiful British plants; but the edges of the leares are so shirp that they cut the mouths of cattle that browse it: hence its generic name.

Generic characters.-Butomus.--Flowers in an unbel; Caly.x like a corolla, of six sepals, decaying; Stamens perigynons, filaments awlshaped; anther's oval and two-celled; Capsule six-celled, follicular, many-seeded.

$$
\text { CLASS X.-DEcaNDRIA. }
$$

All plants bearing flowers furnished with ten 
stamens belong to this class, which is divided into five orders, namely,

Order J.-Monogynia.-Decandrous flowers having one style. The glories of this order are the incomparable Kalmias and Rhododenrons, the Ledums and Andromedas, ull North American shrubs; besides the Arbutus of Europe and the Melastomus of India, with many other interesting genera. There are a gond many plants in the fifth and eighth classes that are nemly ullied to some of the genern in this; but the number of the stamens only harc caused their separation. Linnaus was often compelled to form incongruous associations, and no doubt against his orn judgment, in order to be consistent in his plan.

Orner II.-Digynia.-Here are placed all plants bearing flowers having ten stamens surrounding two pistils. In this order we have the handsome lamily of African shrubs called Royena, in honour of a director of the Botanic Garden at Leyden. There is also the Hydrangea so common in our court-yards; and the numerous genus Saxifrage, with its varieties, mostly hardy European plants. But the largest genus is Dianthus, which includes many of our sweetest and most esteemed garden lavourites. Every species is rendered more or less interesting, by the delicate forms and colours of their blossoms. Fven the most minute have u gay sparkling appearance, and the cultirated 
rarieties of the clove are as stately as they are beautiful. We add a figme of one species, namely, the Carthusian Pink (Dianthus Carthusianorum), to show the general structure of the flowers, $P l$. 11; $\iota$, stamens and pistils divested of the petals; $b$, pistils cut perpendicularly, to show the position of the ovules upon the central placenta.

The habits of the species are so well linown they hardly require description. 'They are all dwarf fibrous rooted lierbs, sending up slender jointed stems, crowned with one or more Howers. Generic claracters.-Calyx tubular, five-toothed, witl inbricated sciles at the base; Petals clawed, mostly toothed or nuch divided, seldom whole; Stamens inserted into a ring enbracing the seed ressel; Filaments lite hatis, Anthers two-celled; Style threadshaped; Stigmas laterally attached; Capsule one celled, many-seeder, placenta central, free.
Natural order, C'aryophyllacec.

Ordra III. - Decandrons flowers having
ree pistils. This order three pistils. This orler contains not many genera: but there are two pretty extensive ones, namely, Silene and Arenaria; both these elegant; but they are inconspicuous plants;
and many of then are nere weeds. The Stel-
laria, which enlivens our hedres. laria, which enlivens our hedges in May and June, with its numerous white sturlike blos-
.I 
soms, also belongs to this order; as well as the stinging Barbadoes cherry (malphigia), whicl are South American trees and sliruls, a few others are tropical climbers, and excellent timber are aliorded by the genus Erythoxylon, or red wood.

Order IV.-Pentagynia.-Flowers liaving ten stamens and five pistils. In this order we find the Averhoa, Spondius, and Buchania, tropical fruits; and Cotyledons or navel worts under shrubs; with the stone-crop (Sedums), and the handsome wood-sorrel (Oxalis); all of which are interesting to the Botanist.

Orner V.-Decagynia.-All plants bearing decandrous flowers, and having also ten pistils, belong to this order. But Linnaus it seems could discorer but one genus to constitute the order, and this is a tropical herb called $P$ hytalacca, of some value as an esculent regetable; for its juice as yielding a fine carmine colour; and for its medical qualities. It is the American Poke, the Pocan of Virginia. It is cultivated in the South of Europe for colouring wine.

\section{CLASS XI. -DODECANDRIA.}

This class comprises all plants whose flowers have twelve stamens surrounding oue or more pistils.

Hitherto the titles of the classes lave been in accordance with the number of stamens. But in this there is discordance, inasmucli as 
this eleventh cluss is known by having twelve stamens. The fict is, that no flowers are known to have exuctly eleven stumens. This cluss is divided into six orders, namely,

Ornen I. - IOnogynia. - Flowers haring twelve stimens and one pistil. In this order above thirty-fire genera of trees, shrubs, under. shrubs, and herbs are associuted, among which there are some fine flowering shrubs; one genus, (Garcinia mangostuna) yields delightfnl fruit; an esculent salid plant the purslane (P'orlulacu sativa); and one of our handsomest native flower's, met with on the banks of rivers, namely, the Purple willow-herb (Lythrum salicaria).
Except two species of this list, and the asara-
baccil baccil (Asaim Europoum), a hardy medical herb, ill the other generil and species are
exotics.

Ornzr II. - Digynia. - Contains flowers having twelve stmmens and two pistils. There ire only two genera, one a Botany Bay shrub, called Calicoma, and the other a perennial herb, one species of which is the British Agrimony, a inedical plant very common on the sides of fields and high roads.

OnDER III. - Trigynia. flowers huving three pistia. - Dodecandrous are four gelleris three pistils. In this order there the usefuldyers' one of which, Resella, contains to Britain and adnired mignonette fragrant and universally senus is the remark ( $R$. Odorale). Another Sents is the remarkably grotesque Euphorbia, 
of which the most striking spccics are tropical; many are European, and there are as many as fourteen found in Britain, where they are culled spurge.

Order IV.-Tetragynia.-Contains dodecan. drous flowers having four pistils. This order comprises one genus only, namely, the calligonum (C. Pallasia), a plant found on the shores of the Caspian sea.

Order V. - Pentagynian. - Dodecandrous flower's having five pistils. 'This is a small order, three genera only being ranked in it. The principal is the Blackwellia, East Indian evergrees shrubs, introduced into British collections about 1820 .

Order VI.-Hexagynia.-Flowers having twelve stamens and six pistils. One genus only establisles this order; and but one species lias yet been found of it, namely, the ceplatotus (C. fullicularis). It is a New Holland aquatic or hog-plant, its leaves being furnished with beatifully shaped pitchers with lids attuched to the apices.

Orner VII. - Dodecagynia. - Includes all plants whose flowers have twelve stamens and twelve pistils or styles. This is also a small order, it containing only two genera, namely, Monanthes polyphylla, a native of the Canaries, so named by tlie late Mr. Haworth, because they present but one flower at a time. The other genus is the sempervivum of Linnats, the houseleek of English Botany. Generic charac. 
ters.-Calyx in from six to twelve parts; Petals from six to twelre, lance-shaped, with scales at bottom; Stamens seated below the gernen; Stigmas acute; Copsules six to twrlie, inany seeded. Nat. ord. C'rassulacece: I'l. 12 , is a figure of the common houseleek (Semperivum tectorum).

Althougl this order like the preceding is designated by the number of the stamens, and particulurly the number of the pistils: yet allowance must be made for variations in the numbers of both; for it often happens that the numbers are more or less.

\section{CLASS XIJ.-I COSANDRIA.}

All plants having tuenty or more stamens inserted into the caly $x$ belong to this class. 'The generic churacters are C'alyx hollow, of from five to ten sepals; Corrollu of five petals inserted inlo the calyx; Stamens twenty or more, also inserted into the caly $x$, and often on a prominent ring. This class contains firo orders, namely,

URDER I.-Monogynia. - Icosandrous flowers having one pistil. 'This is a inost important order not only as containing the curious and splendid flowering cuctae, bnt becuuse it comprises a great number of our most useful fruits. Besides the gnava, eugenia, pomegranale, and almond; there are ulso the peach, nectarine, apricot, plum, and cherry: 
OrDer II.-Dipentagynia.-Flowers having twenty or more stumens inserted into the calyx, and surrounding two pistils. This order also contains somp excellent fruit trees, such as the pear and apple, the medlar, quirce, and Chinese loquat. It also contains the lirge genus mesembryanthemum, consisting of above three hundred species alleady described. This last is commonly called the fig-marigold, from the fleshy appearance of the calyx surmounted by the radiate petals.

ORDER III.-Polygynia.-Icisandrous flowers laving many pistils. This order is dignified by the presence of the lovely genus rosa, of which the species and varieties are innumerable. We give a figure of one that is seen in every hedge-row, namely, the common dog-rose (Kosa canina), Pl. 13 ; $\alpha$, a perpendicular section of the frnit to show the stamens seated upon the calyx. The generic characters of the rose are as follow: Caly.x with a pitcher-shaped tube, turbinate and persisting, limb five-cleft, divisions often pinnified or winged; Petals fire; Stamens many, inserted into the neck of the calyx; filaments like threads; anthers twocelled. Styles sereral, somewhat lateral, or free, or united in a column ; Stigmata headed. Tube of the calyx becomes a ressel containing the seeds fixed to the sides.

No plant is more regarded than the rose, nor has any plant called forth the skill and in. 
dustry of the florist more than this. There are in cultivition above twelve hundred species, and varieties; for since the Asiatic rose's have been introduced and united by cross impregnation with old sorts, there are now varieties out of number.

Besides the rose, there are several other farourite flowering plants, both shrubs and herbs, in this order, such as the calycan thus and chimonanthus, green-house shrubs; and geums and potentillis, herbs ; together with that excellent fruit-bearing herb, the strawberry.

\section{CLASS XI11. - POIYANDRIA.}

Flowers having many stamens inserted in the receptacle. It is here to be observed that the station of the stamens is the circumstance which distinguishes this class from the precelling: as the actual number of stumens is not to be regarded.

'This cliss contains six orders, namely,

Orner I. - Monogynia. - This order includes ull flowers having many stamens seated on the receptacle, and having in the miclst one pistil.

There are many fine showy flowering plants in this order, but the common poppy (Pupaver), being so familiary known, may be pointed to as a good type of the Howers of the whole. IF have also here the splendid water-lilly ( $\mathrm{N}_{y m}$ -
phoea), the lagerstramia, and the numerous 
family of Rockrose, one of which (Cistus albiflorus) we lave figured in $\mathrm{Pl} .14$; a, stamens and pistil, divested of the petals and calyx, to show the stamens seated upon the receptacle. This figure with the following generic characters will conrey a pretty good idea of the genus cistus:- Calyx of five somewhat unequal sepals; l'etals fire, below the germen, and deciduous; Stamens below the germen, erect, filaments hair-like, anther's roundish; Style thread-like, stigna headed, calpsule united to the calyx, fire-celled, five-ralved, separating in the middle; Seeds angularly oval.

There is also in this order the extensice family of Helianthemm or sun-rose, being small shrubs or under shrubs, mostly natives of the south of Europe.

Order lI.-Digynia.-Contains polyrandrous flowers having two styles. One of the most conspicuous flowers in the garden, namely, the peony (Pconia) belongs to this order. This plant is, however, very subject to variation in the number of its styles, having often more than two. From late introductions of many new species and rarieties of peony from China, Siberia, and elsewhere, our stock of them is much enlarged: and it is probable that the Chinese have many more varieties still to be looked for. The Fothergilla and Curatellu are also in this order. 



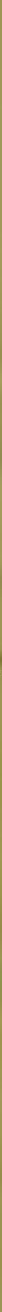

OrDCR III.-Trigynia.-In this order all polyandrous flowers having three pistils are ranked. The eximples are Hibbertia, Delphinium and Aconitum. It is remarked of these three genera that they are not constant in the number of their styles. 'The larkspurs (Delphinium) are a handsome fanily of border flowers, whether annual or perennial. 'The wolf's-bane (Aconitum) are ulso ornamental, but possess dangerous qualities. The very common monkshool (A.napellus) is one of the most poisonous plants in our gardens.

Orneu IV.-Tetrayymia.-Polyandrous flow. pls having four pistils. This is a small order, containing only two genera, namely, the butternut (Caryocar nuciferum), of which there are three species, and the drimys winteri, a medicinal plant. The nuts of the caryocar are sold in the London mirkets, under the nane of swuarrow nuts. All the species yield eatible unts, and the nuts of Caryocar butyrasum abound in oil, little inferior to that of the olive.

Orner V.-Pentagymia. - In this order we have polyandrous flowers having five stamens. This is not an extensive order; but a very con. venient type of it is in every garlen, and in some parts of the country in every hedge-row, namely, the columbine (Aquilegia vulgaris). The fennel-flower (Nigella), a common annual in the flower garden, also belongs to this order, 
and may be referred to as a type of the class and order.

Onder VI.-Polygynia.-l'olyundrous flowers having five pistils. This order consists chiefly of ornamental plants; some of which are valued for their magnificence, as the nelumbium or sacred bean, and the magnolias, $\mathbb{E}$., and many for their early and gaudy appearance, as the hepatica, anemone, dc. Some of our finest arbour plants also belong to this order, as the atragene, and clematis ; and the extensive and varied genus of ranunculus is also here. The winter aconite (Eranthis hyemalis), which bedecks our Hower borders so early in January with its yellow blossoms, is one of the genera; together with its congeners, the lielliborous, caltha, dec. It is remarkable that the plants of this, as well as a majority of those in the preceding order, are cliarged with hurtful or noxious qualities; they contain an acrid juice which is disrelished by, and injurious to all animals.

We liave now arrived at that point in Linnæan Botany at which the classification by the numbers or stations of the male and female or. gans ceases, and where other circumstances are chosen to identify the classes and orders which follow.

\section{CLASS XIS.-DIDYNAIIA.}

This class is known by having flowers of 
both sexes furnished with four stamens, two of which are longer than the other two. 'This dillerence in the length of the stamens is sufficient to identify the plants of this from those of the fourth cliss, which have fonr stamens of equal length. This cluss is divided into two orders.

Oruer I.-Gymnospermia.-This order contains all plants agreeing with the character of the class, and having their seeds situated at the bottom of the calyx instead of a capsule.

This order is extensive, and comprises a great many very common herbaceous plants, such as the bugle, cut-mint, lavender, mint, ground ivy, horehound, \&c., any of which are typicil of the whole. Severil of the genera are. sulfruticose, that is half-shrubby, such as the phlomis, the thyme, and lavender, and most of them are frigrant, and much used in salads and cookery as well as in medicine.

Onnfir II. - Angiospermia.-This order lins didynamous flower's, but is easily distinguished from the first order, by having the sereds con. tained in a capsule.

It is a large order, and conlains many beantiful flowering shrubs and herbs. The bignonias, teconas, gloxinia, pentstemon, thunbergia, verbena, clerodendron, digitalis, ec. Of the last named genus we subjoin the generic cha-
racters.

Caly,x, five-cleft, persisting, segments un- 
equal ; Corolla somewhat bell-shaped, bellying, limb abbreviated, upper-lip very obtuse, or cleft, lower-lip trifid, middle seginent eqmal with the others or stretched out; Stamens, shorter than the corolla, anthers with irregular cells; Style persisting; Stigma two-lobed; Capsula oval, two-celled, many-seeded, placenta thick and central, valves none; Seed rough, or punctate.

We gire a figure of the purple fox-glore ( $D i$ gitalis purpurea), $\mathrm{Pl.15}$; a, a portion of the corolla with the stamens; $b$, pistil; $c$, horizontal section of the ovary. This figure also shows the didynamous (twinned) position of the stamens; but we should wish our young friends to

\section{"Explore the Fox-glove's freckled bell "}

for themselres. It is a beautiful, but a baneful plant; it is one of the richest ornaments of our hedge-rows and wood-sides. It enthellishes the shrubbery with its spikes of pendant flowers, hanging from their spire-like branches with a grace and elegance pcculiar to them. "Ithen these flowers advance from the calyx, they are securely closcd at the end by the four clefts of the corolla, which meet so exactly as to prevent the admission of air, until the parts of fructification have arrived at maturity, at which period the lips of the flower burst open in a bell or trumpet-shape, displaying the beantiful leopard 
spots of the interior of the flower. In this state the corolla remains for some days, until the anthers have discharged their farina, when the mask drops off, that the sun may more readily ripen the seed-ressels." As this plant contimues to open fresh flowers for a long time, its beats is perpetuated for a more lengthened period than most other flowering plants.

\section{CLASS XV.TTETRADYNAMIA.}

This class contains bisexual flowers, furnished with six stamens, four of which are longer than the other two, and which distingnishes this from the sixth class already noticerl.

The flowers of this class are known by having a tetraphyllows perianthium: the Leuflets orato-lance-shaped, concave, and convergent, equal and deciduous; Corolla is of four petals, seated on the receptacle, a little longer thin the leaflets or sepals of the calyx, the limbs assuming a crucilorm position, plane and widening outwards, mostly blum, sometintes malginate; Stamens, filaments six, awl-shaped, the two opposite ones shorter than the other four, the anthers pointed, often arrow-slaped, diverging; inside the slort filaments are two glinds; Pistillum, germen superior, style short or wanting, stigma obtuse, coinmonly hemispheric; Pericarpium, a siliqua or silicula of two ralves, mostly two-celled, opening 
at the base; the Stigma is commonly persisting, and forms the apex of the dissipiment (that is, the partition between the cells), extending beyond the valves of the siliqua; Seeds roundish, "pproaching in some instances to a kidney shape, attached by the umbilicus to the edges of the dissipiment, which is prominent beyond the margins of the valves.

The orders of this class were two, distinguished by the form or length of the seed-ressel in the early Linnzan schools; but those distinctions are now dropped, the whole of the plants being arranged under the classical title.

The class contains a grent many common, bnt both useful and beautiful plants: among the latter the garden stock is conspicuous: and even the wall-flowel is esteemed. As this is one of the best known, we give its generic chiracter. Calyx, shut up; Seed-ressel is siliqua crowned by a two-lobed, or capitate stigma; Seeds in one series, compressed and margined. In $P l .15$ we give a figure of the $W^{\text {all-flower, }}$ (Cheiranthus ('heiri, rar. ferrugineus); $a$, stamens and pistil; $b$, a ripe silicle, showing the dissipiment with the seeds attached.

Here we have also the early flowering Arabis, Alyssum, the Iberis or Candytuft, \&c. The useful plants are all the Cabbige tribe (Brassica); the Mustard (Sinapis); Sea Kale (Crambe); Radish (Raphanus); together with all the different sorts of cress. 


\section{CLASS XVI. - HUNARELPHIA.}

This class comprises all flowers having one set of united stamens.

'The corolla is of fire petals, and mostly regular, each petal having one murgin under and one above its neighbours.

The class contains eight orders, founded on the number of the stamens. And here it maly be observed, that in this system the orders are founded on the number of the pistils in the first thirteen classes only, all the others being founded on other circumstances. In this and the two following classes, the orders are very "ppropriately named from the class's to which the indiriduals of them would have belonged, but for the circumstance of the filaments being united.

This shows how intimately Linnæus had studied his subject, and what care he took to make it harmonions whole.

Ornea I. - Triandria. - Flowers having three stamens united at the base into one brotherhood; and which brotherhood confines certilin genera here, which would have been more miturally placed in Triandrit, the third class; because it is evident, that the membrane which unites the filaments together, is a tubulose investment of the germen, and not the dilated bisis of the filaments themselves. Linnicus, howeser, on the plan proposed by him- 
self, placed several generit here, which should have been elsewhere. These generia are ferraria, tigridia, galuxia, and others; all bulhous, or rather tuberous stemmed plants, bearing handsome flowers; and which rank among what are called Cape luibs.

Order II.-P'entandria.-Containing flowers having five slamens united in one set or brotherhood.

In this order we lave the genera lermannia, mahernia, erodium, and other interesting plants: but the most admired and conspicuous gellu: is the passion-flower (passiflora), with its many gorgeous species. The tasconia, a genus nearly related to passiflora, is also here, as well as their congener, the murucaja. This last, like one of the passion-flowers, yields esculent fruits, which are fragrant and refreshing.

Order II1,-Hexandria, -Includes flowers haring six stamens united in one set. Only one genus has yet been found to constitute this order, and that is a small narrow-leaved plant, a native of Sonth Americn. This genus is the gillesia graminea, a bulbous herb, but which is neither useful nor ormanental.

Orncir IV, - Meptandria, - Contains all flowers having seven stamens, the filaments being united in one set. This order contaius the beautiful and extensive genus pelargonium, or stork's bill, commonly known its geraniums. So numerous is this genns, that it his been 
divided by Botanists into thirteen sections, and many subsections; the whole including abore two hundied and thirty-eight species, und as many varieties and subrarieties. This genus occupies the whole order; there being, it seems, no other plant which can be ussociated with the pelargonium by similurity of flowers.

Ornar V. - Octandria. - Monadelphous flowers having cight stamens. This is, as yet, but a small order; Botanists having only met with two genera which suit the generic characters, namely, Aitonia and conesperma. The first a native of the Cupe, the last from New Holland, both green-house plants.

Onden VI. - Decandria.-Flowers having ten stumens united in one brotherhood. This order is composed of a great number of genera, some of which have many species. One of the most common is the genus geranium, which formerly contained both erodium and pelartrees, from every region of the known world: the bossion, crotalaria, aspulatus, geaista, cytisus, lupinus, tamarindus, dec, having mostly
papillionaceous flowers. On En VII.-Dodecandria.-Monadelphous
flowers laving twelve stamens. This order con-
tains twelve genera, all exotics, and mostly
from the warmer parts of the from the warmer parts of the globe. The heshrubs and trees: but the greatest ornament of 
the order is the astrapcea Wallichi, a native of Madagascat, which is a splendid flowering tree.

Orner VIII.-Polyandria.-Monadelphous flowers haring many stamens. This orler comprises many very fine flowering herbs, shrubs, and trees. Malva, althea, lavitera, paronia, and hibiscus, are all highly ornamental ; and only surpassed by the carolinea, adansonia, bombax, thea, and especially by the camellia, Barringtonia, and Gustavia. Many of these genera adorn our gardens; and the others om green-houses and stoves. For figure of field mallow (Malva sylvestris) see $\mathrm{Pl} .17$; $a$, pistil and ovary, showing the styles and some of the stamens attached.

\section{CLASS XVIF.-DIADELPHIA.}

Bisexnal flowers, furnished with two sets or brotherhoods of united stamens. The clarracters of this class are as follow:-Calyx, a proper perianthium, monophyllous, fire-dentate, the lowest tooth longest, supporting the carina, gibbous and deciduous; Corolla, butterfly-sliaped, mostly of five petals, sometimes four petaled:-the upper part is the vexillum, or standard, the two side petals are the alce, or wings, and the lowest is the carina, or keel; Stamens, the filaments united in two brotherhoods, usually mine united in one brotherhood, and the upper filament solitary, all inclined up- 
wards, and ench supporting a single anther; Pistillum, germen one, compressed, straight, as long is the united part of the stamens; Style one, filiform, inclined upwards, of the length of the separated part of the stumens; Stigma simple, downy, nearly as long as the style, deciduous; l'ericarpinom, a legumen, or its modification, a lomentum; Seeds round, or kidneyshaped, attuched to the upper suture of the pod by н11 umbilicus. The order's of this class are four, namely,

OnDER I.-Pentandria.-Diadelphous flowers haring fire stamens. This orler is constituted by one genus only, monnieria trifolia, a simall South American annual, descrilied by
Aublet.

Order II.-Diadelphous flowers having six stumens. This is a small orler containing only six genern, all of which ure herbaceous. Corydales and fumaria are two of the principal: three species of the latter, and three of the former genern are British plants. Onner III. - Octandria. - Diadelphous
flowers having eight stamens. This order contains four genera, the chief and best known of which is the polygali, or milk-wort. Of which genus the generic character is-Calyx of five unequal sepals, two of them winged and per. sisting; Petals from three to five, joined to the tube of the stamens, rexillum above, the keel crested; Stamens united in two sets, anthers 
one-celled; Style thickened at top, incurved; Stigma tubular; Capsula, inversely lieart. shaped, two-celled, two-seeded. To assist the student, we give a fignre of the common milkwort (Polygala vulgaris), Pl. 18; a, nflower magnified; $b$, the beard, or crest, laid open to show the stamens; $c$, ovary and style, ( 1 and 2 , the stigma).

There is only one species of polygala indigenous in Britain, and which has either blue or white flowers, and is frequently found on dry clialky banks. Some of the slirubby species from the Cape of Good Hope are very handsome.

Order IV. - Decandria. - Diadelphous flowers having ten stamens: that is nine in one brotherhood, and the tenth solitary. This is one of the largest orders in the Linnaan system; embracing all those plants, whose flowers are papilionaceous, or butterfly-shaped.

Here we find the useful pea, bean, trefoil, and many others bearing similar flowers. Some of the most magnificent flowering trees are also here, as the robinia, sutherlandia, aschynomena, wistaria, erythrina, dalbergia, dc. Nor is their beauty the only recommendations ; many are alimentary, or medical, or economical.

\section{CLASS XVIII, POLYADELPHIA.}

Bisexual flowers furnished with more tlian two sets of united stamens. 'This class contains two orders, namely, 


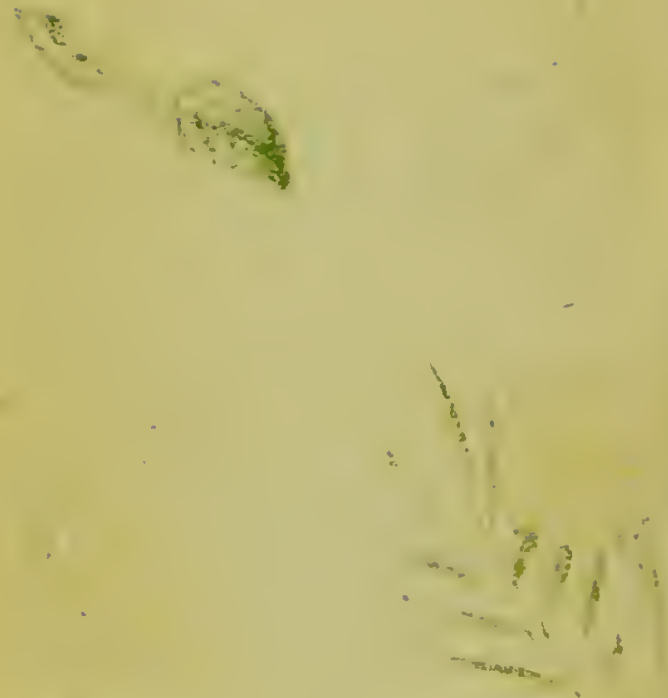

tas 

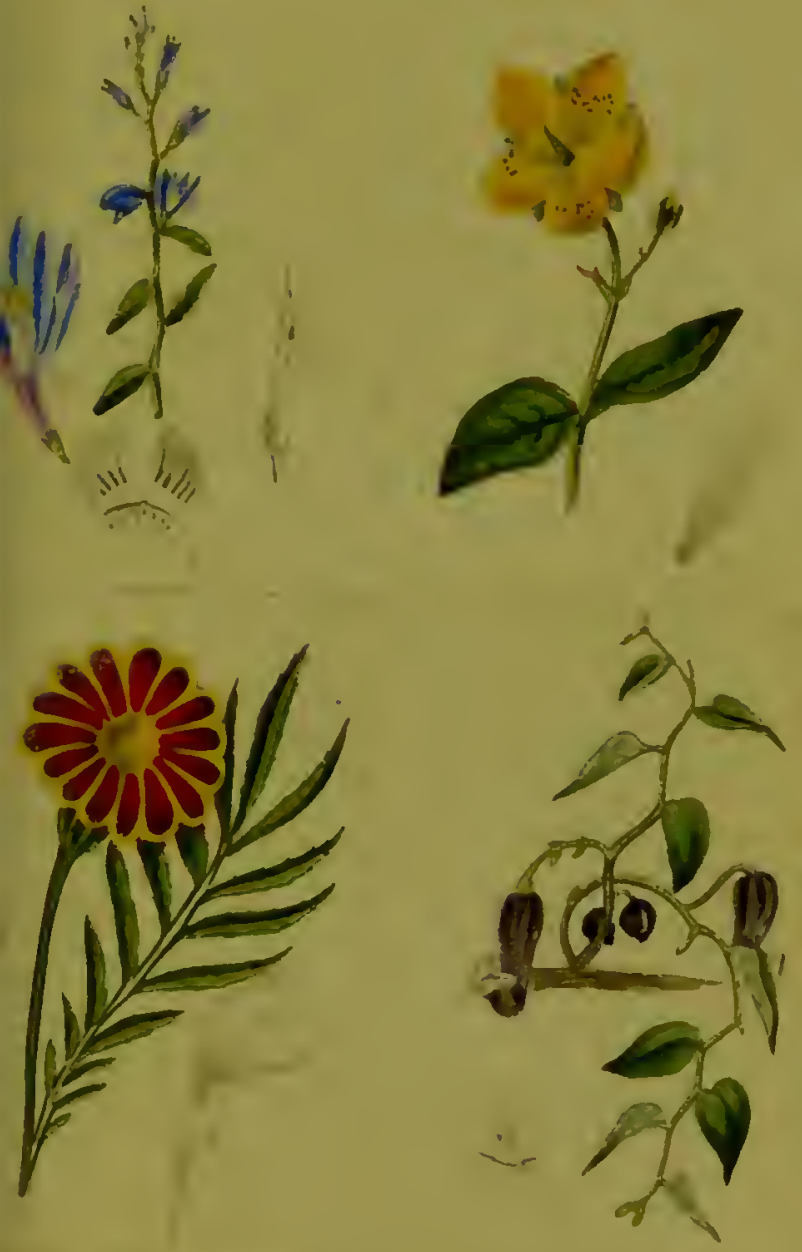

Ornen 1.-Decandria. - This order comprises all polydelphous flowers having ten stamens. There are only four genera described of which theobroma and abroma are chief. The first yield the fitnous chocolate-nut, which is manufactured into a fuvourite article of dict. Order I1.-Polyandria. - Hower's having many stamens, arringed in many brotherhoods. A principil purt of the genera of this older are New Ilollind plauls; such ure melilleuca, tristania, calothammuses, and beanfortin. But the most important genus is the citrus, prodnctive of the most ornamental trees, and a variety
of the finest samative fruits. But the inost filmiliar genus is the St. John's wort (hypericum), nine species of which are natives of Britain. To give an iden of the greneric claracters, we add that the Caly.x is in five pirts, and persisting, that is, it renuins entire after the petils and stamens live faded; Petals five; Stamens not in distinct bundles, nor any glands at the bise; Styles from three to five; Capsula of five ralves, ralves bent inwards: plapenta of each cell united at the centie; Seeds small and numerons. - Sprengel.

It $\mathrm{Pl} .19$, we hate figured a flower of the Intsin (androsamum officinale, formerly, hypericum androsamum); $a$, a bundle of stamens, us they separate, collering at the bise. The androsamum difters from hypericum in having three styles and a one-celled capsula; though 
both genera are in the same natural order. It is necessary to explain that, though the stamens do not appear to grow in bundles, they are shed in tufts as represented.

\section{CLASS XIX.-SYNGENESIA.}

Composite flowers. This class contains a natural order of plants distinct from all others in the regetable kingdom: hence also the mode of their arrangement in the Linnacan system is peculiar. The number of the stamens and pistils are useless here, as the same number is found in all the genera. Other characters are therefore had recourse to, on which to found the basis of subdivision.

The polygamy or intermixture of the sexes in the florets has been chosen for this purpose; which, althougl it may not be readily understood by a learner at first view, a little acquaintance with the diflerent orders will soon derelop the Limman plan of arrangement.

The term syngenesia signifies to generate together: hence the mnion of the anthers, which are attached side to side, and form a cylinder round the style, is the character which justities the title, and at the same time is the essential character of the class. 'The flower being composite, that is, formed of many florets, some of the parts must necessarily be common. These parts are the calyx or involucrum, now called anthodium, and the receptacle. These two or- 
gans are common, because the latter has all the florets seuted upon it, and the former includes them in its embrace, acting as n defence before flowering, and afterward as a protection in the seeds. The anthodium is generally imbricated and sometimes armed with prickles; when the corollets of the florets are fallen, it converges inwards and incloses the seeds, and opens again to perinit their escape.

'The common disk or receptncle of the flower, as alrendy stated, supports all the florets on its surfilce, which is either concave, plane, rounded, or conicul; and is either sinooth, except small cavities where the bases of the seeds are inserted, or paleaceons, that is, eet with chally scales which separnte the florets, or it is vil-
lose.

The florets are either male or female, bisexual or nenter, and admit of a great rariety of character. 'The character of a bisexunl floret may be thus described - Calyx, if present, is a small superior perianthium, persisting, and becoming the crown of the seed; Corollet, snperinr, if tubulose, the limb bell shaped, and divided into five segments, the segments revolute; if ligulate, that is, if the corollet, insterd of being tubular, is narrowed into a tongue, or strup-shaped expansion, it is always stretched divergingly ; Stamens tive in number, like hairs, inserted into the tube of the floret, anthers
five, erect, united by their margins, surrounding 
the style in all the bisexual florets; Pistillum inferior, being a naked seed, crowned with the other parts of the floret; Style filiform, erect; Sligma, of two parts, each part revolute, and divergent; seed a single one, at the base of the bisexual or female floret, naked as in the sunflower, crowned wilh the perianthinm, as in aster, or with a pappus, as in groundsel. This class is divided into five orders, namely,

Order I.-A Equalis. - This order consists of composite flowers having all the florets bisexnal, each being perfect. A vast number of genera are ranked here, and many of them have numerous species. We can only inention a few of the most common, in order that the student may hare recourse to the flowers themselies, to prove and profit by the descriptions: namely, dandelion, sowthistle, and lettuce; these have all ligulate florets. Carduas, cynara, and cnicus hare globose flowers; the artichoke (Cynara Scolymus) is a good example of the cliss and order.

Onder 1I.-Superflua.- Flowers belonging to this order hare the florets of the disk bisexual, and those of the radicus female : these list however heing impregnated by the pollen form the disk. 'There are many" fine flowering plants in this section; the gnaphaliums, metitlasias, elichrysums, \&c., are all universally admired, and so are the asters, cinerarias, and duhlias : of the varieties of which there is now 
no end. The chrysanthemums are also great favourites. Pl. 20 represents a flower of the French marigold (Tageles patula); $a$, a floret of the lisk; $b$, a floret of the ray; 1 , the seeds.

Ondar III.-Frustranea. - Inelfectual polygamy; the florets of disk bisexual, and of the radius or margin neuter. This order contains many well known plants; for instance, the sunflower, rudbeckia, coreopsis, calliopsis, the large genus centaurea, drc.

OndEn IV. - Necessaria.-In this order the florets of the disk are male, and those of the margin female; this circumstance giving the title to the order; calendula, arctotis, osteospermum, and othonna, are the principal genera, some of the species of which bear splendid
flowers.

OnnER V.-Segregata. - Separate polygamy; that is, the florets in which the character of the cliss is exhibited, have either eatch its proper calyx besides the anthodium : or they are contained, severul together, in a proper calyx, or calyculus as it is called by Botanists. This order includes abont thirteen genera, all exotic plants, the elephant's foot, and the globe thistle, being two ol the principal genern.

\section{CLASS XX.—GYNANDRI.}

The Linnæan character of this remarkable class is, that both the male and female parts 
are seated together on the pistillum or central column of the flower. It contains three orders, namely,

Order I.-Monandria.-Gynandrous flowers having one antler. A great many very curious, as well as beautiful, tuberous perennial herbs are ringed in this orler. Nearly forty species are indigenous in Britain, and constitute a tribe of the most interesting objects in our meadows and woods. The platanthera, gymnadenia, orchis, ophrys, neottia, dzc., are among those which are British, and miny rery splendid Howering species are the produce of foreign countries.

Oriner II.-Diandria.-Gynandrous flowers having two anthers attached to the column. This order comprises only two genera, namely, the stylidium from New-Holland, and the cypripedium, one species of which is the most remarkable of British plants, and admired by every one for its elegant slipper-like form.

ORner III.-Hexandria.-Gynandrousflowers having six anthers growing on the pistillum. This order contains but one genus, but that a very curious one, mamely, the aristolochia or bijthwort. The generic character is:-Caly.x corolla-like, swollen at the base, limb varied; Corolla none; Anthers two-celled, cut-in, at the sides of the stigma; Capsule below, sixcelled, many-seeded; Seeds compressed, scaled, and often winged. We give a figure of the 
snake-root (Aristolochia serpentaria), Pl. 21 ; a, a section of the flower showing the colunu and stumens.

\section{CIASS XXI.-MONECIA.}

This class contains all plants having male and female flowers separate on the same root; not connected with the same calyx, as in the eighteen first classes, or within the same anthodium, as in the nineteenth, or within the same sepals, as in the twentieth; but quite upart on different stations of the plant. The orders in this class are ten, namely,

Orner 1.-Monandria.-This order contnins five genera, the male flowers of which have only one anther. 'The most interesting genus is the artocarpus, the famous bread fruit of travellers. One plant is only found belonging to this order in Britain, and that is the pond. weed (Zannichellia palustris). The other genera are foreign.

Onder 11.-Diandria. - Monocious flowers, the males having two stamens. This order contuins four genera, one of which is a well known British nquatic plant-the duck-weed (Lemna), so commonly seen flouting on stagnant pools, and of which there are four species. The other genera are foreign.

Orner III.-Triandria.-Monccious flowers, the males having three stamens. The comptonia and hernandia are two of the prin- 
cipal genera in the order; but that which have the greatest number of species are the bur reed (Sparganium), and carex, both aquatics, chiefly British. The latter is divided into thirteen sections, but are all uncultivated worthless plants.

Order IV, - Tetrandria, - Associates all moncecious flowers, of which the males have four stameus. Here are some useful timber trees, as the box, birch, and alder; two fruits, the mulberry, and osage orange ; several shrubs, among which is the aucuba, and among many weeds the odious nettle.

Order V. - Pentandria. - Contains all monœcious flowers, the males having five stamens. 'This order consists chiefly' of annual plants; among others, the showy amaranthus is universally cultivated as a flower garden annual. Some Botanists place the amaranthus in the fifth class, and describe the flower as follows:- Floneers monœcious; Caly.r, of from three to five sepals; Stamens, three or five, distinct; Styles, deeply divided into two or three parts, seed-ressel a utriculus cut round, one seeded; Seeds covered with an arillas. We add a figure of the flower of love-lies-bleeding (Amarantus caullatus), Pl. 22; a, a flower having a pistil; $b$, a flower having stamens, botly surrounded by bracts inclosed in a calyx.

Order VI.-Hexandria.-Includes all mo. nocious thowers, the males having six staniens. 

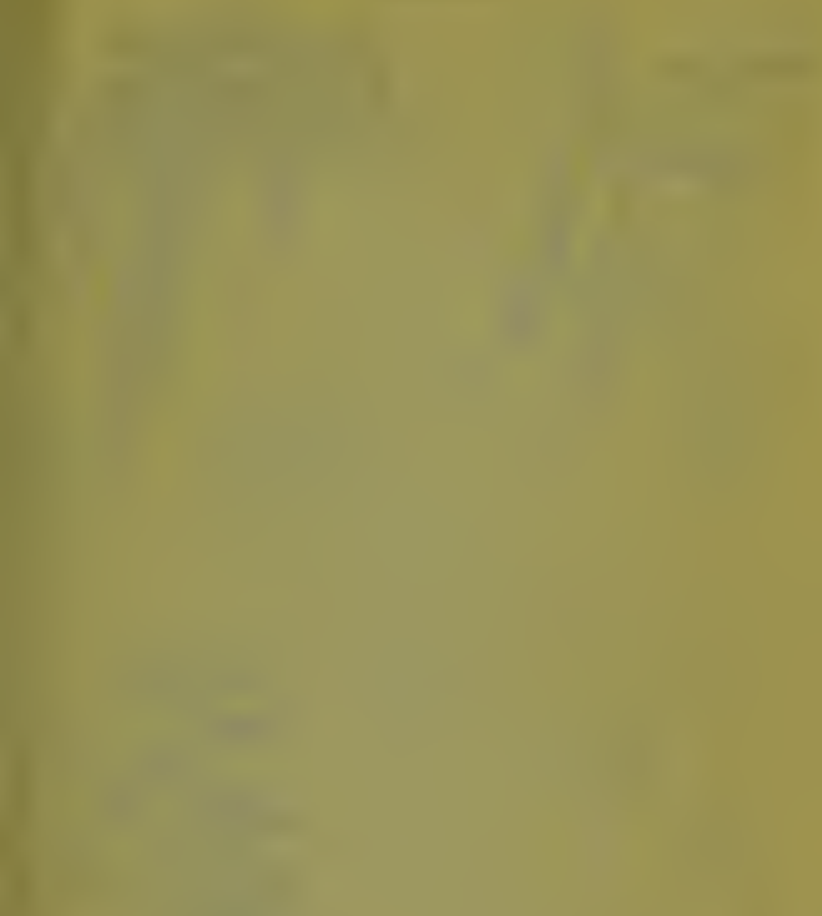

tra
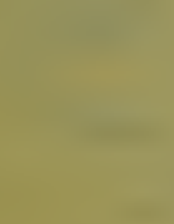


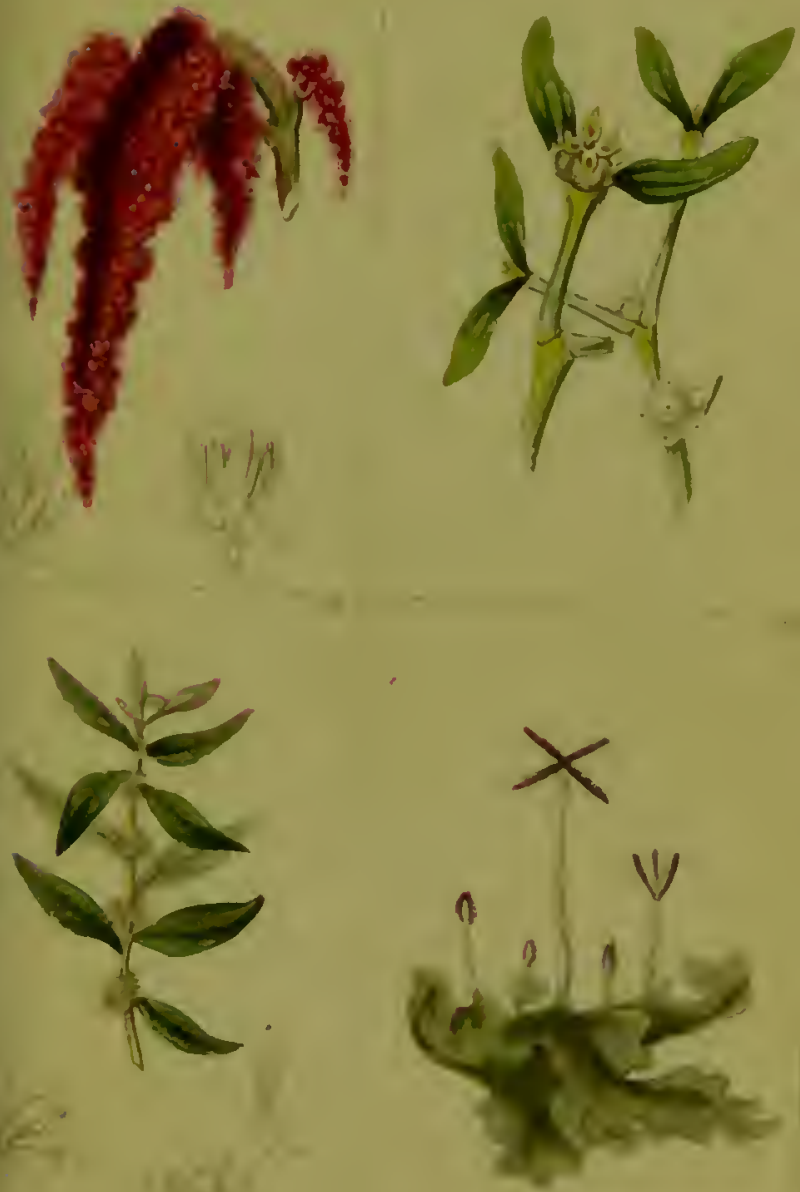

Except two genera, which are grasses, and one fine genus of trees, numely; the guettarda, all the remainder ane palms, including sagus, cocos, elate, bactris, acrocomia, dec. These palms hare been placed here since the time of Linnacus.

Onnen VII.-Octandria.-Moncecious flowers, the males having eight stamens. This order has only one genus, duvinu, of which two spe. cies have been described under the name of schinus.

Unmer VIII. - Ieosanilria. - Monacious flowers having more than tuenty stamens inserted into the caly.x. This order contains but one genus, the atherosperma moschata, a New IIollind tree introduced in 1824 .

Ounrar IX. - Polyandria. - Including all plants with moncecious flowers, the males having many stimens seated on the receptacle. This is an important order, as containing a great portion of our most useful timber trees; such as the hornbeam, beech, walnut, oak, plane, and four or five palms; together with a good many curious herbaceons plants.

Orpin X. - Monadelphia. - Monœcious flowers, the males being united in one brotherlood. This is also an important order, as containing the numerous genus pinus, with its natural allies, the cedars, cypresses, arbor vitix, frc. II ere are also the fruits-bearing herbs, cucumber, melon, gourd, dec., and many curious 
shrubs, as the phyllanthus, xylophylla, dec. The begonia is a good type of this order.

\section{CLASS XXII.-DICECIA.}

This class contains all plants that are unisexual; that is, the male flowers being on one plant, and the females on another. Conse. quently, both are barren, unless the inale and female plants grow near together. The class is livided into thirteen orders.

OrDER I.-Monandria.-Diœcious flowers the males having one stamen. This order contains only two genera, namely, the pandanus or screw pine, and the triclocladus, an $\Lambda$ frican shrub. The former is remarkable for tha regular screw-like position of its long sword-shaped leaves, and appearing like an enormous pine-apple plant on a lofty stem.

Order II.-Diandria.-Dicecious flowers, those on the male plants having two stamens. This order contains only four genera; one of which is the extensive genus salix, the willow, a great majority of which are British natives; the species showing every grade of lofty trees, shruls, ind dwarfs resembling herbs, indeed one species is called salix herbacea.

Order III.-Triandria.-Diœcions plants, the male individuals bearing flowers having three stamens. The principal genus in this order is the date-palm (Phonix dactylifera), a highly useful fruit tree, indigcnous to northern 
Africa, Syria, and Persia, where the fruit is a necessary of life, and an important article of commcrce. The only British plant in this order is the crow-berry (Empetrum nigrum), a small shrub, found on moist heaths in the north.

Onner IV.-Tetrandria.-In this order the male plants bear flowers having four stumens. The most extensive genus in this order is the leucadendron or white-tree, a native of the Cape of Good Hope, of which there are nearly. forty species. The sweet gale (myrica), or candleberry myrtle, n native of Britain, also belongs here. But the most familiar type of this order is the remarkable mistletoe (I iscum album), of which we have given a figure, $P l .23$. The flowers are described thus:Calyx, scaicely visible; Corolla, of four pctals; Anthers, ncarly sitting, and pressed to the petals; Stigma, sitting and roundish ; Fruit, a berry of one secd, which one has of ten several embryos.

Onner V.-Pentandria.-Male plants havnut (Pistacea officinarum), is one of the most conspicuous genera of this order, and which produces nuts useful for various purposes. Here is also the toothache tree of Jituaica Indies, the bark of which is used for making ropes. Also our common culinary spinach, aud 
as common hop ind hemp. The inule plunts of these last three are easily detected annong the females, when seen growing together; ind it may be satisfiactory to the student to attend to this circumstance when an opportunity offers.

Order VI.-Hexandria.-Male plants producing flowers having six stamens. Here are xerotes a herbaceous genus fron $\mathrm{New}$ Hol. land; six different sorts of palms, the climbing smilix, and tamus (or black brjony, common in English hedges), and the dioscorea or yam, so useful in India.

Orden VII.-Octandria.-Male plants furnished with flowers or cutkins, having eight stanens. This order contains only one genus of hardy trces, namely, the poplar. Of this, there are twenty-four species, four of which are natives of Britain, and abound on the banks of rivers or pouls.

Order VIII. - Enneandria. - In this order, the male plants bear flowers having nine stamens. It contuins only three genera-mercurealis, triplaris, and hydrocharis. Two species of the first, and the last, the flog-bit, are natives of this country in hedges and ditches.

Order IX.-Decandria.-Male plants having flowers with ten stamens. This is also a small order, comprising only five genera, all exotics. The gumnocladus is a lurdy deci. duous tree, introduced into this country in 
1748, and belongs to the natural order leguimnosa. The carica or papaw is an East Indian fruit, likc a melon, but much inferior.

Onder X. - Dodecandria. - Male plants having flowers furnished with twelve stamens. This order is constituted of six genera, all herbs and shrubs. The moon-seed, menisper. mum, a clinibing shrub, is one of the principal genera; one only is British, the witer-soldier (Stratiotes aloides), an aquatic plant.

Order XI.-Icosandria.-Male plants bearing flowers hasing abore twenty staniens seated on the calyx. This order contrins three genera, all tropical plants, and of no particular interest.

OrDER XII.-In this order, the male flowers have many staniens sented on the receptacle. Here the two curious genera of cy. cas and zamia, dwarf palm-luoking plants are placed, together with flacourtia, an important tropical fruit-bearing genus of shrubs and trees, and the cliflortia, a Cape family of evergreen shrubs, frequent in our greenhouse collections.

ORDER XIII. - Monadelphia. - Diacious plants, the male flowers of which have their stamens connected in one brotherhood. This last order of the class Diøcia contains some majestic genera, as the arauciria and altingia, belonging to the abietinia section of the conidred to one hundred and fifty feet; there is also the latania, a fine palm, the juniper, yew, the

$$
\text { o } 2
$$


valuable nutmeg, and the curious nepenthes, dec.

\section{CLASS XXIII.-POLYGAMIA.}

The title of this class signifies many marriages; indicating that there are unisexual, or bisexual, flowers on the same, or on diflerent roots. The class is divided into two orders, namely,

Order I. - Moncecia. - Contains plants, which have unisexual and bisexual flowers on the same plant. This order comprises many estimable plants; such are the mimosa, acacia, with its numerous species; the useful cereal sorghum, the maple, celtis, ailantus, clusia, and that excellent fruit, the mango, besides several palms and grassses.

We figure on $P$. 24, the wall pellitory ( $P a$ rietaria officionalis); $a$, a fertile flower; $b$, the calyx of a sterile flower; $c$, perfect flower laid open. The generic character of this genus is: Flowers involucrated; Involucrum more or less divided. Bisexual flowers; Calyx fourcleft ; Corolla, none; Stamens, four filaments, elastic; Anthers, two-celled; Germen crowned by a bearded stigma. Male and female flowers have a tubular four-toothed calyx; Style, rery simple; Stigma, bearded; Seed, included in the calyx.

Order II.-Diøcia.-Contains plants which have male, female, and male and fennale united 
on two distinct roots. It was supposed by Linnaus, that these mixed marriages existed on three separate roots; but this has not been confirmed by subsequent observation.

This order conprises the fan palm, gleditschia, the carib-tree, and date-plum, the ash, a timber tree, ancardium, a fruit, and the large genus ficus, of which the cultivated fig is the principal species.

\section{CLASS XXIV.-CRYPTOGAMIA.}

The meaning of this title is hidden marringes, by which the author only meant, that the plunts had no visible flowers. But, arguing by analogy, Linnæus concluded that all plants must have flowers, although they conld not be seen. He was cognizant, however, that the plants in this class were reproducible by atoms discharged from certain parts of themselves; but which he did not consider as perfect seeds,
but a kind of viviparous progeny, which are a suituble bed. These vital particles he called propayines, or, as they are now called, sporules, and whatever their real structure may be, they possess the sume principle as that of perfect
seed.

This class contuins nine orders, namely,

Onder I.-Filices.-Ferns are a very peculiar 
rally creeping underground stems, frequently branched; from the points of these, the foliar expansions are annually produced. These expaissions are called fronds, and bear the fructification on the back, either in dots along the margin or nerves, or in lines variously disposed. Sometimes the fructification is borne on a loose and separate spike; and sometimes small spikes are appended to the apices of the divisions of the fronds. A few of the tropical species have a tree-like port, and vie in stature with some of the palms, to which, except in their fructification, they are nearly allied. This order is divided into five tribes, namely, polypodiacea, osmundaceæ, gleichenicæ, poropterides, and aphioglossea, merely for facilitating the study of this, to some Botanists, most interesting genus of plants.

The general arrangement of the ferns is according to the modifications of the spots or lines of the fructification, and the absence, presence, and manner of opening of the conceptacles.

Orner II.-Equisetacea.-This order con. tains one genus only, of which there are ten species; of these, seren are natives of England, where they are culled horse-tail, or frog-pipes. They are inostly found growing in pools, or on damp clayey ground, and are of a regular pyramidal figure; stems jointed with whirls of 
linear leares at each joint; the fructification forming a spike on the summit of the stem.

Orner III.-Lycopoducea, - Contrins only two genera, namely, lycopodium, the club-moss, and psilotum; of the latter, there is only one species yet described; and eighteen of the former, of which six are found in Britain, usually in boggy pools.

Onner IV.-Marsileacec.-This order contains four genern, namely, isoetes, quillwort, pilularia, pillwort, salvinia, and marsilen. 'The two first are British. The quillwort is an aquatic; but both are small inconspicuous plints, with fructification near the root.

Order V.-Musci. - The mosses ire numerous, and differ in bulk from mere atoms to branched plants two teet in length. The fructification of the mosses is inuch more distinctly visible than some other orders in this class. Dillenius detected both male and female flowers; the anthers corered with a calyptra, or veil, and under this another corering called by Linnaus an aperculum. The seeds are Onder VI.-Hepatica. - This order contains six generi. The most extensive genus is jungermannia, of which there are a grent many species. The leaves are of various formssome entire, other's more or less divided. Some lave stipules, others none; but all growing in loose or dense tufts or patches, on walls, or 
bark of trees, on rocks or on bogs; many aflect moist places, and a few are floaters. $P l$. 25 is a figure of .Jungermannia (J. Pinguis).

Onnen VI1.-Alga.-This is a very large order of cryptogamic plants, comprehending all the seit-weeds, and many others found in rivers, pools, and low damp places. Their forms are as rarious as the species; some are like minute spots, or tufts of silky hair; others foliacions, and have petioles or stems many feet in length.

Orner VIII.-Lichenes.-This is also a very lurge order, comprising thousands of small organised bodies, attached to the bark of both living and dead trees; on the bare earth, on stones, and rocks of different descriptions; in short, on the surface of every kind of stationary matter. Some of them are enten by animals, it few medicinal, and sereral are economical.

On DER IX.-Fungi.-Of all the cryptogamic orders this is certainly the most extensive, and it may be added, without exaggeration, that there are, perhalps, as many nondescripts as there are species alleady described; althongh these amount to nearly twelve hundred! Besicles the division called mushrooms (agaricus), there are many unheeded genera, which are produced on live and dead regetables, and particularly on animal and regetable substances which are in a state of decay. Fruits and grain, and the young shoots of living trees, are the 
prey of fungi, and some of them have even the power of decomposing the hardest timber.

To these twenty-four clusses, Linnæus added an appendix, in which he included all the palms that were then known-ten in number; but since his time, these remarkable plants have been described, and transferred to the class and orders to which they respectively belong in his sy'stem.

In tuking a retrospective view of the Sexual System of Linnæus, it appears to be one of the best defined artificial methods that ever was invented; not only because it is consistently derired from one simple principle, but also becinuse the anthor of it, by means of new nomenclature, hus given to his terms the greatest distinctness of meaning. Hence the student with but a small degree of attention, and a very little libour, can soon comprehend the princi-
ple, and acquire the terms. When this is ac-
complished, he finds complished, he finds little or no difficulty in referring erery flower that falls in his way to its proper class and order; especially those belonging to any of the first eighteen classes. The remaining classes certininly' require inore study, but a litlle persererunce, and by frequently comparing the characters of the classes 
and orders with the flowers themselves, a facility of classification will soon be gained: and this to the young Botanist will be a constunt source of pleasure, and innocent anusement.

Every newly blown flower of the season, and every strange blossom which accident presents to notice, is an inviting and fresh subject for examination and mental exercise; and when the cluss and order is ascertained, and the proper name discorered by this easy process of investigation, the result is always exceedingly gratifying to the juvenile Botanist. Every successful step, and every new acquisition made in this way is an advance towards gaining such a competent knowledge of the science, as will be for ever afterwards a constant source of unalloyed delight and satisfaction.

While thus engaged in the pursuit of a kuowlcdge of Linnæan Botany, years of pleasinrable exercise and rational amusement may roll away before the student will discorer that the system is only an artificial dictionary of the names of plants, in which he may neither find nor suspect any thing like incongruous associations; but that it is not free from incongruities is perfectly obvious, and many were detected, even during the lifetime of Linnæus himself, who well knew its defects, and whose candour admitted, and whose penetration foresaw, that there was yet unother system in the womb of futurity, and within the bounds of precticability, that would 
be inore consonant with nature, and a more valuable acquisition to human knowledge.

Linnieus bequeathed to his posterity "frngmeuts," of a natural system ; and this circumstance is a complete exculpntion of the temerity of his successors who have set isicle nearly the whole of his celebrated sexual system. They have only done what he hinself would have done had his life been prolonged. On the broad principle of consistent philosophy, systenatists ure bound to udhere as closely as possible to the grand features of aflinity and verisimilitude whicl nature lierself has so visibly marked. And, according to this principle, the late eminent Botanist, Jussieu, has founded what is now called the N.iturit Srstem.

That celebrated Botanist, possessing a most extensive knowledge of plunts, has, with immense labour und study, drawn out the grand outlines of a system which is likely in time to supersede all others. Its details he left imperfect; but his followers are every diy making iniprovements and alterations, with a view of perfecting what Jussieu so worthily began. 'The outlines and principul characteristics of his system alre chosen with great judgment, becaluse they ure naturally invariable; but the detiils curried out according to the rules he has laid down, extend and are extending to a frightful length. Some of the orders are founded on such trifling differences 
of structure, that there appears to be no boundary or limit to the orders, so long as botanical research is prosecuted with glasses of high magnifying powers only.

So much is this diffusiveness of the natural system complained of by practical, as well as by literary Botanists, that it is a "consummition devoutly to be wished," that some influential MASTER, or band of masters, would undertake the task of circumscribing the natural system; and invent some scheme of amalgamating the scattered orders into manageable groups, so that the system might be more inviting to the student than it is at present.

In proceeding to give the necessary details of the Jussieuan system for the information of the young Botanist, we shall endeavour to make the path along which we propose to lead our pupil as smooth and agreeable as possible; becanse as the approaches to a science, whatever that science may be, are usually rendered rugged by its terminology, care must be taken that the progress of the tyro be not impeded by the unnecessary use of hard or learned terms.

It has been made a question in describing or teaching the science of Botany, whether the pupil should commence his studies at the highest or lowest grade of regetation. In other matters of human concern, whether of mental improvement, or manual dexterity, the 
elementury parts ure ulways first presented to the attention. But it is said, that in the case of Botany the reverse should be alopted; inerely for this reason, that the lowcst grade of vegetubles arc microscopic objects, and consequently make less impression on the mind than such as are pulpable and visible, and of course ensicr demonstrable. To the demonstrutor, it is certuinly much more agreeable and much more easy ulso, to illustrate his lecturc by pointing to the different parts of a plant on his table, than by attempting to show the parts of a fungus devouring the point of a peach-tree shoot. Notwithstanding this, we think that rising from small to greater, from the lowest to the highest, is a morc nitural way of proceeding than the reverse; and therefore in the succeeding pages we shall proceed on this principle. 
206

TH $\boldsymbol{H}$

\section{NATURAL SYSTEII OF BOTANY.}

Ir appears that the autlior of this system, possessiug, as he did, a thorough knowledge of all that had been written and discovered before his owin time, was enabled to take a comprehensive view of the vegetable kingdom, and of all that had been published concerning it. While on the one hand he saw the defects of all previous systems, he could not be ignorant that the attempts of Tournefort had been so far successful as to have brought together, unintentionally or accidentally, perhaps, several of the truly. natural orders.

He was also acquainted with the sentiments of the great Linnaus on the subject of natural classification; and, availing himself of the hints bequeathed by that enlightened natural 
philosopher, he became impressed with the idea that the arrangeinent of a natural system was fairly within the bounds of practicability.

In the pursuit of this grund object, Jussieu found it necessary, in the first place, to divest himself entirely of all previous schemes of classification, and have recourse to other distinctions among plants than those which had been before employed in systematic Botany. He naturally turned to the physical components and structure of regetubles, where he soon found distinctions which were perunanent, invariable, and at the same time easily discernible. These were the cellular and vascular apparatus of plants, already described in the former sections of this work.

These distinctions, so evident and truly natural, served at once to divide regetation into two plain and easily definable parts. This was the first, and a most important step; and the second step or discovery was not less so. IIe also found that the cellulur plants were not only distinguishable by their internal structure, but also by the remarkible circumstance that their sporules or seeds gerıninated without the usual appendages of cotyledons, or seed-leaves. Thus the first or lowest division of plants he culled cellulares, because composed entirely of cellular tissue, or acotyledones, because the
plants are destitute of seed leaves, or cotyledons; these together constituting one grand 
division of the regetable kingdom, which he afterward subdivided, as will be shown presently.

The other grand division he called vasculares, from their varied and more complex physical structure, otherwise cotyledoses, from the circumstance of their seedlings germinating with the appendages of seed-leaves. On a further examination of this grand division, Jussieu found that it was divisible into two classes:certain plants rising with one cotyledon, and others with two; hence the first he called monocotyledones, and the second he termed dicotyledones. In this last, which comprehends by fur the greater number of the most useful and beautiful plauts, he found it necessary, for the more easy arrangement of the numerous genera and species, to have recourse to certain parts of the flowers which were the least variable, to typify other divisions, which he called subdivisions, two in number, and which are again separated into sub classes.

A scheme of the natural system may be sketched thus:

There are two grand divisions: - first, the Celuulares, which contains two classes, Aphylla and Foliacea:- and, secondly, the Vasculares, which also contains two classes, Monocotyledoner and Dicotyledonere.

The two classes of Cellulares are again subdivided into orders containing one or more 
genera, having tilles derived from the names of some one of the genera that is typical of the order.

The second class of the Vasculares is divided into Monochlamydece and Dichlamydece. The subdivision Dichlamydex, is again divided into three sub-classes. The second grand division comprises every kind of flowering plant, all bearing the general title of phanero-
gamia.

The first class monocotyledonex, the subdivisions monochlamydex and dichlamydex, are also divided into genera on the same principle as those of the grand division Cellulares.

These particulars will be more fully explained in the succeeding review of this ingenious system, when we shall study to make the whole as plain as possible.

Returning then, to begin with the lowest order of plants, we cannot resist quoting from a late writer what he has offered as an apology for extreme plainness in botanical dissertations. "Much of the arrangement," says lie, "seems very naturnl, and most of the terms names be as carefully defined as those of Gireek and Latin? for although not all so classically is, they are equally intelligible, and far more euphonous, than many semi-barbarous techni- 
that they are generally known, as we merely propose to use the most familiar terms; because, although many persons are well versed in botanical language, to many it may be otherwise and obscure. Who is there who has not, at some time, felt the galling yoke of technicalities? Who is there that has not found, that to learn a science, and at the same time to be obliged to learn a language, is indeed to have the tale of bricks demanded, while the straw to make them is denied. We shall, therefore, in order to lessen this evil, in conjunction with the scientific names employ the common English synonymes, whenever such exist."-Bur.

\section{ACOTYLEDONES.}

\section{CLASS I.-APHYLLZE.}

\section{FUNGI.}

In descending to the lowest point of regetable life, we are stopped at that barrier beyond which our ocular powers cease to serre us. That many genera of the fungi are inconceivably minute, we are well aware of ; many indeed so small, as to be only known by their effects; their presence being indicated only by a discolouration of the hody or surface on which they grow. Individually they are invisible; but as they appear in legions they come into view. 
Such are the rust on corn, the moulds on stale hread or cheese, on cloth, or other matter. Indeed there is no kind of decinyed or decaying animal or vegetable substances but attract and become the prey of one species of fungus or other. On this account they have been well called and considered as the scavengers of nature; for no sooner does any animal or vegetable matter become useless or poisonous to unimals, than it bccomes a bait for the fungi, which devour and decompose the noxious matter, and thereby render it wholesoine food for the regetation of the following season.

But how, it has heen asked, are such myriads of fungi disseminated? The answer is, by the vapour-like and wandering habits of their sporules which float about in the atmosphere in countless numbers, only waiting for the presence of a fitting soil on which to alight und grow. It is supposed that fungi never
fix upon any substance which is healthy. That
some prc-existing disen some prc-existing disease or disorganisation must invite the attack; and it is a most wonderful provision of nature, that the vast hosts of fungi do not appear till that period of the year, when regetation is on the wane, shedding its many of the insect tribes have danced away their fleeting life in the solm beams, lie down to die on the cold and humid earth, that the fungi cone forth to seize and clear away those 
noxious exuvia of recent life, lest accumulated corruption should taint the vital air, or render sterile the fruitful bosom of the earth.

The peculiarity of their agency, says Lyell, consists in their power of suddenly multiplying their numbers, to a degree which could only be accomplished in a considerable lapse of time in any larger beings, and then as instantaneously relapsing, without the intervention of any violent disturbing cause, into their former insignificance. Our admiration is strongly excited when we contemplate the powers of insect and fungus life, in the creation of which nature as been so prodigal. A scanty number of minute individuals, only to be detected by careful research, and often not detectable at all, are ready in a few days or weeks to give birtlı to myriads, which may repress or remove the deleterious matter. But no sooner has the commission been executed, than the gigantic power becomes dormant; each of the mighty host soon reaches the term of its transient existence; and when the fitting food or offial lessens in quantity, then fewer of the spores find soil in which to germinate: and when the whole has been consumed, the legions before so active, all return to their dormant inactire state.

But it may be asked, how is it in the case of rubigo, the red rust, or blight on whent, to be accounted for? On one diny, the whole field 
looks healthy and promising, the straw of a bright golden glossy uppearance, und the eurs nearly filled; in a few days afterwards, the golden hue is changed to a dead white; instead of the bright gloss, ranks of black lines soil the surface and clange it to a dingy shade; the magnifying glass applied shows thousands of little inush rooms, ranged in lines or bursting out in tufts, checking and exhausting the current of the sap, and robbing the grain of half its bulk. What is it that invites the attack in this case? Practical experience has taught us to answer this question. The plants have received a sudden check from a night frost, or from a day or two's prevalence of clouded skies, and a humid stagnant atmosphere; the sitp is arrested in its ascent, becomes tainted or corrupt in quality, and consequently a favourite bed for the support and encouragement of the fungi. 'This is a case, however, in which we cimnot reconcile ourselves to contemplate with gratitude the general good performed by these minute plants; because in this, their interference is apparently a misfortune. But here, we must not mistake the effect for the cause. The corrupted sap might be at prejudicial to the gruin as its extraction by the Uredo.

This and other species of fungi are very. peculiar in their aspect and character. They are destitute of external organs; they have neither flowers nor leaves, nor any members 
which show the slightest resemblance to them, and even their stem, when present, is unlike the stem of other plants. In their colouring they are remarkable; nature, having withleld froin them those flowers which form the clief beauty of the higher orders of plants, and even the leaves with which they are clothed, has profusely scattered her colours orer the whole surface of the mushroom; ornamenting the cap with one colour, the gills with a second, and the stem with a third, and often blending in stripes, or shading two or three tints into each other, as in Agaricus psitlacinus. Many, indeed, of the fungi rival in symmetry and splendour the tulip and the lily.

But they are a degraded and neglected family of plants; for so long as they are only known by the names of blight, blasts, brands, rusts, moulds, puff-balls, toad's-stools, mildews, dec., no high opinion is entertained of them; and very few are interested in becoming acquainted with the products of corruption. Some of the moulds are even poisonous; and rery afflicting accounts are on record of whole families being poisoned by eating mouldy provisions. Here however, we should pause, and not attribute to the fungi what is really occasioned by the halfputrified and unwholesome state of the riands. The presence of the fungi sliould rather be esteemed as a providential sign of the deleterious quality of the body they grow un, to warn 
the consumer to be on his guard against its use.

One of these fingi, under the name of smut, destroys the nutritious flour of the whent and other grain; and when ground with the sound grain renders both flour and bread unpalatable and unwholesome. This is very different fron the rust which allects the straw; for this last only lessens the quantity, but hurts not the quality of the grain.

The sinaller species of fungi are so very numerous, that, it is not in our power to add their names, save as we have already done, under. their vulgar or provincial English names. But as the species increase in size, they become more faniliar, especially as some few of them are dietetic.

The mushroom (agaricus campestris), the morel (morchella esculenta), and the truflle (tuber cibarium), are universally known as articles of diet in one shupe or other. The first is extensively cultivated, and though there are many species of the mushroom which are eatable, they are all more or less dangerous, especially if produced on damp ground. Indeed, too much cantion cannot be taken in gathering mushrooms for use, us there are several unwholesome species which resemble the true one. The truflle and morel are only used in high cookery, and are not yet in cultiration in this country. 
We may mention one other fungus, which has some interest attached to it, in consequence of its value as a medicine. We mean the ergot of rye (Secale cornutum). This fungus takes possession of the grain, while in its milky state, and causes it to swell much beyond its usual size, in shape like a horn. The meal is changed to a grey powder, and remains within the unbroken husk. The ergot appears sometimes in this country, but it is very common in Spain, and in the south of France, where it is collected for the supply of European druggists. Where rye is employed as a bread.corn, the ergot is a dangerous ingredient: for when in excess, it is a fearful poison.

Three of the principal orders among the fungi are boletales, or mushrooms, the tuberales, or puff-balls, and the mucedinales, or mildews. Some of the puff-balls grow to the aunazing size of three feet in diameter. The mildews are frequent on the leaves of many plants, and on the points of the joung shoots of perch, and other fruit trees. Some of the mushrooms grow to a very large size, but they ure dangerous kinds. The external organs of the mush. room are the volva, or wrapper; the stipes, or stalk; the veil, which becomes an annulus round the stem; the hymenium, or gills, which contuin the asci, or spore cases, and the pileus, or cap. See $P l .26, f .2 ; a$, a section of the pileus. 


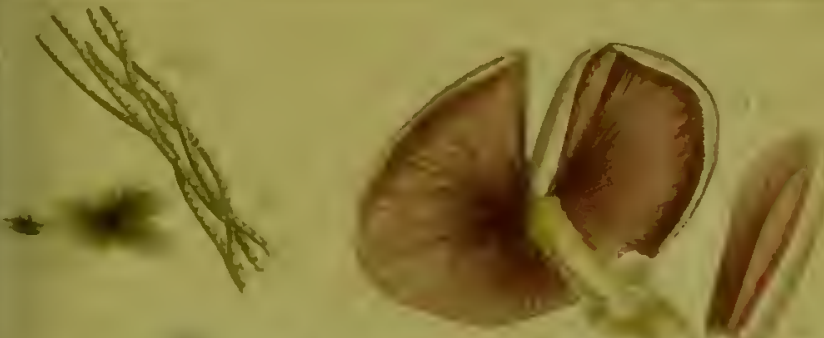

$\left.x^{2} \leq j\right)=1$
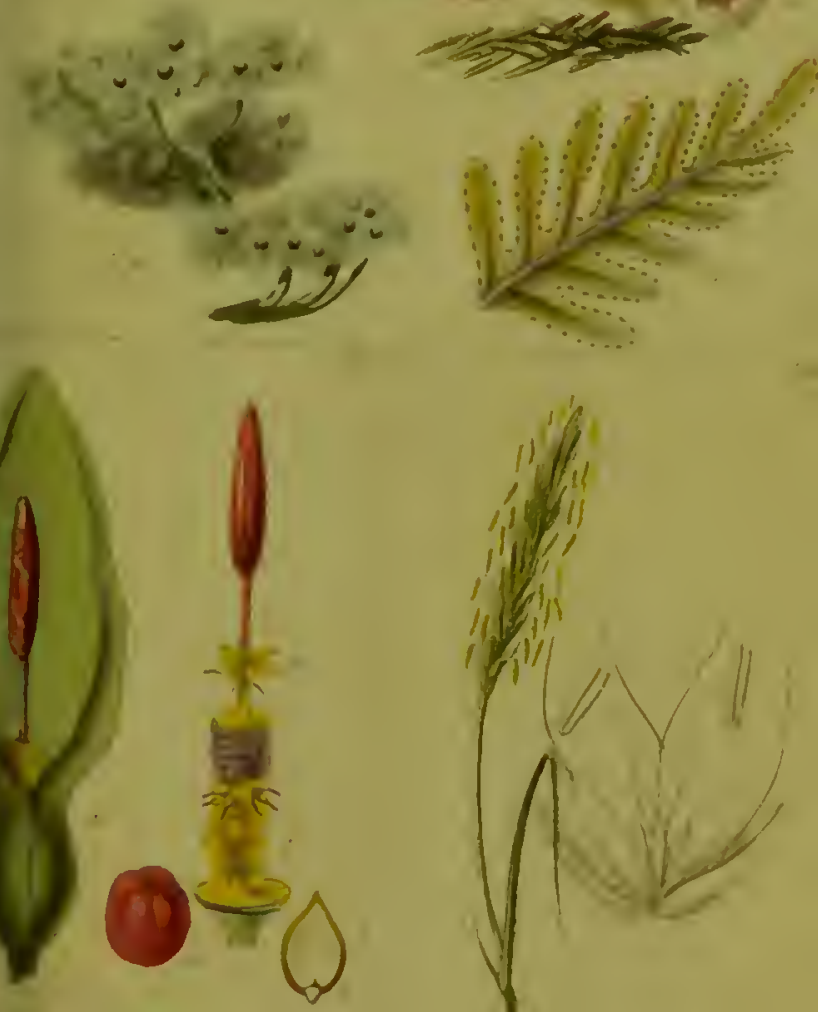



\section{ALGE AND LICHENES.}

The algae or fligs are many of them seaweeds, and hence their vulgar name, because, on the retiring of the tide, they flag down upon the rocks or sand on which they grow. On land, and especially on uncultivated ground, they clotlie the surface, climb up on rocks, and inhabit the trunks of old trees. They are usually shapeless masses of leather-like expunsions clinging close to the bodies on which they grow.

As a class, the flags are divided into orders, sections, and genera; and among these are found some of the most curious living structures which are as yet known. Here are protophytes, just emerging from lifelessness to life, and beings which, alnost animals, are yet most certainly real vegetables. Some of these flags are so simple and diminutive, that it is difficult to say whether or not they are flags or fungi; some of them, as the slimy matter seen on rocks and stones, on gravel walks, and on the glass of windows, however, diminutive, consist of curious and most admirable regetable structures. The green coating on trees and palings is composed of an infinite number of snall plants of an exceedingly curious
formation.

Among tlie lowly tlugs is the "red snow," 
often seen on northern mountains, and which is found to be a small plant, called "proto-coccus." 'This, as well as the gory dew (Palmalla cruenta), bloody rain (ÎTepraria kermasina), and many other sudden appearances on the earth, or in staynant water, are only aggregations of minute flags, which occasionally come into view, and as suddenly disappear. These are in the very lowest grade of this order, and, when magnified, appear only like an association of transparent globules.

The sea.weeds (fucales), the lavers (ulvina), and the kelpware (fucinc), are generally water plants. The lichens, on the contrary, are universally aerial, and found, as already observed, on rocks and trees. The history of the fuci, as yielding iodine and kelp, two such raluable articles in medicine and commerce, affords an instructive lesson to those persons who hastily and presumptuously condemn all things as useless, the use of which they know not; for that very weed confers great benefits on man; that flag, the gathering of which for years enriched both peer and peasant on our northern coasts, the very flag that now " affords the iodine, which really does relieve that evil which the boasted royal touch so long has fuiled to cure. "-Bur.

The decompositiou of the algie on the rocky surface forms in time a layer of mould, in which useful herbs, and ultimately stately trees, are raised to clothe the earth; many of the flags are medicinal, and one or two are fodder for 
the rein-deer. Of the alga we liave figured Oscillatoria urbica, $P l .26, f .1 ; a$, the natural size; $b$, powerfully magnified.

'The algo, lichms, and fungi form together the second class of Jussieu's second grand division of plants, namely, Cellulares, which he divides, as we have stated, into, first, foliacer, being lenfy, and secondly, aphyllce, leafless; both classes being entirely cellulur, and springing up from their spori or seeds, destitute of seed-leaves; hence they are also called acotyledonea. Of the Lichens we have given an illustrntion, $P l .26, f$. 3, the Eitster Stereocaulon ( $S$. paschale).

The leafless class we have already noticed in the preceding priges, and now proceed to remark on the six orders of the class foliacee.

\section{CLASS II.-FOLIACEZE.}

HEPATICA.

The hepatica are the first remore above the leafless cellulares, and are smull creeping plants; with leaves arraged like scales. 'They differ from lichens in structure, colour, and in fruit, and from mosses in the opening of their capsules. They are the connecting link between the flags and mosses. There are six genera and nearly one hundred species. The genus Jungermannia is one of the most extensive, one of which $J$. Pinguis, we have figured nt $\mathrm{Pl} .25$. 
These plants are mostly furnished with fructiferous thecu, sometimes imbedded in the frond, or raised on stalks, or pedicels. They are mostly obscure plants, growing in damp situa. tions, or on moist rucks or trees. None of them are poisonous; their taste is mild ; some few are fragl'ant, but not possessed of any very sensible qualities, nor have they been applied to any useful purpose economically. The marchantia, another genus, is more especially called liverworts; hence the signature physicians attributed wonderful curative powers to these plants, especially to the $M$. polymorpha; the lobulated fronds of which species, from it fancied resemblance to the liver, caused it to be esteemed as a specific in jaundice, and other hepatic complaints. Though neglected as a medicine in this country, it is still used in others; it appearing to possess considerable virtues. The riccia and targionia are two other curious genera belonging to this order.

\section{MUSCI OR MOSSES.}

This order contains thirty-seven genera, and above three hundred species. They are rery common lowly plants, mostly growing in the cold seatson, and in cold countries. They are easily distinguished from the liverworts, by the possession of an operculum, or lid, which corers 
the urn, or theca, in which are contained the seeds or sporules. The mosses are distributed into three sections, which are distinguished by the different manner of the dehiscence of the urns. The generic or essential character of the mosses is in having the bottom of the axis prolonged into a fibrous root; the ascending axis is called a surculus. The regular divisions of the surculus ure called branches, and the foliaceous appendages are the leaves. Under the leares there ure little expansions called stipnles. 'The urns or thecn, borne by these plants are closed by a lid, and covered by a reil, or calyptra. This last opens in different wilys by long or short clefts, or not opening, remains to be broken up by decomposition. One of the inost minute mosses is the genus phascum of which there are thirteen species described, and though small ure all very beautiful. The sphagnum is a rank growing genus, and with the hypnum triquetrum, are the kinds so much used for packing. Both this and the bryum are known by their deciduous operculum. Mattresses und brushes are made of the prepared stems of the polytrichum commune, and in Lapland this moss serves the inhabitants for both bed and bedding. They choose the starry hended plants; out of the tufts of which they cut either beds or bolsters, separating the moss in flakes from the earth, and of which whole beds and bolsters, and even coverlets, are 
made; these natural fabrics, being elastic, are most agreeable couches, and are perfectly free from every kind of vermin.

Among the mosses we find the curious genus chara. They are leafless plants, but have whirled branches, and are remarkable for the counter currents of their sap observable in their jointed stems, and which exhibit a constant circulation, not from the bottom to the top of the stem and back again, but only to and fro between the nodes or joints of the stems. The chara are also remarkable for their power of depositing upon themselves the carbonate of lime, with which they become completely incrusted; hence they are called stoneworts.

A reinarkable property of the mosses is their tenacity of life. They may be kept in a dry cabinet for scores of years, and if afterwards laid in a damp place, and moistened with water, they will quickly revive, and grow again as well as ever.

\section{MIARILEACEA.}

The marsileacex is another order belonging to the foliaceous cellulares, containing four genera, of which there are one species of each in British lists. The genus isoetes, or quillwort, is a native of Britain, and grow's in marshy ground. Its stem is a kind of tuber, out of which long quill-like leaves proceed, having 
NATURAL SYNTEM.-FQUTSETACEA. 223

conceptacles of the seeds within the base of each. Pilularia, or pillwort, is also a British plant aflecting damp ground, and differs from the preceding in laving free or exposed conceptacles like pills in the axils of the leaves. Marsilea, or pepperwort, is an Italian plant, and resembles its congeners above, only it has but four leaves, or rather four leaflets on a stalk.

\section{LYCOPODIACEA.}

This order comprehends only two well marked genera, namely, lycopodium the club-moss, and psilotum, the woll-cluw-wort. In these genera the stem is elongated and trailing, throwing up slender branches, the apices being forked. The sporules are in the axils of bractea. Some of the species are useful as dyes, and others in medicine.

\section{FQUISETACEA.}

Of this order there is only one genus, of which there ure ten species described. They are aquatic plants, or live only on moist ground. Many of the species are British, where they are provincially known as jointed ferns, or horse-tail. The structure of their stems, or stipitella, is elegant, being regularly jointed, with whirls of leaflets or branches arranged 
like a cone. The fructification is seated on spikes at the tops of the stipitella. The stems are hollow between the joints; ind the interior surface is regularly decked with a deposit of flint, arranged in lines so closely set, that they take ard retain the form of the stem, when the vegetable matter of the stem is removed.

The next step we take in our advance towards the higher tribes of vegetation is to give a brief notice of that curious rustic genus of plants,

\section{FILICES.}

The ferns, it will be obserred, are placed ot the head of the cellular plants. They stand midway between the simplest and the more complex forms of vegetation. Though flowerless, and rising without cotyledons, chiefly cellular, they are much more highly organized than the orders already noticed, and much less so than the orders that are to follow. There are in the last published lists nearly three-score genera, and very near four hundred species, described. The stem is perennial, and creeping either under or upon the surface of the ground. In tropical countries some of the species are arborescent, and rise to the height of many feet. But whether tropical or extra-tropical, their foliage or fronds are all 
elegant in form, and curious in the manner of their erolution. In iestivation (that is, while enclosed in the bud) the points of the fronds, us well as those of the divisions and subdivisions of the sime, are rolled inwards upon their bases respectively; and their expansion is effected by unrolling in a very beautiful manner. The fronds, though mostly pinnatified, are sometimes entire, with reticulated reins. The capsules are usually round, brown spots rariously disposed on the under surface of the fronds, and sometimes compound on separate spikes.

Ferns are natives of every region of the world, and particularly of waste or unculti. vated lund. Nearly fifty of the species are natives of Britain. The adder's tongue (ophioglossum) is a small plant, and frequently found on clayey pastures. The largest of the British species is the osmunda regalis, or flowering fern; its root being used medicinally. The trichomanes and hymenophyllum ure beautiful plants, but only flourish in a wild state. One species of onoclea has fronds as delicately divided as the plumes of the ostrich, and has been specifically named sensibilis, shrinking as it is suid, from the approach of the evil doer.
The brakes or frondose ferns are only useful for litter, or for corering tender plints : one species, the aspidium filix mas, is inedicinal. The fabled Tartarian lamb is an aspidium, of which 
most wonderful tales have been told. A lisely imagination can make any thing of a grotesque looking plant, especially at shaggy fern. 'I'he Medico-Botanical Society of London possess a beautiful specimen of this fern; and, though it very curions production, it is no more like a lamb thun it is like a young bear; but when the fronds are cut off; the rhizoma, or horizontal stem, being shaggy, has some distant resemblance to the body of a fur or woolcovered animal.

The common engle-brake (Pteris aquilina) is one of the most common on our com. mons, and forms one of the finest corers for game; and their ashes, from the alkali they contain, are much used in the manufacture of soap and glass. The wall-fern, or polypody of the oak (polypodium vulgare), is nsed for the same purposes. See $f .4, P l$. 26, showing a portion of the extremity of a frond.

The ferns are arranged by cryptogamists into five tribes, namely, polypodiaceæ, gleichenicæ, osmnndacer, ophioglosser, and poropterides; which tribes are distinguished from each other by the forms and manner of opening of the conceptacles, or of the fructification being or not being compound.

Quitting the cellular grand division, we enter next on the simplest forms of the cotyledonea; that is, those plants which are partly vascular, and which rise from perfect seeds, with one or 
more cotyledons. Those plants which we are about to allude to rise with one seed leuf; hence the cluss in which they stand is called monocotyledonea.

\section{MONOCOTYLEDONES.}

The germination of the monocotyledons is exhibited thas: n spur-like process bursts through the cont or testa of the seed, and after heing more or less lengthened, turns downward into the soil, and emits a fringe of ront-fibres. In the mean time a bud appears upon the spurlike process, either close to the seed, as in the cocoanut, or nearer the fibrous end, as in pancratium and mistletoe, which soon bursts ind displays a single leaf, showing its classical chitructer. From the bosom of this single leaf other leares, and the point of the plumula, or young stem are evolved; the part behind the bud and empty testa rotting away, leaving the
young plantlet free and independent.

This mode of germination is the circumstance on which Jussieu founded the class monocotyledonece; and which is certainly a very natural mark of distinction, and designates all plants
belonging to it with great accuracy. 


\section{GRAMINEA.}

The grasses are one of the most common, and in their structure most simple, of all plants; but at the same time certainly the most universally useful. One hundred and fiftyeight genera, and above one thousand species, have been described. Here are lofty trees, as the hamboo, and the most lowly of herbs; the richest extracts, as sugar ; the most fiery spirits, as alcohol; and the most nutritious meal, as thut of wheat and other cereals. Equally important is the green carpet of the earth, Cormed by this social tribe of plants, which heeps our steeds, and fills our stalls as well as our garners. The grasses are too well known to require further description. See $P l$. 28, sweet-scented grass (Anthoxanthum odoratum), which imparts that grateful odour emitted by new-nown grass. Next to the grasses are placed the

\section{CYPERACEA.}

The sedges are somewhat similar in point of structure, but altogether different in point of value, being mostly worthless plants, inhabiling barren ground. There are above twenty genera, and nearly three hundred species. Some of them are useful to the mat and chair-makers. The papyrus, or paper of the ancient Egyptians, was manufactured from the stems of papyrus 
antiquorum, a common plant in the Nile. Some of the roots are fragrant; but they are a neglected, and by no ineans a farourite tribo of plants. Next to these come the

\section{RESTIACEA,}

Partaking the clinracter of the cyperacer, being rough inelegment plants found mostly in the southern parts of the globe. There are nine genera, none of which deserve particular notice.

\section{GILLIESIFA,}

An order containing only one genus, instituted by Dr. Lindley, and which, he says, is a small grassy looking plant, a native of Chili:its flowers are greenish yellow.

\section{JUNCE.E.}

The rushes are the next order of monocotyledones. They present us with the first aj)proach to a regular perianthium, as we ascend in the scale of regetation. There are seven genera, and above serenty species. Most of them ire worthless weeds, though some of them, as the xyris and narthecim, have pretty yellow flowers. Xerotes resembles a low palm.

\section{FLUVIALES.}

This order is a further advance towards 
complicated structure. They are chiefly, ts indicated by their title, uquatics; and lave separite flowers, one-seeded curpels, and intrafoliaceons vaginæ. The potumogetou, ruppia, \&c., are British plints, and common in rivers and ditches; and so are the lemna, or duck's-meat, which mantle every stagnant pool. Next to these we find the

AROIDE天.

The plants associated here give evidence of a further progressive change in organization. Among them we find pothos, dracontium, acorus, caladium, \&c.; also the well-known wake-robin or cuckoo-pint (Arum vulgare), See $P l .27 ; a$, the spadix surrounded by its spathe; $b$, stamens borne by the spadix on its higher part; $c$, ovaries inserted into the lower part of the same syadix; $d$, a berry ; $e$, a divided seed, in which is seen the cyliudrical embryo, in the middle of the fleshy perisperm. The roots of many of the arums are eatable after baking or boiling: those of the wakerobin are prepared and sold under the name of Portland sago; and the leaves of the caladium esculentum are used as greens in India. The above figure gires a good idea of the flowers of inany of the genera.

TYPHIN及.

This order contains only two genera, nanely, 
the reed-mace (typha), and the bur-reed (spar. ganium), which form together a type closely illied to the cyperales; for in the stamineous flowers the scales of the perianth are irregular, but in the pistilline ones the sepals are verticillate. The flowers are triandrous, single superior ovary, and pendulous solitary ovule. The typlas are not known to possess any properties diflerent from the ordinaly sedges, und are always found in company: it is the reed that painters usually figure in our Saviour's hand. The bur-reed is also found in pools, and is a rigid nseless plant. The next fanily of plants we meet with in our ascent is the

\section{PANDANEAE.}

The screw-pines, which are natives of the alluvial lands of Malaccil, and other parts of the East, are, when lull grown, magnificent objects. Their dense whirls of long narrow leaves, elevated on compound stems, give them all the port of palins. 'T'heir flowers are highly fragrant, and a valuable perfume is mamufictured from them. Plheir fruit is eatuble, but inferior, iund only used on occusions of necessity. The leaves are applied to many economical purposes, as basket-miking and thatching, and the soft spongy roots are nsed for corks. 'There is one other' genns (phytel phas), united with pandanus, but it is a less useful plant. 
PALM正.

'This splendid order of exotic plants were called by Linnaus the "princes of vegetation," and cortainly they well deserve the title. Whether we consider their altitude, their noble crown of fronds, their valuable fruits and use. ful timber, or whether we consider them us forming the finest feature in tropicul scenery, they are in every respect admirable. The palms were always considered as a distinct. order of plants, and distinguished by a peculiar name which they have always retained. They are arborescent, and, like the rest of their class, rise from the seed with but one cotyledon, as has already been explained. In general they have simple cylindrical stems, and rarely branched. The stem is formed of the bases of the leaves, these being permanent, while the points wither and consecutively drop off. New fronds are ever rising from the centre of the trunk, and therefore the latter is truly endogenous. The enflorescence is in large clusters or racemes, bractiated and often involred in a spatha. Each flower has a kind of calyx and corolla; the stamens frequently six, rarely three; the strles are three, often connate; stigma simple; germen superior, three celled, two or one of these cells often abortive; cells one-seeded. 
Palms differ, and are distinguished from arboreous ferns by their flowers, and from cycadacex by their endogenous structure and covered seeds. Forty genera, and one hundred and thirty species are illeady described in our recently published lists; and one traveller imagines that there are several hundreds in South America yet to be described.

'The date palm (Phonix dactylifera) is one of the most viluable as a fruit tree; as all over Syria, Arabia, Persia, and the neighbouring countries, it is a chief article of native subsistence both for man and beast, the camels being fed with bruised seeds. The cocon-nut (coccus nucifera) is also extremely useful to the inhabitants of the countries where cultivated or growing uaturally, which it does in many places of the East. Its nuts yield kernel, milk, and crean, as the difierent states of the hardening kernel are called; the shells serve for making small drinking vessels; a refreshing beverage (after fermentation) is supplied by the sip, which distils from the point of the excised racemes, called toddy; and from which an ardent spirit is procured by distillation. A raluable oil is expressed from the kernels; and the stem, from its great length and rectilinear form, is useful for edifices of any bind, the timber, though of very coarse grain, being very durable.

The Calamus scipionum, and C rotany yield the cames called rattans. The cable-cane ( $C a$ - 
lumus rudentum) exceeds in length all other palms, or perhaps, any nther vegetable; some have been met with five hundred feet in length. Like other reed palms they are applied to many useful purposes. Sago is manulactured from a pithy substance procurable from the stems of several palms, particularly from that of the Sagus Rumphii. The Raphia vinifera yields, when wounded, sap which when fermented is an intoxicating liquor. The doum-ptlm of Upper-Egypt is remarkable for its twice-divided stem, which is a rare characteristic in this tribe of plants. The doum-palm (Cucifera thebaica) also yields an useful fruit. One of the handsomest palms, the borassus $f a$ belliformis, bear's a very large fruit, and aftords an abundant flow of sap by tapping, and from which sugar is obtained, or fermented into wine.

The talipot palm (Corypha umbraculifera) has already been described: but there is another, C. Taliera, in Northern India, which is almost as useful as the talipot of Ceylon. The areca catechu affords the betel-nut, which is so much used as a masticatory or quid in India. $\Lambda$ slice of betel wripped in a leaf of the bete'pepper, enclosing a little chunam (red lime), is kept in the mouth for exhilirating the spirits, and for allaying hunger. Areca oleracia is the cabbage palm of the West Indies, the young heart lenves being used like coleworts. It is 

$=$

i. 1:

$\because 6$

i.

1

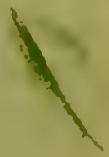

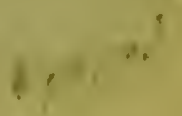

h. 

NATURAL SYSTRM. -BROMELACEA. 235

the tallest of all their palms, often rising two hundred feet high. Besides the abore, there are many other species which are ol the greatest importance to man, as furnishing him with so many dietetic and medicinal extracts, and materials for his convenience.

\section{COMMELINACEA.}

The next order above the palms is commelinuces, an humble tribe, but superior to the palms in organization. Eight genera are associated here, of which there are serenty species. They are mostly natives of Americn; and some of them, particularly dechorezandra and tradescantia, are fine flowering plants. As a type of the order, we gire a figure of the flower of the common spiderwort (Tradescuntia virginica), Pl. 2.9; $a$, summit of the stem; $b$, the calyx, stamens and pistils; $c$, the pistil only; $d$, the fruit surrounded by the persistent calyx.

\section{povtederex,}

A small association of aquatics, natives of America. Pontederia, heteranthera, and leptanthis are the generi, of which there are ten species. They are elegant in form, with cordate leaves, and centril spikes or racemes of blue flowers.

\section{BUOMELIACE.}

This order conprises several well known 
genera out of the twelve which compose the group. They are almost all rigid looking plants, with long sword-shaped, jagged, lepor. ous-coloured leaves, with minute white scales. The American aloe (Agave Americana) is a universally known green-house ornament, husing been long cultivated in this country, where they occasionally flower, and are exhibited as a rarity. As to the old error of these plants requiring one hundred years to perfect their flowers, it needs no contradiction; because in their native country they arrive at a flowering state in abont four years, and in this country they might be made to flower in as short a time, provided the necessary temperature were applied. In tropical countries very efficient hedges are made of them; although a gap is made by every flowering individual dying down with the stem, lenving only a small sucker or two to succeed. But the most celebrated plant in this order is the cultirated pine-itpple (Ananas sativa), which is now brought to so great perfection in this country by artificial means ; to a periection both in weight and flavour, far superior to any raised naturally in tropical gardens. The pine-plant is very fertile in progeny, multiplyiug itself by seeds, crowns, and suckers; and presenting the curious fact that its stem may be infinitely extended; there being no pause at the place where the flowers and fruit are produced, as is the case with the 
agare, and many other plants. It is a practice in Mexico to scoop out the central leaves of the agare to form a basin, into which the sap collects, to be ladled out as it is wanted for the labourers' drink. When this liquor is fermented, it is inebriating, and is called pulque, of which great quantities are made for sale. The Pitcairnia and Buonapartea, plants of no beauty, belong to this order.

\section{MELANTHACEA,}

An order of herbaceous plants with inconspicuous flowers, many of them possessing qualities of very suspicious character ; thongh these qualities are often found useful to the pharmacopeist; for instance, the veratrum and colchicum; the bulbs of the latter forming the base of the eau medicinale so celebrated for relieving the tortures of the gout. The veratrum is said to have been the hellebore of the ancients. Some of the genera have ornamentul flowers, as the uvnlaria and bulbocodium; but the generality are of little or 110 account.

\section{TULIPACEX.}

Of this gaudy order there are eight genera and as many as one hundred and twelve species described. The stately yucca or $\Lambda$ dam's needle, with racemes thickly hung with pale yellow bells; the branched lilies; the scandent 
gloriosa, the varied tulip, and the modest erythronium, are all denizens of the flower garden, and all favourite objects of the florist's care. They all are so much domesticated and so well known, that no particular description is required of them, especially as a type of the order has been shown on $\mathrm{Pl} .7$.

\section{ASPHODELF王。}

This is an order containing above fifty genera, of which there are above five hundred species, chiefly natives of temperate latitudes. Many of the genera are nearly allied to the order hemerocallidex, and a considerable portion bear some affinity to the tulipaceæ or liliaceæ. The species are all pretty, and many are handsome; some with bulbous, others with tuberons or fibrous roots. The hyacinth, scilla, and gagea, are among the beauties: the allium (onion), and asparagus, and phornium, the lily.flax, are among the most useful. They are mostly hexandrous.

\section{SMILACE.E.}

The plants in this order are rerging near upon the asphodelex as well in station as in organization. The genera are all curious; some exceedingly fragrant, as the lily-of-the-ralley; and others are elegant, as the trillium. The roots of several species form the sarsaparilla of the shops. 
TAMCA.

1 solitary genus of two species constitutes this order, showing it to be ol so peculiar a conformation that it camnot be associated with any other order. The Tamus communis is the black bryony of English Botany; a common hedge plint with climbing steins, and large tnberous roots.

\section{DIOSCOREA.}

'This is also a small order containing only three genera, of which there ale thirty-seven species. They have all climbing stens, with broad heart-sliaped leares and large fles ly roots. The yom is the type of the order, one of the most useful of tropicul esculents. The tuber is irregularly round, and as large as a child's head; the skin is rough and dark coloured, but the interior, when dressed, is mealy and beautifully white. Yams grow natmally in Ceyton and in Sumatra, and other oriental islunds; but are cultivated in many parts of India. Another curious genus belongs here, namely, the elephant's foot (Testudinaria elephantipes). The roots of this plant are slender fibres, proceeding from the tuber which lies on the surface of the ground. It is of a woody consistence and innually enlarged, the outer bark being regularly split into square 


\section{NATURAL SYSTLM.-AMARYLLIDACLE.}

lozenges, which every year become more projecting from the surface. Every year's growth is so visibly marked on the sides of the lozenges, that the age of the plant is ats truly marked as if written with a pen. By this means, some of the old wild plants at the Cape of Good Hope have been calculated at two hundred years old. The stems are slender and flexible, bearing heart-shaped leaves with racemes of small flowers in the axils.

\section{HEMEROCA LLIDEX.}

The hemerocallis, or day-lily, gives a title to this order; and as they may be met with in every garden, specimens of the flowers may be applied to for the character of the order. The type has many fine plants in its train ; the agapanthus, polianthus, blandfordia, aletris, \&c., are all choice flowering plants; then there is the numerous family of aloes, that are so curious in form, so gay in blossoms, and so valuable in medicine. The next order in our ascent, is one of the most splendid in the class, namely, the

\section{AMARYLIIDACEA.}

The genus which gives a title to the order is of itself so truly conspicuous and attractive, that it sheds a lustre over all its congeners. The amaryllis so significantly, in the language 
NATURAL SYSTEM. - H.TMONOUACEE. 2H

of Scripture, cilled "The Lilies of the Field," together with the narcissus, so rich in species, the universul favourite, the snow-drop, the magnificent doryanthes and pancratium, crinum, cyrtanthus and hremanthins inle all splendid plints. They are almost all bulbous, and their loliage is all very similar except in size. The colours of their flowers viry from white to the deepest scarlet, and muny of them are swectly scented. They are natives of every climate; und of all other tribes are easiest of cultivation. A few of the nacisisi are medicinal. and the juice of Jrunsvigia is poisonons.

\section{HYPOXIDE.E.}

The plants in this order were formerly associated with the asphodelea, hut withdrawn on account of the inferior ovary of hypoxis. There are only three genera herein included, namely, curculigo, molimeria, and lypoxis. 'The first and last, and their very few allies at present known, ure natives of New Holland, Indin, and the Cape of Good Hope. They are plants of sufficiently kiown, so thut their value has
never been ascertained.

\section{H.XIODORACEE} Are perennial herbiceous plints, with bun-
dled and fibrous roots. The leaves alternate, 
sword-shaped, and equitant, that is, riding on the backs of each other, like those of the iris. They are chiefly stemless, though some have dichotomus (twice divided) stems. This order stunds between iris and amaryllis, having some of the characters of hoth, without entirely belonging to either. Many of the species are showy; the roots of sereral, as hamodorum, wachendorfia, and dilatris tinctoria, yield a red dye, but they are not of much importance.

\section{IRIDACE.E.}

The iris or flowering-flag is a well known and beautiful family of plants, which are inhabitants of every quarter of the world. The crocus, gladiolus, tigridia, and numerous other allied genera, are highly interesting, easy of cultiration, and have a place in every flower-garden. In the genus iris, the whole of the six pieces of the perian th are highly coloured, the three outer, which are reflexed and form the calyx, most so; the three inner pieces are erect, answering to the corolla; within which there are three stamens covered by three petal-like pistils, which thus mark the transition of those organs into each other. Dr. Lindley says, their medicinal properties are trifling. Iris florentina and germanica have roots, which when dry smell like violets, and are slightly stimulant, acting as sternutatories or purgatives, according as they 
are employed. The stigmas of the crocus-sativus form the well-known saftron for which this species is cultivated. The ixias, watsonias, sparaxis, ferrarias, untholyzas, \&c., are the sparkling ornaments of the South $A$ frican meadows; and several beautiful irises are natives of Siberia.

\section{MUSACEA.}

The gigantic fruit-bearing herb called musa paradisaica gives title to this order, and with which only three other genera are united, namely, urania, strelitzia, and heliconia. They are all magnificent plants, both in flowers and folinge; and the musa, otherwise called the plantain or banana, is perhaps, one of the most valuable plants which can be cultivated near the residence of man in tropical countries. The are eatable, whether green, for baking or boiling, or when ripe as nourishing food. A plantain-walk is indispensable to every planter, and indeed to every house or hut in the West Indies; as there are always some of the plants in fruit, and when the whole vast bunch of ripe fruit is cut, the succulent stem, which nerer
flowers but once, is cut down, and sliced into
chaff or fodder for cattle. Th, chaff or fodder for cattle. There are many rarieties of the cultivated musa, that called the
plantain being the most robust grower, but the 
banana is said to have the finest flavoured fruit.

Although the plantain has been long in our stove collections, their cultivation as a horticultural luxury his been but sparingly followed, because of the great altitude of the plants requiring such lofty hot.houses. But this bar to their culture is now obviated, by the intro. duction, lately, of a very dwarf species or viriety, called musa C'avendishia, in honour of the Duke of Devonshire, in whose garden at Cliatsworth, the plaut was first fruited; and whose gardener, Mr. Paxton, is now cultivating the sort as a table fruit, with entire success.

The stem of the plantain when full grown is from four to eight inches in diameter, and rises from eight to fourteen feet high. The leaves are six or seven feet long, and two feet wide; very fragile in texture, and easily torn by wind. In a gale, the noise of a plantain walk is astounding : the foliage is shatlered to ribbons, so it is seldom we see a handsome or perfect plant in the open air.

The Strelitzias, named in honour of the late Queen Charlotte of England, hare rigid, smooth, spoon-shiped leaves: and their flowers of orange, and scarlet and white, are very brilliant. The fruits of some species of the heliconia and urania are eatable, but not so much esteemed as the banana. 


\section{CANNEX.}

This order occupies the first class and order of Linnaan Botany, and contains fire genera, and above four-score species. The camna, or Indian-shot, is a well known stove or greenhouse exotic, bearing spikes of scarlet coloured, irregular formed flowers, in which the filaments, insteid of being generally like threads, are what Botanists term petaloid, that is, resembling the petals of the corolla. The maranta arundinacia belongs to this order, and is the plant which contains so much nutritious facula in its root-stock, and from which the celebrated arrow-root is manufactured.

\section{SICTAMINACEX.}

An order of reed-looking plants, some of which are valuable for their fine aromatic pro. perties. There are eleven genera, and above one hundred and twenty species. Some of the ledychiums, alpinias, globbas, dec., are highly ornamental plants, and the most useful ones are those yielding ginger, galangale, costus, zedoary, and turmeric. The last is useful for dying yellow; and is also a principal ingredient, along with ginger, cardanoms, and similar spices, in compounding the famous curriepowder of the East Indies. They are all cul- 
tirated in our stove collections, or by artificial heat.

\section{ORCH I D A CEX.}

This is a very distinct and remarkable tribe of herbaceous plants. There are abore one hundred genera, and four liundred species already described. Some of them have tuberous stems, seated, and increasing theinselves in the earth ; many are epiphytes and grow on trees; and $\boldsymbol{u}$ few, if they by accident are suspended in the air, continue to grow and flower without assistance from the earth, or other substance. The leaves are simple, entire, alternate, either sheathing or articulated, with nervo-striated venation, and occasionally degenerating into scales. The sepals of the calyx are in general similar, the odd one uppermost; the petals of the corolla vary in form, the upper petal, which by the twisting of the seed-vessel becomes apparently the lower, is called the lip, as the two lower sepals, which become from the same cause uppermost, are named the helmet. The lip, or labellum, which is often lobed, and assumes a great variety of forms likened to flies, bees, men, monkies, was called in the Linn:ean school the nectary. The stamens are three, becoming by abortion two or one, united with the pistil, forming a fleshy column which surmounts the orary. On the apex of the column there is found a two-celled anther, and on either 
side an eminence marking the abortion of the other two. This is a distinction of one section of the orchidacex: another distinction is, when those which are abortive become developed, and others remain inactive. The pollen contained in the anthers is sometimes powdery and free, but more frequently waxy or granular, with the grains colnering in masses, and these have often prolongations called caudicula, or tails by which they are attached to a viscid gland. The formation of the flowers of all the orchidacere is so singular, and the mode of action of the organs upon each other is often so obscure, that much attention is required in the study of them so as to ascertain the tribes and genera to which they belong.

'The orchidacex are no less remarkable for their forms than they are admired for the elegance and rich beauty of their blossoms. Out of the most grotesque habit, flowers of matchless brilliancy of colouring are produced. 'The cattleyil is as vividly coloured as any other flower whatever; while some others are as hideously marbled with dull and lurid hues as can well be conceived. Almost all the South American species are remarkable, either for their modes of growth, distorted figure, or and beauty of our indigenous orchidacea, we have only to instance the lady's-slipper (cypripedium calceolus), a much admired plant; so 
248 NATURAL, SYATLM.- HVIROCHARIDACEA.

much admired, indred, even by the sheplierd boys, thut it is almost extinct, except in gardens where it is carefully protected. 'The orchis, of which there are so many species in our moist meadows, are rery interesting plants, and seldom escape the notice of any lover of flowers.

We present a figure of Epidendrum guttatum, $P l .30 ; a$, fragment of a stem; $b$, the pistil and stamen; $c$, the pollen. Vanilla is the produce of the old $E$. vanilla, it is used for flavouring cliocolate, and also for perfuming snuff:

OrderS JUNCAGINEA, and BUTOMEE, and ALISMACEA are three orders of aquatic plants. The first contains two genera of insignificant bog plants, with slender leaves, and central racemes of greenish flowers. The second contains also two generil one of which is the butomus, or flowering rush of English Botany, considered one of the most handsome of British plants. The third order contains three genera, namely, sagittaria, alisma, and actinocarpus. Some species of all three are frequently met with in ditches.

HYDROCHARIDACEE.

This is another order of aquatic plants, com prising four genera, and of which there are only fire species. Two of the genera, namely, hyIrocharis, the frog-bit, the water-soldier (Strutiotis), ne British. The other two ne fo- 
NATURAL SYSTEM.-HYDROCHARIDACEA. 249

reign; but one of them vallisneria, an Italian plant, hats something so curious in its history its to deserve remark. The plant grow's in rivers, and roots in the mud; the female flowers have long spiral peduncles, which can shrink or elongate themselves according to the depth of the water. The male flower's have no footstulk, but are sented on the crown of the roots. When the female flowers are ready to open, they mount to the surface to enjoy the light and heat of the sun, and there expand. Ahout the same time, the male flowers quit their hold below, rise to the surface, and floating loosely, are blown about by the wind anong the femule flowers, and where the necessary contact can hardly fail to take place. Dr. Durwin in his "loves of the plants," has the following benutiful allusion to this circumstance:-

“As dash the waves on India's breezy strand, Her flush'd cheek press'd upon her lily hand, Valisner sits, upturus her tearful eyes, Calls her lost lover, and upbraids the skies; For him she breathes the silent sigh, forlorn Eacl setting day; for him each rising morn,-
Briglit orbs, that light yon high ethercal plain,
Or bathe your rachiant trats Or bathe your racliant tresses in the main ; Pale moon, that silver'st o'er night's sable brow ;For ye were witness to his parting vow!

Ye shelving rocks, lark waves, and sounding shore, Ye echoed sweet the tender words he swore !Can stars or seas the sails of lowe retain ? O guide my wanderer to my arms again ?", 
CVEADACEAE.

When the contact has taken place, the female flower withers, and gradually sinks to the bottom, there to ripen and shcd the seeds. It was the opinion of the late Mr. Sweet, F.L.S., that this plant might be kept in a hot-house cistern, if roots or seeds could be had from Italy.

\section{CYCADACEN.}

This order contains only two gcnera, but they are very peculiarly formed plants. They can neither be called trees, nor shrubs, nor herbs. For though they have the uppearance of dwarf-palms, the interior fabric of their stems is totally different; showing them to be a connecting link between the dicotyledonous or exogenous, and monocotyledonous or endogenous structure. On this account they are placed among the most perfect orders of the class MONOCOTYuDONEx, in conformity with common usage; though there are well-founded doubts, whether or not cycadacere should not have been placed among the lowest orders of the DICOTYLEDONEA:

The genus cycas is a native of India, and of which there are several species. They have pectinated fronds expanded in the manner of some of the ferns; are very rigid and durable, and all evolved from the collet of the roots. The other genus, zamia, is fonnd at the Cape of Good Hope, and is an uncommon looking 
plant, throwing up consecntively, perhaps periodically, sets of harsh, pinnated leaves from the centre of a thick squat stem, shaggy with the remains of former leaves. The fructification is lateral, and diœcious, the flowers on both the male and female plants being borne on a spadix. These plants are in every stove collection, and kept more for the oddity of their forms than for their flowers, which are only interesting to the Botanist.

Having finished our review of the class monocotyledonex, it maly not be amiss to reiterate the chief characteristics of the cliss, and the order's it contains. The graud and principal distinction is, that all the dillerent plints rise from the seed dereloping one cotyledon only; or if there be two, the first is below the second; as sometimes, if not always, appeal's in the germination of the grasses. 'The second distinction is, that the growth is endogenous, all proceeding from the centre of the plant, or from the centre of each division of a compound plant. If the growth of a tulip, narcissus, an aloe, an orchis, or of the larger genera, the palms, or bananas, be observed, every new addition to the general bulk will be seen to proceed from the centre, and without, in many cases, any discernible lateral expansion. Another circumstance identifying the plants of this cliss is the venation, that is, the manner in which the petiole, if present, is divided and disposed through or along 
the web of the leaf. Throughout the class we have just been examining, the inain voins are seen to run parallel with each other from the base to the apex of the leaves; and this circumstance is often suflicient to indicate to the Botanist what class a given plant belongs to. The leaves of dicotyledonex hare alway's a principal midrib or costa, whence the veins diverge laterally, and very different from the parallel reined leaves of monocotyledoneæ. There is also in the latter a greater proportion of cellular inatter employed in their structure than is found in the generality of the dicotyledonea.

We now enter on a brief examination, or rather an enumeration, of the orders contained in the first class of Jussieuan Botany, namely dicotyledonea, or plants having a vascular organization, and rising from the seed with two or more cotyledons or seed-leares; and, agreeably to our plan, shall begin at the rear of the orders as they have been heretofore enranked. Not that those which we shall first have occasion to mention are more simple in their structure than those which we mean to notice last; but only for the purpose of winding up our review, where so many other writers have begun. We consider ourselves at liberty to do this, because we do not consider it essential to the use of the nuturul system to study it in that series in which it was first sketched by Jussieu himself, or as it now stands, as arranged by lis 
NATURAL SYSTEM.- MONOCHLAMYDEX. 253

followers; because there is no very apparent connecting chain so indicative of aflinity that confines, or should confine us, to the same orders as they are placed before us in books.

\section{DICOTYLEDONES.}

This class consists of two subdivisions; the second of which is again divided into three sub-classes, which shall be explained as we ur. rive at them; and first, of the

\section{SUBDIVISION MONOCHLA AYDEE.}

The title monochlamyder is a Greek compound, signifying one bed or coat, alluding to the circuinstance of the two outer coats of the flower, namely, the calyx and corolla, being united in one. 'I'his is a good and easily discovered distinction, and very useful in a systematic arrangement of plants. It is not subject to variation, except among highly cultivated plants; which cultivation very soon deranges the normal or natural forms of vegetation, a fact which is perfectly obvious in respect of many of the old denizens of our gardens. 
The first we meet with, is the

\section{EMPETREX.}

This order contains only three genera of dwarf heath-like plants, with minute flowers and berries. The crowbery (Empetrum nigrum) is a British plant, and common on the hills of the north. The white crow-berry is is native of Portugal.

\section{CONIFERI.}

If the preceding order is one of the smallest of shrubs, the present is one containing some of the most majestic and useful of our forest trees. The coniferæ, including the pines, firs, cedars, duc., seem to he peculiarly adapted as a clothing for cold northern countries, yielding necessary shelter for both man and beast. The North American species arrive at vast stature, some of them to ubove two hundred feet high. The spruce firs of the north of Europe are also very lofty; but the araucarias, altingias, and Cunninghamias of Australia, it is said, excel all in height and magnitude of their trunks. The Scotch fir (pinus sylvestris) is one of the hardiest and most uselul to the builder, as it furnishes all our yellow deal, which is at once ensily converted and very durable, in consequence of the great quantity of resinous sap with which the cellular and vascular members of the timber are filled. We have now, in our public nurseries and pinetums, a vast variety of 
species belonging to this order; and though many of them are heary sombrous-looking trees, some of then are highly ornamental, notwithstanding their formal outline. The deciduons cypress (Taxodium disticha) is perhaps one of the most truly beautiful of hardy trees; and in its native country arrives at the greatest magnitude, and the greatest age, eren hundreds of years.

'The coniferie are all monocious, bearing catkins of male flowers, and female cones containing naked seeds. When the male flowers are ripe, a puff of wind raises a cloud of the pollen, which may be seen in bright sunshine, flying at a great distance from the trees. 'The products of the coniferx, besides timber, are pitch, turpentine, Venice turpentine, gum sandurach, dic.; and a lew yield eatable seeds.

As an illustration of this order we have chosen the common yew, Pl. 44, (Taxus bac. catus); a, male cathin, scaly peltated anther; $b$, female catkin, magnified, and the same cut rertically; $c$, the onter scale; $d$, the cap)sule; $e$, the orary ; $f$, the stignia; $g$, glandulous tubers, surrounding the base of the cup; $h$, the capsula uncovered; $i$, the berry, cut vertically to show the pericarp; $k$, the grain.

HAMAMELT DEA. A sinall order of hardy shrubs, natives of
America, allicd to the order amentacea. The 
genera are hanamelis and fothergilla. The first has some inedical properties in its bark; and both are common in our shrubberies.

\section{AMENTACEX.}

This is a well defined natural order, the male flowers being all contained in aments or catkins. It is one of the most important of the class, from the number of useful species it contains ; indeed, we may observe, that all which it coinprises render, more or less, services to man. To this order belong all the lofty trees of our forests, and some of the small members of nur shrubberies. We are consequently indebted to it for much of our timber, useful for building, and in the arts.

Their flowers, always unisexual, are without a perigone, and contain, in the male flowers, a very variable number of stamens, disposed in cathins, as in the chesnut. The ovary of the female flowers is protected only by a loose scaly envelope: their alternate leaves are sometimes entire, and sometimes dentate.

These members of the regetable kingdom seem to dread the intense heat of a tropical sun, as but a small number are found in those regions, while they form dense and extensive forests in northern or temperate countries of the two continents: it is there where they attain to their greatest altitude, and acquire that substance and strength which renders them so 
NATLUAL SYSTEM.-IUGLANUIA.

useful for house and ship building. Their age it is difficult to determine; of some individuals their origin is lost in the ages of antiquity:

From its extent and importance, and, above all, from the dillerence of their botanical characters, the order has been divided into five sub-orders, namely, salicea, containing the willows and poplars; betulina, containing the alder, birch, hornbeam, hop-hornbeim and hazel; cuperliferece, containing the oak, beech, and sweet chesnut; platanece, containing plistamus and liquicl-amber; and lastly myricea, comprising the sweet gale, comptonia, and casuarina.

The above list of generi show's the vist importance of this order to the comfort, conve. nience, and protection of man; and, moreover, the fruits of some of them have been herctofore considered necessaries of life; and even now, cspecially in the south of Europe, chesnuts, acorns, filbert-nuts, and beech-mast, are still used as part of the labourer's fare, and in the desserts of the opulent. See Pl. 43, ha\%el-nut (Corylus avellana); $a$, fertile Howers ; $b$, sterile flowers ; $c$, a sterile flower magnified; $d$, a stamen mug-
mified; $e$, a fertile flower separate; $f$, a group
of nuts; $g$, one niked. of nuts; $g$, one naked.

IUGLANDEA

Include two genera of American trees, 
namely, iuglans, the walnut, and carya, the hiccory-nut. 'The nuts of the hiccory, as well us those of the well known walnut, are edible; and every where eaten us a dessert. These genera are separated from amentacex, because they belong to different orders of moncecia.

\section{PEPERACAE}

Contain three genera, namely, piper nigra or black pepper, so valuable in commerce; but which are very common looking climbing shrubs with inconspicuous flowers ; and piperumia, herbaceous plants of no beauty. "The pungen qualities of these berries, so useful as spice, especially in the warm countries, where these plants are natives, constitute their value. The black pepper is extensirely cultirated in India and the neighbouring islands, and forms a principal branch of their trade. Saururus, the lizard's-tail, is the third genus, and a native of temperate lititudes, but in qualities has nothing in common with the other two.

\section{ULMACE.E,}

(Or the elm family, are known by their definite perigynous stamens all fertile, a superiur two-celled germen, and solitary pendulous seeds, foliaceous cotyledons, with simple alternate, serrate, and stipulate leaves. The order contains only tluree genera, namely, celtis, 
planera, and ulmus. Of the last there are above twenty species, the chief of which are timber trees. The celtis or nettle-tree also yields timber when full grown; though there are but few such in this country. The planera is a deciduous shrub of neither much value or use.

\section{URTICE玨。}

This, as an order of the natural system, has been more carped at by its opposers thau any other; because of the genera associated in it being so decidedly dillerent in their appearance and products. It is the character and forms of their flowers, however, which brings these dissimilar genera together. Their enflorescence is somewhat amentacious, with definite stamens; germen superior, one-celled, and mostly oneseeded; leaves alternate and stipulatc; not lactescent, except in sume few instances. The greater part of the plants in this order are only weeds, having none of the loveliness of regetation in their composition; but this defect is abunduntly compensated for by a few associates of very great value, such us the fig, the iuulberry, and the bread-fruit (artocarpus incisa), us useful fruits; and the hop and hemp equally valuable for other purposes of man. The loathed stinging nettle, which is the type of the order,
throw's discredit over the whole assemblage. 
260 NATURAL SYSTLM.-EUPHORBIACEA.

\section{ANTIDESM ER.}

A small order of Indian trees, consisting of two genera, namely, antidesma and stilago. 'They are small trees or shrubs; the flowers in spikes; calyx, variously parted ; corolla, absent; fruit, drupaceous, hanging in clusters, eatable, but very acid, like berberries. 'The bark of antidesma is made into ropes, and also used medicinally.

\section{EUPHORBYACER.}

A large order, contuining forty-seven generi, and nearly four lnundred and fifty species. Their flowers, which are inconspicuous, are separate; germen, free, mostly three-celled; pendulous seeds with rough testa ; sap, with few exceptions, lactescent. 'The genera brought together here ale exceedingly various in aspect; some are lofty trees, others shrubs, of which the comnion box (buxus sempervirens) is a familiar example; those of northern latitudes are undershrubs or herbaceous. Although their milky juices are generally dangerous, many potent and excellerit drugs are extracted from one or other of the species. The poison found in inany of the euphorbias is dissipable by fire; the iatropha manihot, than which there scarcely. exists a more dangerous poison, when submitted to the action of fire, becomes imnocuous, 
and forms a untritious food called cassava, and which is sold and used in London for making puddings. Some species are called wart-worts, from the acrid juices being used to destroy warts. The seeds of the ricimus or palma Christi, yields the valuable castor-oil ; and many other drugs are extracted from the dillerent generi. In Africa and in India the leafless euphorbias are often planted as hedges; and from their prickles and irrituting juices are inpenetrable to both man and beast. Many of the European species are called spurges.

\section{CYTINEA.}

This order contains only the curious, but unsociable genus nepenthes, the Chinese pitcher plnnt. The enflorescence is in interminal spikes or racenes; the diocions, the perianth, inferior, and four sepaled ; stamens definite sixteen; united filments, and two-celled anthers. Nepenthes is a name of classic celebrity. Erery one who has read Homer's Odyssey must remember the passages in which nepenthes is mentioned as at charm for sorrow, or as an exhilirating or intoxicuting drink for assuaging pain. Whatever Homer meant by his nepenthes is now of little moment, but the plant is admired hy every lover of plants for the curious
form of its leaves. 


\section{ASARINA.}

'This is also a small order, embracing only two genera, of which there are thirty-six species. Asirum and aristolochia compose the order which is known by the definite stamens, variable in exsertion; a many-celled ovary; numerous ovules, subcentral placenta, and an included embryo. The species are mostly half shrubby plants, with simple, often kidney-shaped, leaves: mottled grotesque flowers, usually brownish purple. Arislochia sipho is the common birthwort, a large leaved climber met with in every garden. The A. clematitis is a British herbaceous plant found in woods.

\section{ELEAG NEA.}

An order of four genera and thirteen species. The genera have scaly leaves, the perianth scaly without, and persistent, corering the fruit when ripe, and the ovules and embryo both erect. They are mostly hardy shrubs or sinall trees; the flowers are incouspicuous but fragrant. 'The berries of hippopha, one of the genera, are used as a condiment in Sweden.

\section{SANTALACEX.}

An order containing seven genera and above twenty species. They are trees, shrubs, anil herbs with unattractive flowers, cliefly natives 
of Southern Africa, New Holland, and India. The wood of Santalum album, of the flower of which we anmex a figure, $P l .31 ; b$, a single flower; $c$, the culyx laid open; $d$, the pistil; $e$, the fruit ; $f$, the fruit cut vertically ; has a sweet aromatic flurour, and a sliglitly bitter taste; it is chiefly known as a perfume.

\section{THYMELE_E.}

An order of eleven genera, nearly all shrubby plants, found in all parts of the world. They difler from the preceding in having smooth leaves, the perianth coloured within and without, and not covering the fruit, the ovules pendulous, and the embryo inverted. The spurge laurel and mezereon (duphne laureola and mezereum), the lace bark (lazetta), and the leather wood (dirca), are the chief types of this order. 'They are all remukable for their acrid, or rather caustic juices, so that their leaves and bark may be used as vesicatories. The inner barks of the lagetta lintearia is the vegetable-lace, or Jamaica lace-bark; it consists of the annual layers of liber, and which are easily separated from each otlier, and may be made into any light ornament of dress. We are told that of this natural fabric, our Charles II. had a cravat, frill, and ruffles, presented to him by a Governor of Jamaica.

To give a better ideat of these monochlamy- 
dous flowers, we refer our fair readers to $I l .32$, which contains a figure of part of a branch of the mezereon ( $D$. Mezereum), sliowing first, $b$, a flower laid open; $c$, the same, showing the manner in which the stamens are inserted; $d$, the berry covered loy the perigone, in which it is entirely enclosed; $e$, the sime uncovered; $f$, the berry divided transrersely; leaving the seed half uncovered.

PROTEACEIE.

Protea, so named on account of the raried forms of foliage prevailing among the numerous species, is the normal genus of the type, which is internediate between the thymeleacere and santalacex, liaving like the former the germen free, and agreeing with the latter in the valvate astivation of the perianth.

The proteas are all exotic trees or shrubs, and almost all natives of the Cape of Good Hope, and New Holland. The leaves are without stipules and alternate, opposite or whirled; usually undivided, but sometimes toothed, rarely compound. The enflorescence is rariable, sometimes in spikes, panicles, or corymbs, or congested heads. Perianth four-leared leathery, coloured; stamina, four, opposite the lobes of the calyx; filaments short, anthers, adnate, and two-celled; germen free, formed of a single cirpel; the style simple, and the ovnles one or many. 
There are above thirly other genera associated with the protea, many of which are commenorative of eminent Botanists ; as Banksia, Dryandra, Knightea, Lambertia, Grevillea, dc. The telopea, one of the most splenclid flowering plants of New Holland is also here.

\section{MYRISTICEA.}

The plants composing this order are all tropical; of the several species of myristica, the common nutmeg ( $M$, moschata) is the most valuable. 'The flower's are dicecious, axillary, or terminal, collected in tufts or panicles ; the stamens are monadelphous; anthers, two-celled. The female flowers have a deciduous calyx ; the germen, free, formed of a single carpellum; the style, short; and the stigma, slightly lobed. The fruit is fleshy; the seed nut-like, and corered by a many-cleft arillus, which is the mace when separated from the nutmeg.

The nutmeg trees ale indigenous to almost all the islands in the eastern archipelago, both wild and cultivated. The wild ones are of a longer shape, and are often frandulently mixed with the true sort in the inarkets of Batavia, and elsewhere. The monopoly of the Dutch in nutnegs and other spices is now completely at an end; not only by the loss of their eastern colonies, but that the different plants have been 
introduced into every other colony where they will grow.

Hernandia, the other genus associated with the myristica, differs from it by its exalbuminous seeds; its species are arboreous plants, with simple, entire, alternate leaves, of a coriaceous texture. They are found both in tropical America and India; and some of them are medicinal. The juice of the leaves of hernauda sonora is found to be an advantageous and effectual depilatory, destroying hair wherever applied, and that withont pain. The colonists call it "Jack in a Box," and Botanists the specific epithet of sonora, in consequence of the whistling noise made by the wind blowing through its persistent involucels.

\section{LAURINEA.}

This rery important and highly ornamental order of trees and shrubs is not very far removed from myristica. Both produce the finest spices, and resemble each other in general aspect; but the flowers of laurus are bisexual, while those of the myristica are diœcious. The laurinea are all aromatic and uniform in their properties, they contain an essential oil, which gives them a warm and pleasant taste. The old genus laurus has been divided into three genera or groups, called laurus, persea, and cinnamomum. The first includes the bay and other laurels, 
with two celled anthers and naked fruit. The second the alligator pear; and the third, the cassia, the true cinnamon, and the camplior.

The laurus nobilis, sweet bay, is the only European species helonging to the type; and is still used in cookery for giving flavor to certain dishes, thougl almost superseded by its exotic congeners. 'The red bay, L. Borbonia, yields the isobella wood. L. chloroxylon and $\mathrm{L}$. Indica are both much valued for their timber. The sassafras of medicine is the wood of the $L$. Sassafras, a Chinese forest tree; and, in fact, there is not one of the species but

\section{POLYGONACE.E.}

An order of herbaceous, or half shrublyy many jointed plants, mostly natives of the northern liemisphere. There are foutem genera, and of which there are nearly two hundred species. Many of the last are worthless weeds; some are ornumental; but the most valuable are those which are medicinal or dietetic. For these purposes, the rhubarb (rheum) is the chief, and equally prized by the sickly as by the gourmand. The polygonim other northern parts of Europe it is esteemed as a bread-corn ; in France and England it is cultivated for cattle and poultry; and a strong spirit is obtained from the grain (called buck or 
beech-wheat) by distillation, and from which inuch of our ardent gin, rum, and brandies, is rectified and compounded.

\section{BEGONIACF:A}

Are semisucculent herbacenus plants, with juices not milky. Most of the species of this single genus are pretty, some very handsome, and, as they are mostly tropical plants, delight in warmth and moisture. The greater part of them are tuberous, with jointed round stems, alternate, simple obliquely lormed leaves, with free deciluous stipules; the flowers are monocious, itisposed in twice-divided, axillary cymes, the central ones male, and those in the circumference female; the bractea are coloured like the perianth, the two inner sepals being smallest; the stamens many, the anthers twocelled; the ovarium inferior, winged, and three-celled; styles three, very short, and the stigmas lobed; fruit capsular, crowned with the faded perianth; seeds many and small.

As the begonias are what may be called genteel looking plants, and often chosen for the embellishment of sitting-rooms, we wonld propose to the young Botanist the study of the enflorescence of this genus, as a most conspicuons eximple of moncecious flowers.

CHENOPODACEA.

An order embracing above twenty genera, 


and above one hundred species. From the shape of the leaves, this tribe of herbs are called chenopodium or goosefoot. 'They are generally weedy, mean looking plants, and as the wild ones are mostly seen on dunghills, this station adds nothing to their character. 'Though nearly allied to amarantlacear, the goosefoot is denied such brilliant colours, and therefore overlooked. Still the order has some redeeming characters; they are all innocuons ; and several of them are valuable, as decoctions of their leaves, or powdered seeds, or expressed oil, are all useful anthelmintics. Besides there is the invaluable cattle-plant, the beet, the bland culinary spinach, and the South American quinoa, or "petty rice," which proves a most nutritious food, are all of importunce more or less; and moreover, there are many of the wild and neglected species which serve poor people for greens when garden sorts are scarce. 'i'o give an idea of the flowers of this order, we have figured $P l .33$, a portion of the stem of water starwort (Blitum nirgatem), which is an European annual; $b$, a flower; $c$, the calyx; $d$, the fruit, all magnified; $e$, the fruit cut verticilly.

\section{PHYTOLACEA.}

An order of insignificant herbaceous plants, posiessing some medicinal properties, but of
no special interest. 
a MARANTHACEAD.

An order of sixteen genera, and one loundred and forty species, described in Botanical works. Many of them are cultivated for their deep crimson colomed flowers. The ligh coloured species are called amarants, or "undying ones" from the persistent calices retaining their colours long after the plants are dead. The prince's feather, love lies bleeding, the beuutiful globe, and splendid cock's-coinb, are all flower garden favourites. Several are used as pot herbs in India, but they are inferior to spinach.

\section{NICTAGINEA.}

With the exception, says Dr. Lindley, of Mirabilis, the marrel of Peru, in which the colonred calyx has a showy effect, all the order consists only of weeds. Uccasionally they have tuberous root-stocks and knotted stems. Their leaves are without stipules, opposite, rarely alternate, and almost always umequal. It is remarked of the marvel of Peru, that it opens its flowers at four o'clock in the afternoon; hence it is called "the four o'clock flower," in the West Indies. The abronias, another genus of this order, are delicate and beautiful plants, but of no known use. Pl. 34 shows dissections of the flower of the marrel of Peru (Mirabilis jalapa); $a$, a perpendicular section of a Hower, 
showing four of the five stamens, with the style and stigma ; $b$, " perpendicular section of the thick base of the calyx ; $c$, the nut, or hardened base of the colyx, contuining one ovule; 1 , the orifice where the coloured portion of the calyx is seated; 2 , the involucre.

\section{PLANTAGINCA.}

This is the last order of the sub-division 30 SOCHLAMYEX. It contuins only three genera, namely, plintago, littorella, and gliux. The plantains in general are considered as troublesome weeds, especially in turf, their broad radical leares growing flat on the ground, prevents the grow th of hetter lierbage. One species, the ( $p$. lanceolata), ribgrass, is sown on sheep pasture, as itretains its verdure in dry summers, when grass is withered up. The ( $p$. major), way-bred, so called from its prevalence on way-sides, is called the "Englishman's foot," in foreign countries; lor wherever it is found there our countrymen have trod. Glaux is the black saltwort of English Botany, and is common on the seal-shore. It is silid, that great quantities of the seeds of plantago arenaria are inported from France, for the purpose of forming an infusion in which muslins are wished. 
WE now enter upon an enumeration of the orders contained in the second subdivision of the second class, dicotyledonea, of the natural system. The plants in this subdivision present what is considered to be the highest degree of vegetable development: their organization is more complex; and their structure is more diversified.

We have already reviewed the simple forms of the division cellulares, and pointed out the homogeniety of their membrines. We next mounted a second step, to the monocotyledons, to show that their organization was superior, not only by a vascular apparatus being conjoined with the cellular, but by possessing certain foliar expansions which the cellulares have not; and which is signified by the terms acotyledons and monocotyledons. We, at a third step, entered upon the lowest subdivision of the dicotyledons, distinguished by their flowers having a single perianthium; and we now proceed to review the higher sub-classes of dicotyledonex, in which we shall hare to notice the lighest grudes of the regetable kingdom.

To prevent repetition, we may in the first place observe, that all the plants now before us are Vascular; that is, they are composed of cellular tissue, spiral and other ressels, and bundhes of longitudinal fibres. They rise from the seed furnished with two cotyledons, or seedleaves ; and their growth is exogenous, that is, 
NATURAL SSTEM.-GLOBURAIT.

the new accretions are formed on the exterior of the axis.

\section{SURDIVISION DICHLANYDEAT.}

The first class in this subdivision is distinguished from the other two classes by having the stamens of all the plants referable to it fixed on the corolla; which corolla is said to be monopetalous, and notattached to the calyx.

\section{CLASS I.-COROLLIFLORAE.}

\section{PLUMBAGINEE.}

' $T$ his is an order containing only three genera, but of which there are a great many species. Dr. Lindley sings, that it is properly placed on the confines of the monochlamydex and dichlainyder, because many Botunists consider it as referible to either. The different species of plumbago are remarkable for the acridity of their juices; and, as such, are nsed medicinally. Statice, the sen-litvender, ind armeria, the thrift, are many of them ornimental; and several species of both are British.

\section{GLOBULAR1.E.}

A solitary genus consititutes this order ; but there are ten species, and they are all pretty alpine plants; a few of them are under-shrubs; and though they are in the fourth class and first order of Linnaan Botany, they are not associable with any other orler. 
274 NATURAI SYSTEM.-IENTIBULAIE.

\section{PRIMULACEX.}

The genera of this order, anounting to seventeen in number, are almost all favourites. They are valued as much for their early advent as for intrinsic and modest beaty. 'The primiose, cowslip, and auricula; the androsaces, aretias, and soldenellas, are all inlubitants of mountains and meadows in all the tempernte regions of the northern hemispluere. Huttonia is a streamlet plant, and keeps in flower for several months, garnishing the sedge and grass among which it grows with its rosy blossoms. The cyclamen and dedecatheon belong to this order, enlancing the ralue of the whole by their presence. 'The tuber's of the former being eatell by swine in Sicily, caused it to be called sow-bread by the ancients. They are almost all spring-flowering plants, and easily cultivated.

\section{LENTIBULARIA.}

This small older contains two genera, namely, penguicula and utricularia ; are herbaceous, aquatic, or marshy plants, with a round stem, and alternate or whirled leares; and it is remarkable that tlose which are under water are compound, while those which are emersed are simple. The economy of the utricularia, in raising and sinking itself in the water, br means of its utricules or bladders being filled with 
water or with air, is exceedingly curious, and is one of those manifold proofs of design on the part of the Omnipotent Creator which we find continually exemplified in the most obscure and lowly members of regetable life.

\section{OROBANCHEA.}

A curious order of two parasite genera, both British plants, namely, the orobanche, or broom rape, ind the lathraa, or tooth-wort. The first is found either on the roots of common broom, or on those of the common broad or red clover. The orobanche seldom makes its appearance on clover until about the end of August, or Septenber; when, in some seasons, it rises in such abundance, as to very much lessen the second crop of clover. The stem and didynamous flowers rise like those of a branched, with narrow leares, or bractea ; colour of both flowers and bractea, a dull purple,
succeeded by capsules of many seeds.

The lathroea is found in woods, growing among decuyed leaves, and attuched to the roots of trees, on or by which it supports itself. This has also didynamous flowers.

\section{ACANTHACEAE.}

These are herbs, under-shrubs, or shrulss chiefly tropicul; the leaves opposite, simple, 
undivided, rarely sublobed, entire, or serrate. The enflorescence is terminal or uxillary ; bractea large and leafy, which enclose a diminished calyx; the flowers irregular and united; the cillyx is free; corolla below the germen and bearing the stamens; style one, and stigma two lobed; the fruit is superior, and mostly capsular and two-celled, spontaneously separating into two plates. The genus acanthus possesses some classical celebrity, from the legend, that its growing accidentally round a basket gave the original idea of the Corinthian capital in architecture. Thunbergia is a fine flowering genus, and also a climber suitable for ornamenting columns in greenhouses. All the acanthaceæ are known by the elastic valves of their capsules.

MYOPORINE.

An order containing four genera and eighteen species of South Sea and New Holland plants, remarkable for the smoothness of the stems and leares. Their leares are simple, petiolate; flowers without bractea; a dry unopented two or four-celled fruit, with one or two seels. The flowers are scirlet, white, or blue, and axillæary. The geuer il of this order are very near Verbenacex. Stenochillus is a handsome genus; and Aricennia tomentosa is the white mangrose of Brazil. 


\section{VERBENACE.E.}

'This order contains some rery fine flowering herbs, shrubs, and trees. There are twentynine generi, and nearly two hundred and twenty species. One of the lirgest forest trees known, namely, the teak (Tectona Indica) belongs to this order; as well as the Clerodendrons and Volkamerias of the same warm latitudes. The fine scented aloysia, and the humble verbenas of our gardens are universally admired.

\section{LA B I A T AE.}

Libiatx or lipped fowers, as some of those in Diandria Monogynia, and all the Didynimia Gymnospermia of Linnæus, are included in this very large order. The genera amount to seventy-eight, and the species to abore eight hundred and fifty. They are known by their four stamens being fixed on the corollat, with four naked seeds, single style, and irre. gular corolla. 'The order is divided in to seven tribes for the conrenience of stuclying and arranging the genera. The type of the whole is the well known mint (Mentha), hence the order has been called by some Botanists Menthacece. 'The rosemary, thyme, hyssop, lavender, \&c., are all cominon well known generu needing no description. 
SCROPHULARINIE.

This is another large order embracing almost all the plants in Didynamia Angiospermia of Linnaus. The fruit being capsular, and the didynamous stamens sufficiently characterise the genera of this order. They are chiefly herbaceous, and common in all parts of the world. Some of them are ornamental, as the Foxglove and Calceolaria; some are fragrant, as mimulus moschatus; and several are medicinal in small doses; and others, as the Digitalis purpurea, are dangerous. A great majority are weeds. The order has two sections, one having four, and the other, by abortion, two stamens only.

\section{SOLA YEX.}

An important order in several respects. Here we meet beauty and deformity: sanative vegetables and frightful poisons. The Petunia, Salphiglossis, Datura, and Brugmansia, drc., are admired as ornamental. The Atropa, Mandragora, Stramonium, \&c., are dreaded; while the invaluable potatoe (Solanum tuberosum) is cherished, and the nauseous tobacco (Nicotiana) is delighted in and relished as a spurious and deceptive necessary of life! The history of this last would fill a volume. Many tracts have been written against the use of it; even one of our sovereigns, James I., brand- 
ished his sarcastic pen against smokers, in his "cosinterblast," in which he denounces every ill upon the consumers of that deleterious weerl. "Now," says his Majesty, "to the corrupted biseness of the first use of this tobacco, doeth very well agree the foolish and groundless first entry thereof into this kingdome. It was neither brought in by king or great conqueror, nor learned doctour of physicke; with the reporte of a great discorery for a conqueste, some two or three siluge men were brought in, together with this savage custom. Bat the pitie is, the poor will balbarous men died, but that vile barbarous custom is yet alive, yea in fresh vigour;" and he adds, "surely smoke becomes a kitchen furre better than a dining chamber; and yet it makes a kitchen oftentimes in the inward parts of men, soyling and infecting them with an unctuous and oyly kind of soote, as hith been found in some great tobacco-takers that after their death were opened." Had his Majesty reigned at this time of our history, it is probable he would have found his own Chancellor of the Exchequer as much opposed to the disuse of tobacco as the monarch was opposed to its
consumption.

Besides the cultivated varielies of the $N$. tabacum, there are nuany other species of this genus, some of which are more ornamental than useful, and perennial instead of annual, us 
the great majority ure. Stramonium is as powerful a narcotic as tobacco, and is used extensively in medicine. Several other geners of this order are used for similar purposes as tobacco: the qualities of the majority being very much alike.

\section{HYDROPHYLLELE.}

Five genera are associated here, all rery pretty plants with opposite or alternate leares, a two scaled nectary at the base of each lobe of the corolla, and a one-celled germen. They have pentandrous flowers, either blue or pink, and are admitted into every flower garden.

\section{CORDIACEA.}

An order containing five genera of tropical trees or shrubs, the properties of which are not much known. Cordia is the principal genus of the order; some of the species of which, as C. sebestina and C. myxil, beal edible fruit. So are some of the ehretias fruitful, but their fruit is inferior, and in no estimation.

\section{BORAGINE.E.}

Contains twenty-six genera, of which there are above two hundred and serenty species. They are all innocuous plants, chiefly characterised by their mucilaginous properties, and 
SATURAL SYSTEM.TONVOLVILACL.J. 281

the occasional presence of colouring matter; hence some are used as demulcents, and some as dyes. The flowers are pentandrous, as may be seen by examining any of the wellknown plants arranged in this order. The cominon borage, which is found wild in England, is also in every garden. 'This and pulmonaria, and several others, were considered by the old herbalists as sovereign remedies for inany of the ailments of mankind. These plants contain a considerable quantity of nitre in their composition; to which is owing their cooling ellects in potations. The lithospermums (stone-seeds) are remarkable for their hard pericarps, which have the glossiness and brittleness of glass. 'The symphytums and cynoglossum were also accounted medicinal. The boraginea are found in every quarter of the world; the tournefortias and heliotropiums, being tropical; but the greater number are found in northern latitudes.

\section{CONVOLVULACE.I.}

A large order of twining plants, haring mostly fine showy llowers. The greater part are lerbaceous imnuals, several are perennial,
and a few are shrubs. Severnl useful drugs are
found in this order; as scamnonj, jalupg found in this order; as scamniony, jalup, tec., and also some articles of himan food, as the weet potatoe of America, ipomaa batatus, and 
the ipoman edulis of the south of Europe. The convolvolus is so well-known, and so commonly met with in gardens, fields, and on waste ground, that they need no farther description than what is presented on our I'l. 35, field convolvulus ( $C$. arvensis); $a$, the buse of the corolla, laid open to show the number and position of the stamens; $b, 1$, ovary, 2 , style, and 3 , stigma; $c$, a perpendicular section of the ovary, showing the ittachment of the orules.

\section{HY D ROLEACE正.}

A single genus constitutes this order ; there are only two species, but interesting, as, though they grow near water, their leaves appear us if smeared with oil. They are distinguished from convolvulace by their flowers huving two styles, and two-valved capsules.

\section{POLEMONIACEA.}

This order contains nine genera, and above sixty species. They are herbaceous plants with showy blue, red, or white flowers, and often with winged leaves. Many of them are flower garden favourites, as the phlox, the gillia, ipomopsis, \&c. Of these the enflorescence is in panicles, corymbiform, or somewhit capitate, and the pentandrous flowers are regulat and united. They are all rery hardy, and easily cultivated plants. 
NATURAL SYSTEM. -BIGNUNIACEL.

\section{SESAME.E.}

An order of tropical annuals, with trumpetshaped didynamous flowers, and simple leaves. The sesamum is called the "oily-grain," and is cultivated in India, and other warm countries. The oil is as sweet and tasteless as that of olives or ahnonds, and is expressed for domestic use. Herodotus mentions the esteem in which it was held in his time by the Babylonians; and Dioscorides says, sesame oil was highly valued by the Egrptians, who used it both to eat and burn, and their females as a cosmetic.

BIGNONIACEA, COBFACE.E, AND PEDALINE.E.

These thiee orders were united by Jussieu, but the two last have been separated from the first, and from each other, by modern Botanists. Bignonia or trumpet flower, and its allies, are trees or shrubs, with twining or climbing stems, opposite compound leaves, destitute of stipules, but often with tendrils. It is a large order, and is divided into seven sections, founded on the difference in the forms of their leaves. The tecoma radicans is often met with in gardens, and much aclmired for the beauty of its fluwers and pinnated foliage. The jacarandas, eccrimocarpus, and most of the other genera, are tropical, and though many of them have fine flowers and foliage, their uses are few. 
284 NATURA SYATLM.-ASCLEPIAIACLA.

\section{COBEACEX}

Contains only one genus, namely, cober scandens, separated fron bignoniacex, is a climbing genus with large purple flowers, and pinnated tendriled leaves, remarkuble for the rupidity of the growth of its shoots, sometimes extending above a hundred feet in a summer.

\section{PEDAL1NEA.}

Another order containing a single genus, namely, pedalium murex, the caltrops-fruited pedalium, also separated from bignoniacex, in consequence of the small number of seeds in each cell of the fruit.

\section{GENTIANACEA.}

'The gentians are mostly dwarf herbaceous plants, with deep blue flowers. They are all interesting, and some exceedingly beautiful; innocuous, but remarkable for their bitterness, which renders them, as medicines, tonic and stomachic. Erythrae, rohiria, chironia, spigelia, are all favourite plants. Villarsia and menyanthus are aquatics, and well worth a place in the flower garden.

ASCLEPIA DACEX.

This order contains forty-four genera, and above two luundred and sixty species. They 
NATURAL SYSTEM.-ASCLEPIADACEE, 285

are remarkable for the peculiar structure of their flowers; for, instead of the five stamens being free, they are mnited into a kind of fleshy canopy, or crown, subtending the germen. The pollen, instead of being pulverescent, is disposed in masses, like wax, as is observable in the orchidacex. Periploca is the only hardy shrubby genus of this order in our collections; all the others are foreign, though some of the herbaceous species ale placed in our flower borders. One of the most curious genera is the stapelia, chiefly natives of southern Africa. They are leafless plants, and are composed of a congeries of short rugged green stems, from among the bases of which the single flowers are produced on footstalks of various lengths. The flowers are of the most symmetrical forms, and of the oddest colours, and some of them, evolve such an abominable stench is even to attract the flesh-flies. On the other hand, the hoy'a, another genus, distils honey so copiously that, it is suid, wasps and bees, desert the sweetest ripe fruit to feast on the honey of the hoya. Pergularia, cynanchum, calotropis, and gyinnema, are some of the other genera, and are all very similar in the structure of their flowers. 'The qualities of the order in general, if not ictually poisonous, are at leust suspicious. Many of them, however, yield useful drugs, both emetics and purgatives. 


\section{A POCYNEAE.}

This is a large order, there being thirty-six genera, and above one hundred und forty species. Many of them are hirhly ornamental, and it may be said of them, that they are much more attractive in labit than amiable in qualities. Under the most gorgeous flowers, and foliage, there often lurk dangerous powers, liurtiul to animal life. One of their most striking characteristics in form is the twisted position of their petals, which lie oblicuely over each other, both before and after expansion. By looking at the flowers of the periwinkle (vinca), or at those of the lovely oleander (nerium), a perfect idea may be had of this obliquity of pelals which identify every genus of the order. Here we have the strychnos $n u x$ romica, or poison nut of Hindostan, so well known to the rat-catchers. Here are also cerbera, wrightia, echites, apocynum, and urceola, all more or less handsome plants; but all suspicious characters. We find here, notwithstunding, like all other dispensations and arrangements of Providence, a blessing amid those productions where danger might be apprehended. The nut of the strychnos potatorun is the cleansing-nut of India, and which has the rare and raluable property of purifying foul water so frequently met with in the tanks of 
that thirsty land. By rubbing the inside of a vessel with one of the nuts for a minute or two before the water is put in, however foul and muddy it may be, it is instantly cleared by the precipitation of the earthy matters to the bottom, leaving the water above transparent and wholesome. This is such a common practice in India, that the nuts are sold in every market for the pirpose, and always used by the officers of the army, when campaigning in that country.

The seeds of the cerhera (ominous name), and their milky silp, are so potent a poison, that a single seed given, or distributed in powder, is enough to poison twentymen. The apocynea are ilso dangerous plants; and from some of them caoutchonc is obtained; but this substance is chiefly obtained from valhea gunmifera and urceola elastica, for the European market. The vinca major, and the other species of periwinkle, are astringent; V. minor was the firourite flower of Jean Jacques Rousseau. Ophioxylon serpentinum is one of the snake-woods, affirmel to be antidotes to the venom of serpents. Wrightia tinctoria yields a valuable blue dye. The beautiful allamanda cathartica is medicinal, as well as both the plumeiera, alba and rubri. The strychnos, alluded to above, has been removed to an order in which it gives a title, namely, 


\section{STRYCISNERI,}

Containing, besides the type, fagrea and theophrasta, fine tropical trees, rearly allied to apocynex, and, like them, possessing dangerous properties.

\section{JASNINEF:。}

An order containing only two genera, but both farourites, wherever known, for their exquisitely fine scent. The jasmine is seen on almost every old cottage; and the nyctanthes is equally valued in every climate suitable to its growth. They are both natives of India, though jasminum officionale is quite hardy with us, retaining its Arabic name of yasmyn, nearly. The sambac of India (lyctanthes sambac) is sweetly scented, evolving its fragrance most powerfully during night; hence its generic name. This is a store plant.

\section{OLEINE.}

This order receives its title from the useful olive, a fruit tree of much importance in the south of Europe. Here there are eleven genera associated, of which there are about one hundred species or more. Besides the olive. we find several of our most common shrubs and trees, namely, the privet (ligustrum); the lilac (syringa); the ash (fruximus); phillyrea, \&c. The ash is hardly congenerous, as it has no 
coroll:s, and its fruit is a samara, that is, a closed, winged, one or two-seeded cilpsule, commonly called keys of the ash. In the privet the leaves are simple, and the lruit is drupatceous or baccate. A kind of wax exudes fro:n the Chinese privet (Ligustrum lucidum), which is used ecomonically in that country. 'The olea frigrans hits very sweet-smelling leires and flowers, both used by the Chineso in the manufircture of their teas. Ornus Furopari is the manma-ash, distinguished from fraxinus by its four-petaled corolla. This, and other species, rield that peculiar sweet cathatic, known in medicine under the mame of inanma. It is a prodict of the south of laty, wliere the trees are plentiful. Chionanthus, the fringe-tree, is from Sorth America, and makes a fine slumb. bery plant. 'The above Oleinea are all in diandria monagynia of Linnacus.

\section{BIREXIEAT}

1 solitary genus, of which there are three species, constitutes this order ; they are lofity forest trees, natives of Madagascitr, of which we have very good specimens in our stoves.

\section{СBEXIAC EAE.}

A grenus consisting of fom genela, and nearly torty species; some of which alp hardy trees and shrubs, with deciduons leaves and white 
flowers, natives of Norll Anerica, Europe, and New Holland; others are tropical evergreens. Of the latter, many of the diospjruses produce eatahle fruit, when fully ripe; they are commonly known as date-plums, and are in China preserved and used as sweetmeats. The wood of the black ebony (Diospyrus cibenum) is the most prized; but there are ebonies of other colours, as red, green, ind yellow. The true black sort is a mative of Madigascar, Mauritius, and Ceylon, whence our supplies are brought.

\section{SAPOTACEIE}

Are mostly shrubs, and trees, and ever-green natives of warm climates. They are chiefly valuable for their fruit; those of the inocarpus, achras, chrysophyllum, memusops, \&c., are all eatable. The first is the Tahite chesnut; the different species of chrysophyllum are the starapples and medlars of Europeans; achras sapota yields the sapodilla plum and naseherry; and much of the palm oil of commerce is believed to be yielded by the bassica, and other sapotacea.

\section{MYRSINE.E.}

This order, which contains eight genera of showy shrubs, with ever-green entire leaves, and cymes of white or red flowers, are all tropical. The ardisias are regarded for the beauty 
of their foliage; and the jacquinias are so ornamental, that the twigs of some of them are worn as garlands.

\section{STYRACINEJE.}

An order of two genera only, styrax and halesin. Of these there are seven species, all elegant trees, with white flowers. 'lie styrax is an Italian tree; the halesia North American. They are both hardy enough for this country, into which they hare been loug introduced." 'The first is a richly'-scented and beatutiful tree; the second, for its snowdrop-like flowers, is always seen in dressed grounds.

SYMPLOCINEE.

$A$ single genus, of which there are only two species of ever-green shrubs, with serrated leaves, and snall white flowers. 'The leaves of the symplocos tinctoria are used in America for dying yellow.

\section{EPACRIDACEA.}

An order of elegant shrubs natives of New Holland, which from their dry prickly habit and general appearance huve been culled the "Australian lieaths ;" as they are only distinguishable from the true heaths by being destitute of horns, or awus, on their antliers. Nliere are eighteen genera, and seventy-one species. 
'Their properties are scarcely known, but they are all very neat greenhouse plants with tubular flowers. Our notice of this order, finishes our review of the sub-class, Corolliflord, which, as before stated, is distinguished by the insertion of the stamens into the corolla. We next enter upon the sub-class CALYcrons, which contains all the dicotyledonous plants which have the stamens seated on, or inserted into the calyx. 'This is the principal mark of distinction.

\section{CLASS II.-CALYCIORAE.}

\section{PENEACEA,}

Containing eight species of beautiful shrubs, natives of the Cape of Good Hope. This genus is distantly allied to the Proteacese, and is distinguished from Epacridex in the calyx being of two leaves, and in the stigma being four-cornered, as well as in the fruit being fourvalved. The rezined gum called surcocol, is the produce of the Penæa sarcocolla and other species natives of Ethiopia.

ERICACFE.

This, collectively considered, is a very extensive order, and has so many alliances that it wiss very unweildy until rearranged by Professor Don. It embraces all the heaths, kilniiis, rhododendions, arbutus, gaultheria, dec, 
amounting to twenty-eight generı, and neal one thousand species, will varieties out of number. A monograph of this single orler would be a portly tome; so that our notice ol it must be briel. But if we only allude to the varied beanty and elegance of the 1 frican heatlis, and to the grandenr of the Emropen, Anerican, and Asiatic rhododendrons, azaleas, kulmias, dc., which are associuted in this order, our readers will reaclily agree with us, that there is no other order in the regetable kinglom which can be compared with this for varied beanty and splendour.

The only drawbilck against this fine order is that the honey exuded by the flowers of kalmia, rliododendron, \&c., ind collected by bees, is mnwholesomc, especially to children, to whom it is ndministered as a medicine. This has often been noticed in America, where these plants abound. On the other hand, the honey collected on our Britisli heaths is said to be the best in the market.

The lieatlis, strawberry-tree, with andromeda and menziesia, arc sufficient illustrations of the order Ericaceir. Bnt as pictorial illustrution is always satisfactory, we add a figure, $P l .36$, of Menziesia polifolia; $a$, a flower divided longitudinally; $b$, a single stamen; $c$, the pistil, surrounded by the calyx; $d$, the berry cut
transiersely. 


\section{VACCINE.E.}

Pretty little shrubs found in the northern parts of Asia, Europe, and America. The oxycoccus inacrocarpus produce the $\Lambda$ merican cranberries; and the oxycoccus palustris those of Europe. Vaccinium myrtillus yields the wortleherry. The order is distinguished by its inferior berry. The barks of these plants are esteemed as tonic medicines.

\section{GESNERIEX}

Is an herbaceous order, mostly found in woods in tropical America. They have large radical leaves and flowers, either blue or purple. The gloxinea is one of the most conspicuous genera; and is a good type of the order.

\section{CAMPANULACEE.}

This order is chiefly herbaceous, nearly two hundred species being hardy. All the genera, of which there are eleren, are pretty, and some, especially the campanulas, are highly ornamental. Their anthers are mostly distinct, their fruit many-seeded, and some of them exude a milky juice. The rampion (Campanula rapunculus) is a culinary vegetable, the ronts being esteemed a delicacy. We give a representation, $\mathrm{Pl} .37$, of the Throat- 



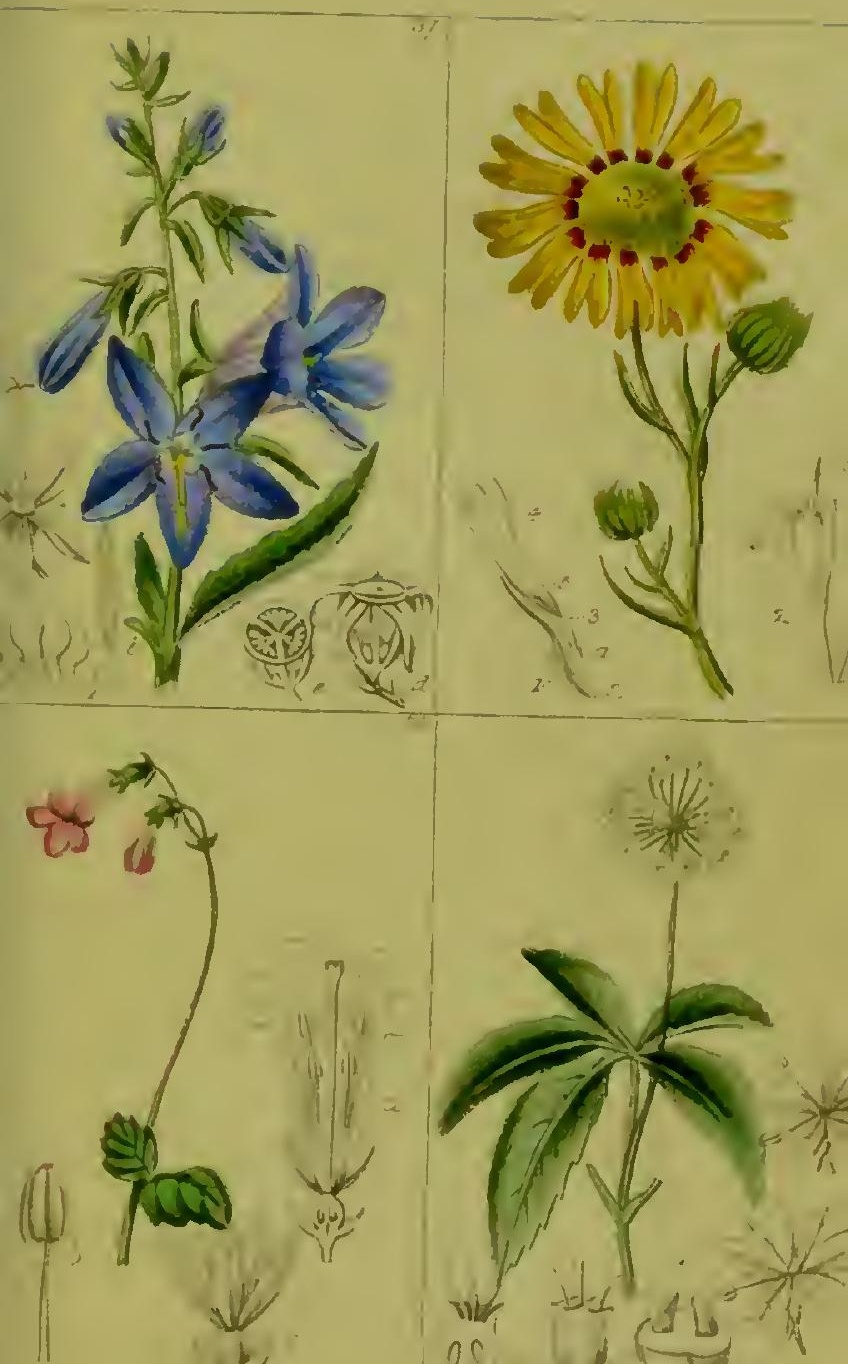



wort (Campanula trachelium); a, position of the stimens at the base of the corolla; $b$, $a$ stamen magnified; $c$, the pistil ; $d$, the fruit ; $e$, the fruit cut Iransversely.

GOODENOVIE.

Consist of New Holland herbs or unclershrubs, nearly allied to the curious order Stylidea. 'They are all interesting little plants and worth cultivation. The flowers are pentandrous.

\section{STYLIDEJE.}

This order comprises only one genus, but it is a very remarkable one. 'The flowers are gymandrous, the stamens and style being united. They have pink-coloured flowers covered with glittering glunds; and such is the unusual form of the organs, that Botanists have been led into error. The pistil is so concealed by the stamens, that hy Labilliardiere and L. C. Richard it was wholly overlooked. 'T'he irritability of the stigma is physiologically curious; if the stigna be tonched by a pin it instantly starts from its place with great elasticity.

\section{LOBELIACFX.}

This order was distinguished by Linnaxus, under the title Monogamia, because its single (not composite) Howers had the anthers uniled in a cylinder, like those of the florets of the 
cluss Syngenesiat. Motern Botinists hase erected it into an order of the natural system with much propricty, because no mistalke cin be made in identifying the genera. They ate all fine ornamental plants, wilh blue, white, or scarlet flowers. The lobelias are universal firourites, although the qualities of some of them are deleterious.

\section{CONPOSITA.}

'This large natural order includes all the syngrenesious plants of Limnas. 'T'here are no less than two hundred and ninety-six genera, and two thonsand seven hundred and serentyone species enrolled in recently pub'ished lists. All gratiations, from the ample sunflower down to the minute daisy, are met with here. It is: it conspicuous natural order, which Tourneforte arrunged in his radiati, Linnacus in his clitss syngentsia, ind Jussieu in the present order composita. It is divided into nine suborders, with appropriate tilles, and these again into numerous tribes. Without such a classification, the order, being so unwieldy, would be difficnlt to study and arrange. Yellow is the predominating colour of the flowers ; and, from the circumstince of many of them being so common in the northern hemisphere, in meisdow's and pastures, they attract but little notice. But a $\mathrm{f}$-w foreigners are highly prized, as the 
dahlia, the Chinese chrysanthemums, the marigold, coreopsis, and calliopsis, dec. We give a figure of a very hnndsome Chilian genus (Madia elegans), on $P l$. 38; a, i floret of the ray; 1 , a portion of the involucre attached to the buse of the ovary, 2; 3, the tube of the corollet; 4, the lip or limb of the same; i), the style, bearing two stigntas; $b$, a floret of the disk; 1, pappas; 2 , the tube of corollet, divided into fire equal segments; 4 ,

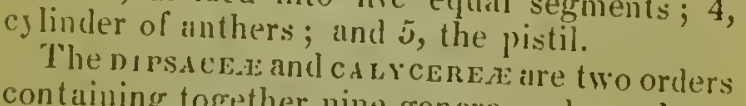
containing together nine genera and one hun. dred and nine species, neirly akin to compositic, of which they have a similar habit. All all" lierbaceous, with flowers growing on heads. The genus scabiosus is a good representative of the order; and, as they are in every garden,
inay be easily referred to.

\section{VALERIANACEA.}

Small herhaceous plints, without altraction in the eye of the florist. 'They are, howerer, neat, and some of them are uselul as salad plants. They are annuils or peresunials, and they have been long extolled for their medicinal properties. The roots of the perennial sort.; cspecially those which grow in dry situations, we aromalic and highly stimnlating, and are used! freely in hysterical calses. 


\section{RUBIACER.}

Rubia, the generic name of the madder, so) uselul to the dyer, gives a title to this order, one of the most important in the natural system. 'The genera are known by their opposite entire leaves with intervening stipules, a monopetalous superior corolla, a definite number of stamens (four), and a two-celled ovarium. The order includes liumble weeds and Jofty trees, medicinal qualities, and flowers of gayest colours. The order is divided into nine sections, but they are chiefly artificial. The plants of beauty and value are innumerable : of the former, the ixora, bourardia, catesbcea, Portlandia, \&c., are examples: to the latter every genus has a contribution of one kind or other. Many are dye-stuffs; and, among medicines, the cinchona, or Jesuit's-bark, is invaluable; so is the ipecacuanha; and last, not least, the excellent coffea Arabica. The rubia and galium are the representatives of the order in Britain.

CLORANTH I:A and LORANTHEE are two small orders: the first are inconspicuous shrubs, with terminal spikes of green flowers of no interest. The second contains two genera of parasitic plants; nainely, loranthus, the foreign, and viscum, the English mistletoe. The latter are of no great beauty; but the tropical loranthe:c are scarlet flowering plants of the greatest splendour. The loranthus is not in our 
collections; though it is supposed they were once natires, but disappeared with the Druids.

\section{CAPIRIIOLIACEA.}

So called becanse some of the species climb like goats; for instance, the honeysuckle (caprifolium). This order contains eleren generi and above one hundred species. The honey'suckles, of which there are numerous species, need no description, being not only in every hedge but on every house. The cornus, elder, guelder rose, \&c., are all common in our woods. 'The lonicera are exotic shrubs, some of them having handsome flowers. But the most celebrated genus, though it has neither bulk nor beauty to boast of, is the Limoa, in insignificant memo. rial of one of the greatest naturalists that ever lived, Curl von Linné. That this plant muy be better known, we hase added a representation of parts of the Linncea borealis on $P l .39 ; a$, a flower cut transiersely; $b$, a stamen magnifiel; $c$, the ovary surmounted by the calyx, also mignified.

\section{ARALIACEAE.}

The plants in this order might be mistaken for a branch of the umbelliferx, with which they nearly agree in habit, except in being usually shrubby, as well as being distinguished by their five-celled fruit. Their flowers have no beauty, but their foliage is fine. 'The most 
familiar type of araliscea is our comnon ing. Some of them yield an aromatic gum resin; and the famous Ginseng is produced from I'anaxquinquifoliu, of which we give a figure, $P l .40$; $a$, an hermaphrodite flower magnified; $b$, it male flower magnified; $c$, a stamen magnified; $d$, the calys and pistil; $e$, the same cut transversely; $f$, the fruil cut transversely.

\section{CUNONIACEA.}

This order was formerly associated with the saxifrage till separated by Dr. Brown. They are shrubs with pinnated leares and white or red flowers. 'Two of the genera, callicoma and batuera, having simple leaves, are estimable greenhouse plints.

\section{SAXIFRAGLAE.}

The break-stones are liumble herbaceous plants usually found on rocks, old walls, or ruins of buildings. They are inhabitants of temperate or norihern climates. Their flowers are decandrous, and have two styles; very symmetrical in form, but seldom highly coloured. There are ten genera in the order, and one hundred and forty-two species; the latter chiefly saxifrages. The well known hydrangea is here, hul, it is said, misplaced.

Grossulariex and Escalloxise are two orders with each a single genus. The first 
NATURAL SYSTEM.-IICOIDLE.

engrosses the genus ribes, the well kuown gooseberry and currants; the other a South American shrub sonewhit similar to vaccinia.

CACTEA OR OPUNTIACEA.

A remarkible order of succulent plants, destitute of leaves, but many of them having fluttened stems or a profusion of spines, which probably answer the sime purpose. Many attain a considerable height, assuming most fantastic shapes, and are called torch-thistles. Some of the cacter, as the cereus for instunce, have most magnificent flowers, equal to m!y other flower whatever. 'The opuntia cochinillifera is the plant on which the coccus, that is, the cochineal insect, is bred, and from which this valuable colouring substance is collected. The melocactus and mammalaria have curions depressed stems, regnlaty corered with rigid spines. Some of them yield eatable fruit, which are eaten more for their refreshing cool. ness thin for any otlier excellence.

\section{FICOIDE-T.}

These are called fig-marigolds from the shape of their stems, and form of their flowers. The niesembryanthemums are a very numerous fitmily of succulent plants; the leaves are fleshy, and of every imaginable shitpe. Their Howers though not so large as those of the cereus ane 
302 NATURAL SYSTEM.-PARONCHIEE.

equally rich in colour; some of them presenting the richest metallic brilliancy under bright sunshine. 'They are mostly dry store plants. Tetragona expansa, a hardy annual, is eaten like spinach.

\section{CRASSULACEA.}

Another very extensive order of half succulent under shrubs. They have beautilul scarlet, orange, yellow, or white flowers, and are natives of every quarter of the globe. This order is distinguished from ficoidex in the embryo being straight, not curved. The leares of some of these plants are physiologically remarkable; the upper leaves or bractea of the echeveria, if laid on the surface of the earth, strike root and become new plants; and the leaves of bryophyllum bear viviparous progeny on the edges, whence they drop off and take root in the ground.

PORTULACEE.

An order of ten genera, and above fifty species. Except talinum and calandrinia, and a lew species of claytonia, the majority are worthless weeds. The portulacen sativa is the common purslane, the only useful herb in the order.

\section{PARONYCHIEE}

Is an order, which only differs from portulacea by the stamens being opposite the lobes of the 
calyx, not alternate with them. Corrigiola, telephium the orpine, and some species of lahayn, are the principul genera.

\section{LOASEA AND TURNERACEA.}

Two small orders of plants, nutives of tropical America. The first contains five genera of succulent cut-leaved plants generally covered with stinging hairs. Some of them are climbers and mostly annuals. Turneracea has one genus of annuals and undershrubs. It dillers from loasere, in the stamens being equal in mum. ber with the petals, and inserted at the bottom of the calyx, not in the throat of the tube as in the first order.

\section{PASSIFLORE.E.}

The singular form and arrangement of the flowers of this order, their gaudy colours, and their symbolic character and history, make thein universally regarded. There are five other genera associated with the passion-flower ; all being climbers, and nutives of the tropics. Some of the passion-flowers yield eatuble fruit. $P$. malatormis is the sweet calabash of the West Indies, and is a good dessert fruit. Many of the species flower freely in our hotlouses, and sometimes ripen fruit.

CUCUIL BITACEA.

This is the order which includes all the gonrd, nelon, and cucunber tribe. They are 
climbing plants having tendrils by which they atlach themselves to other plants for support. 'Their fiowers are monacious, and they are decidedly herbaceous except onc, the carica palpay, which has the port of at tree rising from ten to fifteen feet high, bearing large fruit like melons, but not half so good. All the eatable species are most useful in tropical countries, where every kind of juicy wholesome regetable is valned. But they are not all wholesome; the coloquinticla gourd, the squirting cucum1ber, and the tricosanthis amara, are all possessed of violent purgative qualities. It is observed of these last named plants, that though the pulp is disagreeable, the seeds are sweet and paliatable. Bryony is a British genus, but it is useless, having only some obscure medicinal properties.

MYRTACEA.

The common myrtle is the type of this beratiful and useful order. It includes thirly-seren genera, and very neal three hundred species. The inyrtacese are known by their dotted leares with marginal ribs, an inferior ovarium, and single style. They are all evergreen trees or shrubs with white flowers, and some of them bear pleasant fruit. The order is divided into five tribes and two sub-tribes. The allspice and the clove are valuable spices. The euginia, jambosa, and gauras are excellent fruits. Mnst 
NATURAL SYSTEM, - MELASTOMACEA. 305

of the genera yield a fine aromatic oil; that of the melaleuca lencolendron is the famous cajeputi. A similar rich oil is procured from the clove; indeed the whole order is of primary importance.

\section{PHILADLLPHEX}

Is a small order separated from myrtacea by Professor Don. It contains philadelphus coronarius, the mock orange of our shrubberies, of which there are several species; and decu. maria, an $A$ merican climber of no beauty.

\section{A LANGIE.E}

Is another order separated from myrtacex, because its petals are more nnmerous, its anthers adnate, und its fruit being one-celled. It is a native of India, where the fruit is considered good and wholesome.

\section{MELASTOMACEA.}

An order contuining twelve genera, and near eighty species of beautiful trees and shrubs, with large white or purple flowers, and leaves with several, generally three, costa. The fruit of the melustoma is a fleshy insipid berry; eatable, hut stains the teeth and mouth black; hence its generic nune. The beautiful little rhexias, herbaceous pretty plants from Carolina,
belong to this order. This order is only re- 
moved from myrtacex because of their want of essential oil, and of the dot-like reservoirs of the leares and other parts which contain it.

\section{LYTHRARICA, OR SALICARIX.}

Genera eleven, species sixty-one. Most of these, says Dr. Lindley, are very showy plunts, particularly lythrum and lagerstrœmia, which are the representatives of the order. The lythrum salicaria is an English plant, found on the banks of rivers, bearing long spikes of purple flowers. The lagerstrœmia is one of the most heautiful Indian shrubs. Peplis (the water purslane) is British. Lawsonia is used by the Turkish women to stain their nails; and several of the species are medicinal.

\section{CERATOPHLLEA.}

An order formed for the purpose of comprising a single genus of two species of British plants, namely, the hornworts, ceratophyllum, demersum et submersum; common in ditches every where.

\section{ONAGRARI王.}

A pretty extensive order, containing fourteen genera, and nearly one hundred and filty species. It is well defined and known by its pollen cohering by slender threads; by in inferior polyspermous ovarium; a fonr-sepaled calyx ; and four-petaled flower, with a definite number 
NATURAL SYSTEM.- COMBHETACEAE. 307

(eight) of stumens, and a single style. Most of the genera are hnndsome. The epilobium, cenothera, Clarkia, and fuchsia, are ull eminently ornamental in our flower borders; trapanutans yields an eatable nut, of much service to the poor where the plants ure wild; trapa bicornis is a common culinary regetable in China. The anothera biennis is the evening primrose; and which las many new and beautiful congeners.

\section{HALORAGEAE}

Is an order of seven genera, nearly allied to onngraria, and only distinguishable by its naked and solitary orule. 'The genus calitriche is British, and found in ponds and ditches frequent.

\section{TAMARISCINEE.}

An order which differs from onagraria in the ovary being free, and in the imbricate xstivation of the calyx; and from lythrarica, in the petals being inserted at the botton of the calyx. T'he tamarisks are shrubs with twiggy branches, sinall scale-like leaves, and white or rose-coloured flowers, disposed in branched spikes; comnion in our shrubberies.

\section{COMBRETACEIE.}

This order contains seven genera, and nearly forty species. It is divided into two tribes,
$\times 2$ 
namely, terminalix and combretex. The juice of terminalia vernix is a Chinese varnish; the bark of buceda is used for tanning leather in Guiana; and the woods in that country are festooned with the deep-coloured flowers of those fine climbers, the quisqualis and combretex.

\section{VOCHYSIACEX.}

A single plant, agrees with combretaceæ, in having convolute cotyledons and inverted seeds; and with onagrarix, in the flowers being monandrous; or if triandrous, two of the anthers are always sterile.

\section{RHIZORHOREE}

Is a genus, the growth of which has already been alluded to.

\section{GRANATE王}

Contains only one unsociable genus, namely, the well-known pomegranate (punica granatum), so called from its resemblance to in apple full of grain. This fruit tree is a native of the north of Africa, where it yields abundantly; but though esteened by the 'Turks and other inhabitants, it is certainly inferior to the orange; the flowers are scarlet, and very ornimental in this country, when planted in farourable situations. 


\section{MEMECILEX}

Is a doubtful order, of three genera, natives of the tropics; the fruit is suid to be useful, tlough very acid. Memecylon, mouririn, and scutula nre the genera; nll of which are distantly related to granater, nielastomacer, as well as in some particulurs to inyrtacex.

\section{CALYCANTHACE X:}

Beautiful hardy early-flowering slurubs, natires of North America and eastern Asia, with sweet-scented yellow or dull purple flowers. They differ from rosicea, in the form of the embryo; and from granate in the embricate astivation of the calyx; from both, in the absence of petals, and in the numerous divisions of the calyx.

ROSACEX.

This very large, and, in many respects, most important order, consists of forty-six genera, and no less than seren hundred and eighty-three species in our modern lists, besides a more than equal number of varieties. The admirable rose is the type of the whole; which on examination will be found to have petals inserted into the calyx; which last is five-sepaled, the fifth, or odd sepal, being axial, or posterior ; the fruit a drupe, pome, or nkenium; the seeds exalbuminous; and the embryo straight. Beauty of flowers is one characteristic of the order; 


\section{NATURAL BYSTEM.-LEGUMINOSA.}

bul it is not for the charms of scent, or blossom, or foliage, that this order has gained for itself the estimation of mankind. It also includes all the most valuable fruits of the temperate regions of the earth. It may only be necessary to mention the almond, apple, pear, plum, apricot, cherry, peach and nectarine, loquat (a Clinese fruit), medlar and quince, together with the humble but luscious strawberry, besides many other fruits in tropical countries.

\section{LEGUMINOSI.}

This legume, or pod-bearing order, is one of the largest in the natural system. It contains, in our lately published lists, two hundred and forty-four genera, and two thousand six hundred and twenty-six species. Collectively they have been called leguminosæ, from the shape of their fruit; and, by the earlier Botanists, papilionaceæ, from the form of their flowers resembling a butterfly. These characteristics are familiar to everybody, and facilitate the arrangement, as no notice is taken of the number or position of the stamens, dcc., as is $^{\circ}$ done in Linnzean Botany. The loftiest trees, the densest slirubs, and the humblest herbs, are found in this order; and, notwithstanding their diversity of stature, their flowers are all very similar. The order is divided into two divisions, namely; curviubria (crooked pods), and rectembria, straight pods. These are 


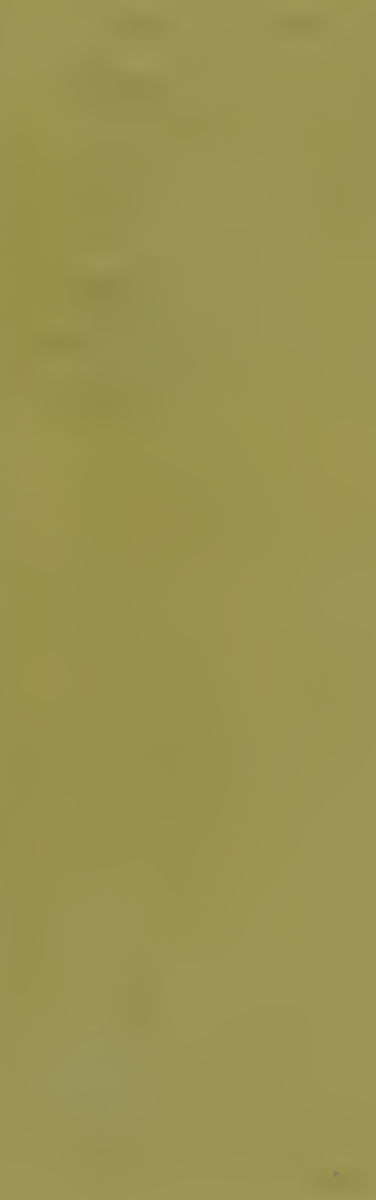




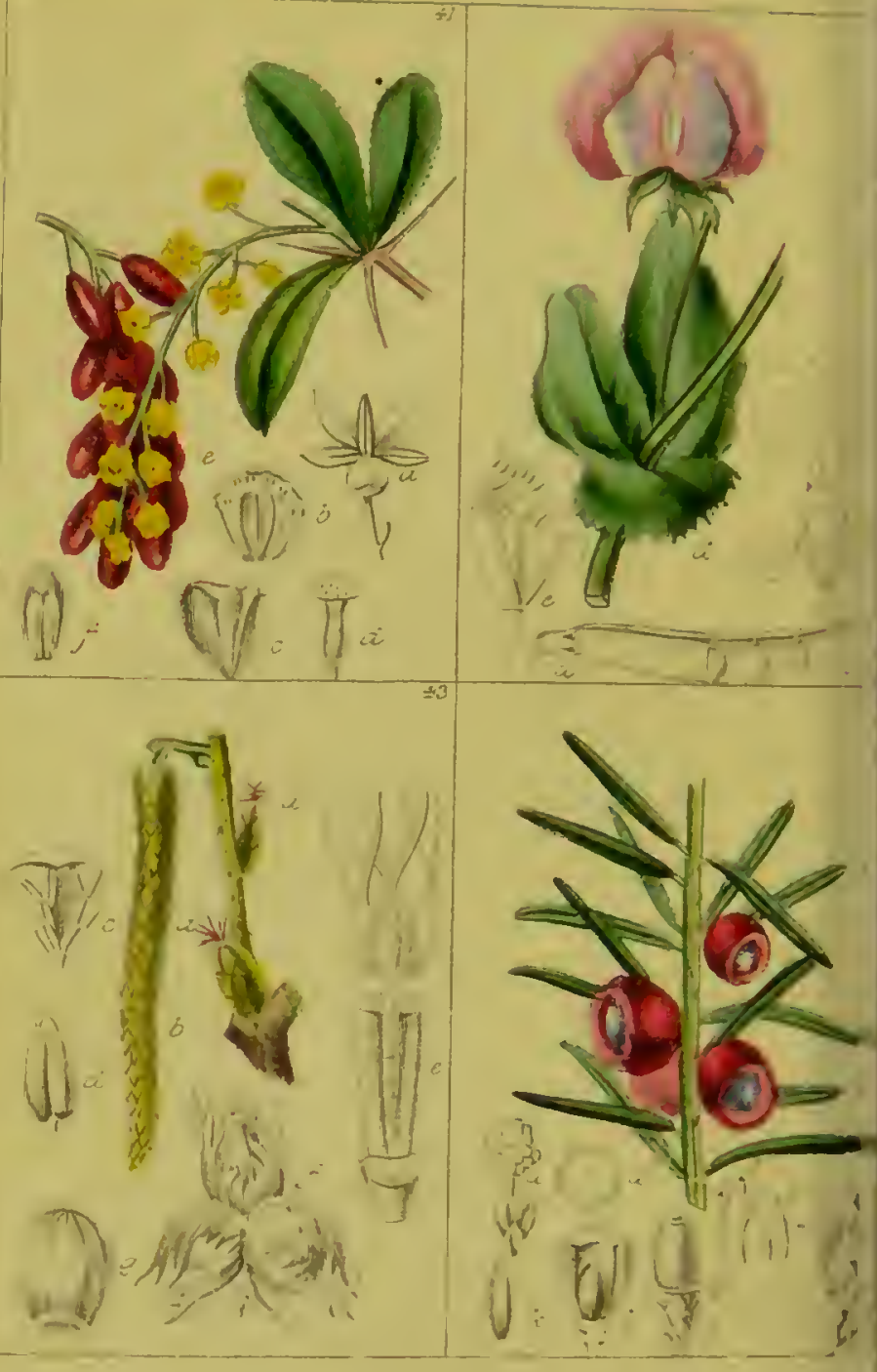



(n)

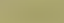


NATURA, SYSTEM.TLRLBATHAE. 311

again subdivided into sub-orders, snb-tribes, and tribes. These sub-divisions, though somewhit distracting to the student by the nutiplicity of distinctions, render the study of the whole in groups easier in the end than if no sub-divisions were designaled. Tliey are like the inarginal lines of counties on a national map; and, by apportioning the uttention, make the exertion less irksome.

It is needless to point to the great number of magnificent plants which are found in this order, for whether we view the open uncultivited commions, or look into the arable fields or pastures, or into the flower or pleasure gardens, we alle sure to encounter some plant or other belouging to leguminosa. We give a figure, $P l .42$, of the field-pea (Pisum arvense); $a$, the calyx; $b$, a lietaclied corolla; $c$, the standard or rexillum; $d$, the alit or wings; $e$, pistils and stanens iu their natural positions, that is diadelphous-nine united ly their fila. inents, and one free, the pistil between the two series; 5 , the legume or pod, one portion removed to show the seed.

\section{TEREBIXTHACE.}

An order not jet definitively itrangred, for want of full information as to the various genera, of which there are twenty-seven. 'They ire all slurubs or trees, with ulternate existipulate leaves, inconspicuons flowers, and abound in a 
balsamiferous rezin, which is chiefly present in the leaves and bark. Some are valuable as medicines, and others for their fruit. The cashew and pistacea nuts are well known in European markets. 'The hog-plum (Spondias) and the mango are favourite tropical fruits. The balsam of Mecca, the balm of Acouchi, the gum of Amyris, the mastich, and Venetian turpentine are all products from the plants of this order. Besides, the frankincense of India and many of the best varnishes are procured from one or other of the genera.

CHAILLETIACEA AXD A QUILARINEA.

The first agrees with the Terebinthacex, in being furnished with a calyx and corolla; fruit furnished with a dry covering, including a two or three-celled nut. The leaves are entire, alternate, and stipulate, with axillary or terminal racemes of small white pentandrous flowers. The nuts are poisonous, and employed to kill rats. The aquilarineæ include only one genus, which is an evergreen shrub or tree found in Malayo.

BRUNIACEE, SAMYDEA, AND HOMALINEA.

Three small orders containing together about a dozen generd. The first are small heath-like plunts, and rery neat both in flower and foliage. Samydex are small slurubs or trees, with leares covered with shining dots, and with small axil- 
linry decnndrous flowers. The Honulinea have polyandrous flowers, nud are handsome evergreen shrubs with alternate leares and deciduous stipula. Blackwellia, one of the genera, has fine bunclies of white and frigrant dodecundrous flowers. Aristotelia is not uncommon in our shrubberries, and bears entable berries, about the size of peas, of a rery dark purple colour, and of an ngreeable acid flavour. plant which Dombey used with so much success against the plague, in Chili, in the year
1782 .

RHAMNE.E AND CELASTMUNEA.

These two orders are somewhat alike in habit; but the first differs from the second in having the stamens alternate with the petals; the sepals imbricated in astivation; and the orarium wholly superior. Celastrus, the stafftree; ilex, the holly; and rhamnus, the buckthorn; are the normal genera of these orders. 'They are all shrubs or small trees, and some of them are common in our gardens, as the staphylen, the celastrus, the ilex, and the euonymus or spindle tree with its curious fruit. 'The fruit and inner bark of the rhamnus catharticus are purgative and emetic. Some, as zizyphuss,
jujuba, yield a wholesome and agreeathle fruit;
and the $Z$. Lotus, of the and the $Z$. Lotus, of the $A$ frican shores of the Mediterranenn, is celebrated to the skies for its
usefulness :- 
SIt NATUIIL SYSTLH.-OTHALAMILORE.

The trees around them all their food produce: Lotus, the name divinc, nectareous juice, 'Thence called Lotol,hagi, which, whoso tastes, Insatiate riots in thcir sweet repasts.

HOMER.

The leaves of rhamnus theezans are used by the lower order of people in China instead of tea; and the leaves of many of the genera are used medicinally.

With these two orders we finish our remarks on the sub-class CALYCEYLOR E, which comprises all plants having their petals separate, and inserted into the calyx; this circumstance being the character of the second sub-cliss of the second sub-division, Dichlamydea.

\section{CLASS III.-THALAMIFLORAE.}

We now enter upon an enumeration of the orders contuined in the third sub-class, Thalamiflora, the chief character of which is, insertion of the stamens under the pistillum. This sub-class contains all the polyandrous plants of Linnæus, as the sub-class calycifloræ, which we have just left, contained all the icosandrous plants of the same Botanist.

This sub-class is divided into four sections, namely, First, fruit inserted into a fleshy receptacle, with which the style is continuous. Second, ovarium solitary, placenta central. Third, carpella solitary or connnte, placenta 
NATURAL SYSTEM.-SIMARUBACEA. 315

pariental. Fourth, carpella numerous, or stalmens opposite the petals. The first order of the first section which we have now to notice is

CORIARIEAE.

Consists of a single genus; the species are astringent, and their leaves, especially those of C. myrtifolia, have been employed by dyers to strike a black colour. Their succulent fruits are, if eaten in any quantity, poisonons. Saurages witnessed death ensue in half an hour after some were eaten. Accidents have happened from the leares of this plant being fraudulently substituted for senna.

\section{OCHNACEAE.}

An order containing four genera, and fifteen species. They ure yellow-flowereid, fragrant tropical shrubs with shining leares, and fruit, which though notvery igreable, is wholesome. The flowers are polyandrous.

These two orders are all that are continined in the first section of this sub-class.

SIMARU BACLE. This small order of three genera is found
in the warnlest parts of Anerica. They are trees or shrubs, with an intensely bitter bark, a milky juice, and pinnated leares. Simaruba and quassin are the two most important genera in- 
cluded in this order; both ure valued for their excessive bitterness, which is pure and simple, and free from astringency and scent. The flowers are decandrous.

\section{RUTACE玉.}

$A$ rather extensive order of herbs, shrubs, and trees, found in all parts of the globe. The rue, and its allies, are bitter stimulating plants, with a strong and rather unpleasant scent, and a hol bitter taste. Rue was much esteemed in ancient medicine, and strongly recommended by Hippocrates, and in a later age by Boerhaave. The African rntaceæ have regular flowers, and are known as diosmas, the European generi, dictamnus, ruta, \&c., have irregular, and more showy blossoms.

\section{ZYGOPHYLLEE.}

This order consists of seven genera, and above thirty species, of which guaiacum is one of the most prized, as well for its medicinal properties, as for its wood, which is known in commerce and in the arts as lignum vitæ.

\section{OXALIDE.E.}

An order of only three genera, but a rast number of species. Oxalis, the wood sorrel, is the type, and a beautiful family of herbs they are. Their properties are well known; all 
NATURAL SYSTEM.-GERANIACEAE. 317

having a slightly acid taste. In some of the American species oxalic acid exists in great abnndince. Averhoa, another genus, are East India fruit trees, and the other, and last genus, is the byophytum, very nearly allied to oxalis.

\section{BALSAMINEX.}

An order containing two genera, namely, balsamina, and impatiens; the last so named because of the elastic force with which the seeds are scattered, if the ripe capsula be ever so gently touched by the fingers. Both orders consist of annuals ; the balsam is a well-known garden ornament, and one of the impatiens is the noli-me-tangere, a British plant. Some Botanists are of opinion, that the three last mentiuned might be all thrown into one.

\section{TROPAOLESE.}

This order contains only the genus troprolum commonly called the Indian cress or nasturtion. They differ from geraniacæ by their stamens being separate, and not agreeing in number with the petals, by their axillary flowers, and
fleshy closed fruit.

\section{GEIANIACEX.}

This order includes the geraniums (crane'sbill), and pelargoniums (stork's-bill), both wellknown genera, and which have been long known under the general name of geraniums; to- 
gether with the erodium (heron's-bill), and two other nearly allied genera, namely, sarcocaulon and monsonia. They are all herbs or undershrubs, with sometimes tuberous roots. The leares are mostly simple, the lower ones opposite, the upper ones alternate, their fellows being supplanted by peduncles as in vines, but these never become tendrils. The facility with which the pelargoniums can be varied in their forms and colours by cross impregnation has multiplied, and is still multiplying varieties without end. $\Lambda$ bove three hundred rarjeties are already catalogued.

\section{AMPELIDACEA.}

This order includes four genera, namely; cissus, umpelopsis, leea, and vitis. This last, the invaluable grape-rine, is the type of the order, and the only one which yields useful fruit. The ampelopsis (virginia creeper) is seen in every court-yard, and the leea and cissus are hot-house plants of no beauty.

\section{MELIACEX.}

This order is particularly distinguished by the stamens being united into a tube bearing the anthers. They have mostly pinnated leares, and are natives of the tropics, being either trees or shrubs. Among other fine trees in this order the mahogany (Swietenia) may be mentioned as giving dignity to the whole. 
NATULAL SYATEM. - HIPPOCASTANEA. 319

SAPINDACEAE.

A large order of gener'a, there being nineteen, and of these, there are eighty-eight species. One of the distinctive pecnliarities of this order, or what is sometimes called the essential charucter, consists in tle petals having an additional lobe in the inside, or a tuft of liairs instead. Nearly all liave compound leares and bunches of white flowers. Euploria nephelium, and dimocirpus, both bear fine lruit, and so do melicoccis; and the arillus of blighia sipida are excellent as desserts. There is only one of the generi which succeeds in the open nir with us, namely, the kölreuteria, a deciduous native of Chiua.

RIIZOBOLE天.

An order containing only a single genus, namely, the caryocar nucilerum, of which there are three species, called by the colonists the butter-nut. In our fruit shops, these fruits Silour.

\section{MIP POCASTANEE.}

This order embraces only the horse-chesinut and pavia ; the first is a well-known ornariental tree; the second is not so frequently seen, but is equally ornamental, having its fine spikes of
scarlet flnwels. 


\section{ACEIRINCAE}

Includes the maples, of which there are nearly thirty species. They are natives of the northern hemisphere, and particularly abundant in America, where great quantities of sugar is manufactured from the sap of the sugar maple (Acer saccharinum), and the ash leaved species, Negundium fraxinifolium.

\section{MALPIGH I ACEE.}

An order of tropical trees and shrubs, some of them climbers. They are known by the stinging hairs by which their leaves are defended, by the undulated corolla, the petals thereof being without claws. The fruit is eatable under the name of the Barbadoes cherry, that of M. glabra is much esteemed in the British West Indies, and on the American continent. The timber of the malpighiacex is of a deep red colour, and their bark is a febrifuge.

\section{ERYTHROXYLEE.}

An order containing only two genera, and four species. Erythroxylon, is its nime implies, is remarkable for the redness of its wood, a charicter likewise occurring in some of the malpighias; but from these they are distinguished, not only by their peculiar habit, but by their appendiculate petals, each laviug a little claw at their base. They are shrubs or 
NATUUAL SISTEM.-GUTTILLE. trees, with ulternate leures, furnished with ax-
illary stipules.

\section{UIPPOCHATEACEA.}

An obscure order in which five genera have been arranged, of which there are thirteen species named in books. They are tropical urborescent or climbing slirubs. The enflorescence is axillary, und in fascicles; the flowers small and regular.

\section{MARCGLATICEA.}

Very curious lalf climbing slirubs, natives of the tropics. The flowers are very large and showy, und some of the species are remarkible for their curious pitcher-slmped bracteic somewhit resembling the ressels formed on the leares and leaf-stallis of cephalotus and nepenthes; and on the same plan as the extraordina'y trap appendages of Dionaca and

Drosera.

GUTTIPER.E.

Trees or shrubs found in the hottest parts of the world. The leares are opposite, leathery, entire, with short petioles, a strong mid-rib, und often parallel hiterul costula extending to we find the garciniu mangostana, or mangostien,
which by universal consent is esteened the 
most delicious fruit in the world. It is as large as a full sized orange crowned with the persistent stigma. The central placenta is less visible than that of an orange, the pulp is beau. tifully transparent, and the flarour exquisitely rich and refreshing, combining the flavour of the grape and strawberry. The African and American mammex bolh yield pleasant and useful fruits and good timber, garcinea gambogia yields the well known and valuable gunresin callcd gamboge so much employed in medicine, and as a pigment. This tree also yields good fruit, which is considered an excellent provocative of the appetite.

\section{HYPERICINEA.}

An order of seven genera and ninety species. The native and hardy exotic sorts which bear the open air in this country are well known; and there is a general resemblance, especially in their leaves being dotted with black, even upon the yellow petals. The petals have also a singular obliquity, which is not visible in their outline, but by the arrangement of their veins. A small part of the order is tropical, but its most conmon habitat is in the shady groves and thickels in the cooler parts of Europe.

AURANTIACEI.

The orange, lemon, citron, shaddock, and 
NATURAL SYSTEM.T-TERNSTROMIACEA. 323

lime family. They are plants of the greatest beauty aud utility. They ure, without exception, innocuous plants, and although formerly exotic rarities, are now, from the excellent, portuble, and keeping qualities of the fruit, as plentiful, and often cheaper than soine of our native fruit.

\section{OLACINEA.}

An obscure orcler of four genera and six species of trees or shrubs, nostly tropical. They have alternate, simple, entire leaves; enflorescence axillury, the flowers snall, unsymmetrical or by abortion polygumous. The place of this order in the natural system is not yet established.

\section{CAMELLIAEIE.}

The Chinese Camellias, and their congener thea or ten, are so well known as to need no description. The first is one of the most beautiful, the last, one of the must useful plants in the world. The seeds of several of the camellias yield a fine oil; though none have fragrant flowers. Some Botanists think these
belung to

\section{TERNSTROMIACES.}

A small order of trees or slirubs bearing white or yellowish flowers. Nothing is known 
of their properties, except from what may be suspected of them as allies of the tea. As ornamental plants they are desirable; and several of them, as the gordonia, stuartia, \&c., are in our shrubberies.

\section{CHLENACEE.}

An order of one genus, the species of which are shrubs or trees, with simple alternate leaves ; natives of Mudagascur.

\section{ELEOCARTEA.}

This is an order of four genera and six species. They difler in nothing from tiliacex, except their lobed petals and anthers opening by two pores at the apex. The flowers of elaocarpus are fragrant, and some of the species bear eatable fruit. The Perim-kara of Malnbar is one of the species, which bears palatable fruit, the stones of which have rough and apparently sculptured surfaces, and are often brought to this country, and set in gold for necklaces.

\section{TILIACEE.}

The linden or lime tree is the type of this order. They are trees or shrubs, seldom herbaceous plants, with simple alternate leaves, and deciduous stipules. The enflorescence axillary or terminal, racemose or paniculate, 
NATURAL SYSTEM,-BONBACEE.

seldom solitary, and the flowers are regular and united. The inner bark of most of these plants is tough and strong, and of which Russian mats ure made. Honey made in the neighbourhood of Lime forests is always considered superior to any other.

\section{BYTTERICEAE.}

This is an extensive order consisting of twenty-eight genera, and above one hundred and fifty species. They consist of lofty umbrageous trees, fine shrubs, and flowering herbs. The seeds of the sterculia and chicha are large and eatable. The astrapaca of Madagascar is one of the most beimtiful of trees. Guazuna ulmifolia has its fruit filled with a pleasant muciluge which is sweet and very agreenble. Several of the genera have properties which are variously useful.

\section{BONBACEA.}

This order comprises a very grand assemblage of trees, with large showy fiowers, mostly natives of the tropics. The adansonia is supposed to be the largest vegetable production in the world. The bombax (the silk-cotton tree) is most splendid when covered, early in spring, with a mantle of rich scarlet blossoms. This order is, in many particulars, allied to 


\section{MALVACE.E.}

An extensive order, containing twenty-two genera, and nearly four hundred species. It includes the well-known mallow (althere), to which the hollyhock belongs; the hibiscus, pavonia, lavatera, malvaviscus, \&c. The greater part of the order is clothed with stellate pubescence; and a kidney-shaped one-celled anther is common to the whole. These two peculiarities, together with the alternate stipulate leaves, distinguish malvacere from all the rest of dichlamyder. The invaluable cotton shrub (yossypium) belongs to this order, and other useful and ornamental plants.

\section{LINE王。}

So entitled, from its containing the linum usitatissimum (the common lint or flax), which is of so much importance to the comfort and cleanliness of mankind. This genus is also desirable, as an ornament in the flower garden; the sparkling blue or white flowers of the species are always attractive.

\section{CARYOPHYLLEX.}

A very extensive order, emloracing twentysix genera, and above five hundred and thirty species, found in all parts of the world. $A$ great proportion are weeds: but the sweet and 
NATURAL SYSTEM,-POLIGALICEE. BST

lovely dianthus is the ralued gem of the order; and from the richest of the dianthus family, the clove, the title of the order is derived.

\section{FRANEENIACEI.}

Is an order of one genus, namely, frankenia, allied to caryophyllea, but distinguished from it by the fruit not having a central separate placentu, but bearing the seeds on the inner margin of the ralves. Besides the genus here numed, two others have been added by M. De Candolle.

\section{PITTUSTORER.}

Small shrubs and trees natives of New Holland and Asiatic islands. The order is distinguished by the imbricate astivation of the sepals and petals; which last, as well as the stamens, are five, and hypogynous; and by its millute embryo.

\section{TREMANDREA}

Contains only one genus, namely, tetratheca; of which there are severul species of neat little heath-like plants, natives of New Holland. The flowers ure octundrous.

\section{POLYGALACEAE.}

This order of milkwort, and its allies, are 
herbaceous or shrubby plants, sometimes with milky juices, and simple entire exstipulate leaves. They are mostly ornamental, and some are possessed of considerable beauty. Their stamens are united in a single body; and their irregular bearded petals are very striking.

DROSERACE.E.

An order of fire genera, and sixteen species of herbaceous plants, inhabitants of marshes in all temperate climales. 'The sundews are remarkable for the great number of glandular hairs with which all parts of their leares are covered. The young leaves are circinnate in vernation, and liave the property of curdling milk.

\section{VIOLARIEA.}

If no other genus than the one which is the type of this order were included in it, the lover of beanty and fragrance could not fail to be partial to the whole. Many are remarkable for their perfume, others for their brilliant colours, and all for their neatness. One of the genera, called alsodia, from its leafyness, is a shrubby violet, a native of Madagascar, which has not yet been introduced into British collections. The viola tricolor (pansies) now vie in beauty and variety with the finest productions of the florist. 
NATURAL SYSTLM.FLACOURTINEA. 329

\section{CISTINER.}

The rock-rose family consists of four genera, and one hundred and eighty-seven species. Some species of cistus, or helianthemum, may be seen in every garden, either of which will give a good iden of the general character. The C. ladaniferus (gum cistus) is a general favoulite; and is remurkible for the benuty and ephemeril character of its flowers.

\section{BIINLE.}

This is a small order, and the genera are neither remarkuble for beauty or use. The bix orellani is chiefly known for producing the seeds called in the shops arnotta, used in dairies for colouring cheese. The species are nearly all tropical.

\section{FLACOURTIANE.E.}

An order of only three genera, namely, ryania, flacourtia, and kiggelaria. The order is remurkable on accoint of the structure of the fruit, to the inner lining of which the seeds are attached upon a branched placenta. 'Their properties, if useful, are unknown; they are all small tropical shrubs or trees. Some of the flacourtias yield eatable fruit; they ure called the Madaguscar plum. 


\section{CAPPARIDEIE.}

Capparis, cleome, and their allies, are herbs, shrubs, or small trees, with aqueous juices; alternate, simple, or palmate leaves, with stipules absent or spinescent. Cratava religiosa is pura-ta-rura of Tahiti : it is there planted in the burial-grounds, and it is supposed to be held sacred to their idols by the natives. From the scent of the fruits of his order, they have been called garlic-pears. Capparis spinosa (the common caper) is well known, from the agreeable condiment which its pickled flower-buds afford. It is cultivated on a great scale in the south of France and Italy, and, when pickled, exported in large quantities.

\section{RESEDACEAE.}

This order, of one genus, has a good many worthless species; there being only two in cultivation; the R. luteola, or woad, used for dying yellow, and the matchless scented mignonette. This genus is separated from cruciferx, on account of its capsules being one-celled, and the stamens being indefinite. Another order, datiscec, difters from the preceding, in having an inferior ovarium, and in the seeds being furnished with albumen. These datiscex are strong, coarse, hardy perennials, sometimes seen in our shrubberies. 
NATURIT SYSTEM.-CRUCIFER.E.

\section{CRUCIIERJ.}

The crucifera includes all those plants which have the four petals of their corolla disposed in the form of a cross. It is a most extensive order, coutaining eighty-eight genera, and seven hundred and sixty-one species. It is divided into five sub-orders, fonnded on the manner inwhich the rulical and the cotyledons are applied to each other, that is, how they are disposed witl respect to each other within the testa of the seed; and these are again subdivided into many tribes. This circumstance may be a constint and very proper mark for apportioning this large cumbrous order into districts, but the signs can only be found by dissecting the seeds, which requires considerable tact.

The diflerent genera of this order are of the grentest importance to mankind, directly and indirectly, as liuman and as cattle lood. As proof we need only mention the single genus brassica, with its numerous species, varieties, and subrarieties, supplying our tables and our stalls with the most wholesome animal and vegetable food in every month of the year. Nor is this order wanting in either beanty, or in fragrance; the stocks (mathiola), and the wall flower, though old, are still luvourites, and inany other handsome, as well as useful plants are found here. The general medicinal property of the order is antiscorbutic. 


\section{IUMARIACEIE.}

The greater part of the Fumariacex are delicate annuals, found in all temperate climates. Several of the genera, corydalis and fumaria, are indigenous in Britain, and several of the same, which are perennials, appear in the flower garden.

\section{PAPAVERACEE.}

The poppies and their allies are well known, their splendid scarlet colours making them as conspicuous in the field and garden as their narcotic powers are known in the apothecary's shop. The flowers are mostly large, and are white and yellow, as well as scarlet. Opium is obtained from P. somniferum, and some other species; it is a necessary of life in Turkey, and among the rich Chinese. Even in England the custom of swallowing it as a cordial is much more general than is publicly known. While the juices of the poppy are powerfully soporific, it is absent from the seeds, which have a nutty flavour; and in some countries are put into soups. The orders which remain to be noticed are in the fourth section of thalamiflorn.

SARACENIE.

Here there is one genus only; the sidesaddle flower, so called, frum its resemblance to 
NITURAL SYSTEM.-HYDROPELTIDEA. 333

that urticle of female equestrianism. The species are four, and lave flowers of various colours. They are found in the swamps of North America, and have heen long in our collections.

\section{NYMPHEACEA}

Are the water-lilies of this and other countries. 'There are four genera, namely, Nelumbium, euryali, nymphaa, nuphar, and to which may be added, Victoria regina, a newly discovered genus in Mexico. 'They are all foreigners, except one of the nynplixas, and one of the nuphars, which are Brilish.

The exotic species are magnificent plants, both in their floating loliage, and large roseshaped red or crimson coloured flowers. These fine plants are frequently flowered in our stores in cisterns of water, as they are all aquatics. The roots of these plants are tubers us large as kidney potatnes, and are a good substitute for them at table. The sacred Egyptian bean of antiquity was no other than the seeds of the Nelumbiun speciosum. The new genus Victoria exceeds all others of the order in size of leaves and flowers, and is an object of great interest at present among collectors.

PONOPIYLLACE. ANN HŸDROPELTIDENE.

Two small orders of North American aquatic herbs. The first is nearly related to nymphan- 


\section{NATURAL SYSTEM.DMENISPEMMACL.J.}

cere on the one hand, and to the herbaceous genera of berberide:e on the other. 'The second order difters from nymphæaceæ in having it definite number of seeds. There are two genera with a single species of each. Both are small floating plants, the properiies of which are unknown.

BERBERIDACEE.

An order containing seven genern and nearly forty species. Berberis is a fine genus, and contains several very ornamental plants. Except nandina, which is a pretty Japanese shrub, the others are small and of no great beauty. Mahonia has pinnated leares, and the flowers though small are elegant. The common barberry is wild all over Europe and North America; and it is said that there are several very fine species in Chili not yet introduced into this country. The fruit of the barberry, as is well-known, are acid and astringent, and are used as a pickle.

We give on $P l .41$, dissections of the flower and fruit of the conmon barberry (Berberis vulgaris) ; $a$, the calyx; $b$, the corolla; $c$, a stamen inserted at the base of a petal; $d$, the pistil ; $e$, the fruit ; $f$, a berry cut vertically to show the position of the seed.

MENISPERMACEA.

The genera associated here are climbing 
NATURAL SYSTEN.-ANNONACEA. $33 j$

shrubs, or perennial herbaceous plants, with alternate, petiolate, and, in general, cordate leaves and small flowers. With the exception of schizandra coccinea, none of them are worth cultivating us ornaments. Cissumpelos is one of the principal genera; the berries of several of the species are useful drugs; the poisonous cocculus Indicus is the fruit of C. suberosus, and though a dangerous fruit, it has been found useful in restoring lost power to palsied limbs. They are all tropical plants.

\section{ANNONACEAE.}

This is rather an important order, from several of the species yielding very fine fruit, spices, bc. They are distinguished from magnoliacea by the ubsence of stipular, and by the structure of their athers and seeds. The fruit of the amnona is in many species highly esteemed, es. pecially that of the cherimoyer, which is said to be the finest liruit in the world uext to the mangosteen. A. muricata is the sour-sop; $\boldsymbol{\Lambda}$. squamosa is the sweet-sop; and other species are the custard apples. Asminia triloba (formerly anona triloba) is sour, and has a foctid scent, but is hardy enough to bear the cold of this country: The dry fruit of annona aromatica and Ethiopica, which latter is the piper Ethiopica of commerce. Xylopea frutescens las an aro. inatic fruit with the flarour of pepper. 
336 NATURAL SYSTEM.-DILLENLACL无.

\section{MAGNOLIACEXE}

Consists of five genera, and of which there are thirty-seven species. The magnolias are highly esteemed ornamental trees and shrubs. The hardy species are natives of North America and the more tender ones natives of China and other parts of Eastern Asia. Tulip-tree is a very significant cognomen for this genus, and their foliage is equahy interesting. The bark of M. glauca is said to be as valuable a medicine as cinchona or Jesnit's bark. Michelia champaca, or tsiampaca of the Malays, who are fond of ornamenting their heads with its orangecoloured flowers, belongs to this order, and also the aniseed-tree, illicium floridanum of the Chinese. Liriodendron, or saddle-leaved-tulip tree of our pleasure-grounds, also belongs to this fine order.

\section{DLLLENIAC CAג。}

This order comprises twelve genera and about thirty species. The type of the order is the dillenia speciosa, a native of India, resplendent with yellow blossoms, rivalling those of magnolia. The genera of this order are closely allied both to the annonacer and magnoliacer, from both of which they are however distinguished by the exstipulate leaves and the quinory arrangement of the floral organs. They are also allied (except for their habit and persistent 
NATURAL SYSTFM.—RINUNCULACE.E. 337 sepals) to rununculacea, which accounts for
theil proximity in the system.

\section{RANUNCULACE.E.}

The frogwort, or crowfoot, and its nllies, are herbaceous, seldom shrubby plunts, with aqueous juices, and round or irregularly ingled stems, alternate petiolate leaves, without stipules, but caul. The butter-cups in our meadows, the anemones in our woods, the adonis in our fields, are all as attractive as tley are common. In the garlen, the lowly hepatica, the glittering ranuneulus, the graceful clenatis, and the gorgeous peony, ale conspicuous. 'Twenty-nine gencra and above six h undred species are already described in the lately published genera, and species plantarum. Thegenera are distributed over avery part of the globe, and wherever they are seen they are admired. And yet amid their gaudy colvinrs dangerous qualities lurk. Some of the crowfoots, the South Ainericun anemones,

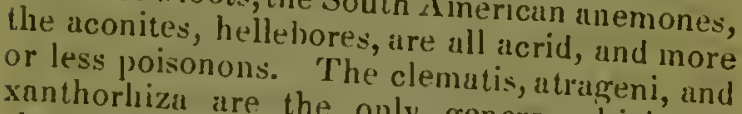
xanthorliza are the only genera wlich are shrubby, and these are embowering climbers, and often employed in covering garden-seats or

The ranunculaceic are the last order of the list section of thesub-class thalamiflore of onr 
338 NATURAL SYSTEM.-CONCLUSION.

arrangement; and from this pre-eminence it would appear that Jussieu and his followers consider this order as one in which vegetation is most perfectly developed, and as presenting the greatest variety of vegetable organization. The characters of this section are carpella numerous, or stamens opposite the petals.

Having ended our review and enumeration of the divisions, classes, subdirisions, and orders of the natural system, it may not be amiss to append a few general inferences deducible from the whole.

And first we may presume that when the student takes a backward glance at the rast array of two hundred and ten orders of rascular plants, and nine orders of those which are cellular, he may well be appalled at the difficulty he will have in attaining even a very moderate knowledge of them. And, as one genus can only be distinguished from another by a close comparison, a large share of practical information is in the first place necessary, before he could be competent to assign to any giren plant its proper place or order in the system, so as to arrive at its name and botunical character. But the study of Botany, like that of erery other science, appears much more difficult and per- 
plexing to the beginner than it afterwards proves to be when the first step has been surmounted. Let us suppose that il tyro is about to connmence the study of the nitural system, who, ufter having well considered the scheme, picks up by accident any morsel of regetable matter, whether alive or dead. By eximining the structure, he may easily determine whether it be cellular or vascular. If the first, he will see it perfectly uniform, as if formed of atoms of equal size and consistence. If the litter, he will observe that the structure is far from uniform, but is vuried by dillerent sized tubes, by fibrous bundles, and by zones of porous or denser substance. Hence he refers the latter to the second division, rasculnres, and the former to the first division, cellulnres.

If, agnin, he has opportunity of seeing a number of young plants just risen from the seeds, some with one seed leaf, or cotyledon, and others with two or more; he may be as. sured that the first belongs to the first class, monocotyledonex, and the last to the second, dicotyledonea. But, supposing he has no opportunity of seeing seedlings rise, he muy exnmine the perfect leaves, for they will furnish hin with as much information as though he had seen the seedlings. If perfect leares have a principal midrib or costn extending from the base to the apex of the leaf, with laternl z. 2 
branches or nerves, the student may be certain that the plant belongs to dicotyledonea, $f .91$. And besides this, if he

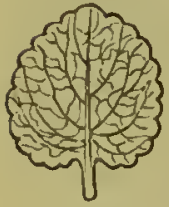

91

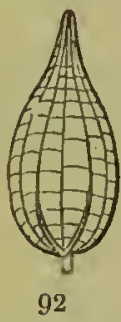
observes that the lateral growth or expansion is added to the exterior of the axis, he maly be equally assured that the plant is dicotyledonous. But if, in eximining a perfect leaf, he finds, instead of a principal midrib, this member divided at the base into several ribs, which rise towards the apex, or to the margin, in nearly parallel or slightly diverging lines, he may be convinced that the plant is monocotyledonous, $f, 92$; and more especially if it be observable that the additions to the bulk arise from the centre, and are not laid upon the outside of the axis.

Here are two very material points gained; and he then proceeds (as there are no subclasses in monocotyledonea) to find out, by actual practice, the characteristics of the subclasses of the third subdivision of dicotyledonea ; that is to say, whether a flower under investigation has got the calyx and corolla distinct, showing the two coats of dichlamrders; or, when these members are united, to show that they have only one coat, which refers to monochlamydea. Next he observes, whether the 
NATURAL SYSTEM.—CONCLUSION. 341

stamens be seated under the pistillum; in which case the flower is thalumiflorous; or calciflorus, seated on the calyx; or corollifiorus,
sented on the corolla.

Ascertaining these points by practice is a great adrance in acquiring $n$ scientific knowledge of plants; and what many will be quite satisfied to attain, even should they be for ever incapable of assigning plants to their orders respectively. But such a ground work will enuble the possessor to gain a knowledge of the orders almost intuitively; and for generic and specific names a master must be applied to who can point out the practical road to is thorough knowledge of this fascinating sci-
ence. 



\section{N D E X.}

Acanthacex, 275. Acclimatation of

Plants, 117. Acerinex, 320. Acotylcdoncs, 210. Alangica, 305. Alburnum, 8. Algac, 217.

Amaranthaceae 270 A maryllidacca, 240 Arucntacex, 142 . Amentacca, 256. Amcrican Aloc, 256.

Armpclidacc $2,318$. Annonacer, 335 . A nomalae, 141 . Antidesmex, 260. Apctalae, 141, 142 . - ct Aflores, 142 - ct Aflorcs et Acarpi, 1.2. Aphyllax, 210. Apocynex, 286. Apple, 83.

Aquilarinex, 312. Araliaca, 299.
Arrangement of

Flowers, 57. Aroidca, 230. Asarine, 262. Asclepiadaccæ, 284 Asli, 288. Asphodclex, 238. Aurantiacex, 322 . Bacca, or berry, 8. . Balsaminea, 317 . Bark, 11 .

- spccial uses of, 17.

Begoniacca, 268.

Berbcridaceae, 334 . Bignoniacea, 283. Bixineze, 329 . Bombaccae, 325 . Boraginca, 280. Bractex, 44 . Branches, 25. Brcxica, 289. Bromeliaccn, 235. Bruniacce, 312 . Buds, 27.

Byttcriacce, 325 . Cactex, 301 .
Calcyoræ, 292. Calycercae, 297. Calyx, 62. Cambium, 10. Cambrianx, 10. Camelliacca, 323. Campaniformes 139 Campanulacex 294 Cannce, 245. Calycan thacex 309 Capparidex, 33».

Caprifoliaceæ, 299 Carpology, 85. Caryophyllei, 140 . Caryophyllen 326. Catkin, 66. Celastrinex, 313. Ccllular Tissue, 4. Ccllularcs, 208. Ccratophylla, 306 . Chaillcticex, 312. Chenopodacea, 268 Chlcnacex, 324 . Cistince, 329. Cloranthca, 298. Cobaraca 283, 281 Collct, 14 . 
Colour of Plants, Dipsacca, 297. 121.

Combretacex. 307 . Commelinacca, 235.

Coriariea, 315. Compound Leaves, 39.

Compositae, 296.

Conifera, 254.

Coirvolvulacere, 281.

Cordiaccre, 280.

Corolla, 67 .

Corolliflorre, 273.

Corona, 73.

Crassulacex, 302.

Cruciterre, 331.

Cruciformes, 139.

Cryptogamia, 197.

Cucurbitacea, 303 .

Cunoniacere, 300.

Cycadacere, 250.

Cyperaceæ, 228.

Cypress, 255.

Cytinex, 261.

Dccandria, 161.

Decay of Plants, 123.

Dcfinition of the Science of Bo. tany, 1 .

Diadelphia, 180.

Diandria, 148.

Dicllamydcx, 273.

Dicotylcrlones, 253

Didy namia, 172 .

Dillenacere, 336 .

Diccix, 192.

Diuscorex, 239.
Disk, 78.

Dodccandria, 164 .

Droscracere, 328.

Drupc, 84.

Ebenacer, 289.

Eleocarpere, 324.

Elm, 258.

Elzeagnex, 262.

Elephant's Foot, 239.

Empetrca, 254.

Englishman's

Foot, 271.

Enneandria, 160.

Epacridacex, 291.

Equisctacea, 223.

Ericacce, 292.

Erythroxylea, 320.

Escalloniere, 300 .

Euphorhiacea, 260

Ficoidene, 301.

Filices, 224.

Flacourtianex, 329

Flosculosi, I 4 I.

Fluviales, 229.

Foliacer, 219.

Foliage, 28.

Folliculus, 84.

Frankeniacer, 327

Fronds, 41 .

Fumariace $2,332$.

Fungi, 210.

Gentianacen, 284.

Geraniacere, 317.

Gcsncrieæ, $29 \%$.

Gilliesicre, 229.

Glands, 54 .

Globularix, 273 .

Goodenovix, 295.
Graminex, 228.

Granatcx, 308.

Grossularica, 300 .

Guttiferæ, 321.

Gynandria, 187.

Hamodoracce,

241.

Haloragcre, 307.

Hamamclidere,

225.

$\mathrm{Hazcl}, 257$.

Hcmerocallidere,

243.

Hcpaticre, 219.

Hcptandria, 157 .

Hermann, 133.

Hexandria, 155.

Hippocastanc $x$,

319.

Hippocrateacca,

321.

History of Botany, 126.

Homalincre, 312.

Husk, 66.

Hydrocliaridacea,

248.

Hydrolcacer, 282.

Hrdropeltidex, 333

Hydropliyllca, 280

Hypericinca, 322.

Hy poxider, 241.

lcosandria, 167.

Infundibulifor.

nes, 139.

Inscrtion of

I.caves, 41.

Involucre, 65 .

Iridaccre, 242.

Iuglandcre, $25 \%$. 
Jasminex, 288.

Juneere, 249.

Jussicu, 203.

Labiatea, 139, 277.

Iaurinea, 266.

Legume, 81 .

Legmillosae, 310 .

Lentibularix, 274 .

Liber, 8.

Liehens, 217.

Lilae, 288.

Liliacei, 110 .

Linere, 326.

Linnzean Classifieation, 144.

Loasea, 303.

Lobeliacex, 295.

Lycopodiacere, 223

Lythrarieene, 306.

Magnoliacex, 336. Malpighiacea, 320 . Malracee, 326 .

Maregraviacex321

Margins of Leaves, 38.

M arsileaec $2,222$.

Medullary Sheath, 8.

Melantliace $2,237$.

Melastomaeere,305

Meliaeex, 318.

Memeeylex, 309 .

Menispermaeex, 33.4 .

Monadelplia, 177.

Monandria, 147.

Monoehlamydex, 253.

Monocotyledones, 227.
Monocotyledo. nous leaf, 29.

Monceia, 189.

Monapetalie, 143.

Morisoll, 132.

Morjuliology, 8 .

Mosses, 220 .

Musacex, 243 .

Musli room, 215.

Myoporinx, 2,6 .

Myristicere, 265 .

Myrsinere, 290.

Myrtacex, 304.

Natural System, 206.

Nutmeg, 265.

Nyetaginex, 270 .

Nymphxacex, 333 .

Oelinaceac, 315.

Oetandria, 158.

Olacinere, 323.

Oleinx, 288.

Onagrarixe, 306 .

Opuntiacea, 301 .

Orehidacea, 246 .

Orobanchea, 275 .

Oxaliden, 316 .

Ovarium, 79 .

Ovulum, 89 .

Palmx, 2:12.

Palins, 201.

Panclanea, 231.

Papavcracex, 332. Papilionueci, 140 , 143 .

Passiflorex, 303

Paronyeliere, 302 .

Pedalinex, 284.

Pencreere, 292.

Pentandria, 153.
Peperacea, 258.

Perianthum, 65.

Personate, 139 .

Pliancrogamia, 209

Pliliadelphea, 305 .

Phytolaceiv, 268.

Pine A plule, $230^{\circ}$.

Pistil, 79.

Pitcher Plant, 31 .

Pith, 7.

Pittosporex, 327 .

Plantaginere, 271 .

Plumbaginea, 273.

Porl, 84.

Podlophyllacere 333

Polemoniacere $\mathbf{2 8 2}$

Polyadelphia, 18:.

Polyandria, 169.

Polygalacex, 327 .

Polygamia, 196.

Polygonacé, 267.

Pontederca, 235 .

Portulacea, 302.

Prickles, 49 .

Primrose, $2 \% 4$.

Prinulacex, 274 .

Privet, 288.

Proteacere, 264.

Pubeseence, $5 \mathrm{~J}$.

Radiati, 141 .

Ralluneulacex 337

Ray, 132.

Receptacle, 88 .

Resedacea, 3:30.

Restiacere, 229.

Reproduetion of

Plants, 93.

Rhamuex, 313.

Rhizobolex, 319.

Rhizophorea, 308. 
Rhubarb, 267. Roots, 20.

Rosacea, 309. Rosacei, 140, 143. Rubiaceæ, 298. Rutacea, 316 . Salicariae, $3 n 6$. Samyder, 312. Santalaceæ, 262. Sap, 109. Sapindacer, 319. Sapotacea, 290. Saraceniæ, 332. Sassafras, 267. Saxifragee, 300. Scales, 52.

Scaly Sheath, 66 . Scars, 56. Scotch Fir, 254. Scrophularínæe,278 Seed Vessels, 83. Semiflosculosi, 141 Sesameæ, 283. Slieath, 66 . Silicula, 84. Sictaminacere, 245. Simarubacea, 315. Simple Leaves, 33. Smilace 238. Solanex, 278. Spines, 48. Stamens, 75 .
Stations of Flow- Thymclcæ, 263. ers, 56.

Stems, 13.

-Functions of, 15. -Appendages of, 18.

Stigma, 81 .

Stings, 50 .

Stipulæ, 42.

Stomata, 55.

Strobile, 84 .

Strychneræ, 288.

Style, 80.

Stylideæ, 295.

Stramonium, 278.

Symplocinere, 291.

Syngenesia, 184.

System of Tournefort, 137.

Systematic Bo.

tany, 135 .

Tamea, 239.

Tamariscineæ 307. Tendril, 46 .

Terebinthaceæ,311

Termination of

Leaves, 38.

Ternstromiaccæ,

323.

Tetradynamia 176 . Tetrandria, 151 .

Thalamiflor 2 , 314.
Tiliacere, 324. Tobacco, 278. Trcmandreæ, 327.

Triandria, 150. Tropæolex, 317. Tulipaceæ, 237. Turneraceæ, 303.

Typhinse, 230. Ulmaceæ, 258. Umbellatæ, 140 . Urticeæ, 259. Vaccineæ, 294. Valerianace, 297. Vascular Tissue, 6 . Vasculares, 208. Vegetable Life, 101.

Vegetable Mem. brane, 3. Venus' Fly-trap, 31.

Verbenacæ, 277. Violariea, 328.

Volva, or Wrapper, $66^{\circ}$

Vochysiaceæ, 308. Wood, 7.

-Functions of, 16. Yew, 255. Zygophyllex, 316 .

Clarke, Printers, Silver Sireet, Falcon Square, Loudon. 


\section{POPULAR WORK ON FLOWERS ;}

PUBLISHED BY ROBERT TYAS, 5O, CHEAPSIDE.

NLW EDITION.-UNIFORI WITH THE BOOK OF BOTANY.

Cloth, gilt edges, priee $6 s$; silk, $7 s .60$.; or moroceo elegant, $8 s .6 d$.

\section{SEN'TIMENT OF FLOWERS;}

BY TUI EDITOR ON "WOODLNND OLEANINGs."

With Twelvc Groups of Flowers, tastefully designed und coloured, of which the Frontispicce to this volume may be considered a specimen.

"In Eastern lands they talk in flowers, And they tell iu a garland their loves and cares: Each blossom that blooins in thelr garden bowers

"A eharming little book. With a dozen of sweet floral coloured plates, it is preeisely the thing for a fair lady's boudoir."-Lit. Gaz.

"The illustrations are prettily drawn, and eoloured witl fidelity to nature; and each little bouquet, whieh to the uninitiated appears but to represent two or three simple flowers, to the skilled in the language of Flora eonveys an appropriate sentiment. The harmony between the qualities of the flowers and the sentiment attaehed to it is in general well made out."-Fent. Mag.

"This is a eharming little book. Engravings of groups of the most beloved, the most popular, and the most poeticul flowers are very neatly and aceurately eoloured, and interspersed witl falleiful and elegant deseriptions and analogies, illustrated by quotations from the wide range of English poetry, and from whatever has been most graeefully and fondly said of those darlings of na-
ture."-Tait's Mag. 


\section{ROBERT TYAS, 5O, CHEAPSIDE.}

In foolscap $8 \mathrm{vo}$, cloth gilt, price $10 \mathrm{~s} .6 \mathrm{~d}$.; or with platcs carefully coloured after nature, and bound in morocco clcgant, $21 s$.

\section{WOODLAND GLEANINGS; A Companion in the zRural radalk.}

By the Author of the "Sentiment of Ftowers." With Sixty-four beautiful Illustrations.

"This is a swect, pretty volume, full of agrecable miscellaneous literature and pleasing anccdotes. It dcscribes all our Forest Trees, and has an engraving of cach, mingling together history, fancy, poetry, and botany, in a manner at ouce highly picturesque and instructive. The prints arc almost as numerous as the leaves on trccs, and very tastefully executed."-Lit. Gaz.

"A handsome volume, which we havc pleasure in rccommending. "No trec in all the grove but has its charms,' says the title-page, and the asscrtion is abundantly proved by the lettcr-press descriptions, and the pretty engravings (which are numerous). The descriptions are coneise and spirited, the quotations well chosen, aud the book quite a trcasure equally to the idlc and the morc scientific lover of the country." - Court Journal.

"This volume seems well calculated to supply what had becomc a desidcratum; a pocket companion for thosc who, unacquainted with the principles and practice of botany, ret feel an interest in Trees, and might wish to identify such trees as they mect iu their rambles with the accounts they have read of them, or to link the individual trec which presented itself before them with any passagc iu some favourite bard. For either purpose the Wool)LAND GLEAnings will be found an eligible manual."Loudon's Magazine of Natural History.

On the opposile page is a specimen of the illustrations which adorn this elegant volume. 


\section{SPECIMEN}

\section{OP TIE \\ Ellustrations of Cetoodlañ Gileanings.}

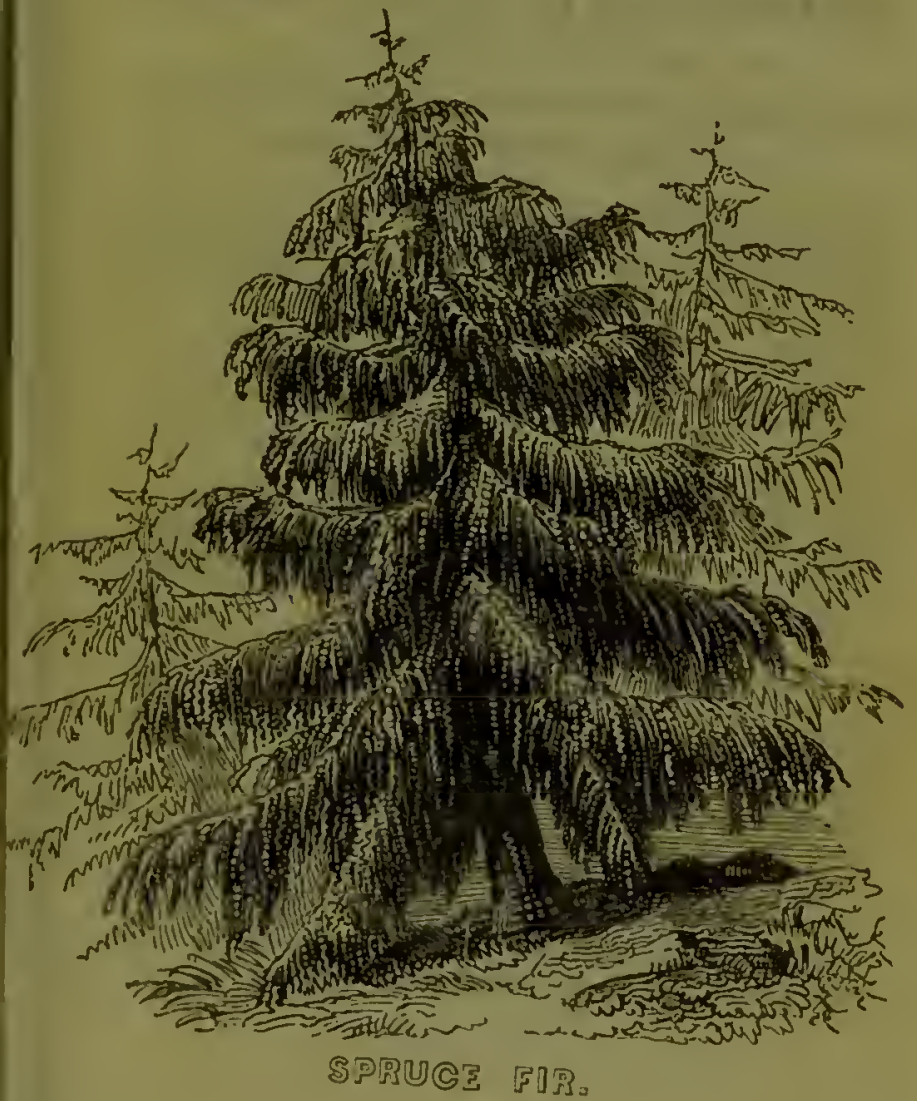




\section{NEW AND POPULAR WORKS,}

PUBLISIIED BY

\section{ROBERTTYAS, 50 , CHEAPSIDE.}

\section{HAND-BOOKS FOR THE MILLION !} Price One Shilling each, in cloth, gilt edges.

\section{THE ANGLER'S HAND-BOOK;}

A complete guide to the Art, with descriptions and coloured figures of Artificial Flies.

THE WHIST-PLAYER'S HAND-BOOK;

Containing Rules and Dircctions for playing the uni versally popular Game of Whist ; Laws of the Game, \&c. \&c. By a member of a Club.

\section{THE CRICKETER'S HAND-BOOK;}

With Directions for Batting, \&c. \&c. All the Laws of the Game, with an Engraved Frontispiece, being a view of Lord's Cricket Ground, showing the respective positions of the Players.

\section{THE SWIMMER'S HAND-BOOK;}

Wherein are many valuablc Precepts, which if the Reader strictly follow, he will soon become an expcrt swimmer. With Fight Illustrations.

\section{SHORT HINTS ON SHORT HAND;}

By which the Student may specdily acquirc a combcteut knowledge of this politc and uscful accomplish. ment. With Four Plates.

** Several others, on popular subjects, are in course of preparation. 


\section{NEW AND POPULAR WORKS,}

PUBLISIIED BY

ROBERT TYAS, 50, CHEAPSIDE.

VALUABLE PRESENT FOR ONE GUINEA!

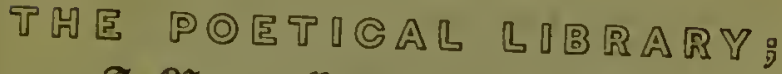

A ftorocen Case with Gilass fromt ;

Containing six volumes lrandsomely bound in silk, comprising Geas PROM BRITISI POETS, viz :-

1.- CHAUCER TO GOLDSMITH.

11.-FALCONER TO CAMPBELL.

III.-LIVING AUTHORS-CHIEFLY.

IV.-SACRED POETRY.

V.-SHAKSPEARE, AND

VI.-CEMS FROM AMERICAN POETS.

${ }_{*}^{*}$ * This Case may also he had with the volumes uniformly bound in cloth, price $18 \mathrm{~s}$.; or in moroeco,
elegant, $27 s$.

\section{THE CONTRAST;}

The 政istorp of a onap-a Tale for Youth). BY W. A NDERSON, ESQ., Illustrated with Wood-cuts, square, eloth 1s. $6 d$. "A very pretty little book for young ehildren, in which the writer eontrasts a day of instruetion, pleasure, of truaney, mischicf, and a good, with the same period -Literary Gazette. 
In royal $32 \mathrm{mo}$, cloth, $3 s .$, or, silk, $4 s$.

\section{G E M S O F P I E T Y; sclected from (Christian æautijars, \\ AND}

INTENDED AS HINTS FOR REFLECTION.

With a beautifully cngraved Frontispiece of the "MIan of Sorrows," after the cclebrated painting of Guido.

"Here we can carry about with us some of the niost precious 'Gems' which adorn the works of the most emincnt servants of the Redeemer. The volume is alike enriched with the eloquence of Chrysostom, and with the superabundant fulness and deep flow of piety of Jeremy Taylor."-Christiun Remembruncer.

Second Edition 12mo, in clotl, price $2 s .6 d$. CAPPER'S SOUTH AUSTRALIA.

Containing Hints to Emigrants; Proceedings of the South Australian Company'; a variety of useful and anthentic information; a map of thc Eastcrn coast of Gulf St. Vincent, and a plan of Adclaide. By H. Capper, senior clerk to the Colonization Commissioncrs.

\section{WOODLAND RAMBZES:}

Or, Uncle Ben's Conversations witlı his Ncphew, on the beanty and utility of Trecs, during a series of pedcstrian cxcursions through the Woodland. Illustrated by many Engravings. 
. 

order no 70 $81=145$ 




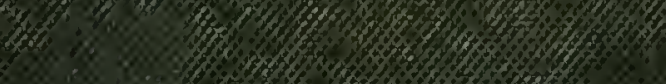

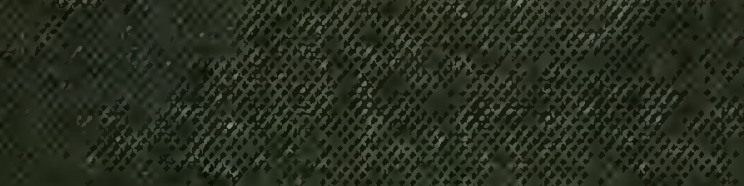

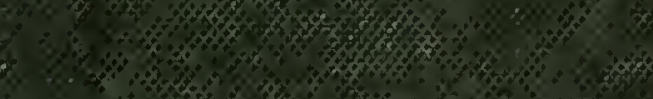

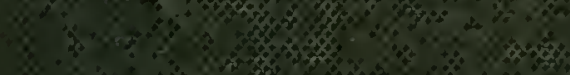

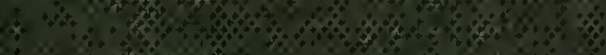

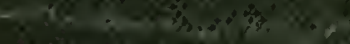
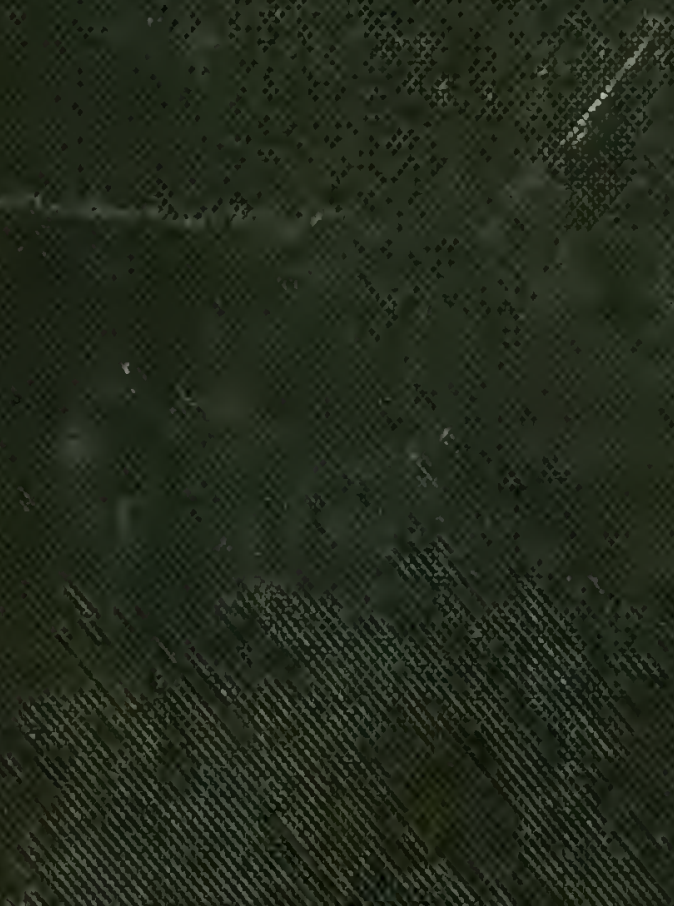